SHEEP FARMING IN AMERICA

JosEPH E.WING 

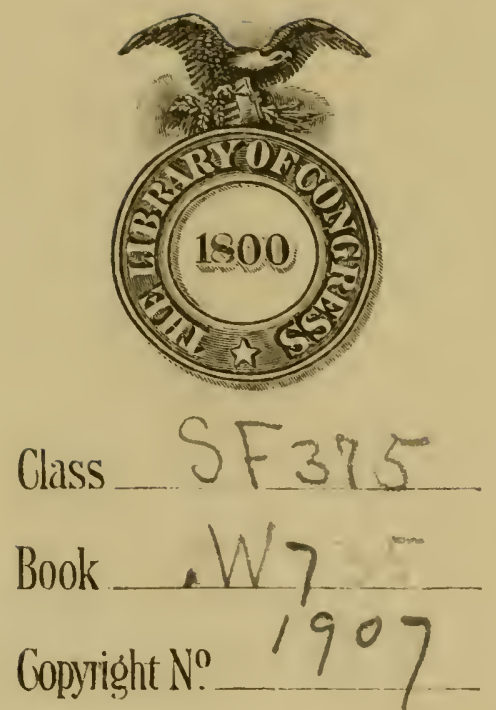
COPYRIGIIT DEPOSIT. 
gosepte W Wing Nor. 1. 1911 




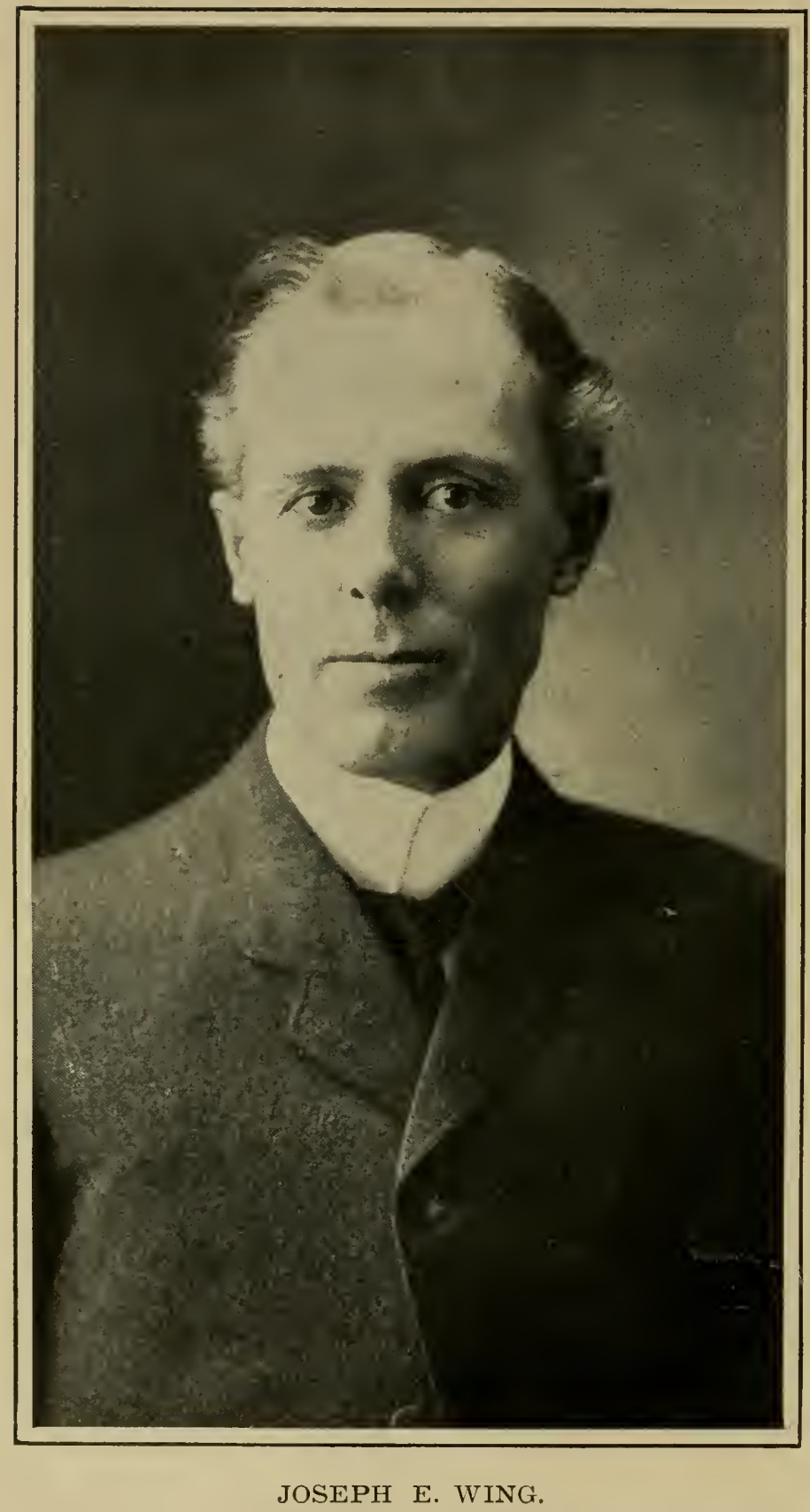




\section{Sheep Farming In America.}

\section{-}

By JOSEPH E. WING,

Staff Correspondent of The Breeder's Gazette.

-

NEW AND REVISED EDITION.

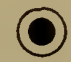

$$
\text { : } \therefore \text {. }
$$

CHICAGO, ILL.:

Sanders Publishing Co. 1907. 


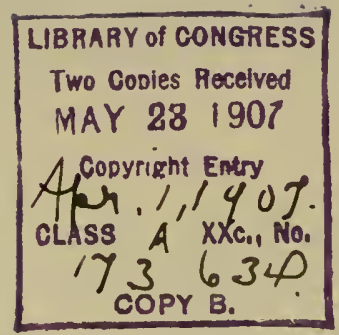

Copyright, 190\%,

BY SANDERS PUBLISHING CO.

All rights reserved. 


\section{CONTENTS.}

ILLUSTRATIONS. .............................

INTRODUCTION. . . . . . . . . . . . . . . . . . . . . . . . . 13-19

Introddction to Second Enition, . . $\ldots \ldots \ldots \ldots \ldots \ldots \ldots \ldots$

\section{CHAPTER I.}

Fine-Wool Breed . . . . . . . . . . . . . . . . . . . . . . 21-31

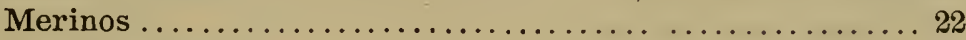

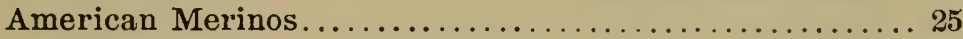

Delaine Merinos and Black Tops................... 25

Rambouillets................................ 26

\section{CHAPTER II.}

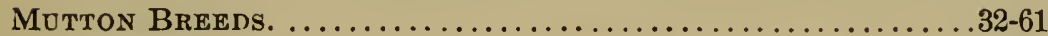

The Downs-

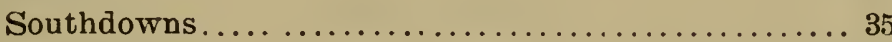

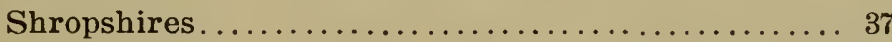

Hampshires........................... 40

Oxfords...............................41

The Long-Wools-

Leicesters............................. 42

Cotswolds............................. 45

Lincolns........................... 45

Dorset Horns. ......................... 46

The Mountain Breeds-

Cheviots . . . . . . . . . . . . . . . . . . . . . . 49

Black-faces.......................... 50

Tunis and Persian Sheep ................. 55

\section{CHAPTER III.}

Cross-Breeding. . . . . . . . . . . . . . . . . . . . . . . 63-71

Cross-Breeding for the Lamb Market.............667

Cross-Breeding in Eastern Pastures................. 69 


\section{CHAPTER IV.}

Selection and Mayagenent..........................

Restocking a Farm with Sheep ................... 72

Selection of the Ram.......................... $\boldsymbol{7}_{4}$

Keeping a Type..............................

Fixing Type .............................. 82

Renewed Vitality from Fresh Blood................ 86

Vitality the Thing to Strive for.................. 87

Selection of the Ewes......................... 88

Getting Home with the Flock..................... 90

Importance of Dipping .......................... 90

The Scab Germ ............................... 91

The Dipping Vat........................... 93

Regular Dipping of the Farm Flock............... 95

Summary of Dipping......................... 98

Fall Treatment of the Ewe Flock................ 97

Mating..................................... 98

Putting in the Ram........................... 100

Management of the Ram.........................100

Care of the Pregnant Ewe.......................103

\section{CHAPTER V.}

Care of the Ewe and Young Lamb................10 7 - 150

The Ewe Barn. . . . . . . . . . . . . . . . . . . . . . . 10

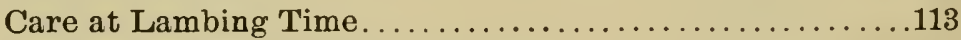

Feeding of the Ewe After Lambing..................118

Troubles of Young Lambhood. . . . . . . . . . . . . . 122

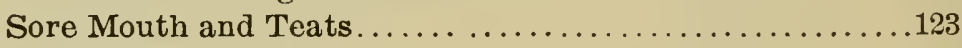

Feeding the Lambs ............................. 124

Feeding for the Market........................... 128

Dressing Lambs for Fancy Winter Market... . . . . . . . 135

Treatment of the Late-born Lambs . . . . . . . . . . . . . . . 138

Feeding Corn on Grass. . . . . . . . . . . . . . . . . . . . 141

Summer Shade..............................142

Marketing the Spring Lamb.................. 146

Docking...................................

Castration of Old Rams............................

Castration of Lambs...........................

Weaning. ................................. 


\section{CHAPTER VI.}

Summer Cale and Managemext. . . . . . . . . . . . . 151-190

The Ewe Flock.............................. 151

A System of Management that Insures a Healthv Flock. . 159

Use of Sown Pastures............................. 168

Oats and Alfalfa Pasture.........................

Clover and Alfalfa Pasture.......................

Danger from Clover and Alfalfa Pasture..............173

The Use of Rape...........................

Cabbages..................................... . . . .

Pumpkins...................................... 180

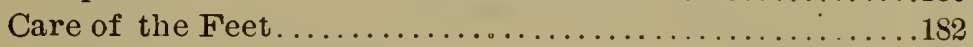

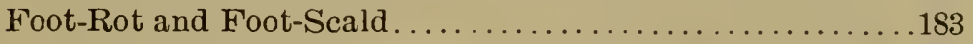

Advent of Late Lambs. . . . . . . . . . . . . . . . . . . . . . 185

The Lambing Tent . . . . . . . . . . . . . . . . . . . 186

Fall Lambs ................................. 188

\section{CHAPTER VII.}

Washing, Shearing and Marking. . . . . . . . . . . . . 191-205

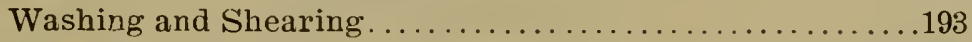

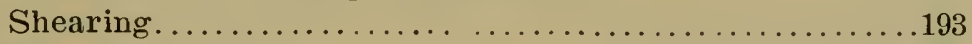

Shearing Machines.............................. 195

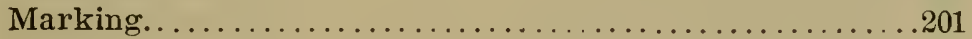

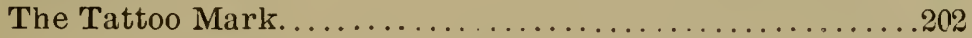

Marking Pure-bred Lambs.......................203

\section{CHAPTER VIII.}

Flock Husbandry in tue Western States. . . . . . . . . 206-255

New Mexico................................206

Characteristics of Mexican Sheep.................20\%

"The Good Old Times" in New Mexico ... . . . . . . . . . . . 209

Modern Management............................210

Diseases of the Range.........................213

Mexican Lambs as Feeders . . . . . . . . . . . . . . . . . . . 214

The Wandering Herds. . . . . . . . . . . . . . . . . . . . 215

Waiting for Grass to Come. . . . . . . . . . . . . . . . . 216

The Blood of the Fierds.........................218

The Division of the Ranges....................... 218

Montana, Wyoming and the Dak tas...............219

Parasitic Infection of the Ranges. . . . . . . . . . . . . . 220 
Happy Future of the Region...................220

Management of the Range Rams.................. .223

Where the Rams Come From.................... 224

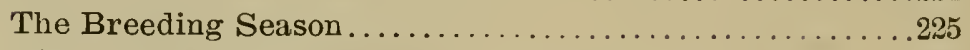

Vigor of Ewes and Lambs........................ 225

The Busy Shepherd at Lambing Time...............226

The Coyote..................................226

"Trimming" the Lambs . . . . . . . . . . . . . . . . . . . . . .228

Shearing on the Range.........................230

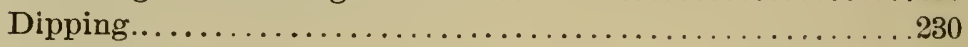

The Maligned "Sheep Herder ". . . . . . . . . . . . . . . . . .232

Ups and Downs of the Business....................234

The Hopeful Outlook. . . . . . . . . . . . . . . . . . . . . 235

A Work to be Done.............................237

Sheep Advance; Cattle Retreat....................238

Winter Feeding of Sheep and Lambs.................238

Necessity for Dipping...........................241

Selection of Feeders..........................243

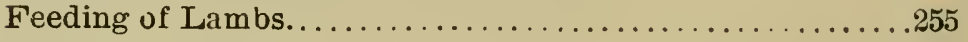

\section{CHAPTER IX.}

Western Lamb Feeding . . . . . . . . . . . . . . . . . . 256-307

Pea Feeding in Colorado........................256

Canadian Peas for Lamb Feeding. . . . . . . . . . . . . . 257

Peas in the San Luis Valley ...................... 258

Amount of Lamb Mutton from au Acre of Peas. . . . . . . . . .262

Alfalfa-fed Colorado Lambs. . . . . . . . . . . . . . . . . . . 264

Feeding Mill Screenings.........................

Sheep-Feeding in the Corn-Belt. . . . . . . . . . . . . . 272

Use of Self-Feeders . . . . . . . . . . . . . . . . . . . . . . .291

Feeding Beet Pulp. . . . . . . . . . . . . . . . . . . . . . . .292

Causes of Death in the Feed-Lot. . . . . . . . . . . . . . 295

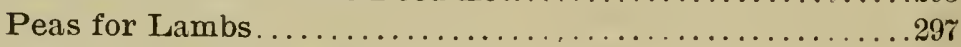

The Business of Lamb Feeding. . . . . . . . . . . . . . .297

Feeding of Older Sheep ........................ 298

Feeding Mature Wethers.........................298

\section{CHAPTER X.}

The Diseases of Sheep . . . . . . . . . . . . . . . . . 308-342

Ailments in General................................ 
Importance of Post-Mortem Dissection ............... 314

Other Diseases of Sheep...........................315

Garget, or Mammitis ............................... 316

Grubs in the Head. ............................... 319

Liver Fluke-"The Rot". ......................... 320

Nodular Disease .................................... 321

Tape Worms......................................

Husk, Hoose, or Parasitic Bronchitis..................323

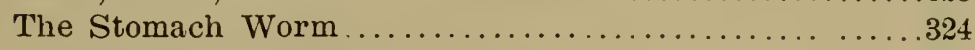

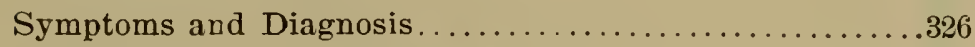

Life History of the Stomach Worm. ..................327

Methods of Preventing Infection..................... 329

Treatment for Stomach Worms.......................334

Coal-Tar Creosote....................................

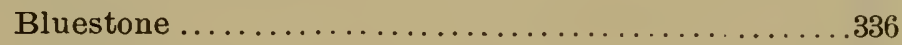

Gasoline ....................................387

Other Remedies..............................387

Start with a Healthy Flock.....................338

\section{CHAPTER XI.}

The Angora and Milking Goats . . . . . . . . . . . . . 343-361

The Angora Goat . . . . . . . . . . . . . . . . . . . . . 343

The Milking Goat.......................... 



\section{ILLUSTRATIONS.}

Joseph E. Wing Frontispiece.

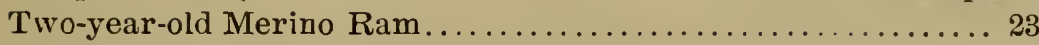

Yearling Rambouillet Ewes in France................ 27

Photographic Studies in Down Types of Sheep........... 33

Farm Training for the Show Ring.................. 38

Lincoln Rams............................... 43

Lincoln Erres................................. 43

Some Ohio Dorsets ............................ 47

Cheviot Ewes............................... 53

Group of Tunis Sheep on an Ohio Farm .............. 57

A Trio of Prize-Winning Lincolns................... 61

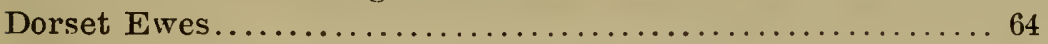

Dipping Sheep at the University of Wisconsin.......... 73

Dipping Plant............................. 75

The Champion Ram that was Not Too Good............. 79

Rambouillet $\operatorname{Ram} . . \ldots \ldots \ldots \ldots \ldots \ldots \ldots \ldots \ldots \ldots \ldots \ldots \ldots$

Shropshire Ewes on a Canadian Farm... . . . . . . . . . 83

Black-faced Rams............................ 85

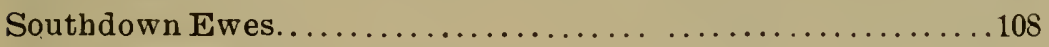

Delaine-Merino Ram Lambs ...........................111

A Bunch of Nebraska Leicesters....................... . . . . .

"Mary Had Five Little Lambs" . . . . . . . . . . . . . . . . . . . . 125

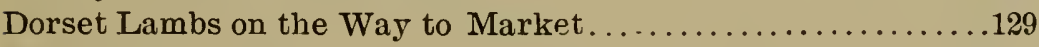

An English "Creep"............................ 134

Ready for Market.................................. 136

Merinos Posed for a Picture..........................139

A Carload of Yearling Wethers.... . . . . . . . . . . . . . 143

In an Old Country Pasture............................. 153

Cotswold Ewes. . . . . . . . . . . . . . . . . . . . . . . . . 157

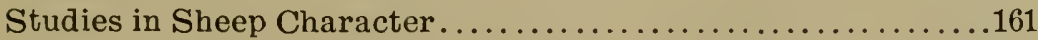

Feeding Lambs on a Hillside Pasture. . . . . . . . . . . . . . . . . 169

Yearling Oxford Ram .............................

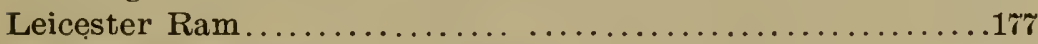

Imported Hampshire Ram Lambs................... 187 


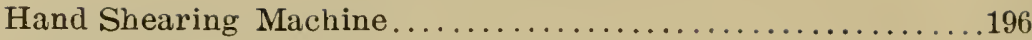

Shearing Black-faced Sheep in Scotland.................. 199

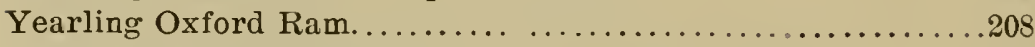

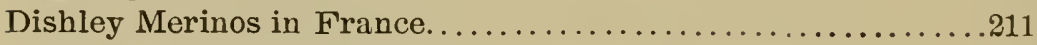

Black-faced Sheep in the Hills ...........................

A Kansas Feeding Yarả, Capacity 18,000 Sheep.............221

A Sheep Wagon on the Range.... . . . . . . . . . . . . . . .22t

Lincoln Shearlings..............................229

An Illinois Feeding and Shipping Yard................231

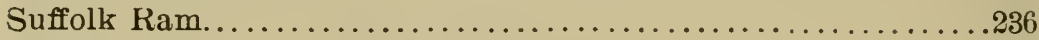

A Fine-wooled Flock on a Western Farm ................239

Feeding Corral, with Straight Fence .................. 245

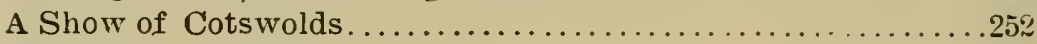

Shropshire Feeders in Colorado......................

Racks for Feeding Grain. ...........................266

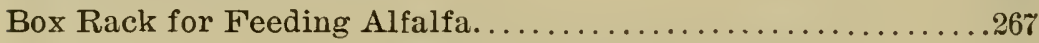

Cross-section of Model Sheep Barn Showing Frame..........273

Side View of Model Sheep Barn Showing Doors . . . . . . . . 274

Two Views of Feed Rack...........................

Feeding Corral, with Zigzag Fence....................281

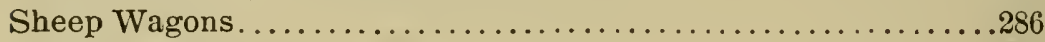

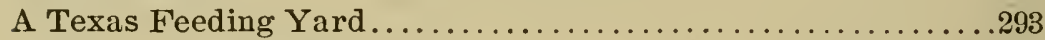

A Pair of Hampshire Lambs.......................... 300

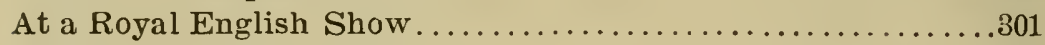

Lincolns in the Show Ring. . . . . . . . . . . . . . . . 305

An Angora Goat Show . . . . . . . . . . . . . . . . . 345 


\section{INTRODUCTION.}

The traveler in England, Scotland and parts of France and Germany is impressed by the importance of the sheep industry to these lands. Sheep farms are often found close together and of large size with great numbers of sheep thereon. 'The writer' has stood on one hill in Dorsetshire and counted eight shepherds, each with his flock of about 400 ewes and their lambs, in sight at one time. Nearby, in an adjoining county, flocks of Hampshires exist as large as 2,500 on farms of not above 1,400 acres of not extra soil. These flocks are very profitable and they make rich soils that without the sheep would be hardly worth cultivating. They exist in wonderful health and vigor on lands that have been sheeped since civilization peopled the land. In Scotland and the Cheviot hills flocks exist over the entire land and without sheep the land would almost lapse into wilderness. In France on lands worth $\$ 250.00$ per acre great flocks of mutton sheep are kept. The agriculture of these countries leans strongly on the sheep. Long experience in maintaining fertility, in creating it, has taught the farmers that without the flocks they can not continue profitable agriculture. Sheep fit in well to an intensive system of agriculture. They are docile, 
tractable, easily kept within bounds, not fastidions in their appetites but willing to devour most weeds along with the good forage, and ther leare behind them a wake of fruitful soil.

In America sheep farming is little understood. Sheep are kept in a more or less desultory manner, having the rum of some hill pasture or woodland, fed at intervals in winter, sold off when prices become low, bought up again with the return of higher prices, given small care or encouragement, often afflicted with parasites, internal and external, a side issue with the farmer, profitable in spite of his neglect, yet not often assuming the dignity of a business of themselves. There are several reasons for this state. It is in part a heritage of the days when sheep were little valued for their flesh and were kept mainly for their fleeces. It is in part a result of our once cheap lands and insufficient labor with which to till them. And in large part it is because of ignorance of profitable methods. When sheep thrive their owners gladly reap the profits; when they become diseased and unprofitable it is usually charged to "bad luck." There need be small element of luck or chance in sheep management. There is always a reason for thrift and for unthrift in the flock. There need rarely be any disease in the flock. A healthy sheep is certain to be a profitable one.

There is at this time good reason for thinking seriously of these problems of sheep husbandry because of the increase in mutton consumption and the curious parallel fact that the production is decreasing. April 1, 1903, 
saw about 39,204,(000 sheep shorn; April, 1904, about $: 38,34^{\circ}, 000$, or nearly a million less. It is probable that this decrease has been checked, though there has been no decided change in conditions and comparatively little re-stocking of Eastern farms. Sheep are essentially today dwellers of the range, the mountain and the desert. Montana has the largest number of sheep, 5,576,000; Wyoming has 3,800,000; New Mexico, $3,150,(0) 0$; Idaho, $2,300,000$; Ohio, $2,033,-$ nou; Utah, 2,025,000; Oregon, 2,000,000 ; California, 1,625,000; Texas, 1,440,000; Colorado, 1,300,000; Michigan, 1,200,000; Pennsylvania, 850,000 ; New York, 675,000; Washington, 560,000 ; Nevada, 600,000; Arizona, 620,000; Indiana, 700,000 , and all other states below 600,000 each. It will be seen that in comparison with the ranges the states make rather a small showing in the sheep industry, Ohio and Michigan excepted. The fact of free grass upon the Western ranges and the general healthfulness of flocks in that arid region have had a deterring influence upon the sheep industry in the old farming states. Now, however, that the ranges seem unable to supply the mutton that is demanded by our consumers it is time to forget their menace and to take up again our old trade of shepherding on our Eastern farms.

There are several excellent reasons why this is a rational and promising industry in which to embark. The ranges are now fully stocked with cattle and sheep. To increase the number's of sheep means to drive out more cattle and this the cattle men are resisting by armed 
force. On many of the drier ranges the sheep have overpastured the grass till much of it has been destroyed root and branch and thus its carrying power is much decreased. Settlers are taking the land in every irrigable valley and fencing it and there is thus in every way a steady diminution in the numbers of sheep on the ranges. Nor can it be seen how this may be checked and their numbers made to increase, seeing that alfalfa forms almost the sole forage grown in the arid region, and this is not a crop suited to careless grazing of large bands of sheep by hireling herders.

Consider again that the prejudice that at one time existed against mutton eating has almost died away. The cities are eating all the mutton that they can get and are paying for it much more than they are paying for beef or pork. There are doubtless several excellent reasons for this. Fashion is one. The fact that crowds of our people visit England every year leads them to form the "lamb chop" habit. Mutton is better fattened and prepared than formerly. There is offered a very much greater supply of lamb mutton than of mutton from old sheep, and that helps. Then the old-time type of small, wrinkly, thin-fleshed sheep has about disappeared and that helps. There is a demand for lambs from babyhood up to a year of age, well fattened; there is demand for mature mutton. Whether the packers have or have not controlled the price of beef they have not been able or desirous of keeping down the price of mutton. For ten years feeders of lambs have prospered 
exceedingly, with occasional discouragements, and there is no prospect of the production of good, well-finished mutton being overdone for some years to come. It can not be overdone until one of two things happens, either the American people must come into calamitous days or a great number of farmers must turn shepherds and learn the business from the ground up. Neither of these things will happen soon. Sheep husbandry is not difficult but it requires close attention to details and that we will not many of us give. The few who will patiently learn the art will therefore prosper the more exceedingly.

It is a cheerful thought to look forward to the day when well kept, happy flocks will abound in our land. Then weeds will disappear to be replaced by luxuriant grass and forage crops. Then trim fields, each with its appropriate green growth, will be dotted with snowy-fleeced ewes and plump, rollicking lambs, each one a picture of health and thrift; shepherds' neat cottages will shelter an intelligent and thrifty class of farm laborers, great piles of manure will be accumulated in winter time to replenish the old fields, the farm boys will find enough to do and sufficient encouragement for doing it and will remain on the farms and then agriculture will be truly an upbuilding, a creation of fertility and farms where now there is little of profit left to country dwellers.

Let no one imagine, however, that these blessings follow the mere fact of buying a flock and placing it upon the farm. "Sheep are ever an unhappy flock,' remarked an old Roman agri- 
culturist, and in no other stock can the ignorant or heedless farmer have so great a variety of misfortunes as with the sheep. Few of these troubles are unavoidable. It is to point the way to success and to indicate the rough places that this little book is written.

It is to be regretted that a great change has come over country life. The old intimacy between the farmer and his men, the farmer and his fields, the farmer and his animals, has to an extent gone, perhaps forever. Nevertheless, the farmer who undertakes to keep sheep with profit must go back to the ways of his fathers and his boyhood, he must cultivate an acquaintance with the individuals in his flock, must learn to know instantly by sight whether or no they are in health, must have their confidence so that he can without much trouble catch them afield, by aid of the shepherd's crook or a bit of salt or a handful of shelled corn. Fortunately this intimacy is a delight as well as a source of profit. "The eye of the Master fattens the flock." Hired shepherds may be faithful, but they need the suggestions and the inspiration that come from wise co-operation of the employer. Best of all shepherds are the men who own the sheep. It is a delightful occupation and one that interests the young. There is room for labor, for thought, for growth in this work. Some of the happiest hours and most helpful the author has ever known have been spent in working among his ewes and lambs, or seated beneath a tree watching them 
graze in the cool of the evening or seeing the lambs scamper up and down the hillsides.

Strong men have come from tending sheep. Young David watched his father's flocks and in his zeal slew the lion and the bear that would have destroyed them. Gazing from his hill ranges afar out over the land he learned to love it well, so that the day came when he emerged from the solitude of the sheep pastures to be the one who should redeem Israel from bondage. Let us hope that in our own times young men may be found who while working with the gentle ewes and innocent lambs may from these scenes of peace absorb sufficient love of home, country and native land that they may come forth strong to help in the redemption and upbuilding of their own country. 


\section{INTRODUCTION TO SECOND EDITION.}

Since this book was first put out a good deal has been learned concerning practical sheep management. The problem of the internal parasite, that terror that devastated eastern flocks, has been nearly solved, and the author has had the pleasure of presenting in this second edition a plan of flock management that will surely avoid the disasters that follow in the trail of the insiduous foe and insure keeping a flock in beautiful health and vigor.

Of a life somewhat filled with work and thought, the writer feels that this is his chief fruit and it cheers him to think that perhaps he may be able to cause fine, healthy, happy flocks to grow where none grow now, or, worse, where sickly and unhappy sheep are.

Of a multitude of friends the writer feels that the ones nearest his heart are the grave and careful shepherds who, loving their flocks better than their ease, make little lambs to grow and play, unafraid, who lead their sheep safely and feed them wisely, and who themselves are led by their life of solicitous care nearer the good Shepherd of us all. 


\section{CHAPTER I.}

\section{THE FINE-WOOL BREEDS.}

It is not thought worth while to present here extensive accounts of the various breeds of sheep; however, some mention must be made of the characteristics pertaining to each. Breeds originate from environment, from peculiar characters of soil and vegetation and climate, and from the mental idiosyncrasies of the breeders themselves. Each breed has its own particular field where it serves best a certain purpose. For all that, breeds are somewhat flexible and several have a wide range of adaptability. Conditions of market and of environment make some breeds more profitable than others in certain locations. What would pay best on the range, in some remote state where wool by its cheap transportation brings the major share of profit, might not pay so well in near proximity to large cities where the demand is for quick-maturing mutton. Inversely, sheep are not suited to range conditions that are not good shearers, good to "herd," that is, having the mental trait that makes them stay close together and an ability to withstand occasional times of starvation. On the farm the ability to live through 
hard winters on sparse allowance of food is not a qualification worth taking into account.

\section{MERINO SHEEP.}

Probably the oldest races of domesticated sheep are the various families of Merinos. Most they have felt the moulding hand of man, most they seem to diverge from any wild type of which we have knowledge. Very likely Merinos were kept in Palestine during bible times and it may be that King David when a lad watched beside a flock of Merinos. Under the hand of man they have suffered a degeneration in form, not being as hardy, as vigorous or full of stamina as any wild race of sheep now in existence. What they have lost in form and vigor they have gained in fleece. The wool of the Merino is the finest and for many purposes easily the best in the world. It should command the highest price and usually does. Merino breeder's in the Eastern states, however, must compete with producers of wool in remote and semi-savage lands, Australia, Argentina, Patagonia, the Falkland Islands and parts of our own great West.

Breeders of Merino sheep have followed many fashions and some that were their undoing. At one time the aim was to secure a fleece of extreme fineness, though by this course was secured a sheep of little stamina and of small value for mutton production. Again the aim sought was an excessive amount of oil or "yolk" in the fleece, which made it heavier. This weakened the sheep, made it sensitive to cold weather 
and, curiously enough, as the weight of yolk increased in the wool, manufacturers kept apace of the fact in buying, and by paying for it on a scoured basis there was nothing at all gained to the grower who sold the excessive amount of grease. A manufacturer once related to the writer how in the palmy days of heavy fleeces a

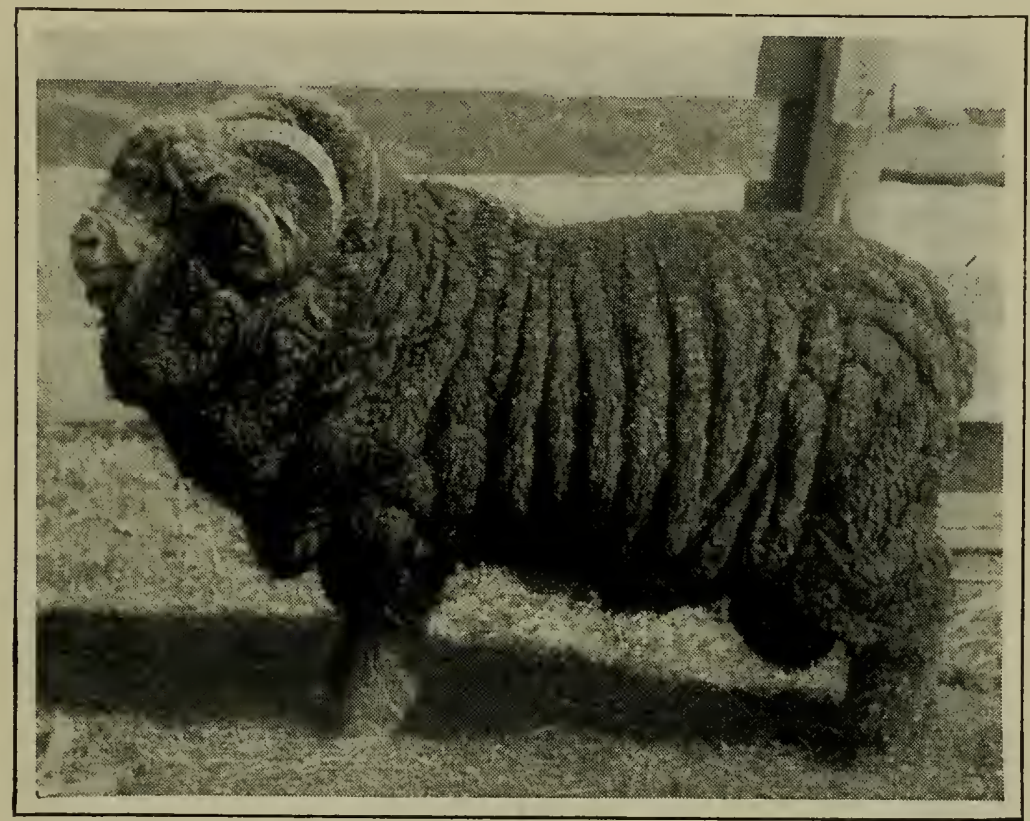

TWO-YEAR-OLD MERINO RAM.

celebrated ram's fleece was brought to him to be scoured; it weighed 45 lbs., was probably of 18 or 24 months' growth and made less than $12 \mathrm{lbs}$. of scoured wool! The farmer then had wasted food enough to produce more than $30 \mathrm{lbs}$. of a product of no utility whatever; in fact, being only a drain on the strength of the animal that 
produced it. It is of course essential that wool should have a sufficient amount of this yolk to preserve the fiber; more than this is a damage in every way.

It would seem that now the fads in Merino sheep have nearly disappeared and the breeders at the present time are breeding useful Merinos, with generally more size and better forms and more of mutton quality than was once seen.

The importance of the Merino breed will be recognized when it is remembered that about $22,000,000$ of the sheep of the United States are of Merino foundation. The Merino is the sheep of the range country, hardy in large herds, of long life, though of slow maturity, able to withstand more of "grief" than the mutton breeds, and, most important to the ranchmen, holding their fleeces to quite an age, whereas under range conditions mutton breeds soon become light shearers. However, it is not now believed among Western ranchmen that the Merino should be bred pure for their purpose. They use large numbers of mutton rams and aim to keep in all their ewes a strain of mutton blood, from $1 / 4$ to $1 / 2$, which they find makes the ewes better mothers, being more prolific and having a stronger milk flow. Lambs from such ewes, sometimes from pure-bred mutton rams, form the major part of the supplies received in our great markets from August till June. A flock of ewes from Merino mothers and a good sire of one of the mutton breeds are almost ideal for use upon the farm, hardy, healthy, great milkers, good shearers. When again topped by a blocky, mutton- 
bred sire they produce lambs that are hard to excel.

\section{AMERICAN MERINOS.}

There are a number of families of Merinos. The American breeder's divide them into three general classes - the Spanish or American Merino, the smallest in size and heaviest in fleece of any; these sheep were once excessively wrinkled (wool grows upon wrinkles, thus the woolbearing capacity is increased). They usually have a considerable amount of yolk in the wool, though by no means the excessive amount that was once common. During recent years the American Merino has undergone quite an evolution, obedient to the command of its breeders, and has a better developed leg, a stronger back, a better sprung rib, more vigor and stamina than before and has, I think, lost little in fleece-bearing powers.

The American Merinos are the most highly specialized of all sheep, their wool being best and most abundant. Their breeders do not claim that they are mutton sheep, though they do make good mutton; but not so profitably as some lighter shearing breeds.

\section{DELAINE MERINOS AND BLACK TOPS.}

These two families have been bred by selection from the original Spanish; the Black Tops from the importation of 1802 , the Delaines from the Black Top foundation, with some outcrosses of other Merino blood. The idea in developing these two families has been to secure a larger sheep than the original Merino, a better feeder, a 
hardier sheep and with a "Delaine" wool. This wool should have parallel fiber's of sufficient length for combing purposes. There is unquestionable merit in these sheep and in the hands of some breeders they approach closely to the mutton type without losing their valuable fleeces. Delaines are hardy, healthy when rightly managed, their lambs from mutton sires are superior for the market and a well managed flock of either Delaines or Black Tops has never been unprofitable. The name "Black Top" was given by the originator of the type because his best sheep had a dark crust on the outside of the fleece composed of oil and dirt this crust keeping out weather and serving to shelter the sheep. It is doubtful, however, if sheep should be required to carry shelter from rain on their backs.

\section{RAMBOUILLETS.}

Nearly two centuries ago the French government began importing Merino ewes from Spain and then was laid the foundation of the breed that is called the "French Merino," or "Rambouillet," after the village in France where the stud flock has been kept. With different feeds, different ideals and selection, the breed has become quite different from the other families of Merinos, having much greater size and a different type of wool, with coarser fiber, though yet a Merino wool.

The Rambouillet is perhaps the most popular today of all the Merinos, great numbers being found on the Western ranges where there are also great breeding establishments. Here thou- 


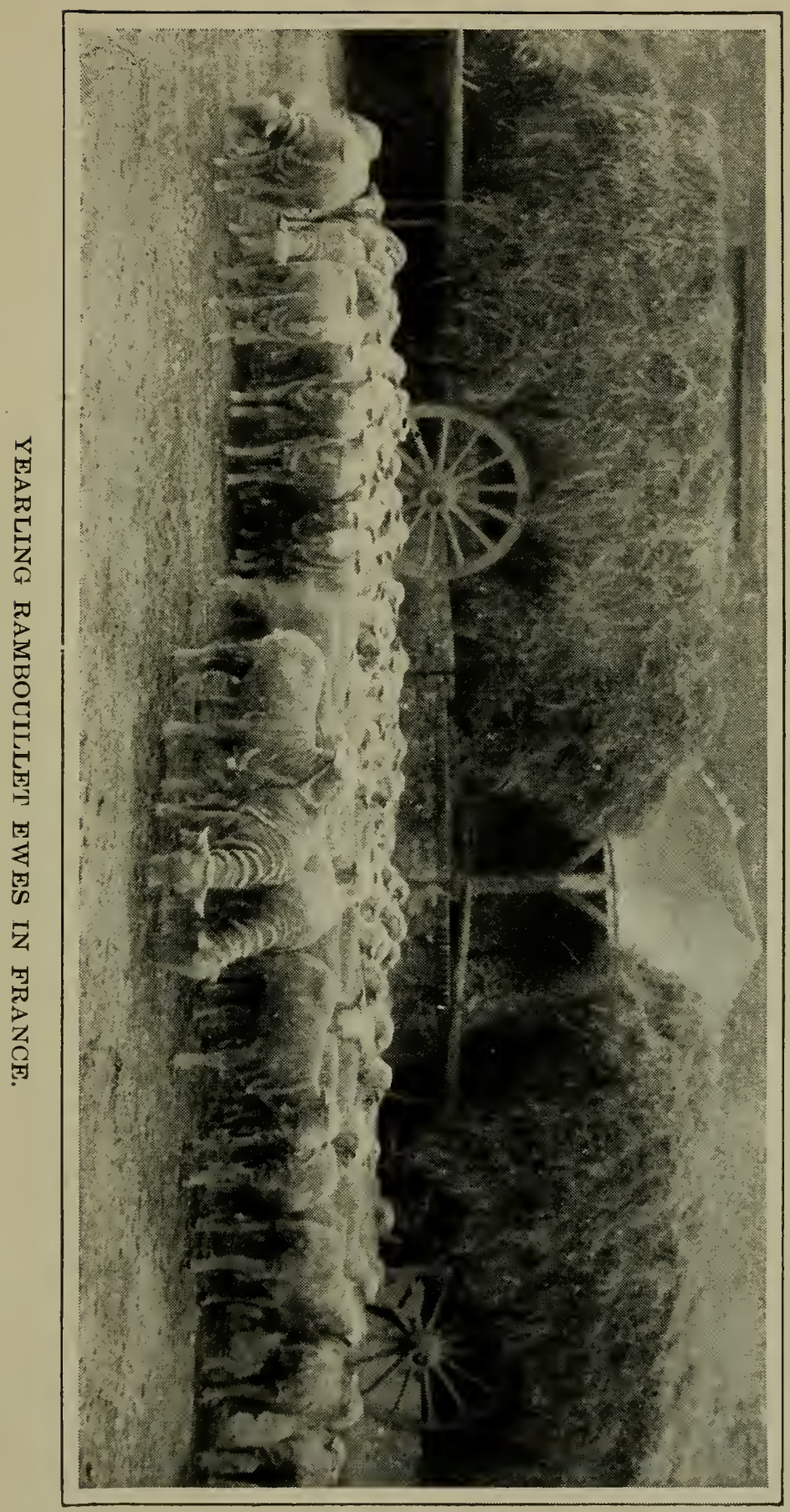


sands of pure-bred rams are grown. Fashions change even on the ranges and at present there is inquiry for Delaines, and many rams of mixed Delaine and Rambouillet blood are used, besides some with an infusion of the blood of the American Merino. Rambouillets are truly wonderful sheep, of great size and unlimited capacity to consume food. With a top of mutton rams they produce great lambs or make superb wethers.

Rambouillets have been grown profitably for 50 years in Ohio. There are indeed some farms that have been stocked with these sheep continuously for that length of time, which is unusual in America. In recent years the breed has been considerably improved by fresh importations and by careful matings, so that both form and fleece are better than formerly. The Eastern Rambouillet growers have for some years enjoyed a very profitable trade in rams which they have sent to the Western ranges. However, the large Western breeders are absorbing much of that trade of late, so that only the choicest rams are in demand for Western shipments. A good flock of Rambouillets will pay for their wool and mutton, and Rambouillet ewes make a most admirable basis for a cross-bred flock.

Rambouillet and Delaine Merino ewes have the ability to conceive early and drop their lambs in the fall or winter. Many Rambouillet breeders make a practice of lambing as many of their ewes as possible in the fall and early winter months, thus getting the young things forward to a good state of growth and development before spring and summer come to bring their 
problems of management. The early lamb is often worth double the late one, because of the superior healthfulness and vigor of the early born that escape the troubles of parasitism, so distressing to those of late birth.

This habit of early yeaning also comes in good hand when the Merino ewes are used as mothers for cross-bred "hot house" lambs, and many growers of these winter lambs use Merino mother's though the half-blood Merino ewe is better. In truth she is near to perfection for this purpose.

It is a curious fact that many old men succeed fairly well with Merinos who can not make mutton sheep thrive at all. The Merino will withstand more neglect than the English breeds. It will endure fairly well a winter ration of bright straw and a little added grain with the run of a hill pasture. Formerly thousands were wintered on pasture with no feeding at all throughout the hill regions of Ohio and Pennsylvania. It was thought that if they had access to hazel brush where they might shelter and browse a little and the grass was not too closely cropped in fall they would do well enough. Treated in this manner they must lamb late in the spring, and they do survive and shear quite good fleeces, whereas any breed of mutton sheep, so poorly fed would hardly show any profit at all.

It is often quite difficult for men who have spent years of their lives growing Merinos under the let-alone, outdoor system to take another breed and make it thrive at all. They can not 
bring themselves to give the feed, shelter and attention that the English breeds demand. And with Merinos, kindness and care are usually well repaid. There are hill regions where the flock may be out of doors almost the whole year, but the grazing should be supplemented by a regular allowance of grain or early-cut hay, and it is well if the flock can be sheltered from chilling winter's rains. 


\section{CHAPTER II.}

\section{MUTTON BREEDS.}

All of our breeds excepting the Merinos and the Tunis come from England. There the peculiar character of the country and the mental traits of the people have united to create a number of breeds, each having its especial excellence for a certain purpose and soil. The Englishman's ideal in animal form runs, as it does in architecture, to the square, the level, the rectangular. His sheep, his beef cattle and his swine all partake of the same characteristics in form. To successfully judge Merino sheep one must be a student of the breed; to judge the mutton breeds practically well one need only to know what is a good animal, after the model of the Angus cow or the Berkshire hog. Add the wool and certain fancy points, such as the covering of wool over the head, the size and set of ear, the shape of nose and the coloring and all is told. The novice in sheep breeding, if he knows Angus cattle or Berkshire or Poland-China swine, need have no hesitation in attempting to select a flock of breeding erres if he can see them without their fleeces. In fact, the owner will betray his consternation before the novice has selected 


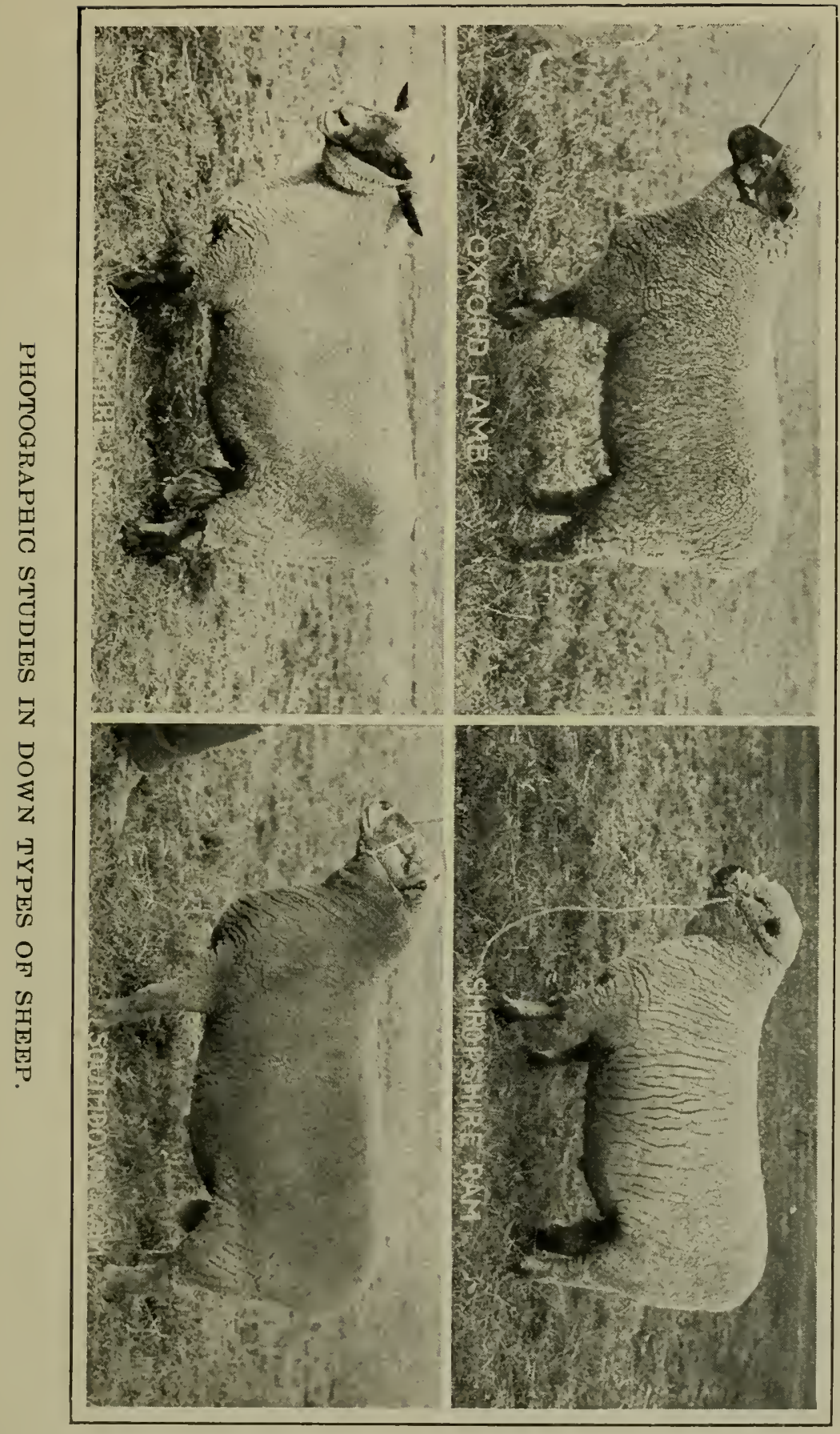



half a dozen and remark, "You may not know much about sheep but I can't let you select from my flock."

The English breeds are naturally divided into classes of Downs, Long-Wools and Mountain breeds.

\section{THE DOWNS.}

In the south of England is a chain of chalky hills, covered with fine, short grass. Since history began there has been on these hills a race of short-wooled sheep; in their early history, with horns. From this old type has come the Southdown, the Hampshire Down, the Sussex, Oxford, Shropshire Downs and the Dorset horned.

\section{SOUTHDOWNS.}

This sheep is a striking illustration of what the genius of man can do. Before the day of George the Third the unimproved Downs of Sussex were "of small size and bad shape, long in neck, low at both ends, light in shoulder, narrow at the fore end, and shaped like a soda water bottle, small in front and heavier in the middle; large of bone, but boasting a big leg of mutton. The fleece was not so close and firm as now."

Once the Southdown was horned but now there is seldom a scur to remind you of the past. Today the breed is one of the most perfectly formed breeds in existence. The size is but medium to small, but so compact and thickfleshed are these sheep and so close to the ground that their weights astonish those who are unacquainted with the breed. The Southdown has 
a straight back, a thick, muscular neck, bespeaking vitality, a well sprung rib, giving a rotundity of form and a well filled leg of mutton. The character of the mutton is of the best, being finegrained, well marbled with fat and lean and tender, sweet and juicy. The wool is short, thick, elastic, of excellent quality, though not so abundant as in some breeds. Southdowns are very vigorous, hardy, ambitious, good foragers, good feeders, always fat if given opportunity, more easily kept in health than some breeds and the rams are excellent for cross breeding, especially where early lambs are desired.

There are not so many breeders of Southdowns in America as the merit of the breed would deserve. It is one of the easiest of all breeds to maintain in high-class condition. There is little tendency toward deterioration, though there is great difficulty in bringing about change or improvement in type. This is no doubt owing in part to the fact that the breed is absolutely pure, no admixture or infusion of other blood having ever taken place. Therefore, there is less variation of type and it is easier to have a flock of Southdowns of uniform appearance and character than of most breeds.

In Sussex the author has studied Southdown management on their native sod and observed these features of their practice. Dry ewes in summer time were often grazed on the hill pastures, but under the care and observation of shepherds at least part of every day. Ewes suckling lambs were in hurdles eating sowed crops of clovers, vetches and grass, with a little 
bite of grain, while the lambs "ran forward" in other hurdle-enclosed bits of grazing. As protection against sun the lambs had small squares of canvas stretched over the corners of their pen. The lambs got a full allowance of "corn and cake;"' that is, grain with broken linseed oil cake which is much fed in that country and seldom ground into meal. The lambs were as fat and round as little pigs and were sold as they ripened, week by week, on the London market. Of this system of hurdle grazing we will speak later at more length.

There are few breeds with more adaptability than the Southdown. It is especially useful on high-priced land and near markets that demand fancy lamb mutton. Though a Southdown flock will not shear so much as some others of the Down family it is questionable whether there is a more profitable breed for the production of fat lambs to be marketed either from their mothers' side in late spring or early summer or to be fed later and marketed at the age of eight to ten months. Their smaller size is in their favor, seeing that small and very perfect lambs well finished, command a premium always. Southdown ewes are prolific and excellent mothers, and the lambs are strong at birth.

\section{SHROPSHIRES.}

Farther to the north in England originated the Shropshire sheep. Not unlike many pastures of our country are those about Shrewsbury, affording strong grass, based upon lime- 
stone and clay loams. The Shropshire had its origin in a mingling of the bloods of a native black or brown-faced and horned sheep called from its habitat the "Morfe Common sheep." They were small and bore light fleeces of not more than $2 \mathrm{lbs}$. Infusion of Leicester, Cotswold and Southdown blood worked a great change, practically obliterating the blood of the earlier parents and bringing at first great diversity of type. Careful selection toward a pretty

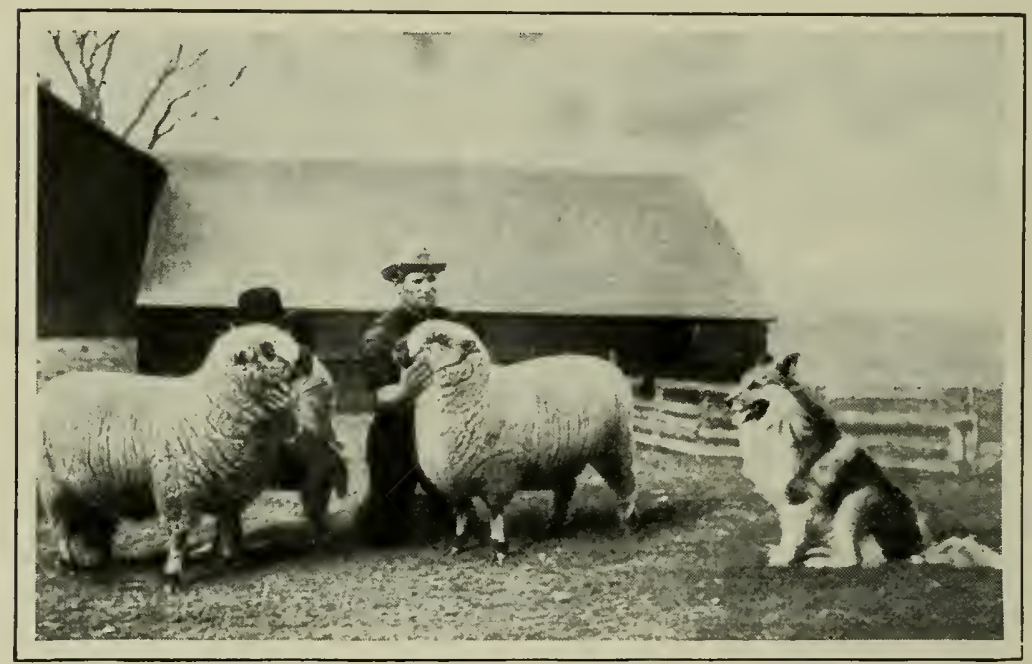

FARM TRAINING FOR THE SHOW-RING.

well defined ideal had by 1853 resulted in fixing a type and it was then advised that the Royal Agricultural Society recognize them as a distinct breed. Since that time they have gone steadily forward in improvement and this is especially notable in recent years, when the breed 
seems really to have reached its ultimate perfection. It would certainly be difficult to suggest any desirable modification of the well bred Shropshire's form, fleece or character. The breed is perhaps the most popular in the world today and has the largest number of registering breeders.

The Shropshire is a medium-sized sheep, rams weighing from 175 to $225 \mathrm{lbs}$. and ewes 125 to $170 \mathrm{lbs}$. They shear well, considerably better than the Southdown, and the wool is of excellent quality. The lambs fatten well and should go to market from their mother's sides, else they may reach too great weights for the top of the market.

The Shropshire ideal in form is close to that of the Southdown, with a little greater size and a darker head and legs, though not so dark as the Hampshire or Oxford Downs. The fleece is longer than in the Southdown and is not usually so close-set or dense. Certainly there is no more beautiful sight than a well bred and well kept flock of Shropshires, the fine matronly ewes with their white fleeces set off by the brown of heads, ears and legs. Their mutton is perhaps not quite so good as the Southdown, but there is not much difference in this respect, and they are equally prolific, though the lambs may not have quite the same vigor at birth nor do they usually fatten at quite so early an age.

The one difficulty with the Shropshire sheep in America is the careless and ignorant shepherd who permits his flock to become infested with parasites or allows his ewes to become so 
fat that they do not breed well, and such a man might not succeed with any breed.

HAMPSHIRES.

'The study of how this great breed was originated is a most interesting one, though rather too long and complicated to be entered fully into here. The Hampshire is the result of skillful mingling of the bloods of an old white-faced horned race, called the Wiltshire, the Southdown, the Sussex and probably the Cotswold breeds. During many years men worked gradually toward an ideal, making skillful matings and discarding the inferior offspring as well as those which went toward the wrong type. The result was astonishing, for the Hampshire breeds now remarkably true to type and that type quite unlike any of the ancestry involved in its creation.

The Hampshire is the largest and heaviest of the Down breeds, and is only excelled by the Lincoln in weight and occasionally by the Cotswold, among the long-wooled races. It has dark brown or black points, with bold countenance, and a large ear, set on rather low and standing well out to the side. The bone is large, limbs especially strong and well set on; fleece fine and white. It presents a very striking appearance, the rams having bold Roman countenances, and the ewes characteristic strong but feminine faces.

The Hampshire is essentially the sheep for the arable farm, fitted by long habit to being put in hurdles, able to consume a large amount of 
food and to make from it good mutton at an early age. The Hampshire lamb is famed for its early maturity and great weight. There is no breed that excels the Hampshire in this respect. Well kept Hampshires are among the most profitable sheep in the world.

The writer recalls with great pleasure some days spent in the Hampshire growing country of England. It was much of it a soil of only moderate fertility, resting on chalk, the farms of fairly good size. One especially of 1,400 acres he recalls to mind, for on that farm were 2,500 magnificent Hampshire sheep and lambs. Most of them were in hurdles and following the hurdles were seen great crops of grain.

There seemed to be not a single sheep or lamb on this farm that was not in perfect health and vigor.

A man ambitious to do the best possible thing with sheep can take up the Hampshire breed with good courage, for they have in them possibilities in the way of great and rapid growth beyond most breeds; perhaps beyond any other breed. On the other hand few breeds degenerate into more unsightly "weeds" than badly kept and diseased Hampshires. The Hampshire ram is often used for cross breeding and gets fine, vigorous lambs nicely marked with black points.

\section{OXFORDS.}

The Oxford is in appearance a large Shropshire, with a coarser and more open fleece, a larger bone, usually a darker face and coarser ear. It is the result of crossing the Cotswold 
and Hampshire types, begun about the year 1833. The Oxford is a noble sheep, having some of the characteristics of the Hampshires; is a good sire with which to cross breed and is often used for that purpose. There is need of a little more care in management with these sheep to avoid parasitism than with some breeds, but no man who has grown Oxfords and kept them healthy but has found them profitable.

\section{THE LONG-WOOLS.}

\section{LEICESTERS.}

The Leicester is an old breed little known in the United States at the present time but much kept in Canada. It is notable as being the first recorded sheep to feel the improvement of a genius in breeding, Robert Bakewell having undertaken the improvement of the breed in about 1755. Bakewell conceived the idea of improving this old, coar'se-boned, long-wooled breed. Just how he did it we would like to know and never will, but it was entirely by selection, so we are told, and he evidently had the master eye for seeing virtues in animals and knowing which would be transmitted. He made such fame as a breeder of sheep that before his death his rams were let for the season for as high as $\$ 2,000$ each.

The Leicester is found in Canada and on some of our Western ranches. It is a large sheep, with white points and a long, rather coarse wool. It is finely formed, with an especially wide spread of rib, and has an extraordinary facility 


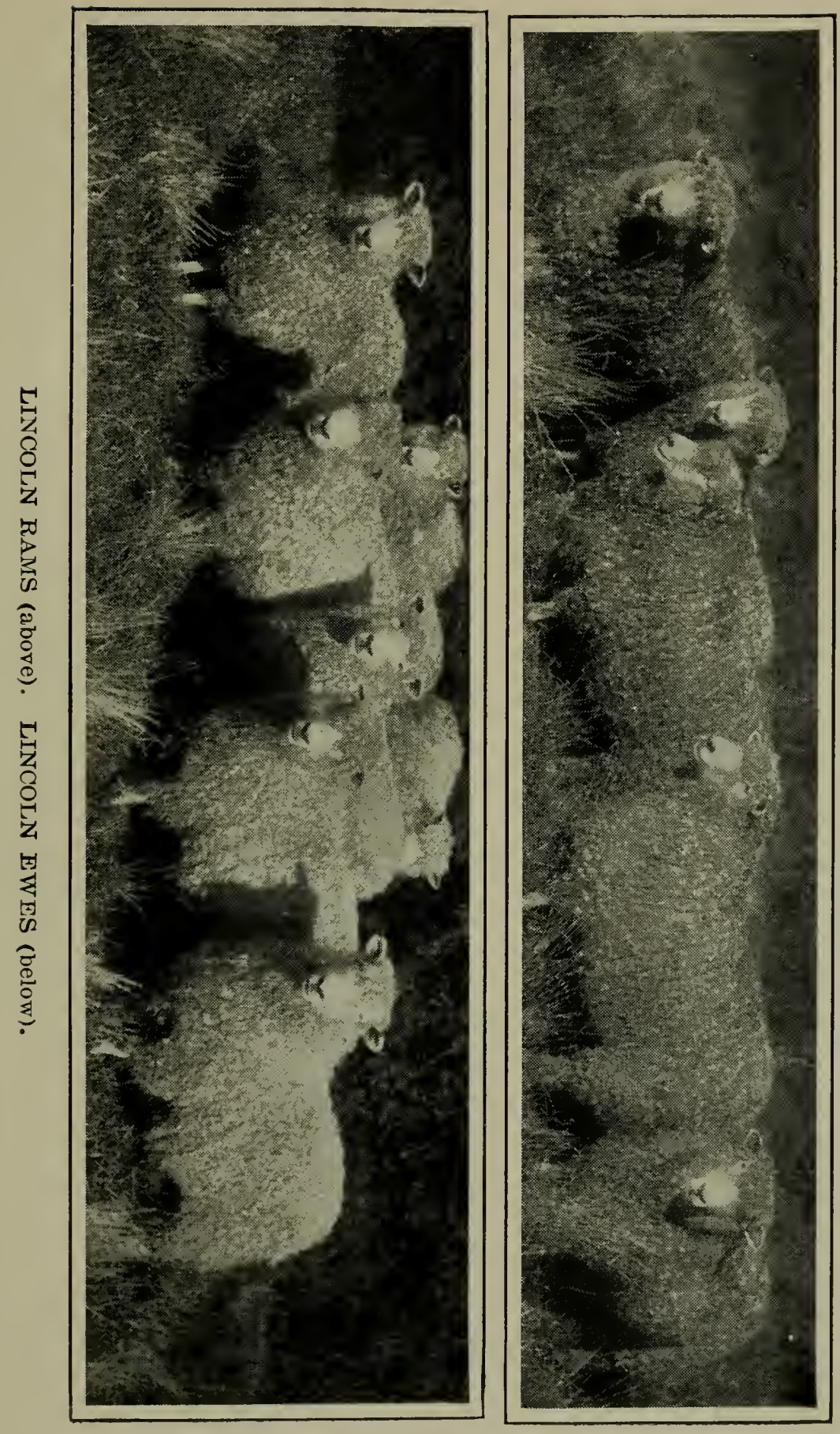



for taking on fat. In truth, it is a defect in the Leicester, according to modern idea, that it loads up too much with internal fat. Its best place in our economy is in cross breeding. Leicester rams on Merino ewes produce superb feeders with a very good class of wool.

\section{COTSWOLDS.}

One of the most common breeds in parts of America thirty years ago was the Cotswold. Common they still are in parts of the country. They abound in Canada and in some parts of the West, notably in Utah and Oregon. The Cotswold resembles the Leicester somewhat, being a large sheep with white face and legs and long wool. The face may be grayish or even light brown, and there is a tuft of wool on the forehead. The wool is coarse but adapted to certain uses. Cotswolds make gain profitably but are not adapted to the production of very young fat lambs. The best use of the breed is in cross breeding on ewes of Merino foundation, and for this purpose it has been extensively used in Montana and other Western states. Cotswolds do not thrive when kept in large flocks in the Eastern states, though they are healthy in Canada, Oregon and other cooler regions. There is hardly any more grand and stately sheep than the well bred and well fitted Cotswold as it appears at our great shows.

\section{LINCOLNS.}

Quite like the Cotswold is the Lincoln. To the careful observer, however, there is a consid- 
erable difference in the type. The Lincoln is the heaviest breed, probably, in the world, and in England Lincolns have been known to dress 90 lbs. per quarter. The wool is extraordinarily long, samples being shown of 21 inches growth, and rams sometimes shear the extraordinary amount of $30 \mathrm{lbs}$.

The new Lincoln sheep is the product of Leicester crosses upon the old Lincoln. He is truly a magnificent creation of the long-wooled character, requiring rich pastures and plenty of space. As a mutton sheep he is inferior to the Down breeds as far as quality is concerned, but for crossing purposes no class of sheep is in greater demand, and the highest prices in recent years have been paid by Argentine buyers for Lincoln rams. In truth, the great mutton exporting business of Argentina is based largely upon the use of Lincoln blood on Merino foundation, and it is not generally known that their sheep are far superior to our own in quality and are therefore much more acceptable in the British markets.

There is little doubt that when we have learned our trade better we will in turn use thousands of rams of both the Lincoln and Cotswold breeds upon our range-bred ewes to produce mutton both for our own and the foreign markets.

DORSET HORNS.

Properly, the Dorset belongs with the Downs and indeed the ancestors of the present Dorset Horns were much like the Wiltshire ancestors of 
the Hampshire Down sheep. There is now little resemblance between the Dorset and the Hampshire breeds, though singularly enough each has taken up the same field of endeavor, the production of early lambs. The Hampshire lambs usually come at a later time than the Dorsets and do not go to market quite so young, but each has the habit of fattening at an early

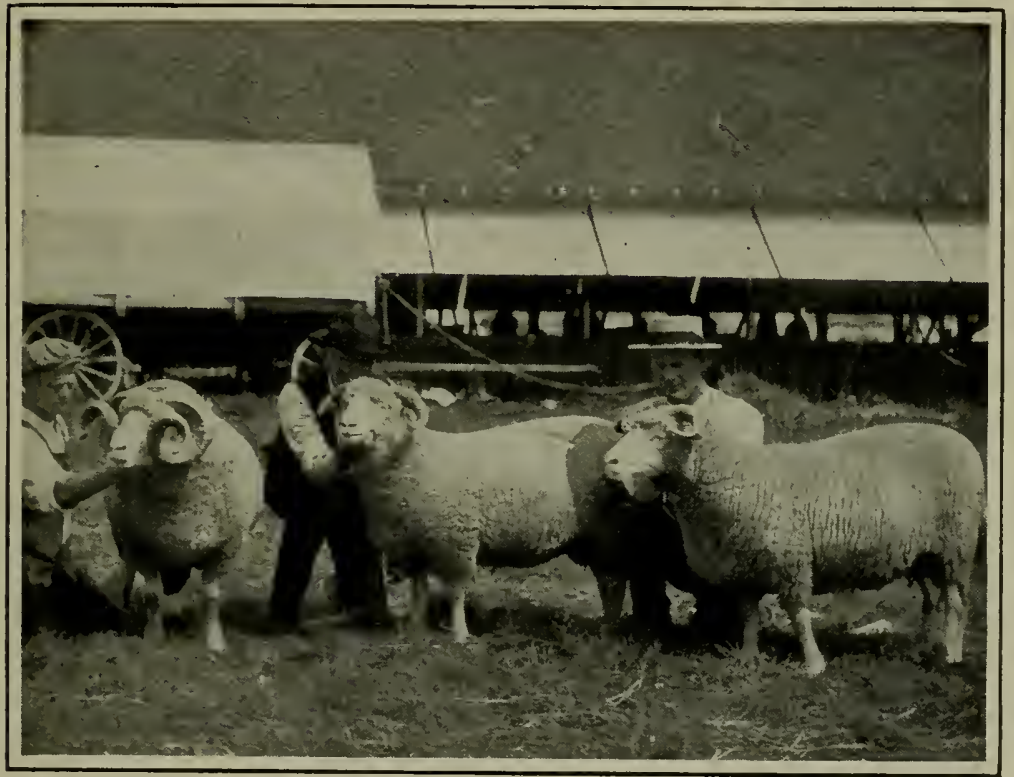

SOME OHIO DORSETS.

age, and the Dorset ewe has also the way of dropping her lambs at an earlier season than any other ewe. Then she is the greatest milker of any of the sheep tribe, and because of this large supply of milk, and because of their vigorous digestion and ability to use grain at an early age the Dorset lambs soon attain to good weights 
and are usually sold fat from their mothers' sides. In truth, it is not good practice to allow Dorset lambs to attain to an age of above six to eight months, and most profit comes from selling them at two to four months.

The Dorset, like the Southdown, is of unmixed ancestry, and is one of the most ancient breeds in existence, though doubtless much changed by selection of modern and progressive breeders. Before cows were used in the dairy in Dorsetshire sheep were kept for their milk which, no doubt, accounts in part for the wonderful milking powers of the Dorset ewe. In truth, many of these ewes are such large milkers that it is necessary to relieve them by hand stripping for a few days after the lambs are born until they become able to take all the milk.

Dorset Horns are so named because both sexes have horns. The rams' horns are large and heavy and curved rather closely in front of the head; the ewes have light horns that should curve toward the front. It is a curious fact that Dorset ewes are as pugnacious as their armament would indicate, often attacking stray dogs and lacking almost altogether that timidity that characterizes other sheep. A sheep-killing dog will sometimes kill Dorset ewes, but it is not probable that any dog would begin a career of sheep-killing in a Dorset flock.

The Dorsets have a form not unlike the Southdown, though generally more upstanding, and a similar fleece of close, strong wool, with an elastic fiber which is very white. They shear better than some mutton breeds and the wool is 
of the first quality. They are very docile and thrive in hurdles or on grass where proper care is taken to keep them from parasites. They have been introduced into several states of our country and have thriven wherever men have understood their requirements, and have failed whererer in the hands of careless or ignorant shepherds. It is notable that there are now produced in America under the conditions of the Eastern states as good Dorsets as there are in the world, whereas most of the other mutton breeds rely upon importations to maintain their quality. Dorsets find their best use in America in the hill regions of the South, where early lambs are grown. They are favorites in Virginia, West Virginia, and so far as tried in Kentucky, and in the Northern states they are largely used in the "hot house" lamb business. Dorsets are excellent for cross breeding, the lambs growing well and fattening readily, and cross-bred ewes from Merino mothers and Dorset sires form the best foundation for a flock for producing winter lambs.

\section{THE MOUNTAIN BREEDS.}

CHEVIOTS.

The Cheviot is classed as a mountain breed, of which there are a number in England and Scotland, natives of the hill regions. The Cheviot is from the Cheviot hills in southern Scotland and northern England. It is a remarkably hardy, vigorous sheep, standing erect and alert, on strong legs, carrying excellent mutton, and a 
fine fleece of good wool, rather fine for a mountain breed. There is scarcely anywhere a prettier sheep than the Cheviot. It has such an air of interest and intelligence and seems so wideamake. The Cheviots have displaced the hardier Black-faced breed in all the lower and richer parts of Scotland, though in the colder and more heathery portions this ancient breed still holds its own.

The Cheviot has a place in our land. It is well adapted to grass farms, to hill regions and wherever sheep are required to make good mutton largely from pasture.

Naturally the higher and cooler regions are best adapted to this sheep. The breed is quite well represented in America and has thriven in many parts of the country. It is in its favor that it is not too large, seeing that fat lambs, not too heavy, are now most in demand.

\section{BI.ACK-FACES.}

The writer feels that it would cause disappointment among his readers if he did not make some mention of this wonderful little Scotch Black-faced highland sheep. In their own land nothing can take their place. They have the instincts of true wild animals. They love the high peaks and heathery slopes, and, scenting storms, are led by that same instinct to seek the shelter of the glens. These sheep belong with the lands. They pass with the farm from one tenant to the other, when farms change hands. Their love of home is so great that when removed miles away they will often return straight across coun- 
try to their old haunts, swimming river's if need be to accomplish their desire.

The Black-faced sheep are small, moderately well formed, with coarse, long wool. They make good mutton, which commands in British markets a good price being thought to have a gamey character. They are a comparatively new breed in Scotland, if we accept tradition, having existed there but about 140 years. From whence they came is a mystery. There are no sheep elsewhere in the world like them, the Lonks and Berdwicks of northern England having most resemblance. They seem to be a spontaneous product, creation of enviromment, to graze those heathery hills.

Of course they had to start from somewhere, and the legend that they swam ashore from some sinking ship of the Spanish Armada is harmless and as good as any. The management of these hardy Black-faced sheep is simple; every day the shepherd seeks to see each ewe of the flock, climbing high ovr heather-clad hills with his dog at his side to accomplish this. It is his part to be sure that none of the ewes have accidentally gotten upon their backs. They are shorn in .June or July, being brought down to the farmstead for that purpose. It takes a good dog and an agile shepherd to round them up and bring them down, and it is customary to tie their feet when they are shorn, since they struggle like wild things.

In winter they are brought down to the fields and given a bite of hay and sometimes turnips. It is found, however, that too many turnips en- 
courage a growth of horn in the unborn lamb that sometimes destroys both the unfortunate lamb and its mother.

Thus it is seen that this most beautiful and picturesque sheep is one that presents unusual difficulties to the would-be breeder in America. He must beware of overfeeding in winter; he will find them hard to drive and pen; he will find them somewhat harder than other sheep to restrain within boundaries. And still there are situations, like the mountains in northern Ontario, in the higher regions of California, Oregon and Washington, and along the coast islands of Alaska where undoubtedly the natural character of the Black-faced sheep would make it of great value.

The writer has devoted this space to the breed because of its connection with legend, song and story, which have given it a place in almost every man's heart, and because he hopes to count loyal Scots among his readers. He will never forget his dars spent among the Lammermoor hills of southern Scotland, where the Border Leicesters occupied the lower slopes and the Black-faced climbed the heathery heights and their lambs played about the feet of the Twinlaw Cairns. It was a land of peace and quiet, of faithfulness and almost religious devotion to duty. The old steward of the farm had lived there in that capacity for 50 years. His son and grandson worked on the farm. High upon the slope just below the plantation of fir wood, stood a low stone cottage beaten with rain and wind, where lived the faithful old shepherd and 


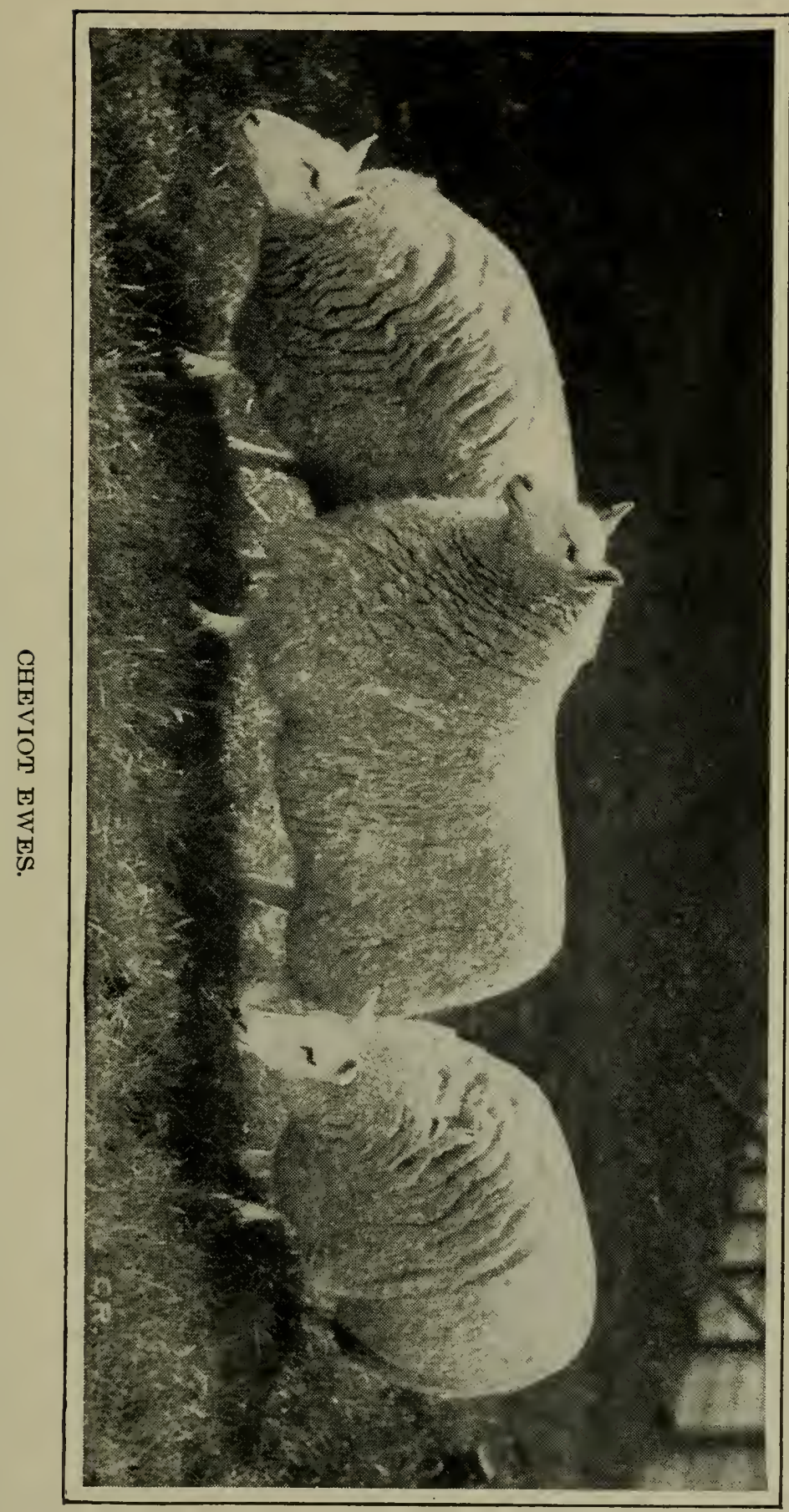



his son, and just above his cottage began a great mountain pasture, enclosed by stone walls, where there were bits of moor's from which peat was dug, and great slopes of heather, which is a small, fine and dense-growing bush on which sheep can subsist. Would that we could implant upon our own soil some such spirit as pervaded this place, the quiet and peace, the simple living and high, manly thinking, the honesty and devotion to duty!

THE TUNIS AND PERSIAN SHEEP.

In Asia and Africa began the first civilizations, and there perhaps began the first domestication of the sheep. It is a curious fact that we do not now know whence came the ancestors of our various breeds of sheep, nor do we know certainly whether they all have a common ancestry, though we may infer that it is so from the fact of their readily interbreeding with each other. All of the wild breeds of sheep at present have short tails, whereas most domesticated sheep have long tails. It is probable that the wild race from which sprung our flocks of today is extinct.

However, it is interesting to note what advance has been made by the Asiatic and African breeders of sheep and goats. The Nubian goat is probably the most developed in milking power and fecundity of all breeds of goats and the Persian and African sheep have also strong development in certain ways fitting them to the climates and environments in which they were produced and to the needs of their owners. 
The Persian and Tunis sheep have evidently common origins and belong to the same race. In truth it would seem to the writer that the $\mathrm{Tu}$ nis breed which has existed in America since about 1799 and which now may need some infusion of fresh blood might with advantage receive an infusion of Persian blood.

The Tunis came to America early in the last century, and was bred near Philadelphia, and afterwards in South Carolina and Georgia where they proved to be well adapted to the environment. The civil war almost destroyed them. A few survived and were shown at the Columbian Exposition in Chicago. Soon thereafter some enthusiastic admirer's began breeding these sheep in Indiana. It is possible that in their time of adversity the blood of the Tunis was not kept quite unmixed, since there is more variety in type among them than is usual among pure breeds.

The distinguishing character of the Tunis breed is the head, which should be hornless, covered with tawny yellowish brown hair the nose may incline to roman character, the ear should droop and be rather heavy. The form is much like other mutton sheep except that the legs are usually long and the neck the same. The fleece is soft, fine, fairly abundant, and varies much in color; it may be white, or brown, or reddish, or the colors may be intermixed. In the Persian the same characteristics are noted, with a likelihood of black predominating.

The distinguishing feature of the Tunis is the fat tail. This seems to have been originally 


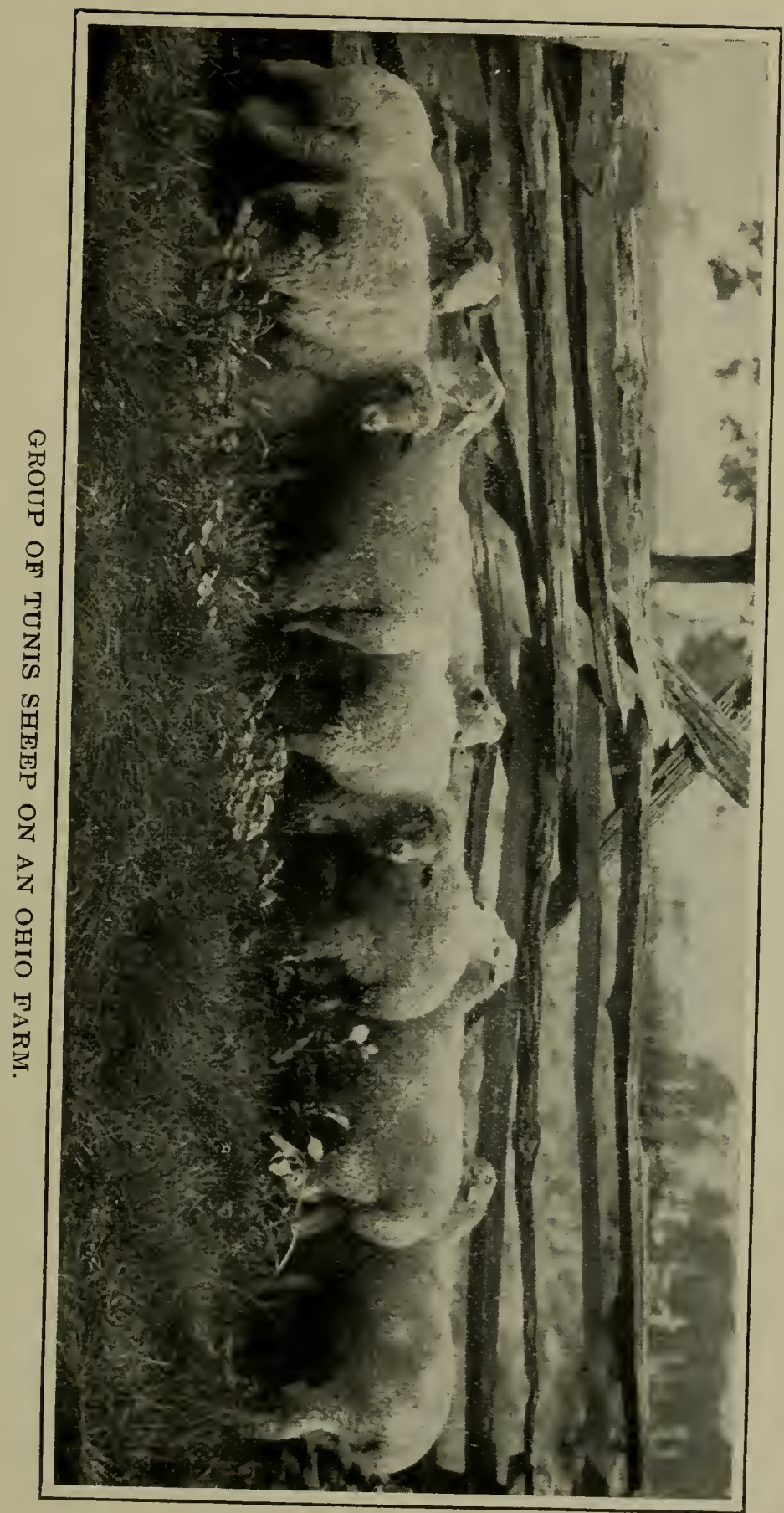



planned as a store-house to tide the animal over periods of drought and bad pasturage. When tails are not docked they are moderately long and the fleshy part hangs down about six or eight inches. This is so inconvenient at the breeding season that ewes usually have their tails docked, besides there is in the United States no popular clamor for fat tails, which are in African and Asiatic regions considered very delicious and are used in place of butter.

When the tails are docked there is yet an accumulation of fat across the top of the rump.

'Tunis sheep fatten very readily and their lambs are especially quick to become plump and ready for the fancy hot-house lamb trade. It is for this purpose that they are mostly used, though the Tunis rams crossed upon almost any breed of ewes get good lambs.

The Persian sheep were introduced into the United States in 1891 and bred in California, Nevada and other Western States. They are very large, very active, good feeders on the range, and when crossed on Merinos the lambs prove to be very easily fattened. Of a herd of half-blood Persian-Merino ewes a California owner says: "They are omnivorous feeders and great rustlers for food. If there is anything between heaven and earth to eat they will get it." The writer has observed a tendency among some Persians to foot disease when kept on wet soils. They are true sheep of the desert, and there they would seem to have a useful place.

Among the breeds described the would-be sheep owner can choose one and he should stick 
to that one. Cross-breeding is permissible for the market, but let no one undertake at this day to create a new breed of sheep by mingling the bloods of breeds already having received the care and thought of generations of skillful breeders. One man's lifetime is too short to establish a breed, and there seems small need of another. 


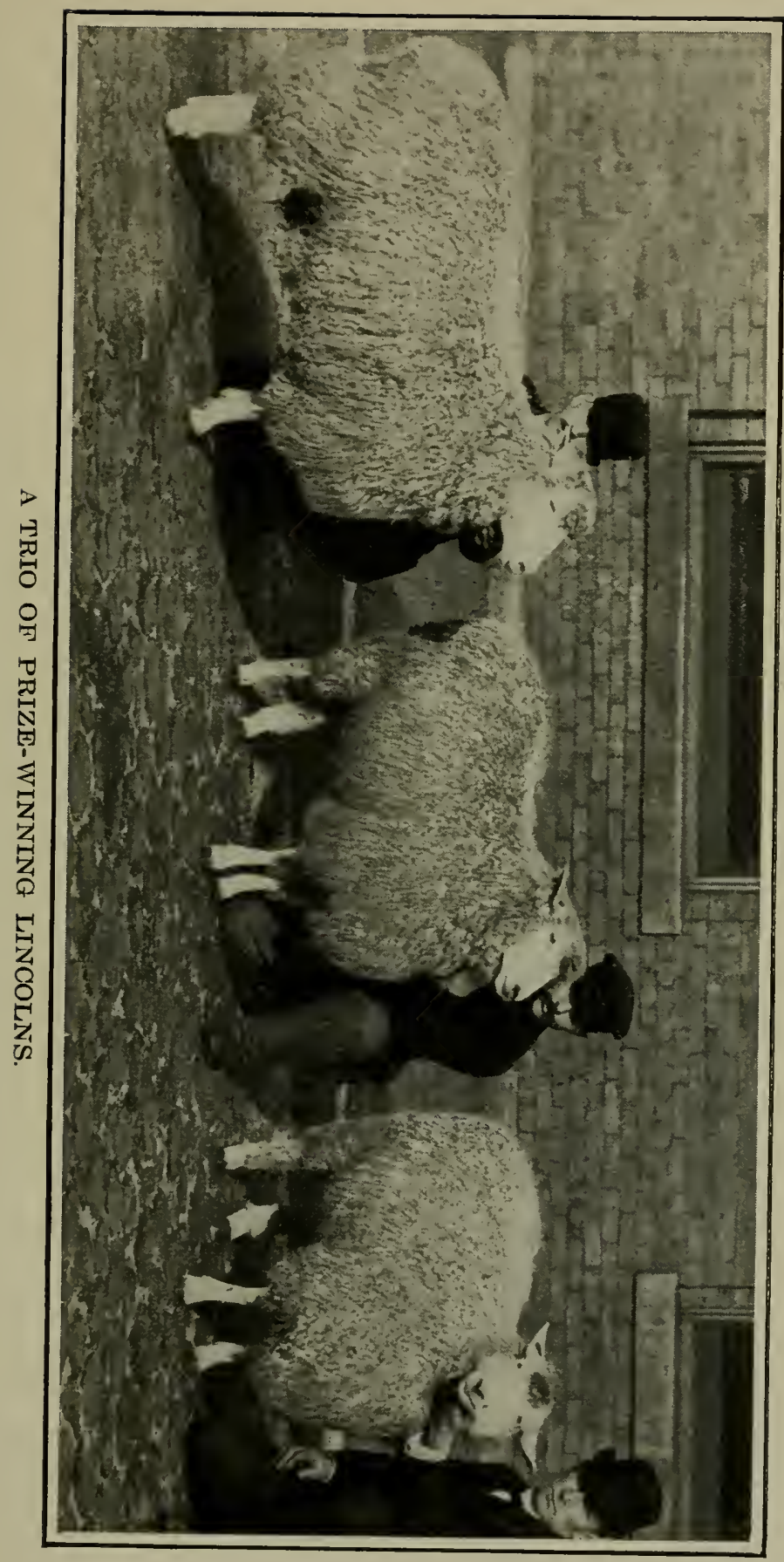





\section{CHAPTER III.}

\section{CROSS-BREEDING.}

Notwithstanding the great excellence of many of the pure breeds of sheep it will be a long time before we will be free from the practice of cross breeding. There is a necessity for this in sheep breeding much more urgent than in cattle breeding, or in fact, with any other farm animals. Very few pure bred sheep reach our markets. Nor will they come in large numbers for many years. The reason for this is to be found in the fact that so large a per cent of our sheep are grown upon the western ranges. There ewe flocks seem most profitable when they have a Merino foundation. Merinos from time immemorial have been range sheep, the only break in their habit being the few decades that they were kept upon eastern farms. Merinos are hardy, are used to droughts and short feed, have the instinct of herding, are easily managed. Moreover they retain their wool well up to considerable age. Wool is a far greater factor in Western sheep husbandry than it is in the country to the east. Flocks must be good shearers, must be hardy, must herd well.

But the Merino when kept pure is an inferior mutton sheep. Moreover it is an inferior breeding sheep. An infusion of mutton blood makes the ewe a better mother, her lambs are stronger, 
she suckles them better. She feeds better, too, and is a "better rustler." Then her progeny is in large part destined to reach the great markets when about six months of age. Therefore the better grown and heavier it is the more money it will bring. Thus there is often sought a class of rams that will make the best lambs, regard-

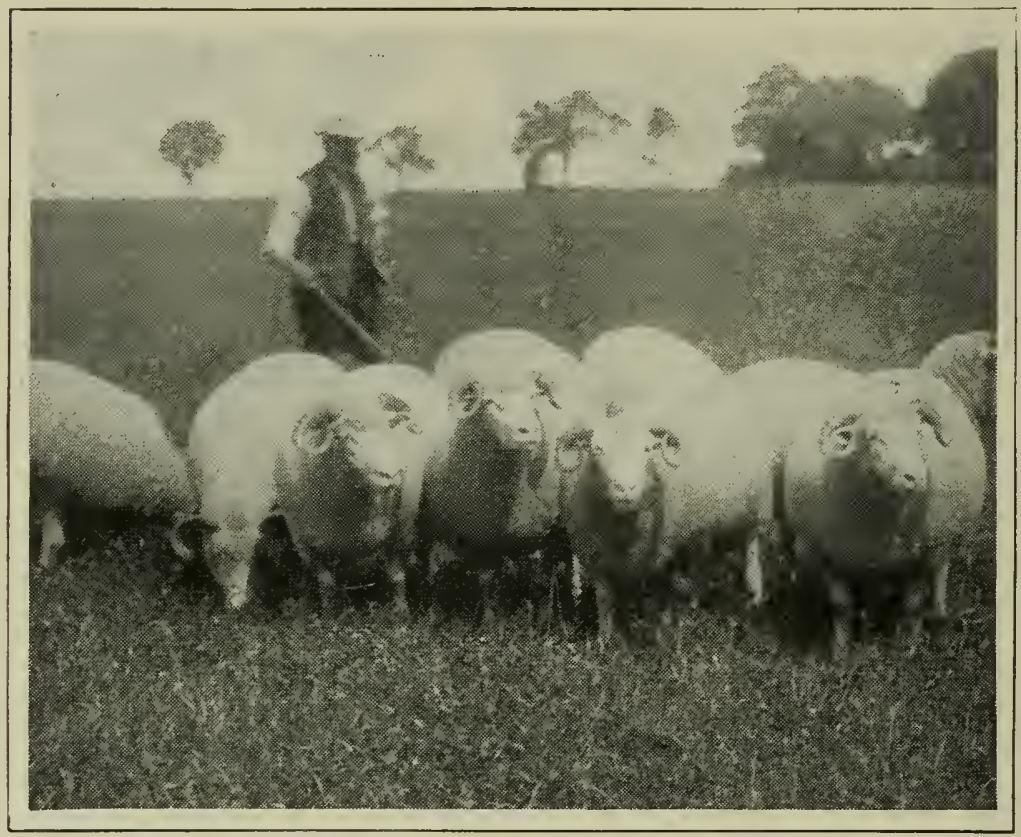

DORSET EWES.

less of their fitness for long continued life upon the range, they will not naturally remain there more than one summer. Thus the complexity of cross-breeding is increased for from the mother having in her own body an infusion of mutton blood there is secured a lamb having a sire of 
pure mutton breeding. What sort of cross makes the best ewe, what sort of cross upon her makes the best market lamb? To this question there would naturally be as many answers as there are supporter's of breeds of sheep. There is hardly any commingling of bloods that has not use for some special environment. We may clear the matter up somewhat by discussing a ferr crosses and their results.

At the outset let it be said that the influence of the sire and dam are theoretically equal. Some hidden power of the one or the other may seem to cause the offspring to resemble more nearly the one parent than the other, but no man can safely predict whether this influence will reside in the sire or the dam. Naturally, as she nourishes the lamb, the ewe has greater chance to influence her progeny than the sire. Thus if a ewe of a small race is mated with a ram of a large race the lamb must be nourished, both before and after birth, by the smaller ewe. It will grow to be of greater size than its mother, but will not equal the size of its sire. Nor will it be identically the same as though the cross was reversed. That is, supposing we are considering the Merino of one of the lesser strains, and the Hampshire, the natural way of crossing is to use the Hampshire ram on the Merino ewe. The result is a lamb that grows to be larger than its mother, and smaller than its sire.

Reversing the process, we choose a typical Merino ram and mate him to a Hampshire ewe and get a lamb that never equals its mother in stature, but excels considerably its sire, and also 
excels the lamb of identically the same blood from the Merino mother. The better nourishment both before and after birth causes this result. It is seen then that the better the ewe the better her lamb. Nevertheless, it may happen that a class of moderately small ewes may yield most profit since they consume forage about in proportion to their size, thus a flock of 1,000 medium sized ewes bred to fine, strong mutton-bred rams would very likely yield a better weight of lambs than a flock of 800 larger ewes and consume practically the same amount of teed.

In other words, the ram is just half of the flock, and by far the easier half to provide the forage for. Thus the ram cannot well be too good.

To freshen the blood of the pure Merino on the range a number of infusions have been tried. The Cotswold blood does well; a flock having one-quarter or even one-eighth of Cotswold blood is increased in size and stamina remarkably. To get a flock of one-quarter Cotswold blood one must first get one-half blood CotswoldMerino rams to use on his pure-bred Merinos. For some exceedingly rich ranges the one-half blood Cotswold-Merino ewes are used and with good success. These ewes are exceedingly good forager's and raise hardy fast growing lambs.

The Lincoln cross does admirably on some types of Merino ewes and is much esteemed in some regions of the West. The Oxford cross has given good results also as a permanent infusion in the range flock. There are a few sheep 
owners who use the Hampshire for this purpose, though the general opinion is now that the blood of the Downs cuts short the yield of wool.

The Leicester blood makes an admirable infusion into the range flock. It is said that not more than one-quarter or one-eighth of it is needed to give strength and hardiness. The Dorset has been tried and found worthy; some of the best range ewes the writer has ever seen have been in part of Dorset blood. Dorset blood especially helps the milking qualities of Merino ewes and makes them able to push their lambs forward astonishingly.

Though the writer knows of no instance of its use he is of the opinion that the use of Cheviot blood would prove a very desirable addition to herds ranging in the mountains of the Test. Probably one-quarter of Cheviot blood would be enough. Cheviots make flesh readily from grass alone and are remarkably hardy and are very great rustlers for feed.

CROSS-BREEDING FOR THE LAMB MARKET.

Considering the restern range sheep first. various breeds have been used for production of market lambs. At one time the Long-wools, Cotswold, Leicester or Lincoln, were considered best for this purpose. Rams of either of these breeds will beget fine, strong lambs that will feed well and grow to large size. They will not he sn fat at weaning time nor come into market so early as lambs from one of the Down breeds, but they do splendidly in the feed-lot and attain heary weights. 
The Hampshire gets splendid lambs, well marked with brown points, easily made fat and selling near the top of the market. One can hardly make a mistake in using Hampshire rams if he wishes to make market lambs. Hampshire grade lambs will usually be fat enough for the butchers when they come from the range, and if they are fed will ripen very early. They attain to large weights.

The Oxford ram gets a lamb a little larger, probably, than the Hampshire, a strong, hardy fellow, that feeds well. He weighs heavy and makes good, but not so early as the other Downs.

The Shropshire ram gets fine, active, growthy lambs that mature sooner than the Oxfords and sell first rate. They will usually be fat enough for the killers when they leave the range.

The Southdown gets merry, plump, roly-poly lambs that are fat first of all and are apt to bring most money per pound in the market. They will not weigh quite so much as the Shropshire grades, but will be ripe earlier. The Grand Champion load of range lambs at the International at Chicago in 1906 was a load of Southdown cross-bred lambs. The western flock-master need not fear to use Southdown rams if he means to sell the lambs. They will make good and that very early.

The Dorset gets lambs that weigh unusually well and the ewe lambs should always be saved to be put in the flock, since Dorset blood in the ewe flock is a gold mine to the flock owner. 
Cross-breeding on the ranges is not without its difficulties. The problem is to maintain the original ewe flock in its integrity. Cross-bred lambs that may sell for the top of the market at the river markets may be unfit for retention on the range, because of the too large proportion of mutton blood. The best plan is to breed a portion of the ewes of highest quality from the standpoint of the range man to rams especially suited to range use, and thus to maintain the flock in its required qualities, letting all of the cross bred lambs go to market.

\section{CROSS-BREEDING IN EASTERN PASTURES.}

There is not the same reason for cross breeding in eastern lands. In truth too much of that is done at all times and types are destroyed by useless combinings of bloods. If one starts out with a Shropshire flock he should endeavor to make it a better Shropshire flock by purchase of better Shropshire rams than he has been in habit of using. If he needs greater vigor and constitution he can get it probably quite as easily by choosing an unrelated ram bred, it may be, at a distance from him, having first rate vigor and constitution, and of the same breed. The same is true of the Cotswold, Oxford, Southdown, and other breeds. There are not enough of the pure breeds now, and they should not be mixed unless for some special purpose, and it must be remembered that as the cross-bred progeny should go to market the process of cross-breeding is a suicidal one. 
There are occasions, however, when crossbreeding on the farm is desirable. One may buy Western ewes and ship them home. These are destined for lamb growing exclusively and no attempt will be made to maintain the flock. These ewes then may be mated with a ram suitable to the market and the time of year aimed at. If for hot-house lamb trade a Southdown, Tunis, Hampshire, Shropshire or Dorset should be used. If to lamb later and grow the lambs mainly on grass the Tunis and Dorset may be eliminated and the Cheviot and Oxford added to the list from which rams may be drawn. Or if the lambs are to come late and be fed the next Winter one of the long-wools may be chosen. $\mathrm{Or}^{\mathrm{r}}$, if the flock happens to be placed in one of those rare regions like the hills of Ohio where sheep are yet grown largely for their fleece, the Delaine or Rambouillet, or Spanish Merino ram may be used.

There are regions, however, where cross breeding is imperatively demanded. That is in the early lamb breeding regions of the Virginias, Tennessee and Kentucky. Here are found types of native mountain sheep of a peculiar character. They may be said to be true "American' sheep, descendants of the earlier importations. The unmixed native mountain sheep is leggy, thin in neck, light in fleece, having somewhat of an open fleece as though coming from an open-wooled breed, and very often the ewes have horns. It may be supposed that the first colonists sailing as they often did from Bristol and Plymouth, in the south of England, brought with 
them the native sheep of those regions among which would be the Dorsets and various types of long-wools. These mountain ewes though not handsome to look at are better than they at first appear. They are active, good feeders, very prolific, and good mothers. Their lambs are not of first rate quality unmixed, but when sired by rams of good mutton type they grow finely and sell well. The favorite sire for this business has been the Southdown, in truth no breed can get a better lamb or one ripening earlier than this old standby. Shropshires are often used, also, and get a heavier lamb. Hampshires are in great favor where tried and Dorsets have their strenuous advocates, especially in Virginia, where they have been used most.

The advantage of Dorset blood is two-fold, first the lambs attain very good weights, usually outweighing the progeny of Down rams, and the ewe lambs if retained on the farm, make admirable mothers for successive generations. Lambs in these regions are usually born in March and fattened mainly on grass, going to market in June and July. The source of supply of these ewes is from the small farmers in the mountains. Could these men be induced to improve their flocks by use of better rams the benefit would be immediate and marked. There is no doubt that an infusion of fresh blood from any of the Down or Dorset breeds would greatly benefit these mountain flocks. At present they are suffering from the result of long continued inbreeding. An infusion of fresh and unrelated blood would marvelously improve them. 


\section{CHAPTER IV.}

\section{SELECTION AND MANAGEMEN'T.}

\section{RESTOCKING A FARM WITH SHEEP.}

Supposing that we have decided to embark in the sheep industry, and have decided on a breed, the next consideration is how to set about filling the void of sheep upon our farm. Farms differ in size, conformation and soil; conditions vary greatly, so that no rule can be laid down that will be applicable to all places, yet there are a few facts that are of general application. In England and France there are farms almost entirely devoted to sheep; they carry little other stock, and grow crops mainly to be fed to the flock, with only grain in rotation.

These farms are very profitable when well managed, and greatly build the soil and the fortunes of the owners. We can not yet advocate the attempt to establish in our land such sheep farms as these, at least the growth of such a farm should be very gradual, and any attempt at to once establish such a one would result disastrously in nine cases out of ten. We have no class of expert shepherds such as would be needed to care for a flock on such a farm, nor 
would the importation of British shepherds help us, for we have problems that they know not of, and our range of feeds is quite different from theirs. With a right understanding of the matter and a gradual adaptation of our farms to sheep growing, and a habit of care once formed we can devote whole farms to sheep as well as

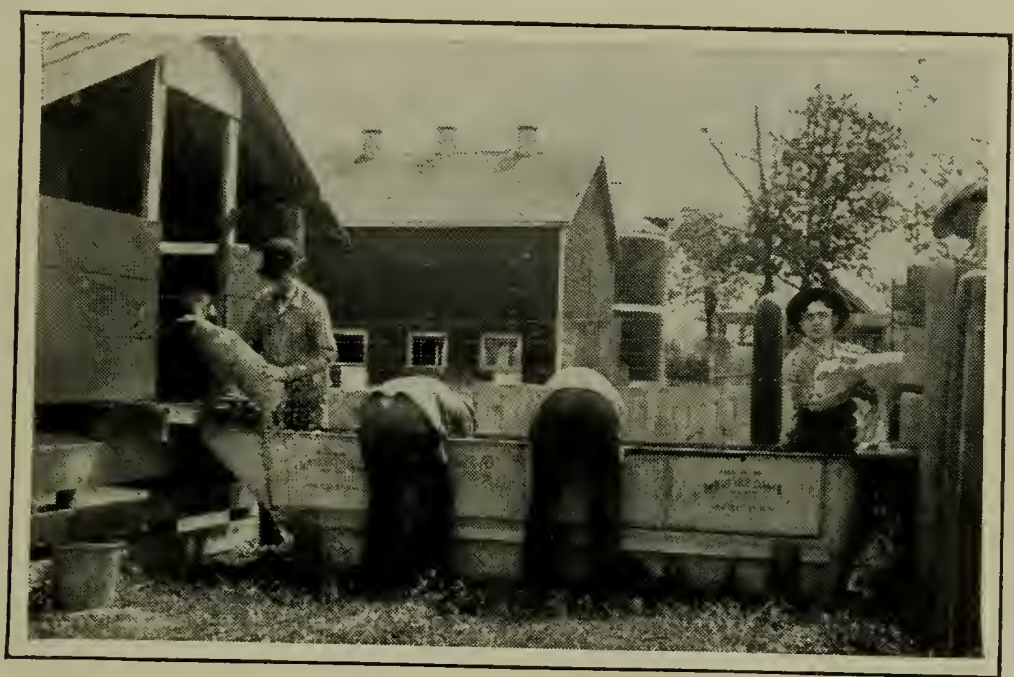

DIPPING SHEEP AT THE UNIVERSITY OF WISCONSIN.

our British cousins, but that is a work that must come with time and experience.

At present, then, the farmer should start with a small flock, letting it increase gradually, and trying to grow in knowledge and experience as the fiock grows in size.

Nor would it be wise or prudent to begin with a flock of pure-bred ewes. A few pure-breds should be purchased, say ten or twelve, the rest of the flock may well be of grades. The ram 
should always be pure-bred and of as good quality as can be secured. He is half the flock, and if he is mated with grades and is required to supply all their deficiencies he has great need to be a good one.

SELECTION OF THE RAM.

Choose not an extra large ram, but one of medium size for the breed selected. Size does not always go with vigor or prepotency, or ability to transmit good qualities. It is rare that the largest ram of a lot has the most vigor or quality. Choose a ram that has short legs (they go with early maturity), witlı wide breast, avoiding the rams where "both legs come out of the same hole in the body," choose the one with well sprung rib and a level, straight back, looking of course for a good leg of mutton, which is after all, about all that there is in a sheep, from the butcher's standpoint. Then be sure that there is a thick, muscular neck, a bright, quick eye a brisk movement denoting vim and vigor. Such a ram will leave his impress indelibly upon the flock If one can not personally select his ram, he may often leave it to the good judgment of the seller, specifying what is wanted, and the novice will generally get better service from the honorable vendor than were he to attempt to select for himself.

Fleece is of course important, and minor points, such as markings and absence of scurs or horns on all breeds save Merinos and Dorsets. But first of all in importance is it to get a ram boiling over with vim and vigor. 


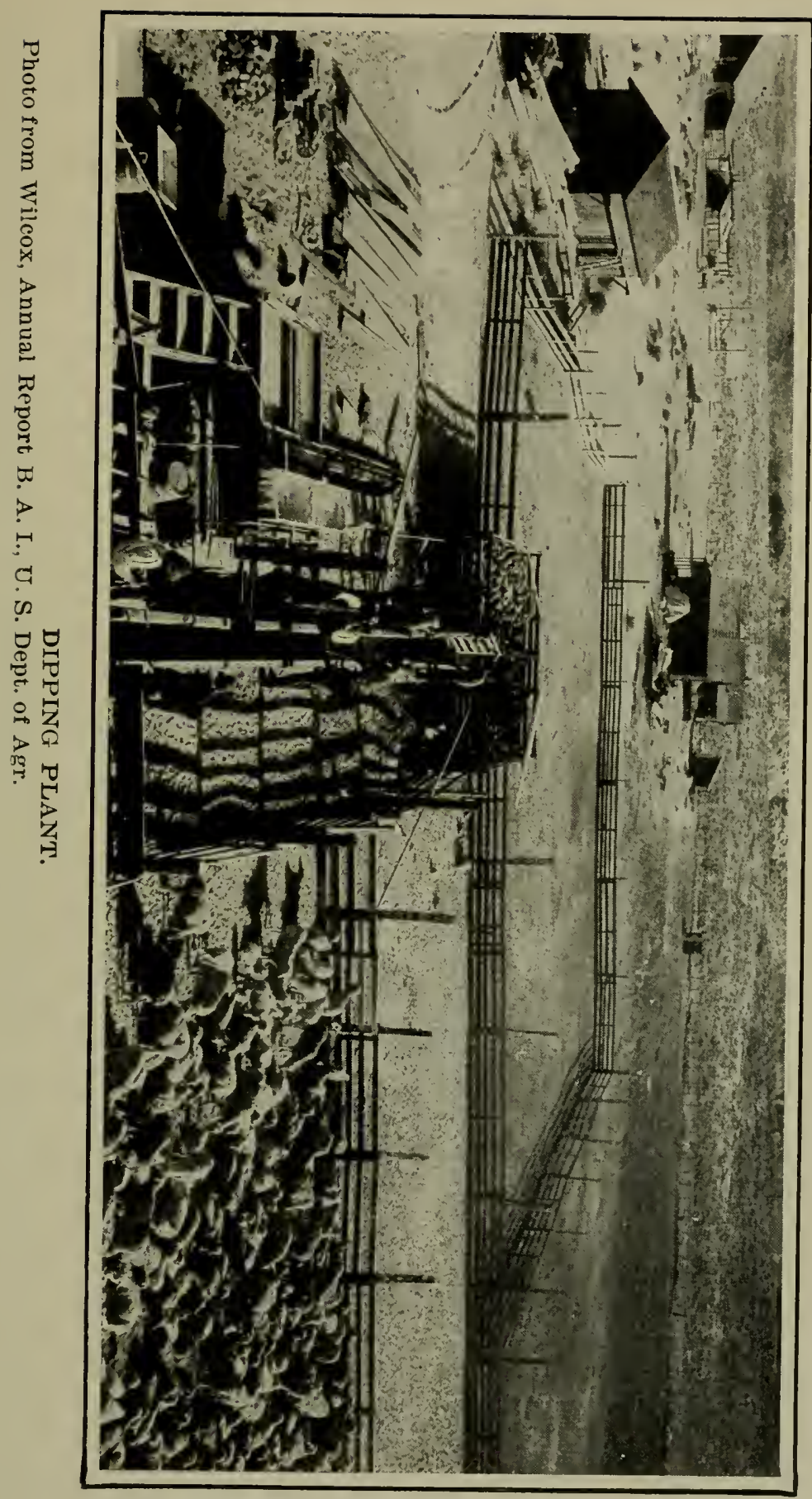



A ram of such character will readily care for $40 \mathrm{or}^{\circ} 50$ ewes if hand coupling is practiced, allowing but one service to each ewe. He may indeed go to more than that when in his prime, aged from one year to four or five.

\section{KEEPING A TYPE.}

At the show ring one often hears a remark from some student of breeds, "that is a good pen, but off on type," or, "that is a good sheep, but not of the right type for the breed." What, then, is type?

Type is style, conformation, character. It is a something distinct and definite, though hard to describe, that belongs with each breed. It may not always be of much value, from a dollarand-cents standpoint, yet a flock lacking in type is not attractive and can not hope to do much in the show ring. For example, a Cheviot true to type has an erect ear, an alert manner, a way of carrying its head. A flock of Cheviots that lacked this erect ear, this sprightliness of look and carriage, would fail very much in type and would not be attractive. Types change as ideals change. The Shropshire has undergone a notable evolution within 20 years, has decreased somewhat in scale, has gained in compactness, in covering, in beauty. The shepherd should study type so as to know what the correct ideal is for his own especial breed and then choose his ram to help him fix that type.

This does not mean that he should be a slave to other men's caprices, there are fashions that are foolish and that sooner or later will work 
the undoing of their followers. One is wise to steer clear of them as far as he is able. Or a man may have within him the creative instinct that will enable him to evolve a new and better ideal, and to breed a new and more desirable type. There is need in America of much more independence than exists now in this matter. The last thing has not been learned in sheep breeding, nor in all cases the most profitable type evolved. In England there is a constant evolution going on and breeds do not remain stationary very long. Their work is done in various ways, usually by selection and careful matings, sometimes by judicious and skillful introduction of new blood. This is more easily accomplished there than here owing to the lack of prejudice against such practice and the different rules of their flock books.

Here is an illustration. It throws much light upon the creation of breeds in the good Old World. The writer met a breeder, of, let us say, Dartmoor sheep. (In fact it was another breed.) This man was exhibiting at the Royal show, and pressed the writer to visit his pens and inspect the sheep. There was among them an especially good ram and the following conversation took place. Writer, "he is a splendid animal. I should think he would get first in his place."

"Indeed, I hope he will, and championship too, and I think he is sure of both if the judge does not think him too good."

"But how can he be too good, he is pure Dartmoor in blood is he not?" 


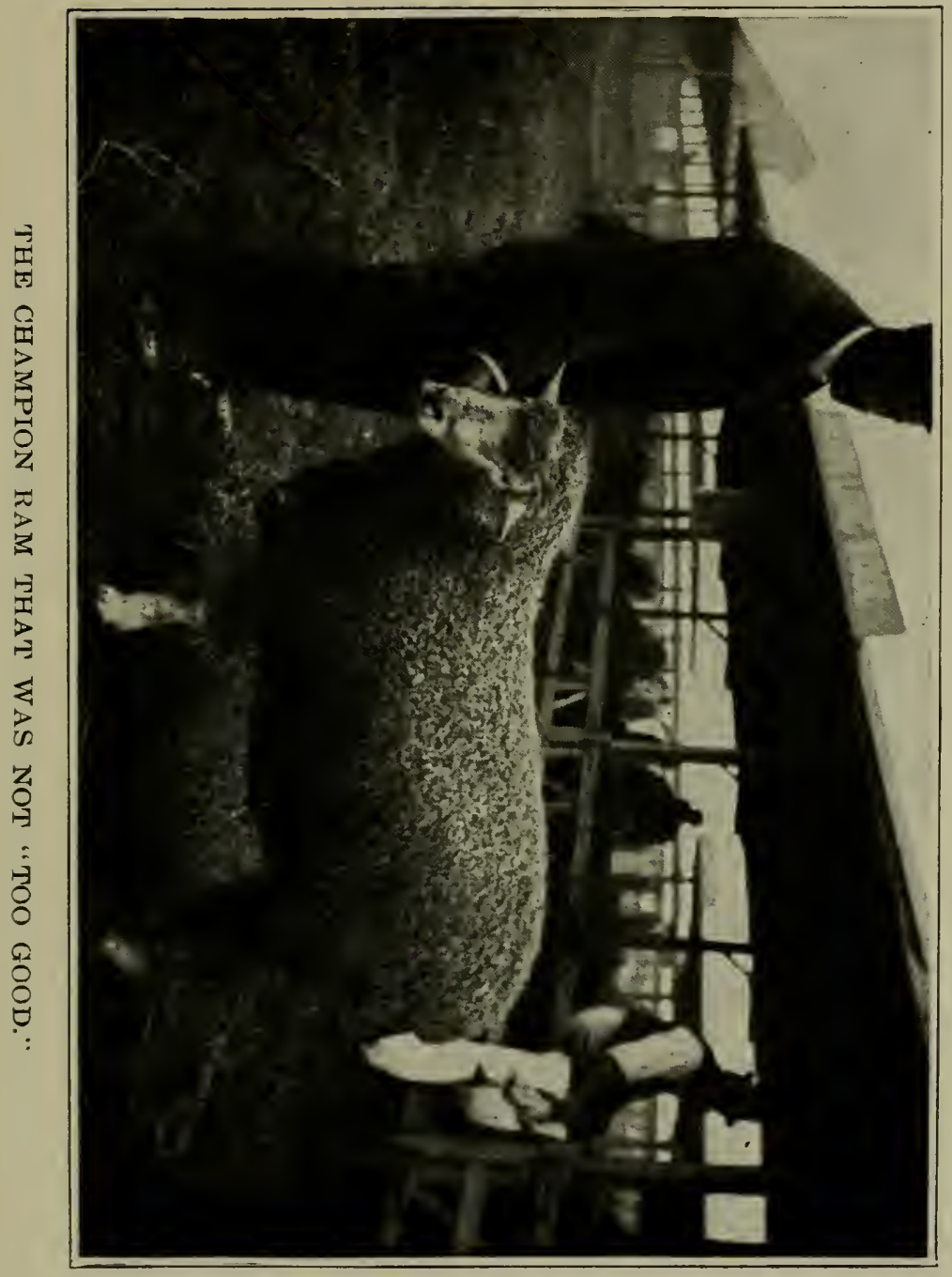



"Well," cautiously, "I'll not deny that there may be a drop of other blood in him, just a drop, and not too much." The writer saw the point, and curiosity led him back after the showing. He found the owner jubilant. "Did your ram win first?"

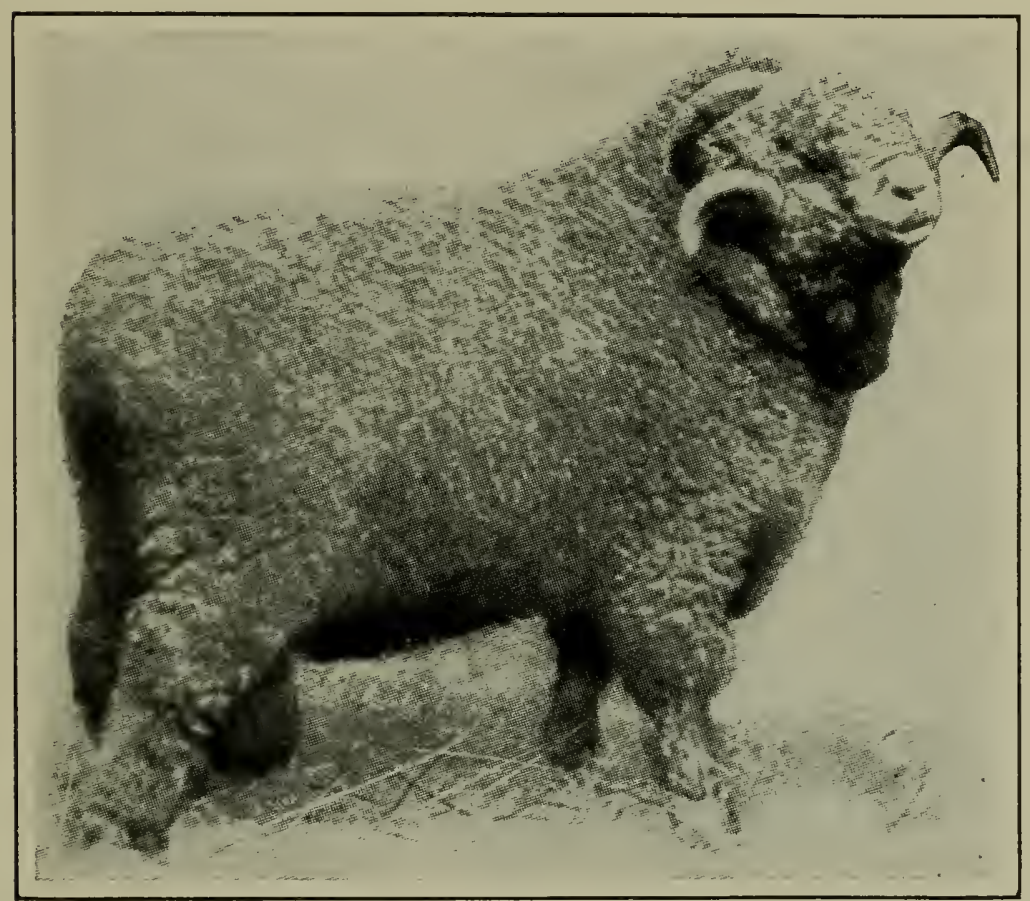

RAMBOUILLET RAM.

"Indeed he won first, and championship too." "And what did the judge say?"

"Indeed the judge said that a Dartmoor could not be too good.",

However, the writer does not by any means advise the ordinary breeder to attempt to help 
his breed by an admixture of foreign blood. That is for the great creators with unusual instinct and insight and patience and perseverance to undertake.

\section{FIXING TYPE.}

Sometimes one has in his flock a few individuals, or maybe but one, that is of unusual beauty and excellence. This may arise from a skillful combining of blood lines within the breed, or there may be born within the flock an animal different and better than any of the others. We may not be able to point the reason for this difference, this betterment. It is, perhaps, a " $\mathrm{mu}$ tation' as the newer students of breeding would say. However it came, it is such that we wish very much to fix it in the flock, to breed many like unto it. How can we accomplish this? To fix it in its entirety may indeed prove impossible, if we have but one animal possessing this unusual excellence. The best that we can do is to breed it, supposing it to be a ram, to a number of the most likely ewes and save the ewe lambs that come nearest the type sought. Should any of these ewe lambs show weakness of constitution they must be rejected, or at least ignored in this effort, and the strong ones may be bred to their own sire. The progeny of them will carry three-fourths of his blood, and will be much like him in appearance and character. Supposing, now, there happen to be two lambs each having unusual quality, possessing this desired type, each sired by the same sire but by different dams. They may be bred together and 


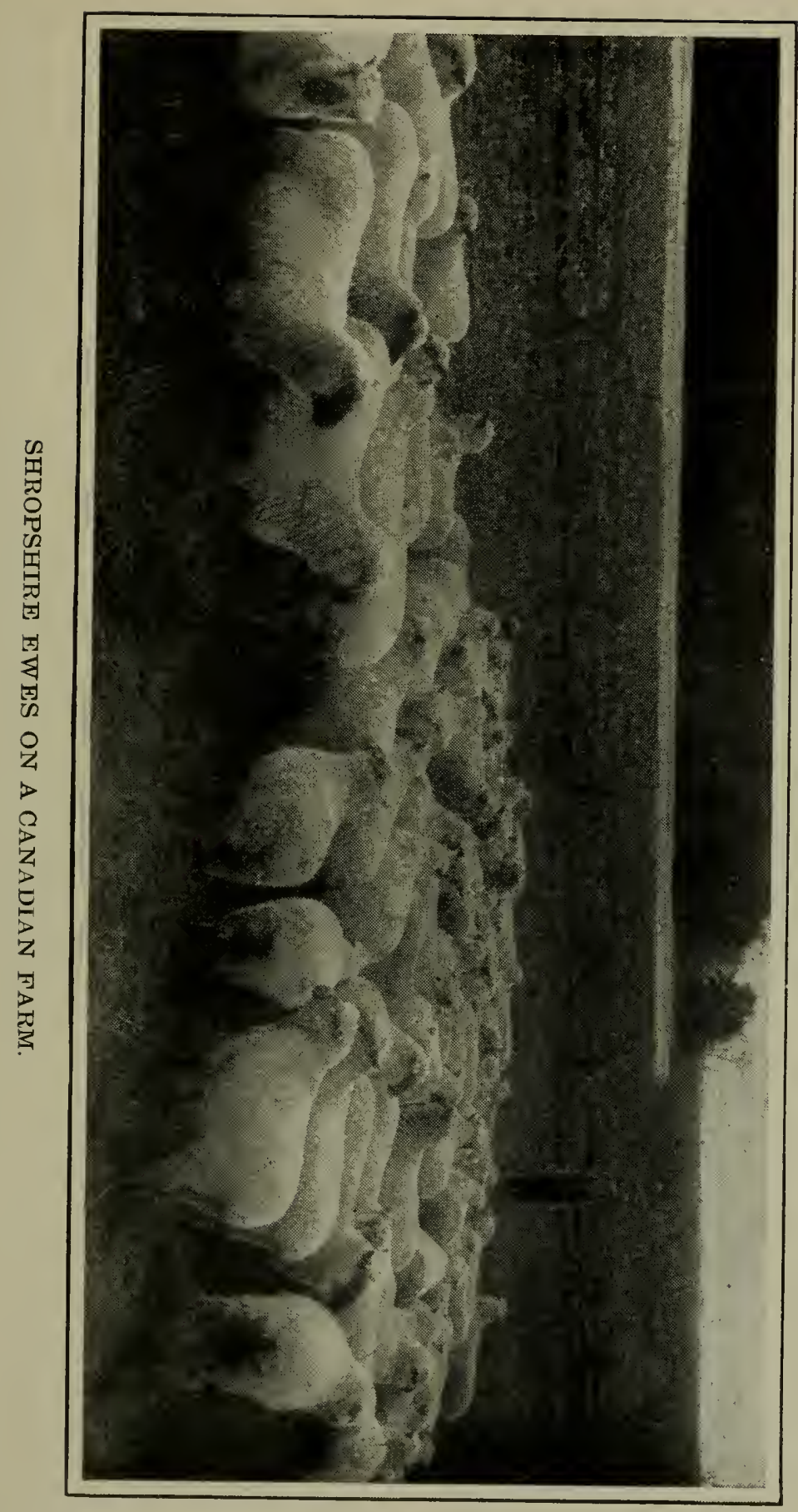



another step taken towards fixity in character.

It is worth considering that in breeding a ewe to her own sire one is not inbreeding more than when he breeds together two animals born from two ewes and having a common sire. The closest in-breeding is when a ram is bred to a ewe having the same mother as well as the same sire.

There is absolutely no other way to fix type or to get great uniformity in a flock than this system of inbreeding. It has been adopted to

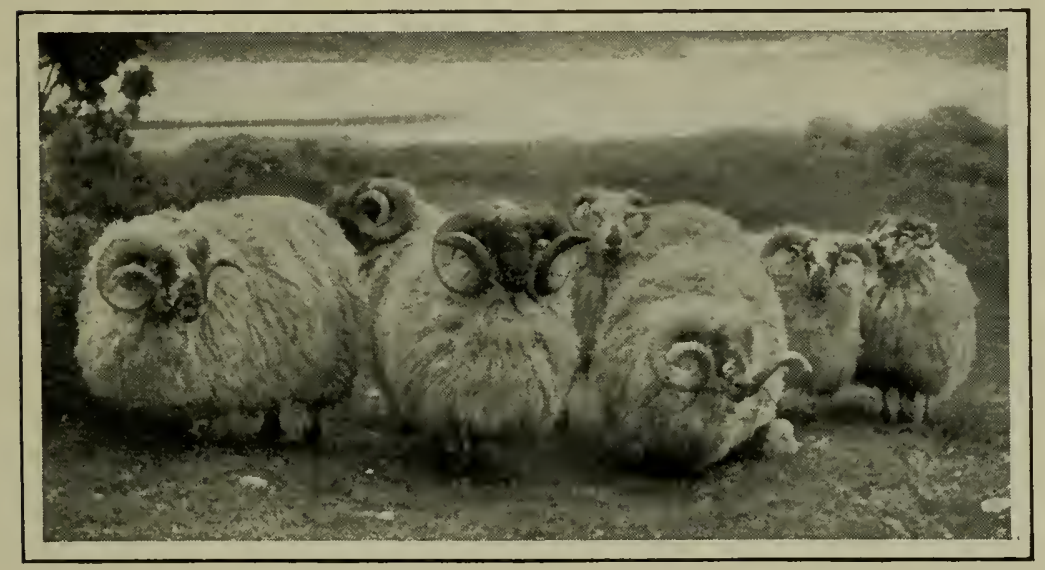

BLACK-FACED RAMS.

a greater or less extent by all the great improver's of breeds.

There are certain dangers inherent in a system of inbreeding. Nature permits a certain amount of it, but it is done always under the law of combat. The strongest male gets possession of the females, thus nature's weaklings, no matter what the form or fleece are weeded steadily out. Under Nature's system the males 
of all animals of the deer and sheep families roam far during the breeding season and it is unlikely that incestuous breeding is very common.

The effect of incestuous breeding is not well understood and there are men who deny its dangers. There seems, however, to be abundant evidence that it develops an accumulation of weaknesses of constitution, it makes the progeny delicate and lessens its size and vitality.

Furthermore, it often seems to lead to partial or total sterility. Not to go deeply into this debatable subject we will say that inbreeding is probably absolutely necessary in the creation of breeds and in the further development and fixing of types, but that it should be attempted only by the skilled breeder, the man sure that he has a type worth fixing. The man who is breeding for the market will find that he will do best to keep as far from in-breeding as possible. And this brings us to

RENEWED VITALITI FROM FRESH BLOOD.

There is something wonderfully invigorating in the mingling of unrelated bloods. This has long been recognized by the adrocates of cross breeding. It has indeed become a wellknown saying that "cross-bred animals are most thrifty." "Cross-bred lambs fatten first." Among cattle breeder's the truth is admitted, and swine breeders very often cross-breed for greater vigor and thrift.

It is not so generally known that the bringing together of unrelated animals, especially of 
the same breed if they may happen to have been grown under different environment, most usually brings as much added vigor and thrift as though two distinct breeds had been brought together. There is great advantage in bringing vigor without losing the breed and its special character and purpose.

The man, then, who finds his well-bred flock needing a renewal of life, needing a general "toning up" and rejuvenation should not resort to cross-breeding, supposing that he has already a breed of value for his purpose, but should seek within his own breed sires as remotely related as he can find, and possessing as much health and vigor as he can find.

He will find a marvelous result to come from this new mating with fresh blood. His old flock has in it latent excellencies that lie dormant only because the spark of life has burned dimly for a time. With the renewal of that vital spark and the greater intensity of life that results these old and almost forgotten excellencies will be in a manner revived, so that the progeny may be not merely better than the dams but better than the sire as well. The writer has seen very striking instances of this, when the ewe flock was of good inheritance and only suffering from lack of fresh blood.

VITALITY THE THING TO STRIVE FOR.

The sheep under domestication is not so strong as we would like to see it. In truth there is no animal under our care with less resistance than the sheep. Men do not enough consider 
this. They study points, like the quality of the fleece, or the form of the head, the covering of the legs or nose, the shape of the ear, and doubtless these are all essentials, but the first and foremost essential in a profitable flock is vigor, vitality, life. That, if it is abundant, will insure strong lambs, will insure ewes with right mother instinct and milk to serve that, will insure lambs that eat and thrive and grow and fatten and bring good prices at the market, no matter whether the ear is true to type or the wool grows on the nose or not. So, to the practical market breeder, the writer counsels, seek vigor, build constitutions, encourage health and thrift and the profits will be sure.

SELECTION OF THE JWES.

Pure-bred ewes may be selected much as the ram is, avoiding overgrown individuals, and seeking for uniformity of type and evidence of perfect health. In buying any sheep look well to the skin, that it be pink in color and the fleece bright and elastic, for a pale skin and sunken fleece are sure indications of lack of health and should invariably be rejected, no matter how good the blood or breeding. The grades that are to be made the body of the flock may be of Merino foundation, with excellent expectation of success. If these are not to be found near at home, they may often be bought of good quality at the great markets when discarded by the ranchmen. Usually ewes are sent to market because of their age and beginning lack of teeth so that it is not profitable 
to retain them for more than two lamb crops on the farm. They will thrive for that time and having saved the best of their ewe lambs, there is thus laid the foundation of a useful grade flock, while the mothers may be fattened and sent back to market.

While foundation ewes may be had from the markets, coming thence from the great Western ranges, it should not be overlooked that the native stock is generally better and to be preferred, when available. Western ewes having never been exposed to parasitic infection, are healthy, true, but when brought to Eastern farms and then exposed to these dangers, they prove less resistant than natives. The climate of the Eastern states is worse than they are accustomed to, and their breeding is apt to be uncertain. In no case should one buy ewes with perceptible Mexican blood in them, as these sheep readily revert to a very fixed and stubborn type, useful on the desert, but too primitive for good farm sheep husbandry.

It is unwise to select ewes shearing too heavy fleeces. A moderately heavy fleece betokens the stronger sheep with greater feeding capacity. Select that sort. Choose the short-legged ewes, with good backs, and as thick as you can find them.

The best time of the year to stock a farm with sheep is in the early fall. Getting the ewes home then, you have time to make their acquaintance while work is not crowding on the farm. Then you can see to the mating, and during the first winter things will go as you plan, 
and you are certain of one good lamb crop. Your troubles will not begin for six or eight months. They need not begin at all if you will observe carefully some rules for avoidance of parasites, to be laid down later.

\section{GETTING HOME WITH THE FLOCK.}

The writer remembers with delight the day when he drove to Woodland Farm his first flock of ewes. It was a fine sunny day in November. The sheep were well selected and round and plump, all young ewes. They traveled willingly along the country road through a quiet neighborhood where great oaks overarched the way and stopping now and then to browse the green grass among the purpling wild asters.

The writer was but a boy then, newly wedded filled with high hopes and dreaming brave dreams of the future. The young wife met him and together they drove home the little flock! Happy beginning it proved to be, though many lessons remained to be learned and many discouragements to be fought through, ret the coming of the flock meant the beginning of the upbuilding of the old farm and of the fortunes of its owners.

\section{IMPORTANCE OF DIPPING.}

When the flock comes home the first duty is to give it a thorough dipping. There are two reasons for this: the one that there may be ticks upon the sheep; the other because of danger from scab germs. Any sheep shipped by rail 
or penned in stock yards or railway stock pens is liable to be infected with scab germs. One or two scab insects on a sheep may multiply until the entire flock is scabby in a few months and entail great suffering upon the sheep and loss upon the owner. Prevention is easy and cheap, though cure after the disease has progressed far is harder. Another reason for dipping is the sheep tick. This is a common pest upon farms and greatly interferes with the thrift of sheep, while it is entirely preventable, and in truth upon the farm of the writer with a thousand sheep there are years when not a single tick is to be found. Sheep ticks so far as we know inhabit no other animals and once rid of them you will remain rid of them unless you buy infested sheep or carry ticks upon your own clothing or they are brought by shearers.

It is very easy and inexpensive entirely to rid a flock of ticks and as easy to prevent the attack of scab.

\section{THE SCAB GERM}

This is a minute form of parasitic insect too small to be easily discovered with the naked eye, which by burrowing in the skin, or, rather, by irritating the skin and causing it to form a crust by its own exudations beneath which it burrows, greatly afflicts the sheep, causing loss of wool, intense itching, loss of flesh, and in the end frequently brings death from the result of the distress and emaciation consequent upon its disturbance.

The scab germ multiplies with fearful rapid- 
ity, each female laying in two or three days 15 eggs, of which ten will hatch females and five males. These eggs hatch and soon mature insects begin laying eggs. Gerlach, the German authority, says that in 15 days one female will become the mother of 15 , after 30 days of 150 , after 45 days of 1,500 , after 60 days of 15,000 . Up to this time there has not been much seen of the result of the disease, but here begins the wholesale onslaught of the legion upon their hosts, for in 75 days there are 150,000 , and in 90 days $1,500,000$ ! Now let them alone for a little longer and the result is sufficiently terrifying.

The symptoms of scab are first the uneasiness of the sheep, which reaches around to the affected part (that is apt to be on the shoulder, neck or side, though it may appear in almost any part, but wherever it appears it causes intense itching) and bites at the wool or paws with its foot trying to scratch the spot. If now you will carefully examine the animal you will find under the wool at this spot of infection the skin whitened and perhaps exuding a watery secretion. One can not with the naked eye see the scab insects at work. A little later this spot if untreated becomes a veritable scab and the adjacent regions are attacked. It rapidly spreads throughout the flock, the affected sheep rubbing against posts and racks, dislodging mites that fasten in turn upon other sheep.

To cure scab thorough dipping is necessary. To prevent it all sheep should be well dipped after every railway journey or exposure in in- 
fected yards or pens. Dipping for prevention is cheap and easy. Dipping for cure is not so much harder. The main thing is to dip, and dip thoroughly.

\section{THE DIPPING VAT.}

This should be a simple trough of wood or metal or concrete, 16 inches wide, 4 feet deep and as long as one wishes to build. The shorter the vat the slower the process of dipping, as the sheep when scabby must soak for two minutes. For a farm vat a length of 10 or 12 feet will be ample, as time can be allowed them thoroughly to soak. The vat must be narrow so that the sheep can not turn around in it. It must be deep so that each sheep can be plunged clear in all over so that no spot will remain untreated. It is not necessary to lower the sheep into the vat or to raise them out again; they may as well be thrown in or made to jump in at one end, and that end of the vat should go down perpendicularly; at the other end there must be a gradual incline up which they can walk. For a small flock the bottom level of the vat need not be more than four feet long, with an incline beginning there and running gradually out to the level and to a draining platform from which the drip should be collected and discharged into the vat again. A width at the bottom of 6 inches is ample, as only the feet go clear down and the less width the less liquor is required to charge the vat. In case there is genuine and serious affection of scab, the sheep should be held rigidly in for two minutes, and 
in that time the head should be immersed briefly twice. If there is only suspected infection, however, and not yet any outbreak, the sheep may be run through as rapidly as convenient, being only sure that each one is completely immersed in the liquor, for they will remain wet for 24 hours at least after emerging from the dip. In a practice of many years the writer has never had scab break out in a flock thcroughly dipped once by simply running the sheep through. There are other essential conditions to be observed however, which will be mentioned now.

The dip should be hot. This does not mean warm, nor boiling, but as hot as the operator can endure to plunge in his bare arm. It is better to test the temperature in this manner than by use of a thermometer. If the latter is used a temperature of 110 deg. Fahrenheit will be about right, but the bare skin is the best thermometer.

The water used must be softened or "broke." To do this use ordinary concentrated lye, enough to make the water a little biting and give it an oily feel like soap. This is an inexpensive process.

The dip, whatever it is, must be used of good strength. There are various good preparations in use, most of which are effective if used of sufficient strength.

On the farm of the writer the coal tar preparations are used almost always, because ther prove effective and cheap, and are pleasant to operate with. They are healing to the skin and 
effectually dissipate any tendency to eye disease and are sure death to all forms of insect life whatever. These coal tar dips are given various names as "Zenoleum," "Naptholeum," "Daytholeum," etc., and are similar in composition and effect. The directions often say to use them at a strength of 1 to 100 , that is of one part of dip to 100 parts of water; this is not safe in combating scab, and as the cost of dipping is mostly in labor, the writer always uses them at a strength of one to forty, and has had no failure to cure every sort of parasitism and has never injured a sheep by its use.

In truth, one winter when scab broke out among some undipped sheep (that had been dipped in Chicago, but imperfectly) and the farm flock became infected, we dipped all in the middle of winter, turning back to the old quarters, and cured each case effectually, so that there has never been a reappearance of the disease upon the farm. 'The dipping was repeated in ten days to give chance for eggs to hatch.

This dipping so thoroughly also eradicates ticks which is no small matter.

\section{RFGULAR DIPPING OF THE FARM FLOCK.}

While new sheep added to the flock should be dipped whenever they arrive, barring exceedingly cold weather the regular flock needs its annual bath, and this should be given immediately after shearing, when ewes and lambs may all be dipped at a nominal cost. It takes nearly a gallon of liquid to dip a vearling of 
medium size with its fleece on, but to dip a shorn sheep takes not more than a quart, and the little lamb a small amount. This annual cleaning up prevents ticks getting foothold and heads off a lot of other troubles, such as sore eyes and mouths, canker of teats, and sheep lice.

It is not a troublesome operation to dip a flock of sheep. The water should be conveniently at hand and some means of heating it. An open kettle of 30 to 40 gallons capacity will serve if nothing else is convenient; red hot irons may be thrown into the tank to heat what is left from a previous dipping; there should be a large pen to hold the sheep and a small one close to the tank for a catching pen. Just at the end of the tank there may be an incline about 3 feet long covered with smooth sheet metal, and this may be greased so that when a sheep steps on it or is lifted upon it, it will easily slide down into the plunge.

A force of five men, two of whom keep the dip mixed and replenished, and three of whom put in and take out sheep, will readily dip 100 in an hour, though if they have their fleeces on they should drain for a longer time than would make this practicable. It is not often necessary to assist the sheep to climb out, but there should be one man ready and watching with care to see that all are fully submerged and none stay in too long. The writer has never seen pregnant ewes, handled with care in the dipping vat, abort their lambs, and has frequently dipped 500 without killing or injuring one.

The cheapest tank is made of galvanized iron. 
The best is made of concrete, which will endure forever if rightly made.

\section{SUMMARI OF DIPPING.}

Dip every sheep when it comes to the farm as soon as it is rested, especially with care when it may have come by rail.

When scab infection is suspected, but none is visible, dip once by simple and complete immersion in a dip hot and strong enough.

When scab is already in evidence let the affected sheep soak in the dip for two minutes, first having rubbed and loosened up the scabs. After ten days dip again; always turn freshly dipped sheep into their sheds so that they may rub their wet fleeces against the wood work and disinfect that.

Dip the whole flock every spring if there are ticks, immediately after shearing, being sure that no sheep or lamb escapes.

After the flock is clean it will remain clean if newly bought sheep are dipped before being added to it. There is no necessity to dip a clean flock.

At shearing time should the owner shear his own sheep and there be but two or three ticks to each animal he should cut them in two with the shears and dip the lambs.

There is no more need of having ticks on a sheep farm than there is of wolves.

FALI, TREATMENT OF THE EWE FLOCK.

The ewes being brought presumably to new and fresh pastures and rid of their vermin 
thrive admirably. If grass is not abundant they ought to have a little extra feed at times as it is Nature's way to then make them gain. A field of rape in which they may run, alternating at their pleasure with grass, makes them improve rapidly. Pumpkins fed on grass, seeds and all, are excellent for the ewes. Not only are the pumpkins good feed, but their seeds, besides being nourishing, have in them great medicinal virtues. Pumpkin seeds are efficient vermifuges. One of the best treatments for tape worm in the human subject is the infusion of pumpkin seeds. Worms destroy more sheep than dogs do, and it must be the constant study of the shepherd to avoid them.

The reason for desiring the flock to thrive at this time is that it is near the mating season, and if the sheep are in fine, thrifty condition, the ewes will the more rapidly conceive and drop a greater number of twins.

Yet another reason is that a sheep which starts into winter in good thrift comes through much stronger with less feed than one that starts in in poor flesh.

A handful of grain fed in October or November is worth a peck of feed to a thin ewe in January not that the flock should be neglected later on, but it is essential that sheep should enter winter well fortified and strong.

\section{MATING.}

Before the mating begins one should carefully go over his flock and assort the ewes. 
Ewe lambs must be taken out and none bred that are not past a year old. Old ewes that have lost their teeth and are evidently not quite able to go safely through the winter and nourish well their lambs, are better consigned to the fattening pen. At least there should be a mark put upon them that will indicate their condition, so that they may be given extra care and attention. Quite often with such ewes it is most profitable to breed them and by careful feeding keep them as strong as you dare till lambing time, after this to give them a large allowance of grain, ground if need be, so as to push them with their lambs, and they will often make as good lambs as the other ewes and be themselves ready to follow their offspring to market a few weeks after the lambs have left them. A suitable mark for these culled ewes is to clip off the end of one ear.

Yet another thing for which to search, is a spoiled udder or a ewe without perfect teats. Quite often such ewes are found, and to have them drop lambs without ability to suckle them is to entail great disappointment and trouble on the shepherd.

There is a temptation to breed the young, immature ewes, particularly if they are well grown, but it is wiser not to do this, as it leads to the steady decrease in size of your sheep, and by reakening the ewe's constitution because of the heavy drain upon her, you make her the more liable to attacks of parasites, 
those foes of the sheep and shepherd that never can be forgotten with safety.

\section{PUTTING IN THE RAM.}

The ewe carries her lamb from 142 to 150 days, or, roughly, five months. It is well to so time the putting in of the ram as to bring the lambs at the season when they will best fit in with your scheme of management. Much depends here upon the breed under consideration, for it is natural for the Dorset and the Merino to drop their lambs very early, so that they may be mated with the ram in September, when the lambs will come early in February, or if bred in August they will come in January, or in July to have them in December. With Shropshires it is unusual for lambs to appear so early as December or January, though the middle of September is an excellent time to mate them; with Southdowns the same time will serve, though they naturally lamb later, and with Cotswolds and Lincolns it is unusual for lambs to be born before March or April. If the shepherd has good quarters for his flock he may as well try for some early lambs; they will serve to occupy his time in winter, and coming then when he has leisure, he will lose but a small proportion of them. Winter lambs well nourished in infancy make much stronger and better sheep than late lambs, as they go on to grass so big and lusty as to defy many of the evils that attack later lambs.

MANAGEMENT OF THE RAM.

The ram during the summer days should have 
the run of a small lot with access to shade, with abundant food, yet not too much, and with company of other rams or of a few wethers, or some ram lambs or even with a few ewes running with him. He should have careful attention that he remains in perfect health, especial care being taken not to put him on a piece of infected grass where he may develop parasites. Before the breeding season he should be entirely separated from the ewes, and if not in strong condition, given a regular feed of oats and bran or some similar feed twice a day, not enough to fatten him, but to put him in vigorous condition.

It is wise not to ever turn him with the ewes, but better to bring them to him each morning early while it is yet cool, penning them in a small pen so that there is just room enough for him to move about readily among them, and where they can not easily escape you when you desire to catch some of them.

After the ewes are brought up, let him come in with them, and he will soon single out one that may be in heat. Allow him to serve her once only and immediately put her out, marking her at the same time so that you will know that she has been bred. It is wise to use a different color in marking each week, thus all the ewes that are bred the first week will be marked red, all the next week blue, the third week yellow; the fourth week black, the fifth week green and so on. 'This marking is done with a brush and a daub of paint, on the back of the head or on the shoulder is a good place.

After the first ewe has been taken out, the 
ram will proceed quietly to search for another. Unless he is a very vigorous ram, it is unwise to allow him to serve more than four during a morning, and if a large number seem to be in heat, it will be well to get them up again after sunset in the evening. The ram has an exceedingly vigorous reproductive system, and has power to impregnate more females than most animals, even though his work is confined to a short period each year.

The ewes that are served and put out should be put by themselves and not returned to the flock for three days, else they may be still in heat and receive unnecessary attention from the male. One service will as surely impregnate as more and will beget stronger lambs.

Managed in this way a ram will easily care for 40 or 50 ewes and many serve 100 if he is unusually strong and vigorous and well cared for. He should be kept quiet all day, in a cool place, and well fed on stimulating food such as oats and bran with clover hay.

One advantage from this way of managing ewes is that one will know those that do not take the ram at all and can put them out of the flock, and by giving them a little extra feed, they will soon fatten, when they may be sold.

There is a practice not very common among shepherds of forcibly holding ewes that persistently reject the ram, and allowing him to serve them. They will not often conceive from this service, but it occasionally causes them to come in heat naturally in from ten days to three weeks. Some early lamb breeders make consid- 
erable use of this practice. It can do the ewe no harm in case it is unsuccessful.

CARE OF THE PREGNANT EWE.

Perhaps the greatest stumbling block in the way of the inexperienced shepherd is in the care of his ewe flock during pregnancy. Either he feeds them too well, or on unsuitable foods, or he deprives them of air and exercise, or he goes to the other extreme and lets them brave the storms without enough food. Either condition will surely be fatal to his fortune, though of the two extremes the worse is that of too much food and no exercise. Such a course is surely fatal to his hopes of a large crop of strong lambs.

If one would have success with these pregnant ewes he should consider their condition in a state of nature. Then they roamed the hills, selecting the higher points as places to sleep; they sheltered beside rocks or under pines. They were not in large flocks and found sufficient food as they were not restrained by fences. They had abundant exercise and always fresh air. Doubtless when their lambs came they were very strong and vigorous, able soon to run beside their mothers. Under ranch conditions today lambs are born very strong, and it is rare to find one so weak as to be unable to suck without aid.

The writer remembers vividly his first experience with lambing ewes. The first winter he let them have the run of a pasture, with shel- 
ter, fed clover and corn stover, and the result was a good lamb crop. A few of these lambs were so remarkably promising, one selling for $\$ 18$ at weaning time, that he was encouraged to attempt to do much better the next year. That winter proved to be quite cold and stormy so he kept them rather close. Having learned the value of wheat bran as a bone and muscle builder, he fed these ewes about all the bran they wanted, and they consumed a great deal, with clover hay.

The lamb crop came early, and the lambs were strong, being the product of hand coupling with a vigorous sire. The difficulty was in the enormous size of many of them, some being so large of bone that it was nearly impossible for them to be delivered at all. One Shropshire weighed 17 pounds at birth! Its mother died socn after its delivery, and the lamb itself was lost through unskillful feeding. The net result was a small crop of magnificent lambs secured at a cost of great labor and pains.

The next year an old friend and shepherd counseled him to adopt a radically different policy. This was to allow the flock to run in the pasture, sheltering in open sheds and under the trees, and subsisting solely on coarse forage such as corn stover and oat straw. Having in the barns a great number of lambs that were being fed for fattening, there was some excuse for neglecting the ewes.

Unfortunately ewes in winter time because of their long fleeces, appear to be in good condition when they are not, and the writer had 
no idea how very thin in flesh they were becoming until lambs started to drop in April. Then his troubles began. The lambs came strong enough, as a rule, nor were they too large to be delivered easily but the ewes having been poorly nourished, had no milk for them, and would not own them at all. The truth is that there is a direct connection between the milk glands of an animal and the part of the brain where lies love of offspring, and in the sheep at least it is rare to find mother love where there is no milk to go along with it.

The result was that the writer was put to his wits' end to make the ewes own their lambs and to try by good feeding to bring them to their milk flow. Many lambs were lost, and the whole result was disheartening.

The simple truth is that pregnant ewes must have so far as possible natural conditions. They must have enough food, and that of a suitable nature properly to nourish the growing foetus without stimulating too much the development of bone. They must come to lambing in good heart, what the farmer would call "fat," but not according to the butcher's standard. They must have abundant opportunity to exercise and to get fresh air. Thus treated their lambs should come as strong as wild things and give little trouble. It is the natural thing for a lamb to be born strong, to live at birth, since all its ancestors have done the like since lambs were born into the world.

There is danger in well bred ewes highly fed upon such foods as wheat bran and clover or 
alfalfa hay that the lambs may have excessive bony development, and it is not now the practice of the writer to feed much bran before weaning, but to give instead bright, sweet corn stover and alfalfa hay. Too much alfalfa hay alone wil! sometimes make the lambs rather large at birth. If the coarse forage is not abundant and of excellent quality, the shepherd should feed a small daily allowance of grain. A mixture of corn and oats may be used, which should be fed in wide flat-bottomed troughs, so that the ewes can not rapidly swallow it as they will when fed in V-shaped troughs.

A run to a blue-grass pasture is an excellent thing and if the grass is permitted to grow up in the fall and lie meaten, no small part of the sustenance of the flock will come from that. A sheltering bit of woodland, in which they may wander, affords shelter and amusement, and well repays the ground on which it stands.

While the flock should be out of doors every fine winter's dar, yet the shepherd should have his charges in mind and see that each ewe comes to the barn before storms break, and always the flock should be shut in at night. Yet unless the weather is very severe they should have much fresh air in their night quarters-a large opening on the leeward side is the best provision. 


\section{CHAPTER V.}

\section{CARE OF THE EWE AND YOUNG LAMB.}

THE EIVE BARN.

A breeding ewe requires about 12 square feet of floor surface. There should be provided in the ewe barn movable feed racks, long and narrow, of such type that they will form partitions wherever needed. These racks are best made 24 inches wide, 36 inches high, with a tight bottom about 6 inches up from the ground. The sides about this bottom may be of 6 inch boards, forming a shallow feed box. On this foundation will be nailed, vertically, slats $1 / 2$ inch thick, 4 inches wide and 30 inches long. These slats may be placed 7 inches apart, so that the sheep can thrust their heads clear into the rack to feed. There will then be much less loss of feed than if the slats are placed close together, for in that case the ewes pull all the hay through the cracks and drop most of it under their feet. There will be a little dust get into the wool of the necks in feeding in such a rack, but it is a trifling damage compared with the loss of forage in any "feed-saving" rack. 
After using many forms of racks, the writer now uses these in preference to any others, for in them may be fed grain, bran, silage or any sort of hay.

The ewe barn must have provision for most ample ventilation. That is best accomplished by having on two sides clear across the barn

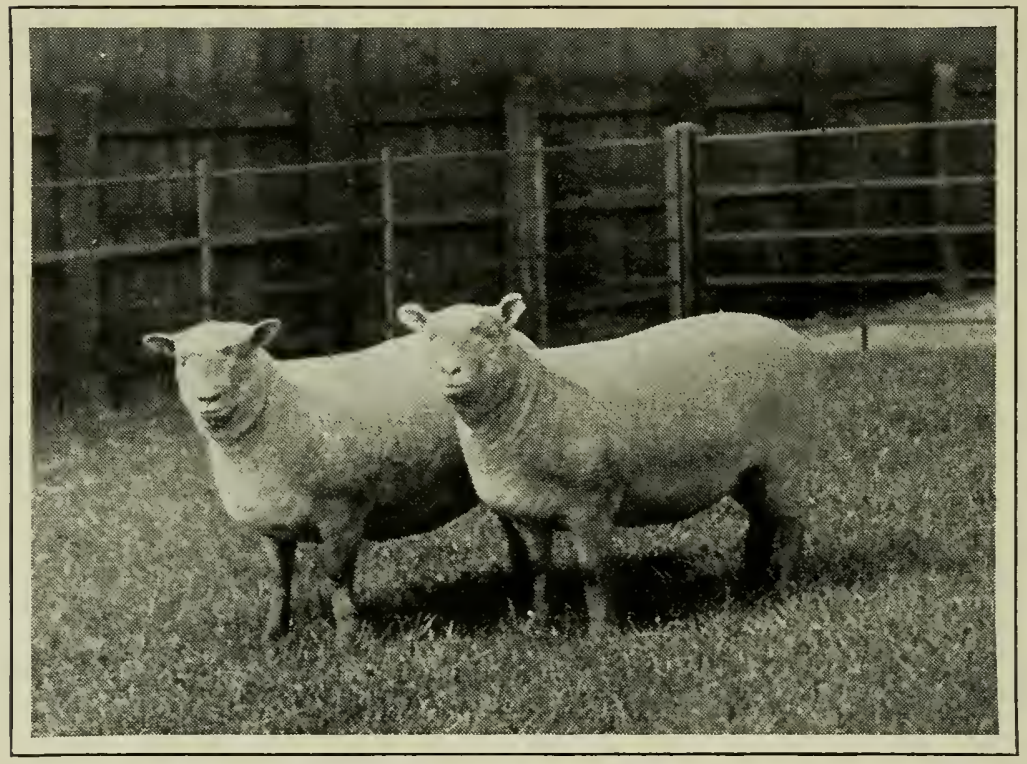

SOUTHDOWN EWES

a system of doors so arranged that they are divided in halves horizontally, the lower part of the door swinging as an ordinary gate swings, the upper half hinged at its upper edge and lifting up to a horizontal position, upheld by wooden props or pendant chains.

By means of these upper doors the ventilation 
may be made so thorough that the air will be practically as good within the barn as outside, or in colder weather one side may be completely closed and the other, to leeward, opened or in very cold weather all may be closed tight.

It will be disastrous to confine the sheep in a poorly ventilated building. Loss of thrift, colds and catarrh will surely result.

In England sheep are almost never confined to buildings at all. Their usual mild winters make outdoor feeding practicable with them, whereas it is not so with us. We must feed in racks during the time that they are hurdling off turnips in winter and much of the loss of thrift and character of English sheep bred here is owing to unskillful wintering in poorly ventilated barns. During the winter season the shepherd has opportunity to get well acquainted with his flock. He should learn to know each ewe by her countenance; and she should learn to know him and to know so little of evil of him that he can approach any one and catch her without difficulty and without frightening her. A shepherd's crook that will catch by the hind leg is useful in the sheep fold, though I prefer for ordinary use the old-fashioned crook that catches by the neck. Any blacksmith can make in a few moments a crook of an old horse-rake tooth, set in a long wooden handle. It should be so shaped that it will with a little pressure slip over the neck of the ewe, widening at the opening considerably to make it easy of use, and the end should be turned over in a little coil so that it can not accidentally wound the skin. 
Before the lambs are due it is well to turn each ewe up on her rump, using her gently, and with shears clip the wool away from the udder; particularly the little locks that might be seized by the lamb when searching for the teat.

Before the lambing season the shepherd should provide himself with some little panels, made of light wood, like doors, each panel $36^{\prime \prime}$ high and 48 " long. Two of these panels should be hinged together at the ends so that they may be folded together and laid away or opened in the shape of the letter L. The use of these is to make little pens in which to place ewes about to lamb, or newly lambed, to prevent their lambs straying away and getting mixed through the flock. Thus many lambs will be saved that other'wise would be lost and much of the usual vexatious work of the shepherd avoided. To use these panels, one is opened at right angles in the corner of the lambing room and by aid of hooks fastened at the free ends to the wall thus making a pen $t^{\prime} \times t^{\prime}$. As it is tight, the lamb can not creep out, and the ewe being unable to see out is made more tranquil. When there is need of another such pen it is set up alongside the first one and thus on until a row has been erected across the end of the building. If there be need, another row can join these.

The observant shepherd can usually foretell the advent of a lamb, for the ewe shows by her appearance and her actions that she is expecting it. Because of her instinct, indeed it is not unusual to see a ewe hunting anxiously about for her lamb before it has been born at all! It is 


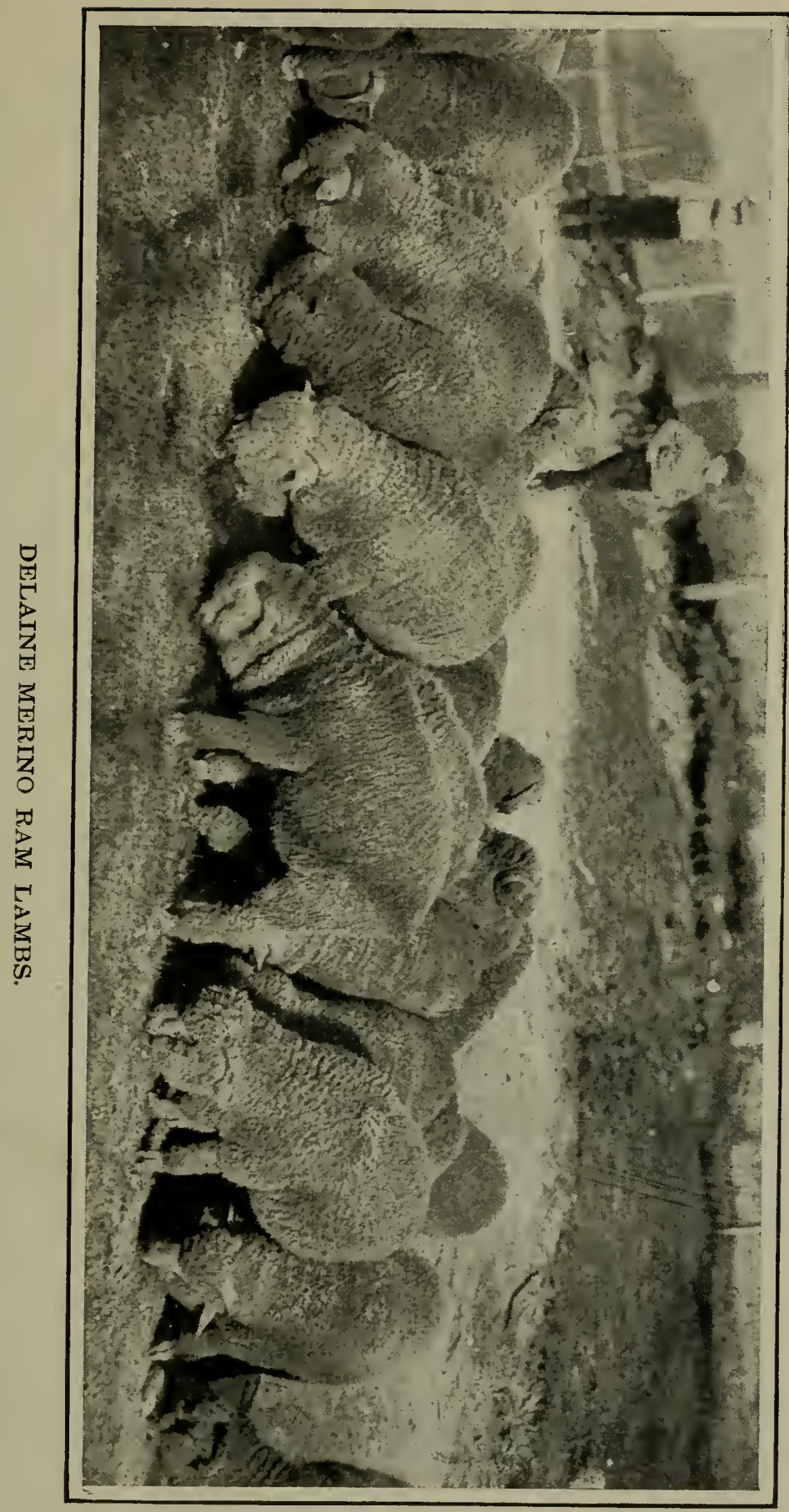



wise to place her by herself before this event occurs, if it conveniently can be done.

\section{CARE $\Lambda$ T LAMBING TIME.}

There should be small difficulty in the ewe delivering her lamb if she has been rightly fed and treated. There will probably be no occasion for interference of the shepherd, yet he should be watchful, and when she has been in distress for some time without effect he should not hesitate to go to her assistance. The difficulty may be one of wrong presentation. Naturally the lamb coines with front feet first, and nose just between them. Even when the presentation is right the shepherd may be of great help sometimes, if the lamb is of large size, by gently manipulating the parts, pulling a little at the lamb and pushing the external parts of the ewe back until the head is free. 'Then the nose may be wiped so that the lamb can breathe and in a moment, after the ewe has again begun her labor, you may gently draw the lamb outward until the slioulders are delivered-the hardest part. I usually leave her then, for the hips and hind legs come away readily, and the ewe generally gets up at once and seeks her lamb and proceeds to lick it and caress it with her tongue. It should soon try to stand and in about 15 minutes will try to suck. If it finds the teat without aid you may call it half raised.

Usually it is well to help the lamb to its first meal, especially if the ewe is young, and it is her first born. The easiest way to do this is to gently set her on her rump, as though you were going 
to shear her, kneeling down behind her and with her shoulder's resting against you. First start the milk from her teats, then taking the lamb with the right hand (the left arm being under the ewe to support her), lay it down on its side and opening its mouth insert the teat, when it will usually begin to suck immediately. Let it get a pretty fair belly full and its chances are bright for coming on in good, strong fashion.

The shepherd should observe whether it afterward goes to sucking on its own account, and if it does there need not be manr slips between that lamb and a ten dollar bill, if it is born right!

Supposing there is a wrong presentation. The shepherd is fortunate if he has a small hand, for it is his duty to help put things right. We can not here give details of how this is to be done, but knowing the natural presentation the shepherd should be able to study it out for himself. He must carefully grease his hand with lard or vaseline and avoid so far as possible any rough treatment or injury to the delicate parts. The writer has taken several lambs away with hind feet first without difficulty, but should the head be turned back it must be straightened before delivery is possible.

There will be much more difficulty with young ewes than with older ones, so that the inexperienced shepherd is wise if he begins with ewes most of which have lambed once or twice before they came to his care.

In very cold weather the lambing barn should be made as comfortable as possible, without depriving it altogether of fresh air, and even then 
when twin lambs are born there may be need of assistance or one of them may perish before it is made dry and given milk to supply inward heat. It is an excellent plan to have at hand a tub or half barrel; a salt barrel sawed in two serves well and in this have a jug of hot water. The lamb may be laid in this tub and it covered with a blanket until its mother can give it her attention. Or a chilled lamb, if only slightly chilled, may be warmed in this manner. An excellent plan and simpler if the shepherd is at hand when the first of twins is born is to lay it in a tub on two or three inches of wheat bran and cover it all but the nose with more bran. It will keep as warm as toast there and the bran will help absorb moisture. Then when it is given to the ewe she will lick off the adhering bran without injury to herself.

Supposing that through some accident the new-born lamb has gotten thoroughly chilled; the best manner of warming it is by immersion in water as hot as one can bear his hand in. This will soon become cooled and more hot water should be added, taking care of course not to scald the lamb. When warm and revived it should be wiped dry and taken to its mother and held till it is supplied with her milk. The writer has revived in this manner lambs seemingly dead. It is not wise to give it cow's milk if it can be avoided and if it is necessary the cow's milk should be diluted with some quite warm water. Some shepherds give a drop or two of whiskey to a chilled lamb and it may sometimes prove beneficial. 
The next day after the lamb is born the ewe should be milked clean. The shepherd should then observe whether the lamb is taking her milk all right, and if there is much surplus he should milk it out every day clean until such time as the lamb can use it. This is especially necessary with Dorset ewes and some other breeds occasionally need attention. It is not well for the lamb to take in the milk first secreted after being retained stagnant in the dam's udder for an undue length of time. Such large milking ewes while troublesome raise the finest and most profitable lambs in the end.

Occasionally a young ewe will not own her lamb or an older ewe may neglect or disown hers. Generally, if the lamb is put with her in a small pen and helped to get its rations for a few times she will own it. If she persists in her neglect she may have her head fastened into a pair of small stanchions so that she carn eat but not get away from the lamb nor attack it, nor readily prevent its sucking. These stanchions may be made of two pieces of $1 \times 4$ pine driven into the earthen floor, and the tops held together by a short board nailed on. There is no cruelty about this practice and it is generally effective when persisted in for a few days.

Occasionally there will be a ewe whose lamb will die and leave her with an udder filled with milk. This gives opportunity to change to her some twin lamb whose mother would be better for the relief. To accomplish this transference the best plan is to remove the skin of the dead lamb soon after its death and slip it over the 
living lamb. It may be pulled off as a stocking is removed and rubbed with a little salt to dry it and at once slipped on to the twin lamb with the feet thrust through the holes where the former lamb's leg's were. Introduced now to the mother of the dead lamb, confined with her in a small pen, it is not often that she will refuse to own it at once. Ewes know their lambs en-

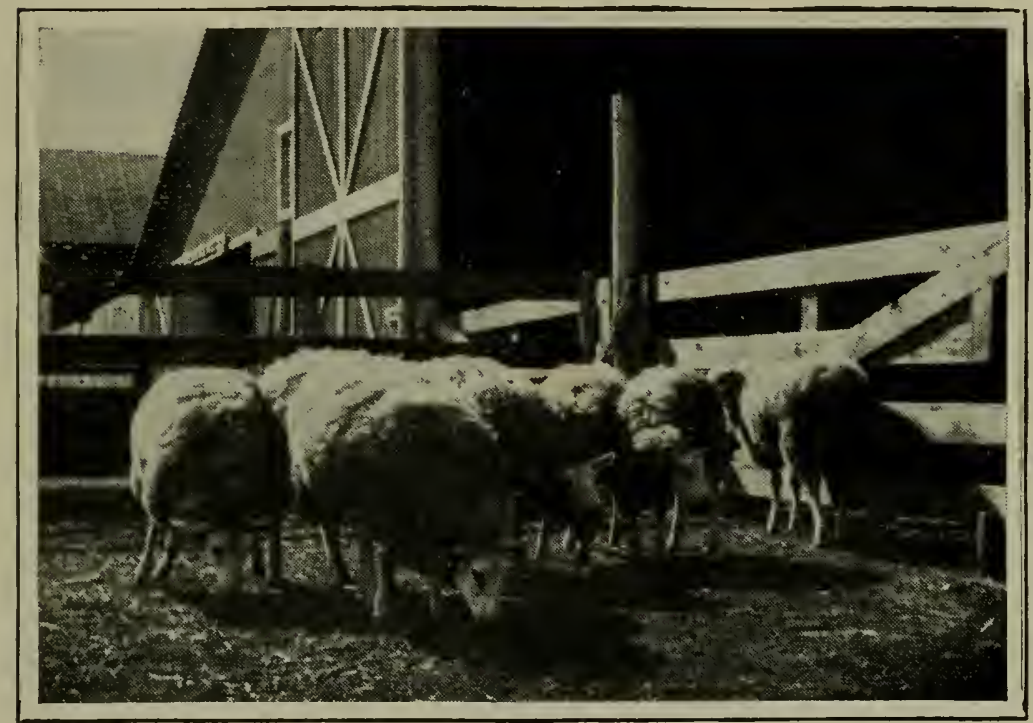

A BUNCH OF NEBRASKA LEICESTERS.

tirely by scent, and thus the odor of the skin tells her that it is truly her own lamb that is with her. This skin may be taken off after a few days.

It is not good shepherding to permit a ewe to be without a lamb sucking her when there are lambs enough to go around, and usually there will be so many twins among ewes of the mut- 
ton breeds that there are enough lambs for all and perhaps 25 to the hundred over.

Occasionally a ewe will be found of so perverse a disposition or so undeveloped in udder or malformed that she will not raise a lamb at all. The cure for her is to cut off half of one ear, which is the "brand of Cain," and indicates that she is to go to the butcher as soon as fat.

There is a man in the West who sells for one dollar a receipt for making ewes own lambs, either their own or some others. Having paid my dollar I can testify that there is merit in his plan, which is to carefully wash the lamb, especially about the rump and tail and on top of the head, removing thus all trace of scent so far as possible. Next you are to catch the ewe and milk upon the head and rump of the lamb from her udder, rubbing it well over him, and lastly to put a handful of milk on her own nose and in her mouth. Then hold the lamb to her side and when it is sucking permit her to smell of it. Often this will succeed, but if she has lambed some dars previously the recourse to stanchions will be surer and less troublesome.

FEEDING OF THE EWE AFTER LAMBING.

If the ewe has been well nourished during her pregnancy she comes in with her lamb strong and has a well filled udder. At once when the lamb is born she must be turned away from the flock, and if the shepherd will give her the trifle of care that she really needs then, he will keep her by herself or in a pen with other ewes in her condition for a few days. During this time 
she should be somewhat sparingly fed with grain, or it may even be best to give her none at all, depending upon her condition. It is unwise to early force her to a milk flow in excess of what the lamb can consume. In a few days, however, she will need good food in generous amounts for the lamb will draw heavily upon her system for nourishment. She can not keep up her milk flow by eating alone if she is a large milker, but will decline somewhat in condition, even when well fed, showing that her flesh also turns to milk.

Bear always in mind two facts. Sheep are ruminating animals, accustomed by nature to eating bulky foods of moderate nutritive properties, and not accustomed to eating grain. Next, sheep have delicate digestions, easily disturbed by improper feeding, excessive feeding or sudden changes in the amount of feed given. Therefore make no sudden changes and least of all make at once a large addition of grain to her daily ration. In England ewes seldom taste grain at all, but eat instead grass, hay and roots, mainly swede turnips. Here, where roots are not so easily grown and fed (excepting in Canada and northern America), more reliance is put upon grain and with care in feeding it may take the place very well.

A sensible treatment of the ewe that lambs in winter is to keep her mostly on clover or alfalfa hay until after her lamb comes. There will be no need to limit the amount of hay that she consumes after lambing and then when her lamb takes all her milk and wishes more, begin feed- 
ing her a little wheat bran. For a week bran will suffice, gradually increasing the amount fed, then there may be added to it a little chopped corn or barley and a little later some oilmeal. A pound a day of this mixture will keep her in good milk flow and it must be gradually led up to for about ten days.

About the right proportions of this mixture are $100 \mathrm{lbs}$. of wheat bran, $100 \mathrm{lbs}$. of chopped corn and $20 \mathrm{lbs}$. of oilmeal. This with clover or alfalfa hay will push her to a very heavy milk How. If she is a large ewe she may consume more than a pound to advantage, as much as two pounds being consumed by some large Dorset ewes belonging to the writer.

If this feed is so gradually introduced to the ewe that her digestion is not disturbed nor her milk flow stimulated too much at first, there is small danger of overfeeding her, supposing that the lamb is to be pushed for early market. Her unselfish nature turns the feed quiekly into milk and little of it goes to nourish her own body.

It is much easier, however, to keep her in large milk flow if we provide succulent food at this time. Corn silage is easily provided and is as good for the ewe as for the cow. It should be made from well matured corn so as to develop its sugar and prevent an excess of acid from forming. Some complaint has been made of the effect of corn silage upon sheep, but usually the trouble has been that the feeders have tried to make it the main part of the ration. Tt should always be fed in connection with good sound dry hay and some grain. As corn silage 
from well matured corn has in it a good deal of grain when it is fed, the rest of the ration should be of wheat bran, oilmeal and clover or alfalfa hay.

In the northern part of the United States, along the great lakes, in Michigan, Wisconsin and northern Minnesota beside northern New York and New England and in all of Canada (besides Oregon, Washington and British Columbia) roots form a very important part of the ewe's ration. Roots have, indeed, almost created the Fnglish breeds of mutton sheep. They are safer to feed than silage and better. In England it is customary to grow turnips, mostly swedes, which are seldom pulled but are consumed on the ground on which they grow, being enclosed by hurdles and eaten off a block at a time. In very wet or bad weather some are pulled and carried to the sheep being fed on grass or in open sheds.

The use of roots is productive of great good to the ewe flock. They are succulent and start a natural milk flow, whereas grain naturally goes more to producing flesh and fat. There is no danger of the ewes consuming too many roots. They push her easily and naturally to a strong flow of milk that has very healthful properties. Ewes highly fed on grain often give milk that is injurious to their lambs. Of this there is no danger when roots are substituted in large part for the grain.

The shepherd who can readily grow roots has a distinct advantage over the one who relies upon dry hay and grain for wintering his ewe 
flock. Most of the best developed sheep, the ones seen at our fall shows, come from rootgrowing regions. Unfortunately roots are not very easily grown in the corn-belt and below, though mangels will thrive well to the southward.

Swede turnips form the bulk of the roots grown for sheep. They should be sown on productive soil, well prepared. The time of sowing varies with climates but usually early in July the seed should go into the ground. It is well to have the land ridged nicely and to sow the seed on the top of the ridge, which makes much easier hoeing' and thinning or "singling." In dry climates of course ridging must be attempted with caution not to get them too sharp and tall. Mangels are more productive than swedes but are not so rich and are unsafe to feed to rams. Carrots are more trouble to grow than either but are the best when grown.

Many distressing troubles come from sudden increase in the grain ration of the ewe after lambing. It is a very inducing cause of garget, or it may stop the milk flow altogether, or it may cause founder, stiffness of joints and great lameness.

\section{TROUBLES OF YOUNG LAMBHOOD.}

The lamb has his trials and dangers too. Supposing that he gets accidentally shut away from his mother for some hours, until he is very empty and she very full of milk, if then he gets sudden access to her he will usually die from the overburden of milk taken in. When the 
shepherd discovers that ewe and lamb have been separated for several hours he should catch the ewe and milk her nearly clean before allowing them to come together.

Then there are contagious sore eyes. These are caused by a germ. There are probably several kinds of germs that do the mischief, and the result is an inflammation and weeping of the eye with consequent distress and lack of thrift. The cure is fortunately easy. Taking some one of the coal tar dips, and diluting with water nearly as much as for killing scab, the head should be well wet and care taken that some of the fluid actually reaches the eye. It may be painful for a moment but it rorks a speedy cure. The writer has repeatedly cured this trouble by dropping a tiny drop of the pure dip, undiluted, into the open eye of the lamb. Tears start vigorously and dissolve it while the eyelid winking vigorously carries it to every part. The cheeks should be saturated also with dip properly diluted.

SORE MOUTH AND TEATS.

Quite often a contagious form of sore mouth affects young lambs and the sores are seen also upon the teats and udders of the ewes. These sores form scabs along the edges of the lips and pustules upon the teats. Often they become so troublesome as to cause the death of the lamb, more usually simply interfering with its thrift so much as to sometimes make it profitless. The writer has found this disease, which sheep writers usually spend so much time in describing 
and discussing, of the easiest possible control. Assuming that it is of germ origin, to rub off the scabs and wash the lips with strong solutions of coal tar dips and to treat the udders in the same manner has with the author in every case served to effect a radical cure. Quite often this disease breaks out upon the mouths of Western range lambs upon their arrival at an Eastern farm for feeding. The treatment is to rub off the scabs and apply the undiluted dip to the fresh surface. In recommending these coal tar products the writer wishes to be understood as meaning such preparations as are usually sold as "Zenoleum," "Naptholeum,". "Milk Oil," etc. They are much alike, really impure coal tar creosote, and most effectual destroyers of germ life and when used with discretion are among the best friends of the shepherd.

\section{FEEDING THE LAMBS.}

Lambs early develop a hunger for solid food and begin nibbling at hay and sampling ground feed or whatever is at hand. At the age of ten days they will begin seriously to eat ground feed. Advantage of this should be taken and the lamb encouraged to eat as early and as much as possible. During the early life of an animal nutrition is more perfect than later and the cost of producing growth is much less. Digestion is more perfect, the roung animal can consume more in proportion to its weight and it is more perfectly assimilated. A pound of flesh on the baby lamb can therefore be made at a much less 
cost than after he is older. Seeing that the young mutton commands by far the higher price it is plain that the earlier weight is put on the better so far as profit is concerned.

The practice in England is to have in the hurdles in which the flock is usually confined,

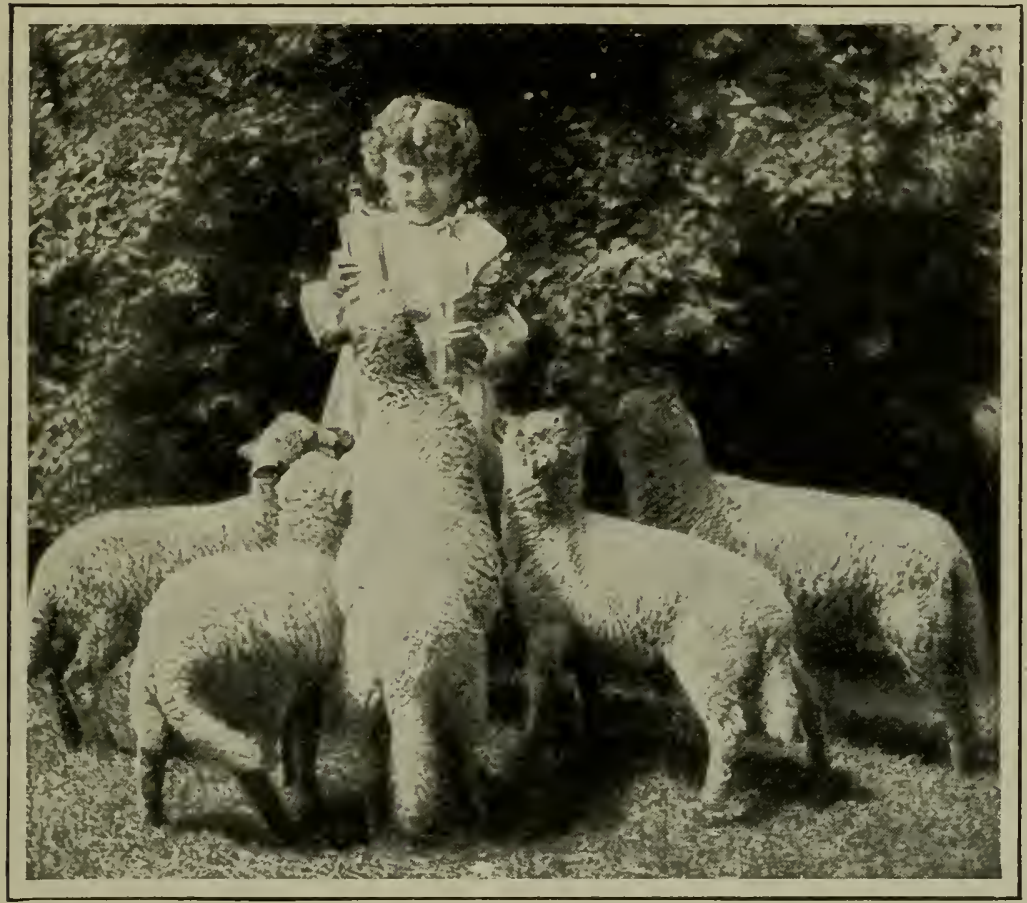

"MARY HAD FIVE LITTLE LAMBS."

"creeps" or openings wide enough to let the lambs slip through while restraining the ewes. These creeps usually have small rollers at the sides so that the lambs as they grow and nearly fill the opening may squeeze through without injury to themselves or loosening of their wool. 
Thus the lambs "run forward" to an enclosure of their own where they find fresh grazing of turnips or vetch or clover or grass, according to the situation and season, and in these small enclosures are kept troughs replenished regularly twice a day with some grain mixture. Finglish feeder's use great amounts of "cake," which is either of linseed or cottonseed. This cake is made at American oil mills where by pressure oil is extracted from the crushed seed. American feeders usually buy "oilmeal," or ground cake whereas our British cousins prefer to buy the actual cakes and break them on the farm into bits as large perhaps as hickory nuts, nr somewhat smaller for young lambs. English lambs come from the hurdles at the age of three or four months weighing 20 to $100 \mathrm{lbs}$. They will do as well in America, under right management, as the writer has frequently demonstrated in his own practice. The fact is that one must keep the ewes in any case and must feed them, so that there is a certain fixed expense connected with rearing the lambs. This expense produces a certain amount of growth; now by the addition of supplementary foods this growth may be greatly increased at very slight expense. The amount of extra food consumed by the young lamb to make an extra pound of growth will not cost more than one or two cents. To make a pound of g'rowth on him after he has left his mother will cost from $31 \%$ to 5 cents. Then too, the early growth is what brings the highest price. And again the lamb that matures very early and gets away to market escapes a hun- 
dred ills that lie in wait for the lamb that remains on the farm for nearly a year, so, altogether, the arguments are all for pushing the farm-born lambs as rapidly as possible by extra allowances of feed.

Of course lambs that are pure-bred and intended to stay on the farm to maturity must be fed a different ration from those that are merely to get fat quick and end a short but happy and victorious life at the market. Stock lambs need abundant food but no forcing. Their ration aside from their mothers' milk should be of oats and bran, with a trifle of oilmeal, clover and alfalfa hay, and in their ground feed there may be added a little fine ground bonemeal,--. the steamed bone or some odorless product to be chosen of course. There is small danger of overfeeding these stock lambs in their infancy; they will the earlier go afield and learn there to seek their subsistence in the form of grass and herbage. Corn should not be fed to them, neither to the ewe lambs nor the ram lambs, for corn mainly makes fat and fat impedes vital functions rather than helps. The ram lambs developed on corn are slow, sluggish, early losing their usefulness; the ewes developed on corn are uncertain breeders and often poor milkers. To develop bone and muscle and stamina in these stock lambs should be the aim and this is accomplished by feeding food rich in bone and muscle-making materials, of which wheat bran is easily among the first and oats comes next. They should have abundant chance of exercise too, which may be denied somewhat 
to the lambs that are to go fat to an early market. Then there should be constant watchfulness to avoid infection from parasites and if this is done the shepherd will have abundant reason to congratulate himself upon the splendid growth of his stock lambs.

\section{FFEDING FOR THE MARKET.}

Supposing now the lamb crop is mostly to go fat to market as soon as ripe. We will assume that they have been born in winter, which is the proper season for all lambs to be born on farms, unless one can get them in the fall, and that they have comfortable quarters and their mother's have been so well fed that they have an abundance of milk for them. Next there must be provided a small room or pen in which the lambs can go and the ewes can not. This place must be of very convenient access, so that it is really easier for the lamb to go in than to remain outside. This is because lambs have fleeting memories and are largely the creatures of opportunity. They will consume much more feed when it is right at their mouths than if they have to go even a few rods to seek it. This place, which we call a "creep," must be in a light part of the barn and if the sun can shine in all the better, for lambs are attracted by sunlight and greatly benefited by it. In truth some of the most successful lamb growers have glassroofed sheds for their use in winter and achieve thereby remarkable results.

This creep need not be very large. If it is 12 feet square it will accommodate 50 lambs 


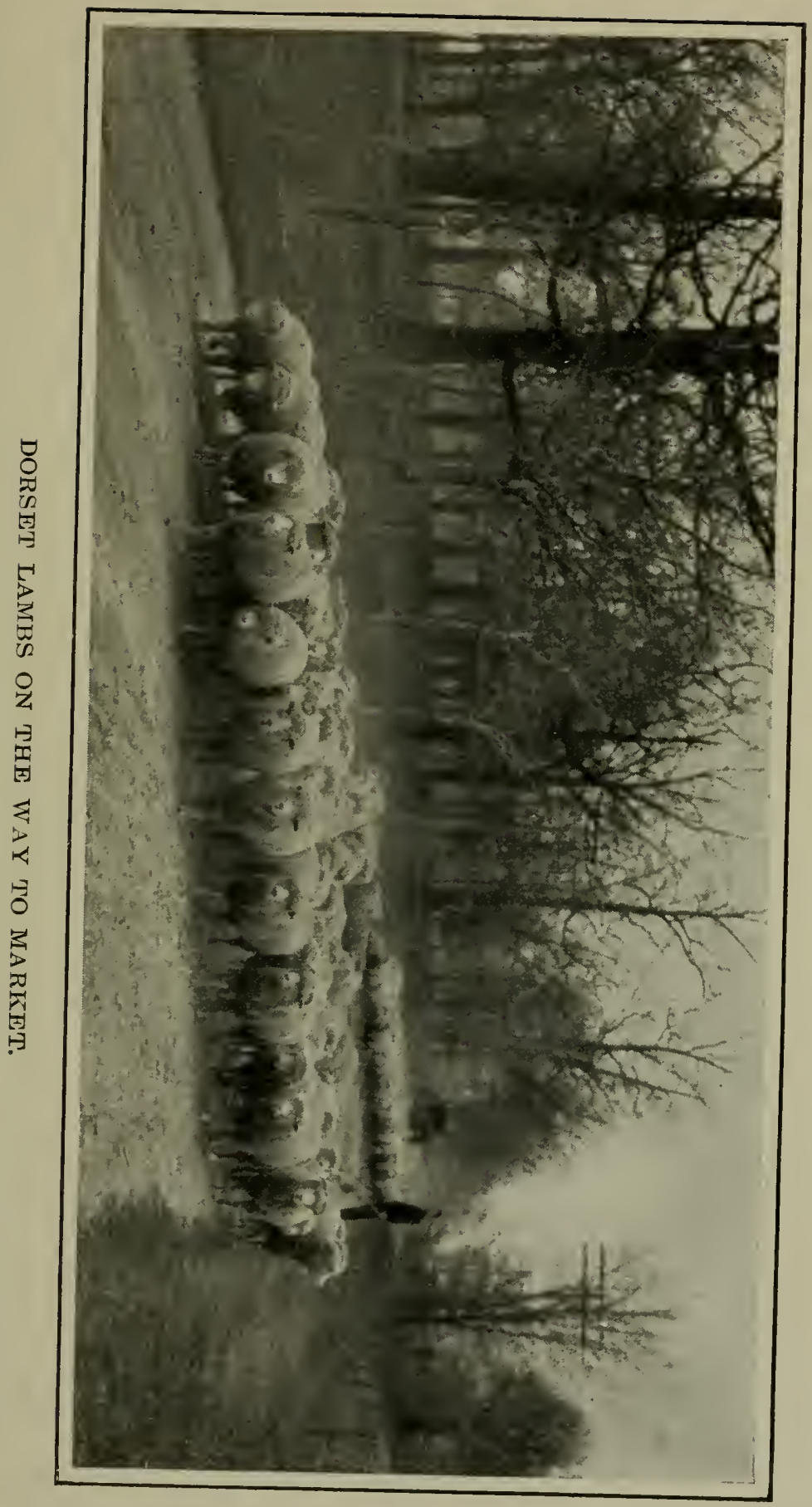



very nicely, as they will not all be in it at one time. It should be separated from the ewes' part of the barn by a fence of vertical slats, spaced about 7 inches apart, the slats with rounded edges. This will permit the lambs to pass in and restrain the ewes. After a time the lambs will need some wider openings and then if small rollers are put up to permit them to squeeze between all the better.

In the creep there must be some flat-bottomed troughs in which to feed grain and a hay rack for alfalfa hay, or clover if it is the best at hand. The troughs must be low to permit young lambs readily to reach them. As lambs delight to get into troughs with their feet they must be covered. To accomplish this let the end of the trough be a solid board 12 inches wide and extending up 12 inches above the sides of the trough, pointed at the end like the gable of a house roof and put on this two boards like an inverted $V$. This makes a steep roof to the trough and effectually prevents the lambs getting their feet into it.

This cover is readily lifted off when grain is put in. Attention to such small details as keeping troughs clean is essential to success in feeding lambs. Their sense of smell is acute and they discriminate sharply against anything but clean, fresh food.

The first feed to put into the trough may be wheat bran. Scatter a trifle in the bottom and sprinkle it with brown sugar. If the lambs do not find it readily, take one up gently, not to frighten him, and carrying him to the trough 
put a little of the sweetened bran in his mouth. He will get the taste and in many cases you can carefully put him on his feet with his head in the trough leaving him there. Once he gets a taste he will return and bring other's with him.

It is essential that the bran used be fresh. Cracked corn will be added to the bran; it also must be fresh and made of good, sound corn. It need not be cracked very fine. Better mix in a box or bin about 50 lbs. of cracked corn, 50 lbs. of wheat bran and $10 \mathrm{lbs}$. of oilmeal, coarse ground. If oats are available they may be added to this ration, ground at first, without changing the proportions of other things for oats themselves form nearly a balanced ration.

Feed this twice or three times a day, placing in the troughs about what will be consumed and when next feeding time comes sweep out and give to the ewes what may be left so as to always have fresh feed before the lambs. Never wait for them to lick out the last particle before offering them fresh feed.

You will soon be astonished at the amount the little fellows will consume and at the transformation in their appearance. The plump roundness of the baby forms is very beautiful and to watch them grow is a satisfaction and joy every day.

Of course there are other things that may be fed. Wheat middlings may make a small part of the ration; it is too floury for best results, as the lambs do not like it so well. Rye will serve a useful purpose, though it seems less palatable than oats or barley. Soy beans may 
replace the oilmeal and are better. Soys are readily grown upon any farm and should be regularly sown where lambs are g'rown.

Early varieties of soy beans should be grown in the Northern states, threshed when ripe and the seeds kept for the lambs. The bean straw if kept dry has in it a good deal of nourishment also which the ewes will seek out and the coarser parts will serve as an excellent bedding.

There is hardly any other food that will push forward lambs like soys. They have abundant protein and a good deal of bone material also. As compared with ordinary field peas they have 29 to 40 per cent of protein, while field peas have 16 per cent and cowpeas 18 per cent. Field peas are best adapted to New England, Canada and Michigan, with some regions of high altitude in the Rocky Mountains; soy beans to all the corn-belt. As the oilmeals are steadily increasing in price with possibilities of their frequent adulteration the shepherd can not afford to overlook sources of home-grown protein.

In the Southern states the hairy vetch is a source of home-grown protein not to be overlooked. Further reference to this will be made when we take up the subject of field crops for sheep.

The lamb will drink a good deal of pure water, even while sucking his mother. It should be readily available and always clean enough for human consumption.

After the lambs are well started on feed the ewe lambs if they are designed to be kept upon the farm, and such ram lambs as may be worth 
keeping, should be separated from the others and fed differently. They may have all the oats and bran they wish and some soy beans but are the better for having very little corn. It is best if they have the run with their mothers of a field and learn early to seek part of their food outside, whereas the ones destined for market will

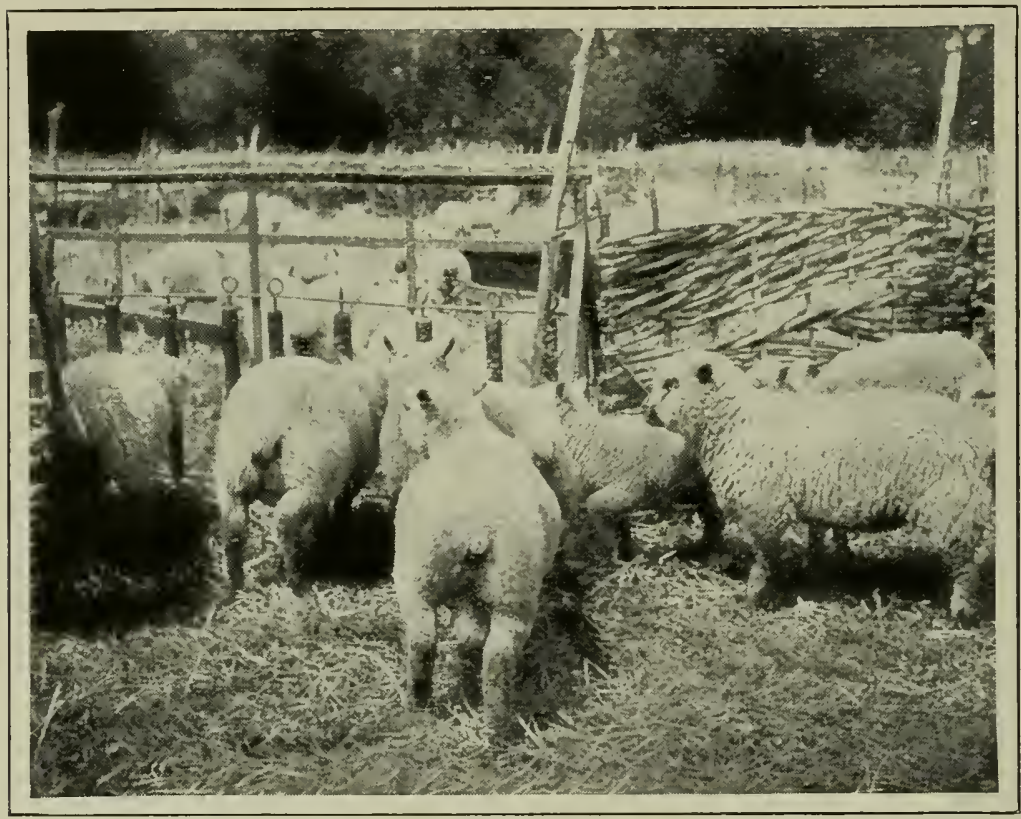

AN ENGLISH "CREEP."

grow as well and fatten quicker to have their range somewhat restricted.

The shepherd should keep close watch on the ewes, for there will come a time when they are no longer milking freely and then they will put their food on their backs. Rather than fatten them to their harm, unless they are to go to 
mirket, the grain should be gradually cut down and it will be found that the lambs at this time will take more each day.

After the fattening lambs are a few weeks old ther love to shell off corn from the ear and crack it with their own teeth. They should have opportunity to do this.

In fact, when they are six weeks old it is hardly worth while to shell or grind any more corn for them at all. They prefer it fresh shelled by their own teeth. It is folly to spend effort in doing things that the lambs delight in doing for themselves.

DRESSING LAMBS FOR FANCY WINTER MARKET.

When the lambs reach a weight of 50 to 60 lbs. or even less if they are very fat the fancy New York market will pay for them from $\$ 3$ to $\$ 12$ each if sent there by express nicely dressed and cooled. The prices depend upon how fat they are and what the season is. Big lambs, only moderately fat, sell much cheaper than small lambs that are very fat.

For this trade the lambs are dressed in a special manner as the market requires. Mr. H. P. Miller, a successful "hot house" lamb grower, gives this as his method: "It is very important to have them thoroughly bled out. To secure this $T$ have found it advantageous to hang the lamb by the hind feet in killing. Suspend a small singletree about six feet from the ground. Loop a small rope or strong twine about each hind leg and attach to the hooks of the singletree. With a sharp pointed knife 
sever the artery and vein in the neck close to the head. Be sure to sever the artery. Bright red blood is the assurance. The veinous blood is dark. Severing the head with one blow of a sharp broad axe would cause no suffering and insure thorough bleeding. I remove the head with a knife as soon as the lamb ceases struggling. Clip the wool from the brisket and along a strip four or five inches wide upwards to the udder or scrotum, also from between the hind legs as in tagging sheep. Now open the lamb from the tail to the brisket. Slit the skin up the

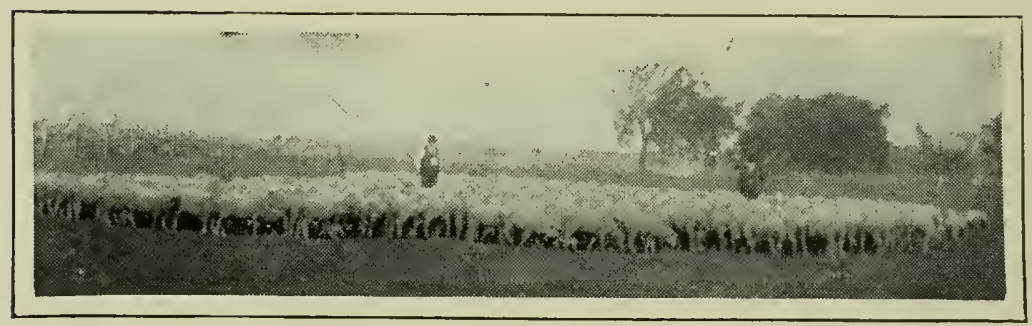

READY FOR MARKET.

inside of the hind quarter about four mehes and loosen it from the underlying muscles for two inches on either side of the openings for the attachment of caul fat. This should be re. moved from the stomachs before ther are detached, and in very cold weather placed in warm water until ready to be used. Next remove the stomach and intestines. In the early part of the season the liver, heart and lungs may be left in place but when the weather gets warm they must be removed. Carefully spread the caul fat over all the exposed flesh. Good 
large toothpicks will hold it in place. Make small slits in it over the kidneys and pull them through. This part of the work requires care and skill to make the carcass look attractive.

"Be sure that all is clean and pretty. Hang in a cool place for 12 to $2+$ hours. The carcasses should not actually freeze but come close to it. Sew a yard of clean muslin about each lamb so as to cover all exposed surface. Then line a small crate with strong paper and place three lambs in it, tacking burlap over the top. Crate them just before shipping. Ice may be put between the lambs but not in them. Prepare for market as fast as ready, three or six at a time. Aim to slaughter regularly each week, if you have lambs in condition, and keep your commission firm informed as to how many you will send."

It is worth noting that for a period of years prices for these fancy fat winter lambs have steadily advanced and the supply though increasing has not been equal to the demand. There is, however, a wide variation in prices obtained and if one finds his lambs selling at a low price he had better investigate to see what is wrong. It is better to keep the lambs to sell alive in spring than dress them and pay express charges and commission for $\$ 3$ to $\$ 4$ each in winter. During January and February, however, good lambs, such as any careful man can as easily make as any other sort, sell for from $\$ 8$ to $\$ 12$ each in New York with small prospect of oversupply for some time. 
TREATMENT OF THE LATE BORN LAMBS.

Naturally the larger part of the lambs will be born too late for the fancy trade. Nor would there be demand for all of them in the form of "fancy hot house lambs." 'There is, however, abundant profit in fattening them to be sold afoot in April, May, June or July. Usually the highest prices are obtained in June. At that time the supply of fat lambs born on the ranges the previous summer and winter-fed is about exhausted and the supply of fat native winter or spring born lambs has never yet been adequate.

To develop lambs for this live trade they should be fed just as advised for the winter lambs except that they should be permitted to take more exercise than if they are to be finished at the earliest possible moment.

When grass comes the lambs should be kept off of it until it is actually sweet. The sun must have time to get into it before it will be strong and good and to eat it before that time is a damage alike to the grass and the lambs Furthermore after they have a taste of green grass they will not eat dry forage well, so there is loss all around Keep them on dry feed therefore until there is abundant green grass and it is sweet, then you may let them go to it without fear of them shrinking.

There is little danger of scouring from eating grass after it has become sweet. The corn, of which they are now eating a great deal, has a tendency to prevent it and after a day or two 


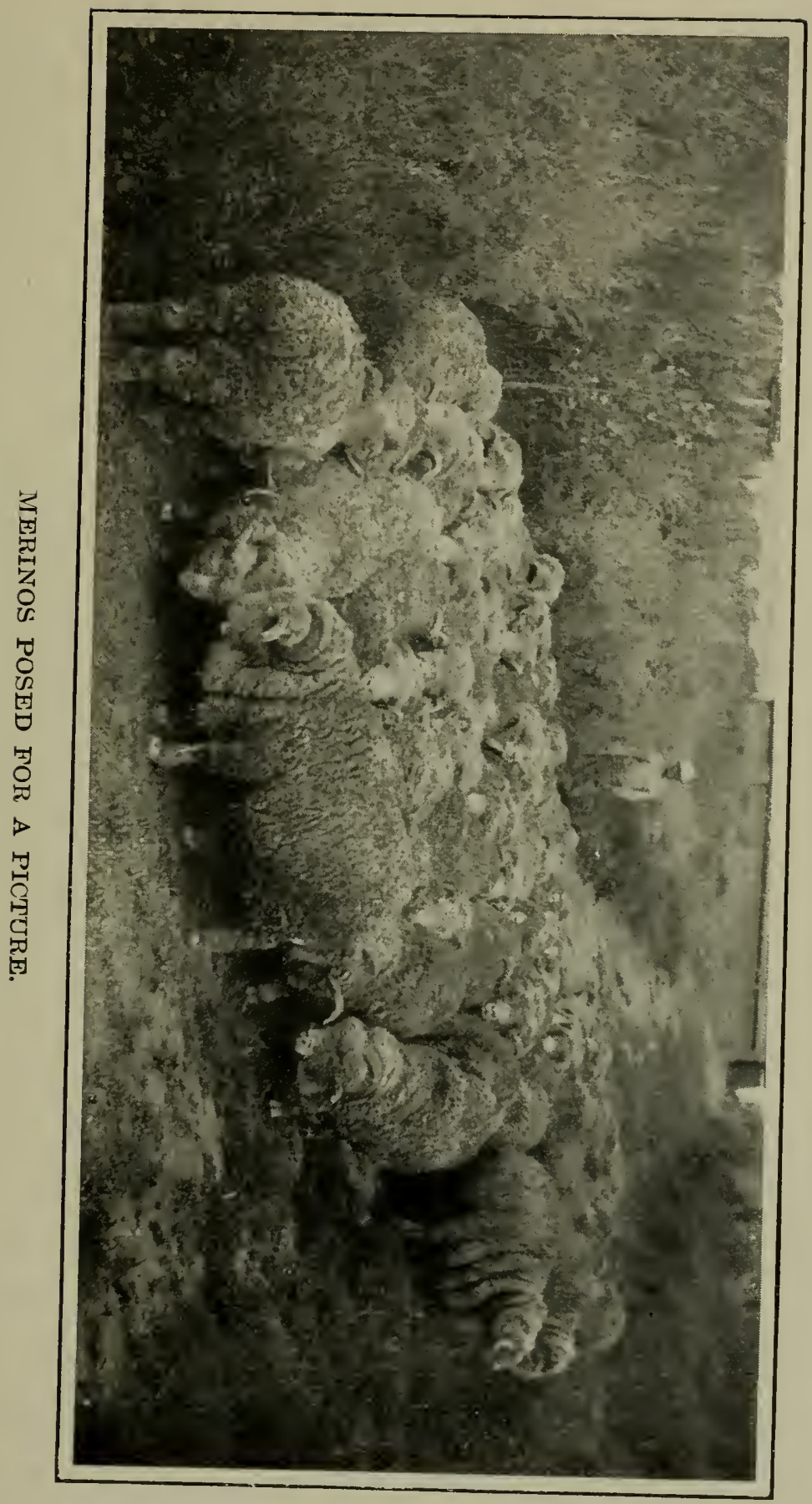



they will go on as though nothing had been changed, happy indeed beyond words in the fresh spring sunshine and fine pasture, before flies have come or summer heat to oppress.

Here is a great argument for having lambs born in winter, they may thus get such a vigorous start that when green grass comes they are able to make the most of it. There are two months in our trying climate of the corn-belt that make ideal natural conditions for making mutton cheaply; they are May and June, with sometimes a bit of April. Wherefore the shepherd should plan to have his lambs big and strong when this time comes so that they may make the most of their opportunities. There is no profit as a general thing in carrying any over through July, August and September, save those that are destined to remain permanently to replenish the breeding flock.

\section{FEEDING CORN ON GRASS.}

While in winter time on dry feed it is essential to feed bran, oilmeal or soy beans to supply the requisite protein to the growing lambs there is not so much need of supplying protein when on grass, that is, if the lambs are destined for the butcher. Green grass is more nitrogenous than dry hay and there are many clovers usually mixed in the grass so that a ration of corn (maize) alone will serve a good purpose. This may as well be fed in the ear, laring it in troughs or if there is a clean sward of thick grass the ears may simply be scattered about upon it, in a fresh spot each day. To do 
this before the lambs are weaned it is of course necessary to fence off a part of the pasture away from the ewes, allowing only the lambs to have access to it. No more corn should ever be fed at a time than the lambis will consume and that they may eat it regularly care should be taken to see that every lamb is there at feeding time. If a few troughs are set close by in which a few handfuls of oats are strewn that the ewes can get, the shepherd can readily call the whole flock up at feeding time and the lambs will rush through their creeps to get their corn while their mothers are munching the sparing allowance doled out to them.

Gains on grass when lambs have had a good start in winter are surprisingly rapid. By the first of Jume the February lambs will often weight $80 \mathrm{lbs}$. and drafts may be made and sent amay if it is convenient to market in that manner, or all may be kept till they average about 80 lbs., which will be early in June. If carefully managed there will be no culls and all will be gone and the cash in the owner's pocket before the dread of parasites comes.

Salt is an essential to the sheep and it is well to accustom them to the use of it and keep it at all times before them. It is especially useful in spring when grass comes and no doubt checks many bowel troubles when they have access to it.

SUMMER SHADE.

Shade is essential in our climate of the cornbelt. Fven in April sheep will begin to seek 
the shade during the warmer parts of the day and by May and June it is very necessary. Where the pasture is near the barn the cool, dark lower story, where were the winter quarter's, is the ideal place for the flock. It should

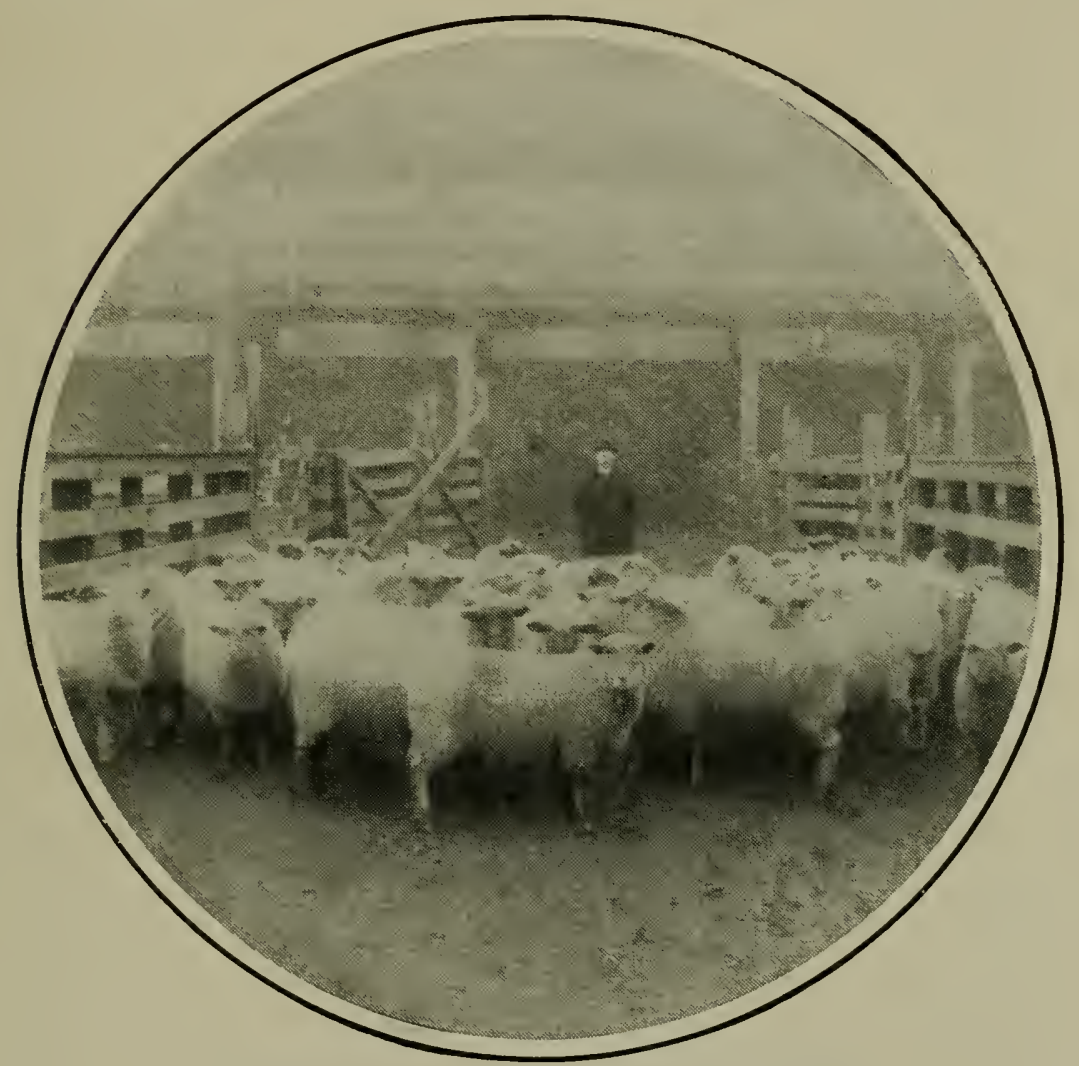

A CARLOAD OF YEARLING WETHERS.

be kept well bedded down and thus there is saved a good deal of fertility that would otherwise perhaps be heaped up in fence corners or beneath trees where it would do the pasture little good. The sheep prefer the darkness of 
the barn to the semi-shadow of trees and it is very much better and safer for them for reasons that we will presently take up under the subject of parasite infestation.

In this barn basement one should each day put down a little fresh hay and usually the flock will eat quite a bit of it. In connection with their green forage it is to them what dry bread and butter are to the boy eating green apples in summer time. It is even a good practice to salt the sheep in summer by sprinkling brine over dry hay in the barn, thus encouraging them to eat as much of it as they will. Of course there are locations where hay is hard to get and pasture is in excess There this would not be good practice, but all through the region of the corm-belt hay is abundant and really more economical to produce on high-priced land than pasture.

Corn may be fed to the lambs also in the barn basement if the flock has access to it. There is but one thing to fear; that the place may be allowed to become foul so that fleeces will be soiled and feet endangered but it is attention to these little things that assure success.

Shade in fields may be had best by movable sheds. These may be made on runners, simple roofs about 16 feet square and not high, open at the sides, made of pine boards. They need not be rain-proof since sun is what we are seeking to shelter against. A shed of this size will shelter 40 sheep and as it may be frequently moved there will be an enrichment of a good many spots during the summer. The writer 
has on the farm on which he lives a spot where his father forty years before had a temporary sheep shelter that still produces crops remarkable for their distinguishing greenness and rankness.

There are reasons why we should not permit the sheep to stand where they will, along fences and beneath trees. First the manure is wasted there; then the shade is seldom really satisfactory. Sufficient in the early morning the sun has by noon moved so that it is no longer comfortable and the silly flock will suffer much before moving away. Worst of all is the danger to the health of the sheep through parasitic infection. Lying much in one place there is an accumulation of droppings presumably bearing germs of various harmful parasites such as stomach worms, throat worms, nodular disease and the like. The droppings stimulate the growth of sweet, rich grasses here. The germs harbor on the roots and about the base of these grasses. Lambs lying in shade near by become hungry and venturing into the sun a little may nibble at these rich grasses. It is worth noting that sheep will the more greedily eat grass that grows strong, from manured land, than that which is thin and tough growing on poor soil. The lambs then nibbling this thick grass, which is thus kept short, take in many germs of stomach worms and other parasites which their mothers have deposited there with their manure. Thus disease creeps in to the flock. In England the writer has seen shepherds putting fences of hurdles about trees to prevent 
ewes lying beneath them when on grass and explaining that they found when the ewes laid in the shade of those trees they "took cold from the draughts and coughed." The facts were correctly observed but the reasoning was defective; it was not the "draught" that made the sheep cough but the throat worms and lung worms instead that gained entrance from the infected area of the tree shade.

\section{MAPKETING THE SPRING LAMB.}

Through Virginia and Kentucky there are many sheep breeders who make a practice of growing their lambs on grass alone, having them born usually in March and putting them off fat in June. They usually contract them ahead for about $\$ 6$ per cwt. They find this business very profitable and thus their rough lands devoted to sheep pastures steadily improve rather than deteriorate.

It is a temptation to the young shepherd to keep the lambs over till fall or perhaps to feed them again the following winter. This seldom pays so well as to have them fat early and get rid of them at a good price. When they come to market as late as August and from then to Christmas they must compete with lambs grown on the ranges under much more favorable conditions for cheap production. Moreover, the lambs during the hot summers of the corn-belt do not gain much fat; if in fact they hold what they made in May and June they do well and there is besides that terrible danger,the parasite. 


\section{DOCKING.}

Unless one is certain that his lambs will go early to market, say at an age not exceeding three months, he had better dock and castrate them. Tails are unnecessary appendages to a modern sheep and are apt to become fouled. A docked lamb has a squarer look and seems fatter than one with a tail. What blood goes to nourish a useless tail would add to the growth of the rest of the body no doubt. Docking may be done at a very early age, within ten days after birth if the lamb is strong, and there is then slight shock. Tails may be severed with one stroke of a sharp knife, (cutting from the under side) or by use of a mallet and chisel, but a better and safer way when purebred and well fed lambs are docked is by use of hot docking pincher's. These are readily made by the country blacksmith. They are shaped like large shoeing pinchers only much heavier and with a wider opening to admit any tail, for sometimes one will wish to dock a mature sheep or cut off a scrotum from an old ram. They should be thin at the edge but not very sharp and thick back of it to hold the heat. The manner of operation is to have a board with a hole bored through it of a proper size to admit the tail of the lamb. This board protects the adjacent parts against the heat of the pinchers. They are heated to redness and quickly sever the tail which will not bleed a drop. Some disinfectant is then applied and the lamb let go. After flies come one must watch that the stumps 
do not become infested with maggots; there is no other danger. Pure-bred and well fed lambs will sometimes bleed to death when their tails are cut with knife or chisel. When no docking pinchers are at hand the stumps may be corded for a few hours.

\section{CASTPATION OF OLD RAMS.}

These docking pincher's are convenient things to have for castration of old rams, or of any sheep past the age of lambhood. The method is to lay the ram on his back; one man seizes the scrotum and testicles and pulls them out from the body and another simply sever's them all together with the docking pinchers used very hot.

There is no bleeding, though the operation should not be too hastily performed, as there is need of a moment's contact with the hot iron to sear the arteries. The application of disinfectants completes the operation. A thin board may keep the heat from scorching the body. The writer has thus operated on a sixyear-old ram and had him get up and go to eating hay quite unconcerned. It is probable that the hot iron destroys the sensibility to pain to quite an extent.

\section{CASTRATION OF LAMBS.}

Castration of young lambs is a very simple process. The lambs should be two weeks old and strong. The end of the scrotum is cut off, the testicles made to emerge and are then pulled out with the adhering cords. Some shep- 
herds practice seizing them with their teeth; this is a common practice on many Western ranches. It is not usually necessary to apply anything in case of these young lambs but a mixture of lard and turpentine, or tallow and turpentine : combined in proportion so as to be soft will deter germs and make healing more rapid. There should not be a loss from docking and castration of more than one lamb in 500 and it is a satisfaction to have both done so that whatever age the lambs may reach they will not in marketing suffer a "dock" because of their "bucky" condition.

\section{WEANING.}

As a rule it is not necessary to wean lambs before they go to market. If they are fed right they will while sucking their mothers reach a weight of 75 to $85 \mathrm{lbs}$. if of mutton breeds. 'There is nothing better than mothers' milk except more mothers' milk! Lambs that are to remain on the farm, however, should be separated from the ewes when ten or twelve weeks old, or when the advent of warm weather makes parasitic infection a danger. An exception may be made of the ewe lambs, which may in some cases run with their mothers until they are weaned naturally. The advantage of weaning is that it makes possible the separation of the young and old and thus the young things are put by themselves on clean pasture where there can be no contaminated grass and thus they escape infection and parasitic diseases. The proper way to wean lambs is by taking away 
the ewes, leaving the lambs in the pasture where they are accustomed to run. Build in the pasture a small yard or corral having creeps through which the lambs can run; the ewes, after being away from the lambs for 12 hours, are returned and yarded there when the lambs will run in and milk them out, and when they have again gone out to feed the ewes may be taken away for another period. Thus there is a gradual separation, neither ewes nor lambs experiencing a shock, and if the ewes are put on rather sparce picking they will soon be dry. There is but one danger, viz.; there may be some ewes yet milking so heavily that their lambs will suffer from gorging upon their return. The watchful shepherd will be aware of such a case and catching her will milk her out somewhat before letting the lamb at her, or if it be a lateborn lamb allowing it to run with her a little longer. 


\section{CHAPTER VI.}

\section{SUMMER CARE AND MANAGEMENT.}

THE EWE FLOCK.

In winter the shepherd is a god to his flock. Shut away from natural sources of food supply the sheep depend entirely upon his providence and therefore their thrift rests entirely upon his knowledge and willingness to give. In summer Nature provides forage in abundance and turned out in the fields the sheep can choose as their instincts prompt them. They should then thrive upon pasture as nowhere else. They would were it not for two things: one that the shepherd too often considers a "pasture" as being an enclosure surrounded by a good fence, regardless of what the forage may be within; the other that in summer time come pests of flies, maggots and worms, internal parasites. The shepherd who thoroughly learns the lesson of prevention of these pests will find his work a joy and will stay with it and make a large profit from his flock. The man who simply turns the flock to pasture and gives it no more attention or thought will very likely find himself confronted with a lot of diseased and 
unprofitable sheep within a few years and his farm perhaps so infected with germs of parasites that there is no longer any profit in keeping sheep there.

Most of the trouble comes from the internal parasites, and while there is a long list of them that afflict sheep nearly all the trouble in our country comes from two or three species. By far the most prevalent and troublesome is the twisted stomach worm (naemonchus contortus). This inhabits the fourth stomach of the ewe and she carries it through the winter even though she may seem to be in good health. In spring and during summer the worms become filled with eggs, "ripen"' and pass away. Just how the young germs then re-enter the sheep or find a home in the more tender stomachs of the young lambs no one knows. They probably hatch in shallow pools of stagnant water (infections in Texas and New Mexico are thought to be by this means) or they attach themselves to the moist grass close to the ground and are taken in from that position. It is noticed that old and rich sheep pastures covered with short, sweet grass are frequently the most fatal to young lambs even when there is no stagnant water in them.

It is not too much to say that the stomach worm has done more to discourage sheep husbandry in the corn-belt of America than all other canses put together and many a man has gone out of business from the depredations of this little enemy who did not even know that such a pest existed. 


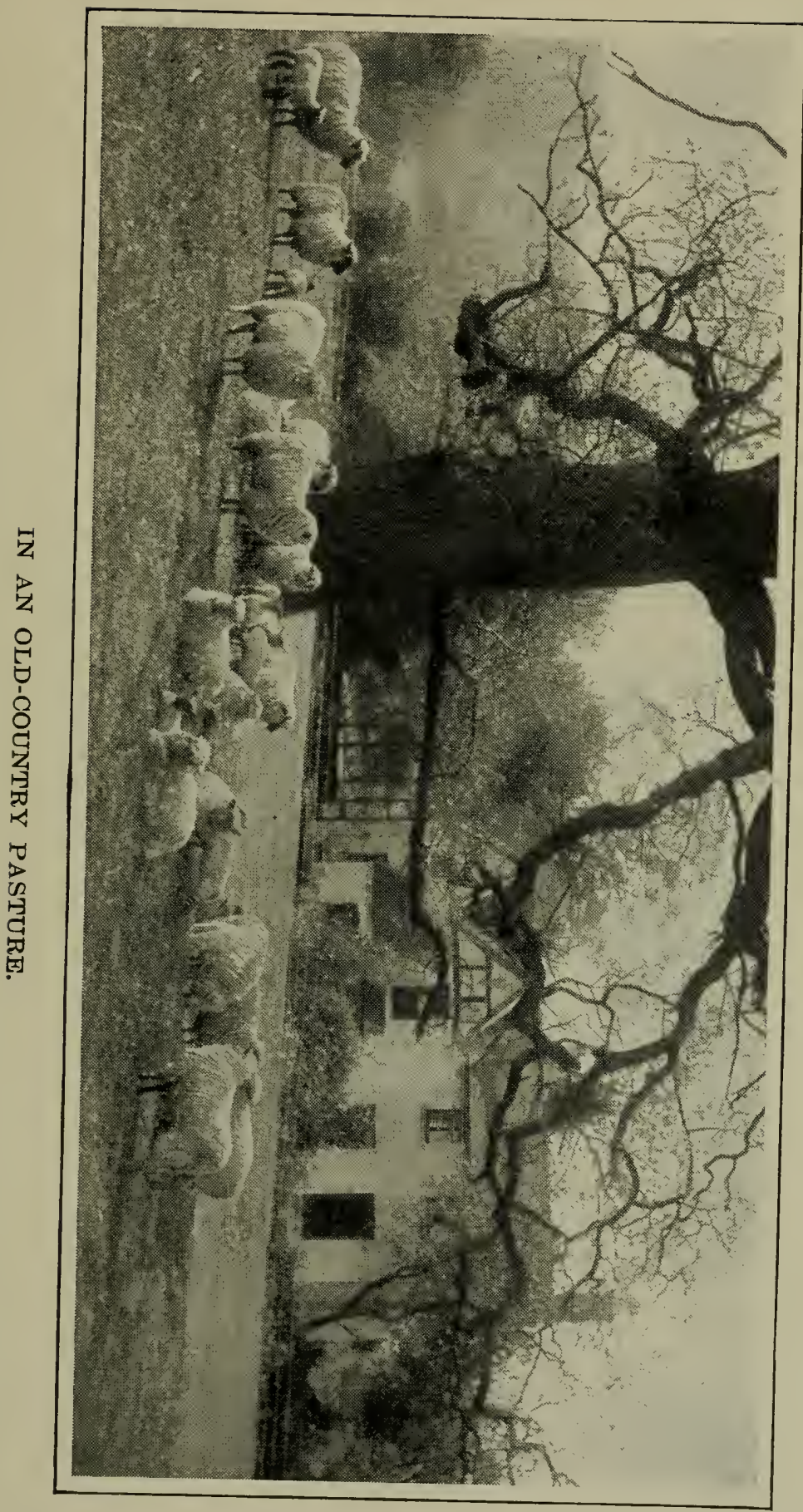



The symptoms of infection from stomach worms are first; the wool appears lusterless and if pressed with the hand does not spring out again as when the animal is in vigorous health. Looking more closely, the red in the veins in and about the eye seems pale and when you part the wool the skin has lost its pinkness and if the disease has progressed far it looks white and chalky. There is a disordered digestion and perhaps a depraved appetite, the animal may gnaw earth, rotten wool or bark, there may be diarrhea or constipation. Before death comes there will probably be "black scours." Old sheep seldom die from stomach worms but are run down in vitality by the pest while lambs may die in great numbers.

Stomach worms seldom ever trouble sheep in cool regions and there is some evidence that a temperature of 50 degrees in the soil prevents their development. Therefore they do not spread through the flock until warm weather, which may come in May and certainly comes in June. Up to that time the lamb crop is comparatively safe to run with the mothers; after that the idea of the twisted stomach worm must be kept ever in mind.

It may be well here to call attention to the fact that there are considerable regions in America where fear of the stomach worm is not felt. In Massachusetts, Maine, New Hampshire and Vermont there is little or no evidence of Hrmonchus infestation. Northern New York and the mountain regions of that section should be almost exempt from danger if flocks 
are properly mauaged. Ontario in Canada, seems to be without the dread pest. The writer has seen wonderful flocks in Vermont and Ontario managed very simply on thick, sweet blue-grass and white clover pastures and without a trace of this malady. The road-side sheep of Ontario graze peremnially on the same restricted areas and escape infection. So in northern Michigan, in the Upper Peninsula especially, is a grand field for easy and almost care-free shepherding. Northern Minnesota and Tisconsin should prove little subject to this pest.

One evidence that cool climates deter the development of the Hæmonchus contortus is seen in northern England and in Scotland. On the Cheriot hills flocks grow as thick as the grass will bear and for many centuries this has been so. In Scotland the same is true and the writer in a rather careful study of conditions there saw no evidences whatever of infestation of this pest. There is some parasitism in that region but it is more likely to be of taperrorms or the brain parasite that causes "gid" or" "stag'ger's.",

It is a matter of wonder to the writer that more men do not in New England and our other northern border states turn their attention to sheep growing on a scale large enough to make it a business. There should be whole regions given up to the breeding of sheep and such breeds as the Cheriot. Lincoln or Cotswold would there find a congenial home, while Shropshires and Southdowns would thrive well 
and furnish the market with prime mutton. Shepherding without the fear of stomach worm infestation is a delightful occupation.

The simplest method of keeping the lambs in health in the summer time is to separate them from the ewes and put them on grazing that has had no sheep on it for a year, or at least that has had no sheep since the previous

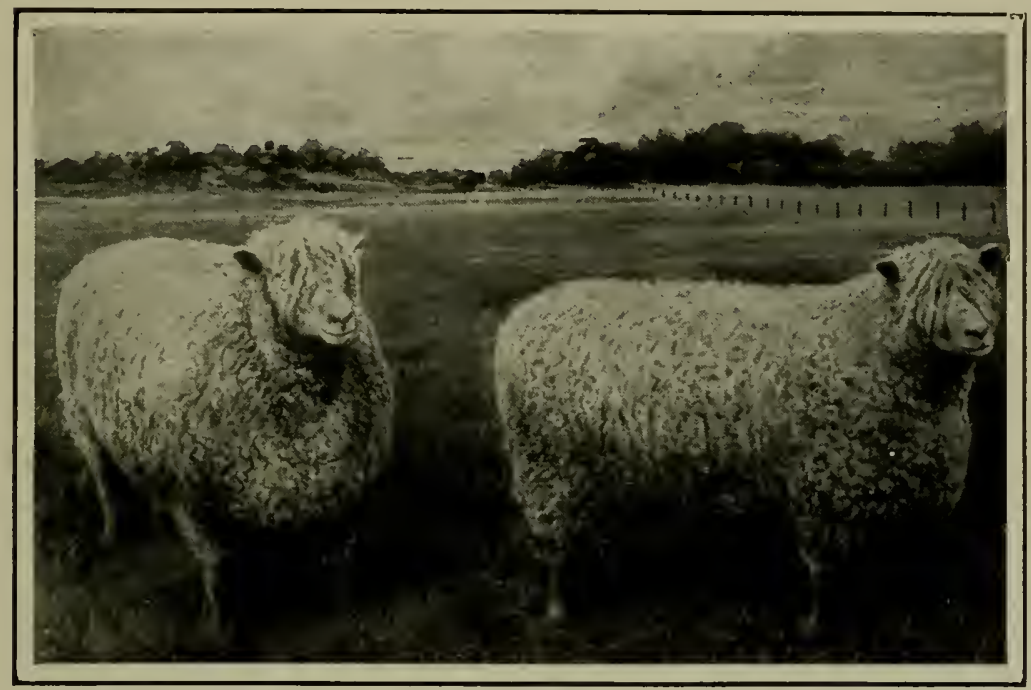

COTSWOLD EWES.

fall. We will take up the care of the lambs a little later.

The ewe flock is easily kept in health. Mature sheep are resistent to parasites unless they are depleted in vitality by reason of being bred too young, or by suckling their lambs when poorly nourished. It is only necessary to give them sound grass and as good a variety of herbage as is at hand and to change them from 
one pasture to another about once in ten days or a fortnight. 'The old adage, "change of pasture makes fat sheep,', is true and it depends upon two reasons: change gives chance for fresh herbage to spring up and it gives parasitic germs chance to die before finding again a living place in the body of its former host. It is better then to divide large sheep pastures into several divisions and during warm weather, say about the middle of May till the middle of September, to change the flock from one division to another letting cattle or horses follow them, or letting the pastures have rest till the flock comes back again.

It would not help matters any to keep sheep in each division and change by transposition, a common and sinful practice, as one lot would readily infect the other. It is not good management therefore fully to stock a pasture with sheep in any part of the United States east of a line running about with the 100th meridian, or roughly along the western limit of the corn-belt. The exception to this rule would be in the case of high mountain pastures or in the far north, where the air and soil are cool enough to deter the spread of parasites.

'These stomach worms are not very hard to destroy or drive out of the body of the sheep. The witer introduced the gasoline treatment into the United States and it has given excellent results in his practice. Coal tar creosote is said to be as good and perhaps better. Some coal tar dips are used successfully in destroying the stomach worm. We will give explicit 
directions for administering these remedies further on.

\section{A SYSTEM OF MANAGEMENT THAT INSURES A HEALTHY FLOCK.}

Two men in America fought stomach worms all through the disastrous year's of the $90 \mathrm{~s}$, when little was known to help; they found light, they conquered the pests in a measure, and kept on keeping sheep and studying flock management. Finally each made a journey to England and studied the conditions there with a view to solving the problem for America. There they found hurdling the best answer to the question. Independently of each other they reached the same conclusions as to the practical solution of the question in America. Dr. H. B. Arbuckle of West Virginia and the writer were the two men. But they wish to give all due credit to the Department of Zoology of the $\mathrm{Bu}$ reau of Animal Industry at Washington for at last giving accurate details of the life history of the Hrmonchus contortus (formerly called Strongylus contortus) for without the details that we now have no certain plan could have been formulated.

The basis of this plan is the fact that lambs are born free from parasitic infection; they are healthy. It is only necessary to keep them healthy by preventing infection. Their mothers carry over in their bodies the germs that will infect them in the form of mature stomach worms, which when ripe pass away in the droppings and thus infect the pasture. When the 
temperature is below $40^{\circ}$ the eggs will not hatch. When it is above that they will hatch out in a few hour's or in a week or so, depending upon how warm it is. Freezing or drying soon kills the unhatched eggs. So it is seen that ewes will not pollute a field in Winter, their droppings are sure to be soon frozen, at least in the region where sheep are mostly kept. But if the tiny worm hatches from the egg it feeds for a time upon the material of the manure and continues to grow till it is about one-thirtieth of an inch long. Then it creeps up on a blade of grass and waits to be swallowed by some lamb, after that it finishes its growth within the fourth stomach of the lamb, and, incidentally, finishes the lamb as well.

Under the heading of "Diseases of Sheep" will be found entire the very interesting bulletin of Dr. B. H. Ransom on this subject.

Now how to manage a flock with safety and profit on natural grass. To begin with the ewe flock should be treated for stomach worms. This is best done in the fall, when they come from pasture. It may be again done in the spring before their lambs come. Remedies for treatment will be found under the heading "Diseases of Sheep." The writer is of the opinion that use of some of the coal-tar dips, in small doses, much diluted, will eventually be recognized as most efficient. This treatment alone has doubled the weight of lambs in some experiments in Kentucky. Next, the flock shouid at the approach of spring weather be confined to the yard and shed. There 


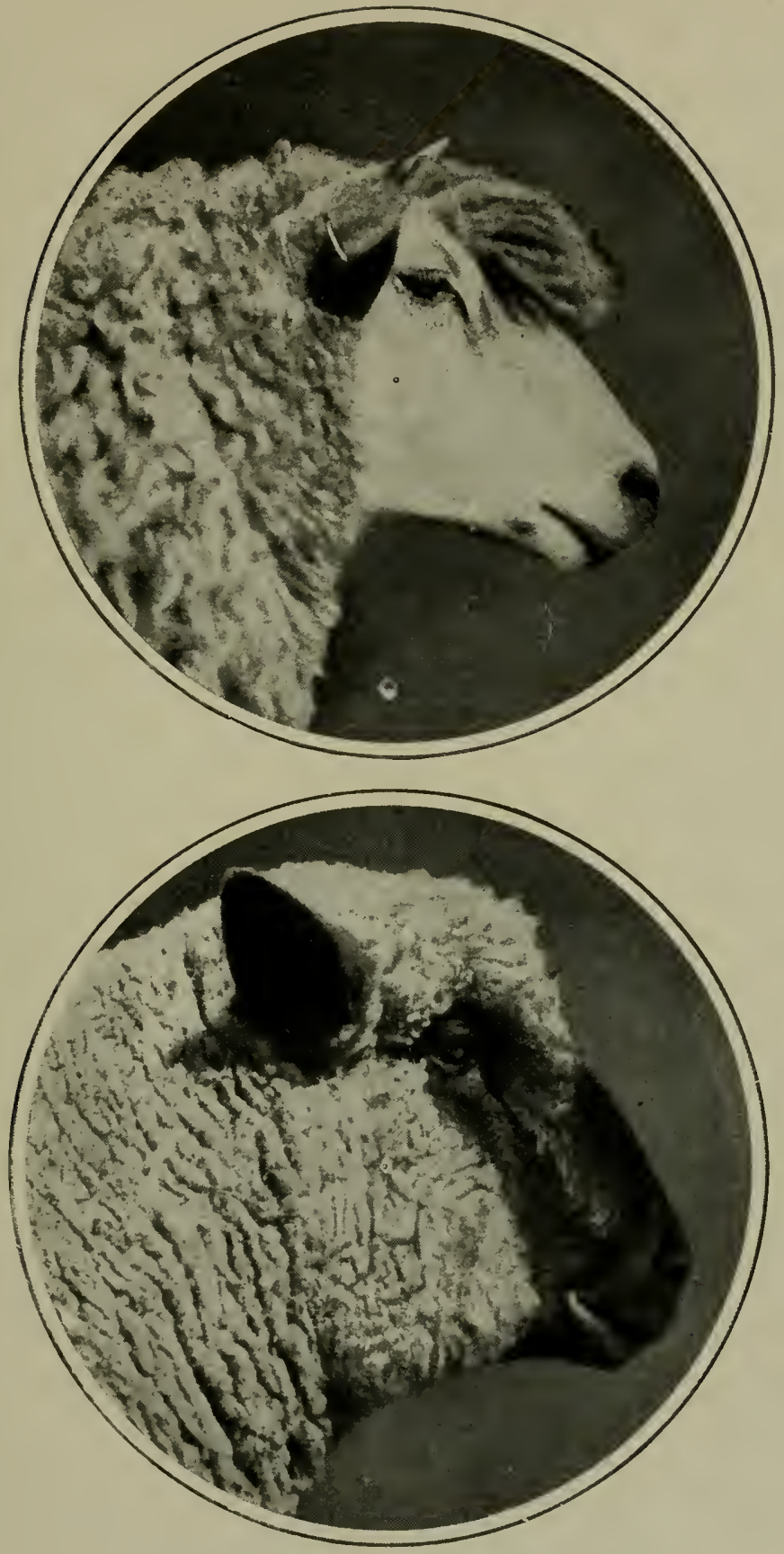

STUDIFS IN SHEEP CHARACTER. 

are two reasons for this; the one that it is better for the grass, and thus in the long run better for the flock, and the other that there is thus no contamination of land over which the lambs will later feed. If it were possible to wholly eradicate the worms from the ewes by treatment this care would not be needed, but unfortunately it seems almost impossible with our present knowledge to kill all of the worms by any medication. While confined to the yard the lambs will probably be born. It is essential that the flock be well fed at this time so that the ewes be full of milk. If desired there may be provided a r'un to a rye field, or to some grass pasture that will not be afterwards used that summer, to help stimulate the milk flow. By May 15 probably the grass will be so forward that the flock may be turned out for good. Now begins the new management. Instead of turning the flock to a large pasture to roam over it at will turn them on a very small part of it. How best to manage this will depend upon circumstances. The writer thinks that in our land of small supply of labor and much hurry and turmoil during the summer season it is safest to divide the pastures by permanent wire fences. These are not costly and need not be very high. We will, then, turn the whole flock together into the fir'st division; none shall be scattered about. Of course there may be two flocks, one with lambs and a dry flock, but the dry flock had better be put apart somewhere or else put with the ewes. It will not do to let anything interfere with the regular rotation of 
these pastures. Now once in this pasture the flock will be allowed to eat it down close to the ground That will not hurt the grass, for all will go on in a short time and the grass may spring up again. This is how pastures are often managed in England by hurdles.

Doctor Ransom says that sheep may probably be safely left on May pasture for two weeks. Tre will shorten this time to 10 days, to make sure. That is, the germs falling to the earth could not before 10 days find their way back into any sheep or lamb, and we are going to move the flock on before they are able to get in.

Now in the division between this pasture and the next we will place creeps so fixed that the lambs can readily pass through to the next enclosure. This they will early learn to do, and so they will be eating the fresher parts of the herbage in advance of the ewes.

In ten days then the whole flock will go forward one pasture, the lambs yet having access to the fresher feeding on ahead. Doctor Ransom says we will need for this sure treatment the following divisions:

For May, 2 pastures.

For June, 4 pastures.

For July, 4 pastures.

For August, 4 pastures.

For September, 3 pastures.

For October, 2 pastures.

That makes 19 enclosures in all and insures that the flock shall be kept in absolute freedom from infection throughout the year.

However, one will not absolutely need so 
many enclosures as that. By June many of the lambs will be ripe, by July many of the others, and even when the lambs are born late when managed in this way they should all be ripe as peaches by the middle of August. After the lambs are gone the ewes can be managed a little less carefully, especially if they are in strong condition, though there is a comfort in knowing that every stomach worm germ that falls to the earth must die from lack of a host.

To make this thing doubly successful put flat bottomed troughs in the pastures ahead, where the lambs run, and put feed in them; any sort of grain, corn, oats, barley, bran, coarse-ground or broken cake or oil meal. Thus the lambs will grow like weeds and pay many times over for their grain. Thus more sheep may be carried on the same ground than would be possible under ordinary treatment. There is scarcely any limit to the number of sheep that can be safely kept on an eastern farm under this system of management. The limit is, of course, the size of the farm and the amount of grass. Even this can be greatly helped by soiling. Racks may with great profit be placed in the fields and the ewes fed green crops, fresh mown oats, peas, clover or alfalfa. Thus twice as many ewes may be kept as the grass alone will support. The writer would suggest that about 400 ewes would keep one man nicely busy in caring for them and their lambs, hauling water to them, soiling somewhat, and feeding the lambs. He would not hesitate to undertake the management of 400 ewes on one farm 
in any part of the corn belt, the regions most infested with stomach worms. There is no business more sure of profit than this. Lambs sell remarkably well and the prospect is that as the western ranges are diminished that they will sell better for the ravages of the stomach worm deter eastern farmer's from going into the business. The two serious obstacles to be overcome are; first, the question of water and next, the question of shade. Water is readily hauled in mounted tanks as it usually is in Fingland. Shade is not absolutely essential. The writer has seen very fat sheep in the San Joaquin valley of California confined to the alfalfa meadows and with no shade whatever. Probably a system of canvas sheds, long and narrow, would not be very expensive nor too troublesome for one man to move and set up unaided. Any sort of good grass will serve. Kentucky blue grass is to be preferred, perhaps brome grass (Bromus inermis) is better, clovers may be utilized and oats sown to be grazed off, with peas.

The writer does not hesitate to say that he looks forward to seeing many sheep farms established in the cornbelt each carrying from 200 to 500 ewes and managed nearly under this system. He feels confident that no other branch of the live stock industry holds forth better prospects.

It should be borne in mind that the earlier the lambs are born the sooner they will be gone to market, and thus the fewer pastures will be needed. Also the market is usually best in 
Jume and July, after the flood of fed lambs has passed and before the new crop from the ranges has started to come.

Besides the stomach worm there is the worm that makes the nodular disease of the intestines. Any observant man who has dissected a mature sheep has often noticed on the small intestines little nodules or " knots." These are really small tumors, filled with a greenish, cheesy substance. They do not do much harm when they are few in number but the trouble is a cumulative one and the number's of the nodules increase until after a time digestion and absorption are much interfered with. Sometimes parts of the intestines becomes calcified, that is, so impregnated with lime salts that they are almost like stone. Death ensues in a longer or shorter time from the nodular disease. It does not work quickly as does the disease caused by the stomach worm. The worm causing these tumors is called osophagostoma columbianum.

This nodular disease is a hard one to cure, if indeed it is possible to cure it at all after it is established. Prevention is about all that we can do. Dr. W. H. Dalrymple of the Louisiana Experiment Station has shown, however, that it is readily communicable from affected ewes to their lambs through the medium of the pasture. He has also demonstrated that where diseased erres are kept.confined to the barn and their lambs allowed to run on clean pasture not contaminated by the presence of any old sheep, the lambs remain healthy and thus a new and healthful stock can be had even from a dis- 
eased flock. None of these diseases originates spontaneously. There are no other known hosts of these diseases than sheep, goats and perhaps deer, so it is merely a question of starting with the lambs, born free of all parasites, and lieeping them in health by putting them on fresh and uninfected pasture.

\section{USE OF SOWN PASTURES.}

The easy way of management is to use only the wild or natural grass pastures, the same ones year after year, but there is often great good resultant from sowing special pasture crops for the flock. Rye sown in the fall will afford very useful pasture before Christmas and again very early in spring. If vetches are sown with the rye in mild latitudes they will together in spring make good grazing, and clover sown in March will take the land after the rye is gone. Rye is not a rich grazing crop; in fact, is a poor one, but it adds the element of succulence to the diet and thus has its value. Then it gives employment and exercise in the way that the ewe likes best to take it, wandering about the field and picking here and there. Then there is almost no danger at all of parasite infection from grazing rye, or from grazing any sown crop for that matter. Rye where clover is sown with it should not be too closely grazed after the clover gets started and it is well to cut it for hay before it heads. If permitted to head it becomes woody and makes 


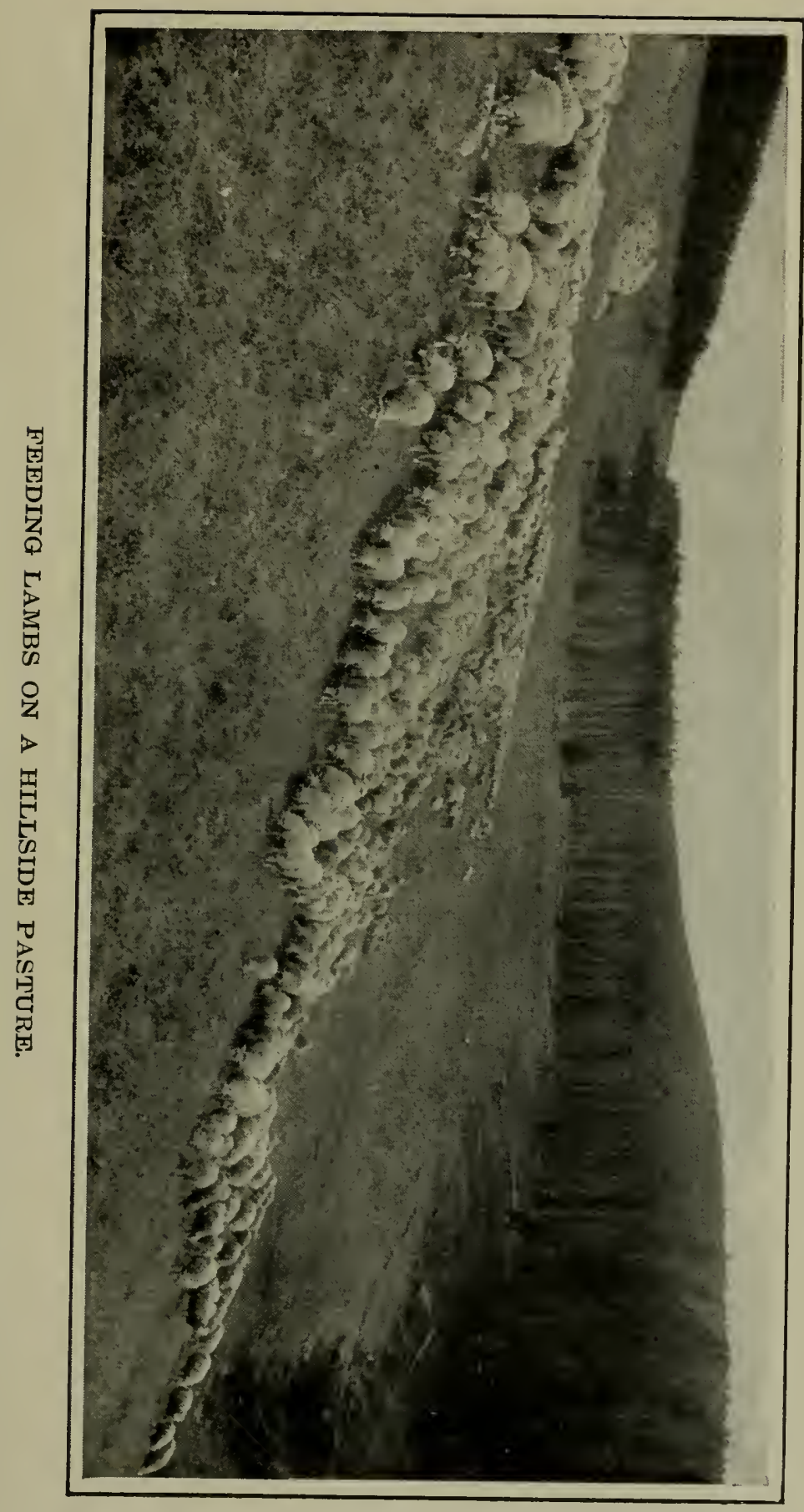



very inferior hay, and the clover does not come on again so quickly.

OATS AND ALFALFA PASTURE.

Oats sown early in spring with clover or alfalfa form an excellent pasture for about two months in late spring and early summer, following the use of rye. Oats should be sown on good soil or should be well fertilized and may be sown rather thickly, as much as two bushels per acre, with about a peck of clover or alfalfa. It the land is well drained, a clay loam with limestone in it, alfalfa will make the best growth and pasture. Red clover however, thrives on thimner soils than alfalfa and is the pioneer among the legumes. On any rich limestone clay soils, however, alfalfa is the queen of forage crops from Labrador to the Gulf. In depasturing oats where legumes have been sown with them some judgment must be exercised else the delicate clover's will suffer. It is well to allow the oats to get up about eight inches high, then turn in and permit the sheep to eat them down pretty close, which should be done in three or four days. If there are not enough sheep to do that, divide the field by temporary fences or hurdles, depasturing a part at a time.

As soon as the oats are eaten down take the sheep off and let the plants come again. They may thus he repeatedly grazed and the result will be a beautiful stand of clover or alfalfa.

After midsummer, however, it may be wise to keep the flock entirely off this field, letting 
the clover or alfalfa get strong to withstand the trial of the coming winter.

Young clover and alfalfa should never be grazed hard nor be eaten close the first year else the stand will be seriously weakened.

\section{CLOVER AND ALFALFA PASTURE.}

By all odds the most useful summer pastures in the cornbelt are those composed of clover or alfalfa. There are several distinguishing advantages in these crops: they renew the soil, they are rich in protein and add to the size, health and vigor of the sheep; they afford a great amount of grazing and they are almost absolutely free from danger of carrying parasitic infection. The reason of this healthfulness of these plants is that sheep crop the higher leaves and stems, leaving the parts close to the ground and thus escape germs that may lurk down close to the earth.

Either red clover or alfalfa is too richly a nitrogenous product, however, to be grazed alone. Sheep confined to either of them must eat too much protein and therefore will crave food of more carbonaceous or starchy composition. They will greedily eat grasses or even hay or dry straw to help balance their ration. Therefore it is wise to sow a mixture of grasses with the clovers. The best grasses for this purpose are smooth brome grass and orchard grass. Either of these come on quickly and give a continuous grazing with the clovers. Of the two, brome grass (Bromus inermis) is by far the better, yielding more grazing and be- 
ing better relished by the stock. Indeed this brome grass is one of the best pasture grasses we have and of easy culture, though it should always be sown in connection with some clover, else it fails to yield as it should.

Red clover and alfalfa should not be mixed together. If they are the red clover having the habit of more vigorous growth at first crowds badly its slower neighbor. It is wise, however, to put about 10 per cent of alfalfa seed in all clover mixtures sown on suspected alfalfa soil, for the small amount of alfalfa will infect the field with the alfalfa bacteria so that in after years it may be all profitably sown to alfalfa alone.

DANGER FROM CLOVER AND ALFALFA PASTURE.

Sheep grazing leguminous crops often suffer from hoven, or bloat, caused by the fermentation of the tender leaves within the paunch. The greatest danger of this is when the clover is young and tender and growing rapidly.

After alfalfa becomes woody there is not much danger from bloating. Nor is there so much danger when grasses are mixed with the clovers in the pasture. After sheep become accustomed to eating the clovers, they have then learned somewhat by instinct how much to store within. Pasturing on clovers is never absolutely safe, yet certain simple rules will almost always prevent trouble.

First, the clovers should have reached neariy to the blossoming stage before the sheep are turned in. 
The sheep should not be hungry. They should have a preliminary course of feeding of some sort till their appetites are well sated. Perhaps a fill-up on good grass pasture will generally best accomplish this.

They should go on the clover or alfalfa pasture after eating all they will of other things at about ten o'clock in the morning, at a time when ther naturally prefer to cease eating and go to lie in the shade.

They should be given salt as soon as put upon pasture, and salt mixed with air-slaked lime should be kept before them.

They should never thereafter be removed night or day, rain or shine, as long as they are desired to graze the field.

Of course they may have the run of an adjacent grass pasture, and be permitted to go and come at will, but they must never be taken away even for a few hours and allowed to get hungry and then returned to the clover or alfalfa field. If they are, there is danger that they will gorge themselves too suddenly and bloating may result.

The writer devotes considerable space to the subject because he has had a long and successful experience in pasturing clover and especially alfalfa with sheep, and in his practice he has found these rules essential to success. It is well worth the risk, seeing that this pasture returns such well nourished and healthy sheep and is so free from danger of parasitic infection. The writer has annually lost from 2 to 4 per cent from bloat on alfaifa pasture, com- 
monly of animals not in the best health, and if it has returned the other 96 or 98 per cent in fine health to him, he considers the sacrifice of small amount.

The following remedies for a bloated sheep are good:

When first in distress, administer three tablespoonfuls of raw linseed oil in which is a teaspoonful of turpentine.

If this does not relieve at once, tie or hold a large corn cob or stick of similar size crossways in the mouth like a bridle bit; hold the head up, stand astride the ewe and seek gently to press out the gas with the knee. Do not use too much force.

Pour several buckets of very cold water slowly on the distended side over the paunch. This often of itself relieves the distress by stopping the accumulation of gas.

If there is too much distension for these measures to relieve, make an incision on the left side, high up, where the greatest distension is seen, and let the gas escape. A trochar is best for this but a penknife will serve. The incision should be just large enough to insert some small tube-a small joint of cane fishing pole, a pipe stem or goose quill.

Keep hold of the tube, else it will slip within the paunch and be lost and perhaps do serious damage to the sheep. After relief has been had disinfect the wound. It should not be large enough to need stitches but care must be had that flies do not blow it. Pine tar will re- 
pel flies. The wool should be cut away from the wound.

There will be some years when there will not be occasion for any remedy whatever and with the same treatment there will be at other times more or less trouble. Inuring hot and wet

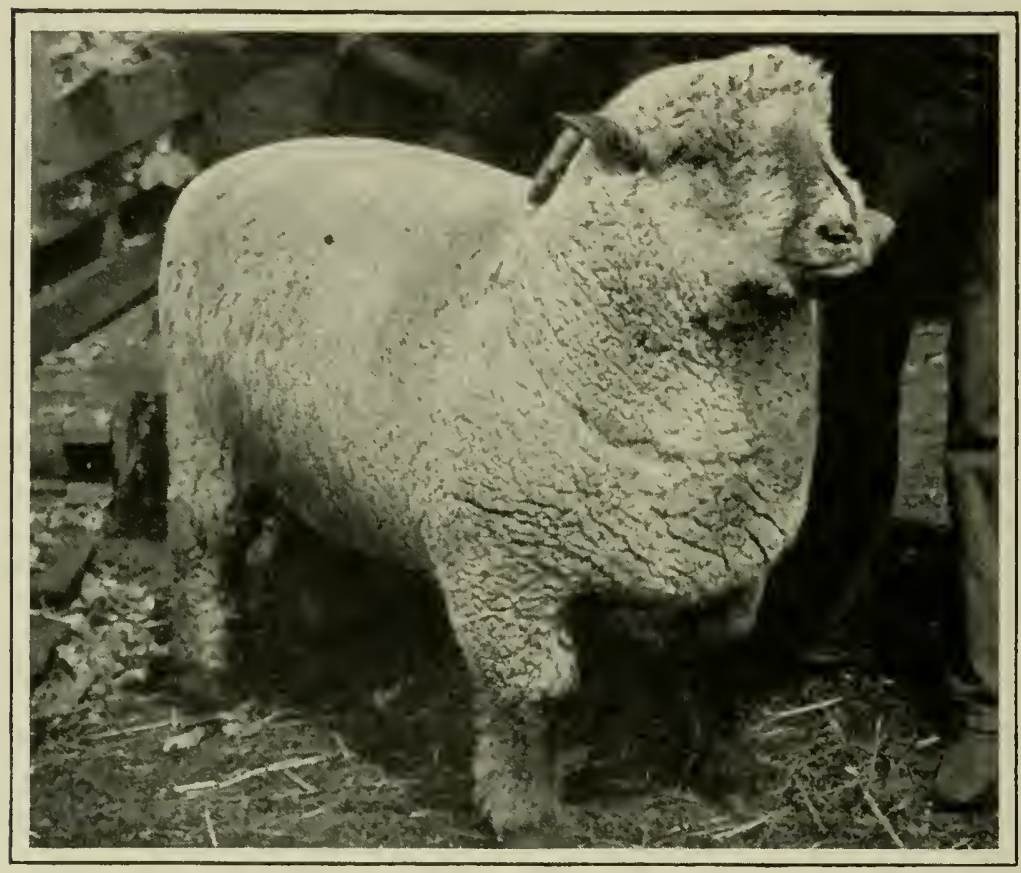

YEARLING OXFORD RAM.

weather when alfalfa is stimulated to very rapid growth more trouble may be expected.

'The writer has been in the habit of pasturing alfalfa and ret allowing the sheep to shade in the barn, permitting them to come off in the morning when it gets too hot for their comfort. He has, however, been careful that a boy should 
stir them out and send them fieldward again by three or four o'clock in the afternoon.

In sowing alfalfa that probably may be pastured, be sure to sow a mixture of brome grass (Bromus inermis) with it. A light scattering of brome seed is best, else it will soon crowd out

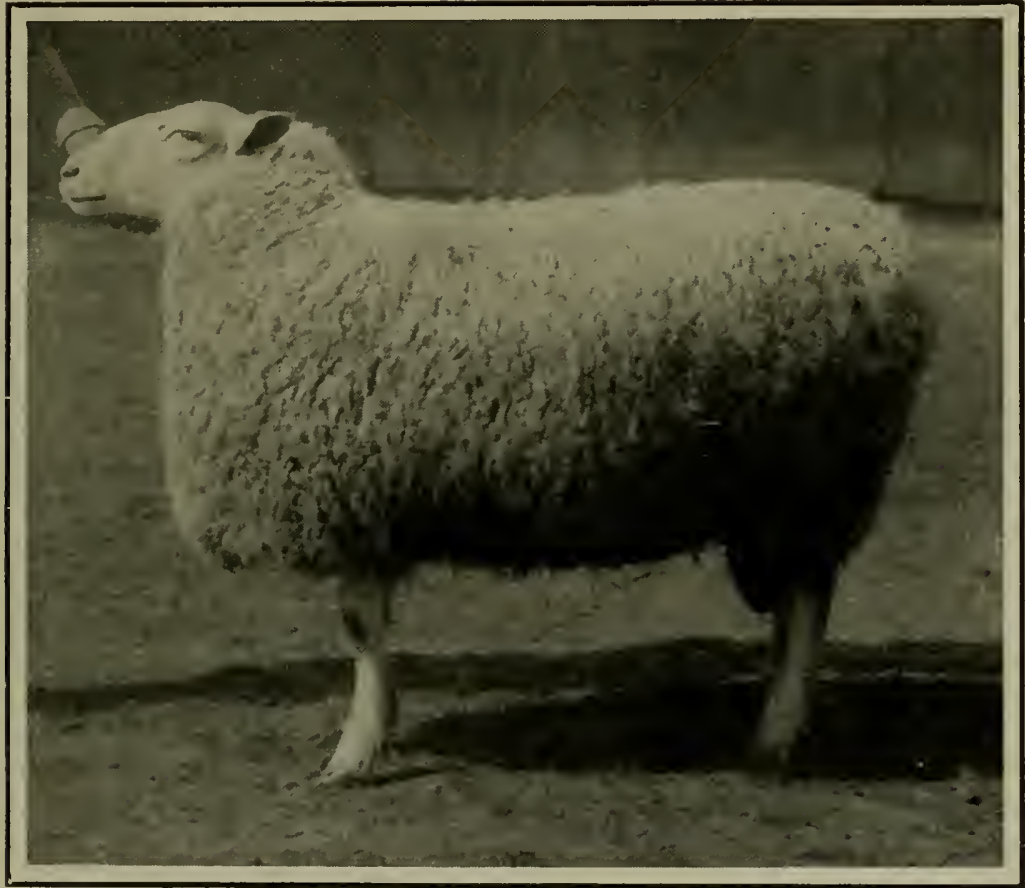

LEICESTER RAM.

the alfalfa. We have had no difficulty in eradicating the brome grass when afterward the fields have been cultivated.

The writer has solved most of the problems of summer management in the way outlined. One serious trouble, however, remains for solu- 
tion. The ewes will often get too fat under such treatment and sometimes refuse to breed regularly. He has not yet found a solution of this problem. In England, where this often occurs, the fat ewes would go for mutton and there would end that difficulty, but where one has a flock of pure-bred sheep of considerable value this is not a satisfactory solution for America.

Some manner of exercising the flock will probably prove the best cure for the sterility but as a business proposition with a grade flock it is no very serious matter.

Where one is within reach of tracts of rough and poor mountain pasture the problem is solved in a natural way, by turning the flock onto this thin grass where they must take abundant exercise by walking and climbing and will not find an excess of food. This is the natural way of preventing an excess of flesh.

It is not a safe plan to attempt reduction of flesh by over pasturing of small and fertile fields. The result is to cause the ewes to gnaw into the ground for the herbage there and parasitic infection is pretty sure to follow.

\section{THE USE OF RAPE.}

Rape belongs to the same order of plants as the cabbages and rape leaves have a similar taste and appearance as cabbages. On rich soil rape yields an astonishing amount of forage, which must be eaten green, as owing to its watery nature it can not be cured into hay. There seems a peculiar affinity between the cabbage family and the sheep. Common cabbages, 
thousand-headed kale, rape, swede turnipsall are greedily eaten and make good, healthful development.

Rape comes in to good play during the drouths of autumn and after cool, frosty weather has stopped the growth of grass in the fall. It may be sown in the corn at the time of the last working, using about three or four pounds of seed to the acre and letting the cultivator cover it. Should the season prove moderately moist thereafter the rape will come on and be ready to make a vigorous growth as soon as the corn is cut. By the middle of October it may be waist high over the field and will afford an immense amount of grazing until Christmas or later.

Care should be taken not to turn on rape early in the morning in late fall when it is frosted as every leaf that is bent at that time will blacken and decay. It takes a cold of about 12 degrees to injure rape if it is not disturbed until it has thawed again.

Sheep will fatten on rape though an addition of grain is profitable and access to a grass pasture or the regular feeding of good hay in connection with it is very desirable. There is some danger from bloat in rape feeding, though the writer has never had to treat a sheep for rape bloating nor lost one.

The Dwarf Essex seems the best variety to sow.

CABBAGES.

In fitting sheep for the show ring cabbages are almost indispensable and for feeding in fall and early winter they are most excellent. In 
many places cabbage grows luxuriantly and a given amount of sheep feed can probably be as cheaply grown from this plant as in any other way. In considering these foods it must be borne in mind that a certain portion of succulence is absolutely necessary to the sheep if it is to be kept in perfect health. It is less tronble to grow the common farm crops of grain and hay and sheep can be maintained upon them alone, but not in their highest degree of health and profit. There is also in the rape, turnips and cabbages some quality that makes for healthful growth of wool.

\section{PUMPKINS.}

Among the best autumn and early winter supplementary foods for sheep are pumpkins. They are readily grown in the cornfield or in a separate field by themselves and yield a large amount of feed to the acre. Our method of growing is to use pumpkin seeds to replant with in the cornfield, putting them in wherever missing hills occur. In this manner we have sesured as high as two tons of pumpkins to the acre without in the least injuring the crop of corn, provided the season proved favorable. In fact, the shading of the ground between the corn rows by the wide leaves of the pumpkin vines serves to help conserve the moisture when it is most needed and the corn is often the better for the association of the vines. It is safer, however, to plant pumpkins by themselves.

Pumpkins serve the flock in two ways: first, 
as a direct and healthful food of considerable nutritive value and yet never dangerous from excessive richness, and next from the direct medicinal value of the seeds. Pumpkin seeds are among the best vermifuges known. They should never be removed from the pumpkins but fed all together, and if fed in considerable amounts, the direct and immediate improvement in the flock will be very apparent. Tapeworms have never troubled the writer's flock in the least and no other reason can be attributed than the annual liberal pumpkin feeding.

The way to feed pumpkins is to strew them about the pasture without cutting them open at all, or at least cutting only a few of them. If many are cut the sheep eat only the soft inside parts at first, with the seeds, and might in this way get too many seeds for their good, whereas when they must gnaw a way into the pumpkin they will eat it up clean before attacking another. The pumpkins keep better to be scattered over the field than to be piled in heaps, at least before frost strikes them.

The secret in growing pumpkins is, first, to have the land rich, then to plant a great surplus of seeds. The striped-cucumber beetle revels on pumpkin leaves, and if not enough are planted for him and you also he will reap the entire harvest at an early date. They may be thinned after beginning to vine.

It is particularly desirable to have the ewe flock thriving and increasing in flesh at time of breeding. Not only will the lambs conceived at such a time be of superior vigor but 
there will be a larger number of twins among them.

CARE OF THE FEET.

When the sheep are turned to pasture in the spring their feet should be carefully trimmed and shortened. It is easier to do this, if they are permitted to go in the wet grass for a day or two and are taken in while their hoofs are yet soft. They will at such a time cut like cheese, whereas if they are trimmed when dry they will be very horny in texture.

Nature evidently intended the sheep for climbing over very rocky soil where the feet would be subjected to rapid wear. It is probable, too, that in selecting individuals for their superior wool growth the horn growth of the feet has kept apace with the wool growth in some degree, since there is a relationship between horn growth and wool. In any event it is very unlikely that with the amount of travel needed on arable farms the sheep will sufficiently wear down their feet to relieve the shepherd of need to trim them twice a year, and with some breeds more often.

Unless the feet are kept trimmed they will become deformed and the sheep will stand on one side of the foot, with the ankle turned over, giving doubtless some pain and a very awkward look.

The aim of trimming should be to keep the feet as short as possible, not to cut to the quick, so that they may be able to stand naturally and squarely upon them. It is probable that lack of trimming is in some degree re- 
sponsible for disease of the feet. Diseases may occur, unfortunately, even in feet that have been well trimmed, and the subject must have attention.

\section{FOOT-ROT AND FOOT-SCALD.}

The shepherd commonly makes a distinction between a simple contagious affection of the foot called foot-scald and the real and very serious disease, also contagious, called footrot. There seems reason to believe that there is a form of foot-scald that rapidly goes through a flock yet readily yields to treatment that is distinct from the more severe and less easily eradicated foot-rot.

It is the belief of the writer, however, that quite often the shepherd hides his genuine footrot behind the more harmless appellation.

There is, however, an inflammation of the skin between the claws of the foot that does not extend beneath the horny covering of the foot itself and that vields quite readily to a simple treatment of putting the sheep upon a dry footing, cleansing from filth and an application of some coal tar dip or carbolic acid.

When the disease has penetrated beneath the shell of the foot and there is found there a watery, evil-smelling exudation it is genuine footrot and should have immediate and thorough treatment, with preventive measures to preclude its spreading to the rest of the flock.

First, it is necessary to pare away all the horn that hides the diseased surface. The disease being one of germ origin, there is no hope 
of cure except through the complete destruction of the germs, and they must therefore be uncovered from their hiding. A sharp knife in the hands of a careful and thorough man is a kind thing to the afflicted sheep, even though it may cause some temporaly pain.

When once the diseased surface is laid bare it is only necessary to wet it well with a strong solution of blue vitriol (sulphate of copper), or butter of antimony, to bind it up if much horn has been cut away and keep the sheep on dry footing for a time.

It is necessary, however, to prevent the spread of the disease through the flock. To do this all feet should be carefully trimmed and any sore ones given individual treatment. Then a trough 6 " wide in the bottom, 12" wide at the top, 12" deep and about $10^{\prime}$ long should be made of three two-inch planks. This must be enclosed with hurdles so that the sheep may be compelled to pass through it. The writer has fastened such a trough at the door of the sheep barn so that in order to pass out the flock must pass through the trough. Then it was only necessary to confine the flock for a time and they would of their own accord go out, each one walking through the trough.

This treatment was given daily for a week or so, as it took little of the shepherd's time and was inexpensive. By this means foot disorders were eradicated from the flock after having caused much trouble.

In the trough was placed a simple lime whitewash, in which was sufficient blue vitriol to give 
it a blue color. 'This effectually prevented the spread of the disease and cured many cases in their incipiency.

In no other business is it more true that "a stitch in time saves nine" than in the care of sheep.

It is unfortunate that the average American shepherd sells out when foot disease strikes his flock when he can so easily control and eradicate the disease. Troubles must come in all endeavors, so when one has been suffered and the remedy therefor found it is not a reason for abandonment of enterprise but the more reason for continuance, rather than to "fly to troubles we know not of."

ADYLNT OF LATE LAMBS.

There are situations where it is desirable that lambing should be delayed until grass comes. When forage and grain are scarce and the means not at hand to well nourish the ewe after lambing until grass connes, when indeed grass is the chief asset of the shepherd it is wise to time the lambing so that the lambs will come at about the same time as the grass. Indeed a lamb dropped then will make a far better growth than one dropped weeks earlier from a poorly-nourished ewe half starved by its mother because she cannot give it much milk before she herself has been fed. Nor will such a ewe respond in her milk flow to green grass as she would did her lamb come after grass has started anew in her veins a vigorous coursing of the vital fluid. It is most wise, however, to see to it that 
these late lambing ewes are strengthened by some supplementary feeding before the lambs appear. A little grain fed then will repay its cost several times, for the well-nourished ewe goes easily through the pains of lambing and loves well her offspring if she has milk for it inside her udder.

The shepherd who herds on grass may have the lamb crop all born within a very few days. They will be anxious days while they last, but the agony is soon over, seeing that this is $\mathrm{Na}$ ture's time set for this miracle to take place, and the ewes naturally conceive readily to lamb then. Great watchfulness is necessary and there are certain helps that may be mentioned.

\section{THE LAMBING 'TENT.}

Many Western sheep owners use small shelter tents about 4.2 inches square, supported by curved iron rods, to shelter the ewe and her lamb from storm. These tents are readily carried and set over the ewe any where. They serve to keep her and her offspring together while they are becoming acquainted and by turning the chilling rain save many lambs that would otherwise be lost. As these tents are inexpensive and can readily be made by the shepherd himself some of them should be at hand when an early lambing on grass is planned.

It is desirable to scatter the flock as much as possible at this time, for then the ewes are the more readily kept track of and their lambs are not so often lost through mixing and straying 
from their mothers. This latter is particularly dangerous in case of twins, seeing that the ewe is often content if she has one lamb with her and looks for the other very little.

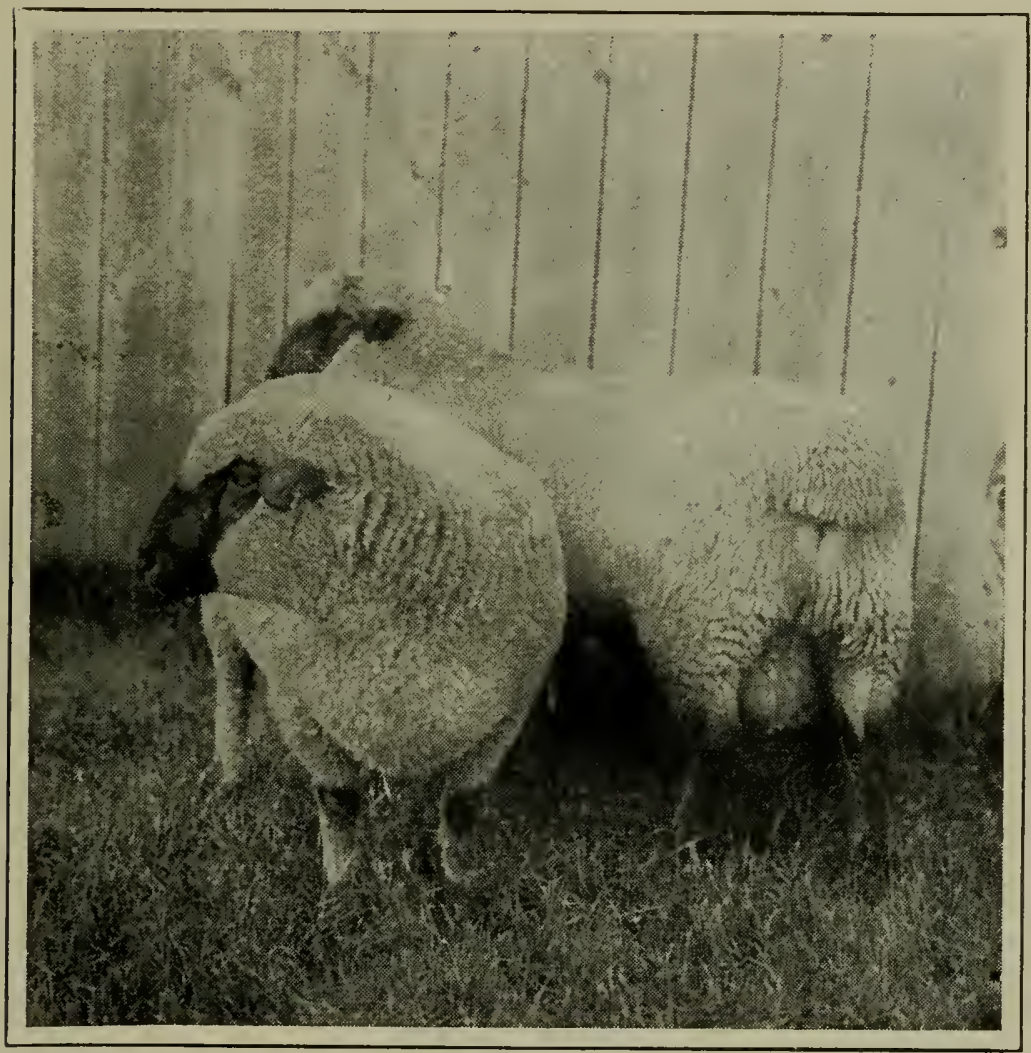

IMPORTED HAMPSHIRE RAM LAMBS.

There are exceptions to this rule however. The writer has known Dorset ewes that seemed to have perfect memories and a knowledge of numbers and would seek as earnestly for a strayed twin as though it were a single lost lamb. 
Seeing that the ewes at this time must give their attention to their lambs and canrict wander wide in search of food, it is a good plan to lamb them on some specially good piece of grass. And to aid in keeping them quiet the shepherd may carry with him oats, giving a handful to the ewe wherever he finds her. It is hardly probable that a larger per cent of lambs will be saved by lambing on grass than by lambing earlier, nor will they ever be so good as early lambs pushed from the start, but they may be produced with comparatively little trouble and in some situations are the only ones that it is practicable to produce.

No lambs should be permitted to be born later than the first of May, except in a high mountainous region where grass starts late and cool summer weather prevails. Lambs born in May, June or July seldom amount to much, owing no doubt to the fact that they are almost sure to become infested with parasites. Between April and September, then, there should be no lambing done. Rather than to lamb out of season the ewe should be allowed to go over open and she may be bred in the spring for fall lambs.

\section{FALL LAMBS.}

The best sheep are developed from fall-born lambs. They may begin to come in September. From this time on till winter the conditions are excellent for their growth and development. The weather then is favorable, food is abundant, the ewes are easily made to milk largely and 
instead of the weather becoming warmer and more oppressive it becomes steadily more and more stimulating to the lambs. And, best of all, there is little danger of parasites at this time. The fall lambs come out in spring half matured and able to go safely and healthfully through the trials of summer. Or if they are sold at the market they bring long prices in winter time. It is not altogether easy to get ewes to lamb in the fall. Certain breeds refuse altogether to do this, but with some of the Merinos and their grades and the Dorsets and Dorset grades it is not so difficult of accomplishment. To get the ewes to breed in spring the conditions of fall must be complied with as nearly as possible.

First, the ewes must have their lambs of the previous crop born as early as possible so that they may be weaned and new strength gained from a term of rest.

Next, they must be sufficiently well fed so that they will feel an ascending current of health throughout their veins.

They must have the ram turned with them before warm weather comes on. April and May are the months in which to breed ewes for fall lambs.

The rams must not as a usual thing be permitted to run continually with the ewes at this time. If they do they themselves soon acquiesce in the idea that it is an unnatural time for breeding. It is wise if the ram can be kept up and turned with the flock for only an hour or two each day, as described in earlier pages 
of this work. Or two rams may be used, their rivalry inciting them to extra exertion.

There is no doubt whatever that the breeding instinct is in part a result of mental processes that may be stimulated by suggestion. This is almost as true of the sheep as it is of higher races of animals. The ram that persistently courts the ewe may after a time so divert (by his suggestion) blood to her reproductive organs as to cause her to come in heat and conceive at a time when naturally these organs would be in a dormant condition.

If the shepherd does not care to risk the uncertain mental influence of the ram he may practice holding the ewe and compelling her to accept the attention of the ram once. This often supplies stimulation enough to cause her to come naturally in heat and to conceive at the later service.

Fall-born lambs in America have developed into as fine sheep as ever were produced in England. This is true of few lambs born in spring, no matter how skillfully they have been treated. Fall-born ram lambs make fine strong fellows when they are yearlings and ready to go into service. 


\section{CHAPTER VII.}

\section{WASHING, SHEARING AND MARKING.}

The washing of sheep to remove the surplus oil in the wool was once a universal practice. It was one of those old practices, like putting "redding" on the fleeces to make the sheep look attractive (?) that are hard to account for. The washing did not prepare the wool for manufacture nor render it more easily scoured by him. It did, however, render it lighter, and therefore the buyers found washing to their advantage.

At the present time few sheep, comparatively speaking, are washed before shearing. It may, however, be profitable in some localities where buyers discriminate sharply against unwashed wool to continue to put the sheep through the water as of old.

If the sheep owner can find a buyer who really knows his business and buys honestly, he will get as much for his fleeces unwashed as washed, and can therefore save himself the disagreeable task and the flock the injury that such a shock is bound to inflict.

One serious disadvantage of washing is that it can not be done safely and comfortably until the advent of warm weather, whereas the flock 
should be shorn much before that time, unless it be a hill flock running without shelter.

The writer, living on the fortieth parallel, usually shear's his ewe flock the first week in April and sometimes the last week in March.

There are several advantages of this early shearing. About this time ewes that have been well fed often experience a little loosening of the wool, as though it were time to shed it off, and locks will be lost, particularly about the neck.

Then the advent of warm days causes a feeling of languor and the sheep do not eat and thrive as has been their wont. And again, there are many showers in April and the flock with fleeces on literally "has not sense enough to come in out of the rain" and the fleeces become drenched and heavy. Then they keep their lambs out in the rain, whereas if they were shorn they would flee to their sheds as soon as the first drops struck them.

Any one who has once tried this early shearing will continue it. Should the flock be poorly fed, however, and unsheltered, the fleeces should be left on until the middle of May.

The amount of wool taken off in a period of years will probably be nearly the same whether shorn in April, May or June, with the probability that the early-shorn sheep through their greater vigor and healthfulness may shear the most.

For washing sheep a considerable body of water is required. It is usual to take advantage of a creek or natural pool. The sheep are immersed, the wool squeezed a little be- 
tween the hands and they are permitted to go out and drain themselves on the bank. No soap is used, as the oil of the wool is itself readily dissolved in water, and it is this oil only that is sought to be removed. It is usual to allow ten days or two weeks to elapse after washing before the sheep are shorn; and, in fact, it is not easy to shear them as soon as they are dry owing to a difficutly in penetrating the wool with the shears until more oil has been secreted in the wool.

\section{WASHING AND SHEARING.}

The dipping tank can be used for washing sheep, but not unless there can in some way be secured a continuous stream of water to flow through it. The sheep should not drain back into the tank in case it is used. It is to be hoped that this custom of washing will soon be one of ancient history wherever sheep are grown.

Some sheep owners have their fleeces tubwashed after being taken from the sheep's back. This is not difficult to do, only that the drying is slow and it ought not to be necessary.

\section{SHEARING.}

The shearing of sheep is an art not to be immediately learned by the novice. It requires several seasons' practice to make an expert shearer of a man. There is, unfortunately, a scarcity of good shearers in all our Eastern states. It is a trade that any vigorous young man may learn with sure expectation of making good wages for some weeks each season. A 
good shearer will shear from 45 to 100 sheep in a day, using common hand shears. He will get for his service from 4 to 10 cents each, perhaps 6 cents being the average price.

The shearing place should be in some light, airy part of the barn. A clean platform on which to work is necessary. If nothing else is available, since sheep barns have usually the natural earth for floor, a spare barn door may be taken from its hangings and laid down for temporary use. A small pen close by holds enough sheep in readiness to keep the shearer busy for some hours.

In back regions it is customary to tie the legs of the sheep, place it on a low platform or box and set two men, or one man and a boy at work cutting off the fleece. This is a childish and unskilled method that should not be imitated.

The sheep is a peculiar animal, directly sensitive to touch. Tie the legs, or even touch them, it responds by struggling to be free. Turn it so that it can not get its feet to the ground and its struggles cease, as though it knew the hopelessness of struggling.

Following this thought, if one attempts to hold a horned sheep by the horns it continues to struggle and can not seem to understand why it is not free. It can not feel the press of the hand upon the horn. Hold the same sheep by a touch under the chin and if it has had a trifle of training it, feeling your hand, yields and stands dutifully.

The shearer then, without tying the feet, turns the sheep upon its rump, with its head 
and shoulders resting against him, supported by the left arm and with the shears in the right hand opens the wool, usually on the right shoulder, and proceeds to clip it away, keeping it as much as possible in one piece. That is, he strips it away easily and gently as he would remove a coat. It is essential that he so bend the sheep's body that the skin will be at all times tight. If this is done it is easy to cut the wool closely and there is little danger of cutting the skin.

When the wool is removed all very dirty pieces should be separated from it and never tied up with the fleece. There is need of honesty in tying wool and nothing but wool should go inside a fleece. The fleece is rolled with the belly and loose ends inside, the cut fibers out. It is tied, not too tightly, with special wool twine wrapped twice or at most three times around.

The use of binder twine or any but special wool twine greatly injures the wool, as the small bits of fiber get in it and not taking dyes must be picked out by hand. This occasions a loss of sometimes as much as 5 cents per pound which must eventually come from the producer, since manufacturer's learn what sort of stuff is to be expected from some regions and bid for it accordingly.

There is no need of a box or wool table for tying a very compact bundle since buyers prefer the ordinary, rather loosely tied fleeces.

SHFARING MACHINES.

The use of machines has now become quite 
common in shearing sheep and they are sufficiently well perfected so that they do their work with little trouble from breakage. It is far easier to learn to shear sheep with machine than by hand, though old shearers prefer the hand shears and can shear as many sheep in the

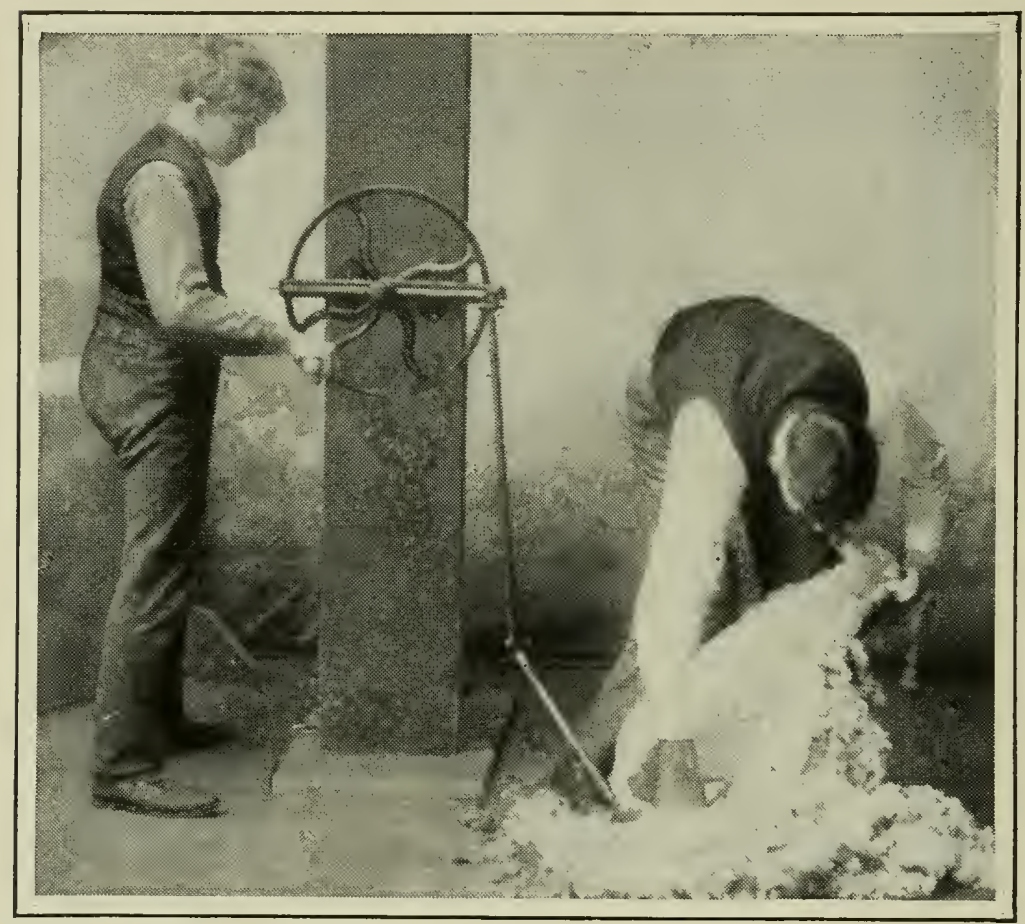

HAND-SHEARING MACHINE.

old-fashioned way as with the machine. Not so, however, with the novice; he will shear twice as many with the machine as he will with hand shears.

Then the work is far better done with the machine. There are no cuts from shears and the 
fleeces are taken off closely and evenly. There need be made no second cuts, which cause short fibers, little better than shoddy.

The machine shears in careful hands will cut in two every tick and leave the sheep clean of that vermin.

Against its use is the cost of the machine, about $\$ 15.00$ for a hand machine, and the cost of repairs. If well oiled and cared for, however, it will last for many seasons with occasional renewal of cutting parts.

Then there is needed a boy to turn the crank, so that its use requires two persons to shear a sheep. As the boy is unskilled and may usually be had for a small sum this is not important. Altogether the writer advises the man who has not available skilled shearer's of the old-fashioned type and does the shearing himself to use the machine. If he must hire shearers he had better let them furnish their own tools.

There are power machines for large plants. These are operated very successfully by gasoline engines and there are small power machines with two or more sets of shears. These are entirely practical but it is not usually profitable to install a power plant for fewer than 1,000 sheep.

When sheep are to go to market after being shorn the machine is a saving since it takes off more wool than hand shears can. The saving is from 2 to 8 ounces. A saving of 4 ounces, or $1 / 4$ pound, would pay the cost of shearing. All sorts of sheep are shorn by machines, though 
they work especially well on Downs, LongWools and Dor'sets. They are difficult to operate on Western lambs that have been dipped and placed on feed in winter, owing to the peculiar condition of the wool which seems to be affected by the shock of transportation and dipping and to be dead at that point and consequently hard to get shears into.

A fat sheep nicely shorn with the machine shears is a very attractive object and appears fatter than when shorn by hand.

The shearing machine should not be used in midsummer, or if it is it should not be set to run very close else there will not be enough wool left on to protect the sheep from flies and sunburn and it will suffer severely before the wool has grown out again.

It is in some situations a good plan to shear a flock of ewes twice a year, once very early, say in late March, and again in August. The wool will not be quite so valuable, for it will be shorter, but the relief to the sheep in getting rid of its warm coat at this sultry time is remarkable and it will thrive far better than unshorn, lambing stronger if it is to drop fall or early winter lambs and conceiving earlier if it is not yet bred. The writer has practiced this and has not had to take more than one cent per pound less for his short wool, which loss is not worth mentioning when the advantage to the flock is considered.

It is a custom of some shepherds and feeders to shear sheep and lambs before placing them on feed in the fall and early winter. 


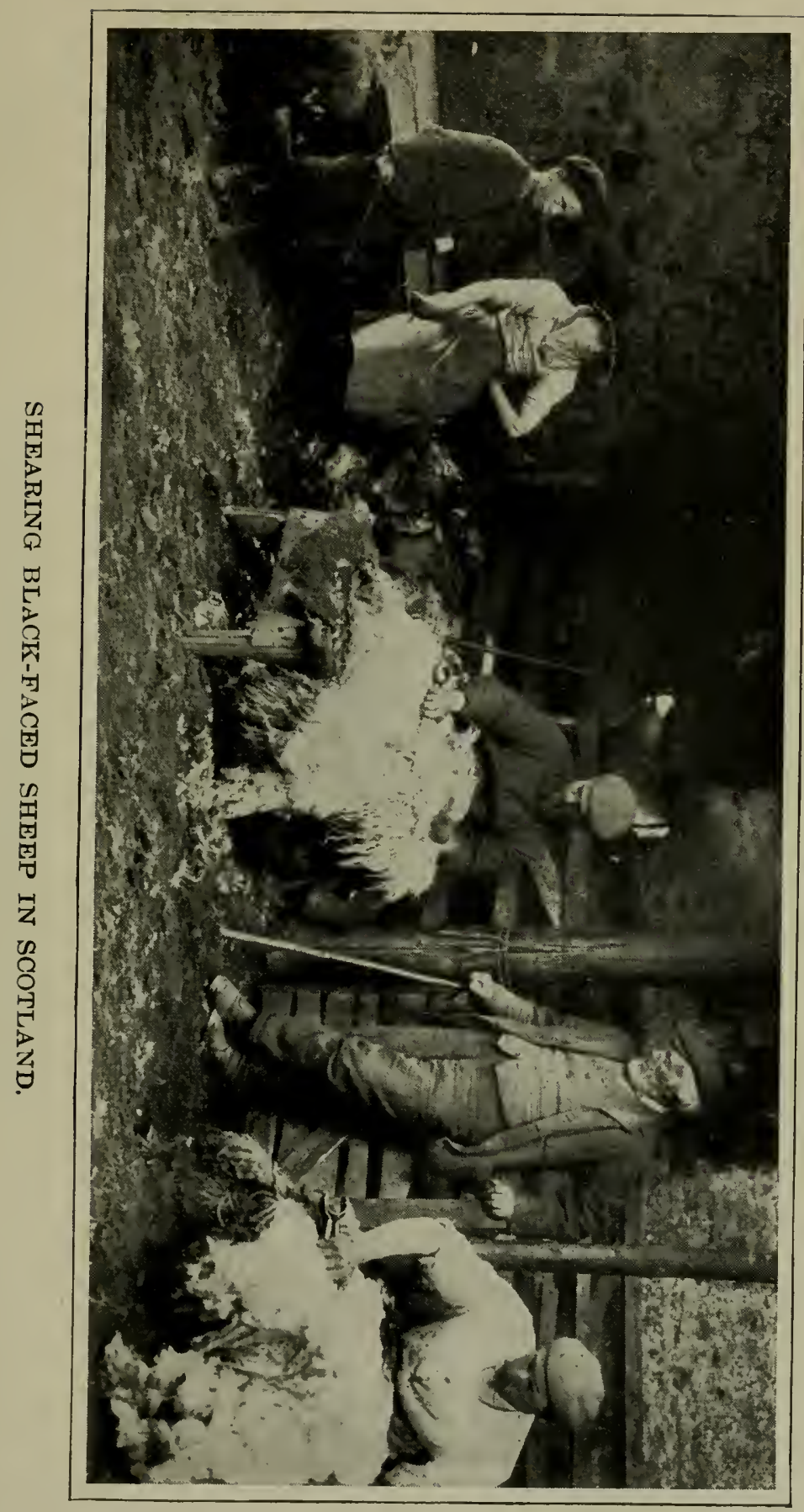



There is little advantage in this. It forces and crowds them close together and they do not gain any better.

The one advantage is that it is easier to free them from ticks after they are shorn and if they are dipped less fluid is required.

MARKING.

When sheep go to pasture it is well to have a mark upon them so that in case they accidentally become mixed with other sheep they may be known.

A large letter made of wood, with a handle to it, is used, some thick paint serving for ink. Iinseed oil and lampblack make a durable mark, plainly seen.

Permanent marking is done by splitting, cropping or notching the ears. This is the universal custom on Western ranges, but such disfigurement is seldom practiced in the Eastern states. There are metal labels that are inserted in the ears; these bear the name of the owners, or number's, or the numbers assigned to registered sheep by the breed secretaries.

There are various forms of these metal ear tag's. None of them is absolutely sure to remain in the ear. The difficulty is that the ears become sore and pus formation eats away so much of the tissue that the labels drop out or they are caught and torn out by some branch or nail. They may remain in place for years and they may become lost in a short time. There is a right and a wrong way to put these metal tags in. 
The right way is to use a punch, cutting out an oval bit of the ear tissue and to make the hole some days before the label is inserted, giving the ear time to heal in the meantime.

Then the hole must be so carefully gauged that the label will not compress the ear, yet will fit snugly and present little of projection to catch and cause it to be torn out. If this course is taken most of the labels will remain in place.

\section{THE TATTOO MARK.}

The best method of permanently marking a sheep is by the tattoo mark. This is especially applicable to sheep with light-colored ears, though it is used on some of the Down breeds.

The tattoo properly put in is absolutely permanent It does not annoy the sheep and once put in is a sure record as long as the animal lives.

There are sets of tattooing instruments sold by dealers in shepherds' supplies. These consist of a frame with handles like pinchers in which are set removable letters and numbers. These letters and numbers have a great number of sharp points, forming the characters, and the handles when closed cause these points to prick the required characters.

India ink is the pigment used and when pressed into these minute wounds remains there, leaving an indelible black tracing. There is danger of the careless or inexperienced operator making failure with this tattooing outfit, for certain things are essential. The levers must be so adjusted that when closed the points 
will prick evenly the required characters in a thick sheet of paper or cardboard. If any do not make their mark the instrument is out of adjustment or the letter's worn out. These points rust if not kept oiled when not in use.

Then in placing in the letters or figures one must be sure that he has them in right. They are like type, reversed, so that it is puzzling at first to the operator to use them and it is well to test them on a bit of cardboard before using them on the sheep. After once the mark is in the ear there is no erasing it.

Then there should be used a great abundance of the india ink, smearing as much on the points as possible and afterward rubbing more in the ear with the finger. If once the pricks are made in the ear and the ink rubbed in them the deed is done and will endure.

In England there are men who make a business of marking sheep with the tattoo mark. It is the official marking of a number of breeds and the Secretary often attends in person to the marking. It is the most desirable mark for any pure-bred sheep that is to be retained as a breeder, though it is hardly necessary to use this mark on stock sheep that are soon to be fattened. It may, however, save much dispute if all stock ewes have their owner's mark, seeing that they may become mixed on pasture.

\section{MAPKING PURE-BRED LAMBS.}

When lambs that are pure-bred are to be registered it is essential that the shepherd so mark them at an early age as to identify them 
later according to their parentage. This is by no means an easy task. A very small lamb can not safely carry a mark in its ear and there is a little trouble later on in discovering which ewes are the mothers of the lambs.

The writer has found a good plan to be to let them run until they are well grown, but still sucking, then separate them from their mothers some morning and keep them apart until they are eager for association with their dams. Then the lambs may be caught one at a time, and in one ear a tattoo number be put. This should be in the opposite ear from where the permanent number is to go. These number's may begin each year at No. 1, running up as high as necessary.

Having put the number in the lamb's ear and entered it in a note book it is placed with the ewes, where it soon singles out its mother and while sucking she is caught and her number noted and entered opposite that of the lamb. A name may be given the lamb at the same time, though individual names except for exceptionally good lambs are hardly worth while. It is easier and as well to designate them simply by numbers, identifying them with the name of the breeder's or the farm, as "Jones' 99" or "Woodland 174."

Of course these permanent numbers must be consecutive from year to year else the Secretary would find duplicates in his records.

After the lambs have been weaned and are sufficiently developed to indicate which are worth permanent record their records are sent 
to the breed Secretary and he records them and sends with their certificates the Association number, which must be placed in the ear left blank for that purpose.

Care must be taken not to make confusion by using occasionally the wrong ear, and it is well to use numbers of different size for this first marking. If they are a trifle larger than the permanent numbers it is well, seeing that the ear will grow, and if they were made a little smaller they would in time become of the samc size as the ones later put in.

The writer is of the opinion that shepherds are usually very careless in assigning mothers to lambs for record and guess more than they should.

The English system is to record the individnal rams and the ewes by flocks only. Seeing that they have achieved glorious results in the development of breeds by their course it would seem presumptious for the American breeders to claim superiority of method. The writer unhesitatingly declares that the English system should be adopted on this side of the water and sees but one objection to it, that, perhaps, a fatal one, that in recording by flocks men are not compelled to pay much for the support of the breed association. In England this is done largely by subscription and liberal annual dues: here by charging $50 \mathrm{c}$ each fồ recording individual sheep. The English system would relieve the secretaries of a vast amount of drudgery that seems to have accomplished very insignificant results. 


\section{CHAPTER VIII.}

\section{FLOCK HUSBANDRY IN THE WESTERN STATES.}

\section{NEW MEXICO.}

The management of flocks upon the great ranges of the West varies considerably according to the climate and topography of the country and according to the character of the men engaged in the industry. Probably the oldest sheep industry in the United States was founded in New Mexico by the early Mexican colonists of Spanish and Indian origin. There are in New Mexico vast plains ranging from 4,000 to 8,000 feet in altitude, interspersed with mountains and canyons. These plains are generally covered with a rather thick, short grass of considerable nutritive value. The climate is dry and moderately cool, especially at night.

The days are almost uniformly sunny and warm.

The native Mexican sheep found there in its purity is becoming more and more uncommon, owing to the steady introduction of Merino blood. There has also been introduced here more or less blood from the English breeds but as a rule the Merino has been found to cross 
better and to withstand the conditions better than the mutton breeds.

Management on most of these Mexican ranches is extremely simple. Native Mexican sheep owners often use corrals (small yards built of cedar or pinon posts set close in the ground) in which the flocks (called "herds", throughout the West) are confined at night. This secures them from loss from coyotes or mountain lions. The corralling is however, a serious injury to the sheep since they must travel some distance to and from the enclosure and what is worse must await the pleasure of the herder before they can go forth to graze in the morning.

\section{CHARACTER OF MEXICAN SHEEP.}

The native Mexican sheep is indeed a "sorry" animal, having few characteristics that we are wont to associate with good form or character. It has a thin neck and feeble look, a curving back, round, contracted belly, thin legs and rather woe-begone countenance. The wool is coarse and scanty, the bellies and legs being often bare. And yet the Mexican sheep is not without its peculiar virtues.

It is fairly prolific and the lambs are hardy. It is a great traveler and can subsist upon scanty and dry forage. When worst comes to worst and in the lower country along the Rio Grande, far down in Texas and across the river in old Mexico rain does not fall and all herbage is dried up and turned to dust, the humble Mexican still subsists upon the tender ends of 
twigs, upon ractus joints, upon the withered grass growing between the cactus bunches and upon dry weeds that have blown by the wind across the plains. They may become rery much emaciated but seldom perish. The Mexican ewe when mated with a good Merino ram pro-

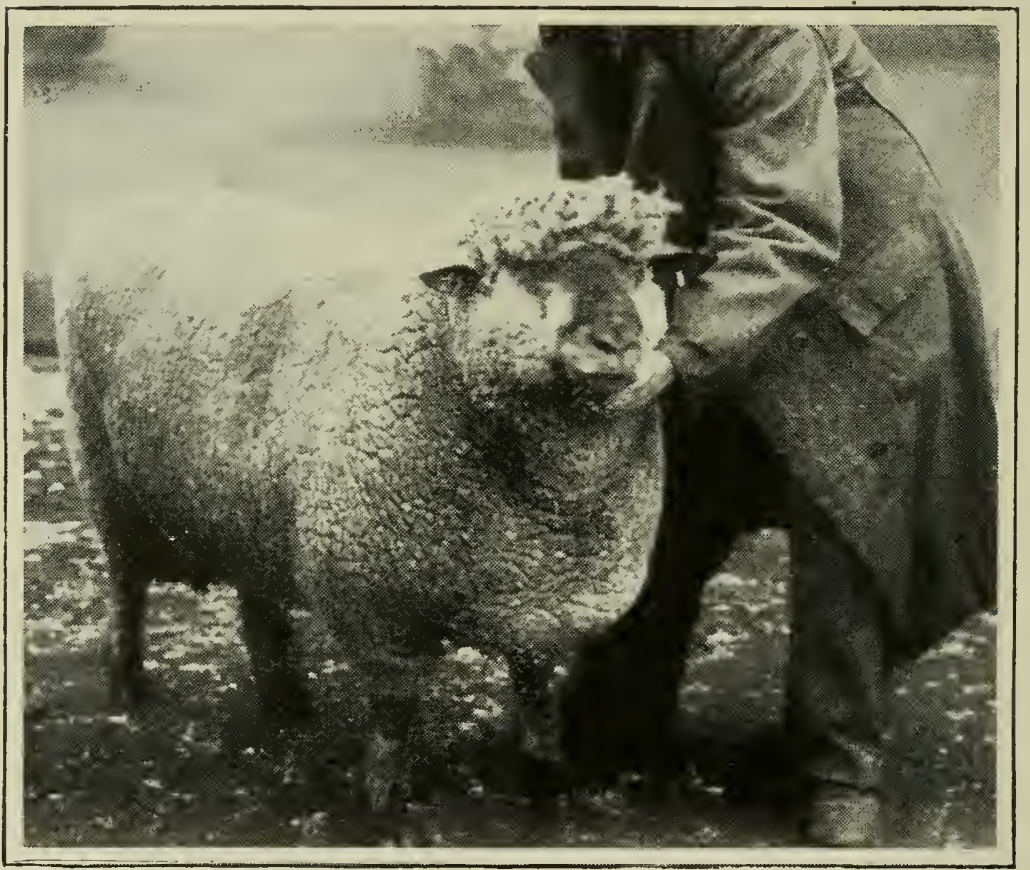

YEARLING OXFORD RAM

duces an offspring far superior to herself and with a second cross upon this foundation very serviceable flocks are established. Indeed a very great number of flocks throughout New Mexico, Colorado, Arizona, Utah and California have been bred up from a Mexican basis. 
After the infusion of Merino blood the use of some of the mutton breeds produces an admirable lamb, sprightly, a good feeder, healthy and rugged. There will occur, however, a good many cases of reversion to type, when the Mexican character will crop out, modified, but not destroyed by the foreign bloods.

\section{THE "GOOD OLD TIMES" IN NEW MEXICO.}

Under the old fashioned regime in New Mexico not much improvement of the herds was possible. There was no provision for winter feeding and there often occurred a somewhat long period of semi-starvation. Water was not readily accessible and often of execrable quality, being supplied by shallow pools or lakes that became incredibly foul and dangerous to drink from. There is now a considerable number of men engaged in sheep growing under better conditions. Near the irrigable valleys vast amounts of alfalfa are grown and winter feeding is practiced to some extent. Better rams are used than formerly, the Rambouillet having been used to a considerable extent, together with Delaines and other Merinos. In some places Shropshire and even Cotswold blood has been introduced. Native Mexican sheep owners have in many instances given way to American owners and in other instances have themselves learned better methods. A peculiar industry of this region, especially down along the Pecos river is the lambing of ewes in the alfalfa fields in March or earlier, and growing the lambs rap- 
idly with grain and green alfalfa for early marketing in May and June.

\section{MODERN MANAGEMENT.}

A herd may contain from 500 to 3,000 sheep. Perhaps 2,000 would be considered a good sized but workable herd in New Mexico. At lambing time the ewe band is divided, not more than 1,000 being together. Good shepherds seldom use the corral at night, since its use is almost certain to bring a steady deterioration in a good flock and prevent the improvement of a bad one. Instead of the corral the sheep are driven at evening time near to the tent of the herder and watched for a little time when they finally lie down in a compact body. They are then said to be "bedded down" and will remain there quietly until morning unless the moon happens to be very bright, or something occurs to frighten them.

It is usual to have bells upon a number of the sheep. The herder in his tent close at hand hears the jingle of the bells if the sheep start to move off and goes around them or sends his dog. Soon the habit is formed with great fixity of "bedding down" regularly close to thoir herder and they do not often try to stray without serious provocation

Very early in the morning the herd awakens and unless there is a storm threatening, of which they have instinctive fore knowledge, they will go out to graze. The shepherd, or "sheep herder" as he is often called, directs them to the one way or the other according to 


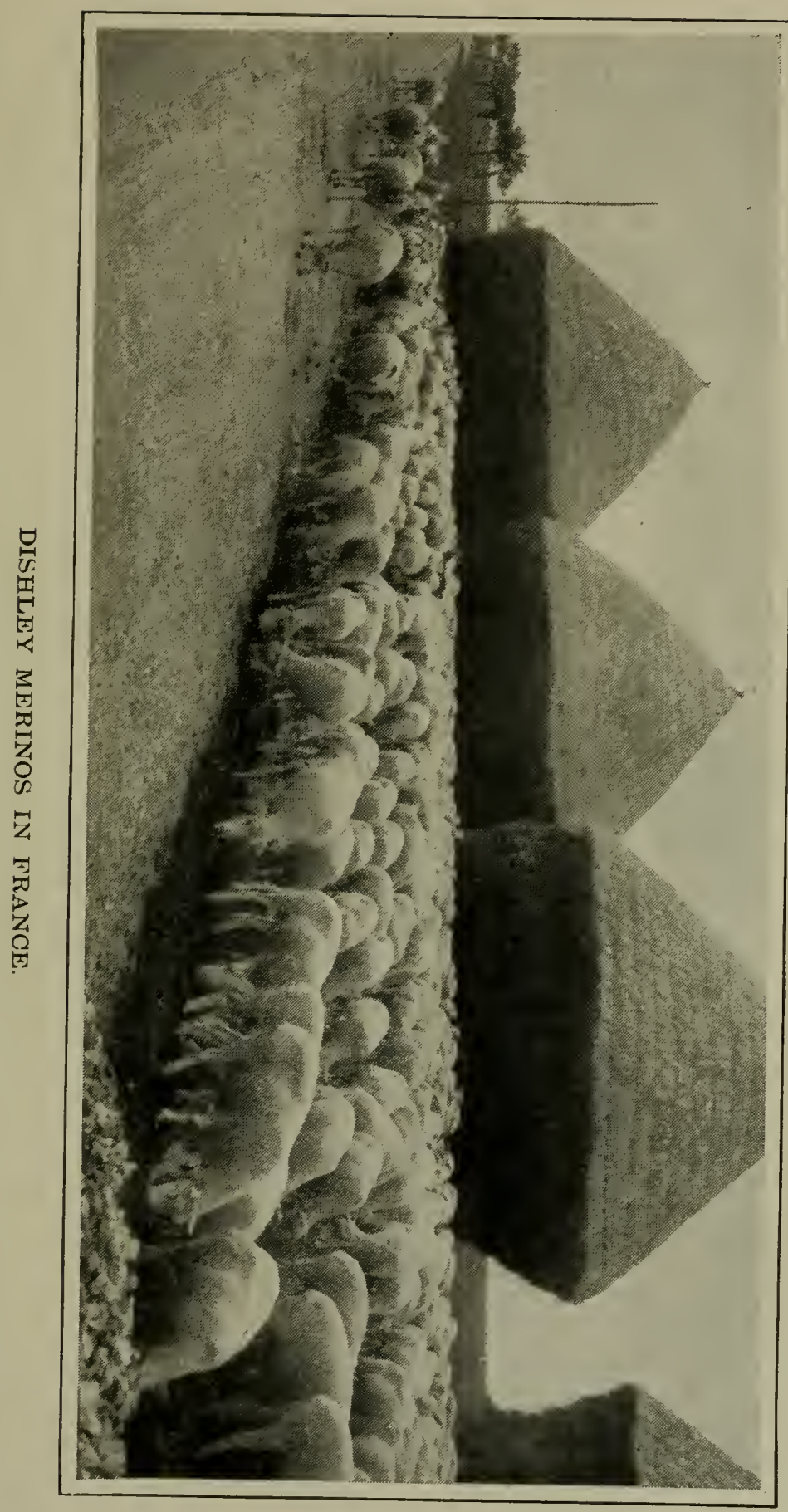



the conditions of the range, and swallowing his rather hastily prepared breakfast sets out after them to see that they do not scatter too wide or go too far. At noon he may return to his tent and prepare his midday meal and perhaps the flock will lie quiescent for some hours if feed is fairly abundant and there is shade of trees or rocks.

As evening approaches he gathers them together and follows them to their bed ground again and thus has closed the labor of the day. The work is not usually laborious but it calls for faithfulness and considerable patience and to be a really first-class "sheep herder" requires a deep insight into the ways of sheep and of all wild Nature as well.

\section{DISEASES OF THE RANGE.}

Sheep in this region are healthy except for two principal troubles; scab, which was once almost universal, and stomach worms or "lombriz" which are occasionally destructive to lambs. Scab is very difficult to eradicate on ranches where corrals are used continuously and where flocks stray about and cross each other's paths and especially if they alternately use certain corrals. Of recent years, however, many herds have been made completely clean of scab and there is hope that all may be rid of it in the near future.

That scab is not a necessary adjunct of range sheep the writer has amply proved, having completely eradicated it from his own herds when engaged in ranching in Utah. 
Stomach worms, (Strongylus contortus) infect flocks that drink from shallow pools where to avoid the filth the sheep and lambs wade out till the water comes to their bellies, depositing there more g'erms of whatever parasite they may harbor. There would be no stomach worms in these regions if sheep watered at clean drinking places, or at least the number would be greatly restricted.

\section{MLENICAN LAMBS AS FEEDERS.}

Mexican lambs have been favorites among Colorado feeder's ever since they commenced their feeding operations in that region. They have found their death losses comparatively low from the Mexican lambs and that with a given amount of feed they make good gains. When fat they sell well because they dress well, and their small, light carcasses are in favor with local retailer's of mutton. They are doubtless often palmed off on Eastern buyers as "spring lambs." Brought to Ohio the writer" did not find them as profitable feeders as lambs from Utah, Wyoming or Montana, making much smaller gains and shearing very light fleeces.

Some of these Mexican ewe lambs (having one cross of Merino blood) were kept on an Ohio farm and bred to lamb. They did not by their performance indicate that they were desirable stock for Eastern conditions. The writer thinks the sooner the half wild "Mexican" blood is bred out of these sheep the better save for very hard conditions of drouth and thinly-grassed ranges. 


\section{THE WANDERING HERDS.}

In Utah, Nevada and parts of Colorado and in Idaho (with also a part of Arizona and California) a peculiar system of sheep ranching prevails. It might be called the nomadic, or trailing system, for the herds spend their summers on the high mountain pastures, their springs and falls in intermediate regions and their winters in the low-lying parts, on the deserts and foothills. Some of the better caredfor flocks are fed during part of the winter or spring on alfalfa or other hay grown in the valleys.

'These trailing bands of sheep are in charge of herders each having in his care from 2,000 to 3,000 except during lambing time, when he is given a smaller number and very often has help in addition. We may start with them in spring, when their journey begins from the desert toward the mountains. All winter they have lived on desert herbage and brush and snow has been largely their reliance for drink. When that is melted and the water holes are dried up the sheep must come out of the desert and head toward their mountain ranges. Very often these ranges are a hundred miles away and in rarer instances they are much more distant. 'The herder moves the band each day by slow stages towards their destination, taking care to visit each promising spot along the way where perchance food may be found. This forage may be of green grass quick grown from the melting snows and genial sun, which even 
in March shows a fervor unknown in Eastern lands, or it may be the young shoots of rabbit brush, willows and sage with an admixture of weeds.

The herder usually has a wagon equipped with a canvas cover, stove and commissary. In this, his home, he is established and with it he journeys in a desultory fashion, searching right and left for subsistence for his flock. There is a steadily intensifying spirit of opposition to the nomadic sheep men on the part of local settlers along streams and in the valleys of these mountain states, since the herds eat the grass that would naturally belong to settlers' horses and cows, and because they sometimes pollute streams that must serve as drinking water for the settlers and their animals.

\section{WAITING FOR GRASS TO COME.}

The herder can not hasten toward his coveted destination, for when by drouth he is driven from the desert the snow is yet covering his summer range, hence there may be a trying period of journeying with occasionally very short feed. In fact journeying flocks not unfrequently camp on each other's bed grounds, one after the other in succession sometimes to the number of half a dozen. The last comers find little to eat save the roots of the grass.

This habit of roving prevents the sheep men from having any very great regard for the preservation of the range and makes it difficult for them to preserve it even should they desire so to do. In truth there are regions where nomadic sheep have changed a once well grassed 
FLOCK HUSBANDRY IN WESTERN STATES. 217

country into one almost bare of grass and containing no forage other than comparatively worthless brush and weeds.

Lambing is usually delayed until the flocks are established upon their summer range, since it is difficult to move ewes with young lambs without great loss. It is a happy moment when after very great trials and toil the flock reaches

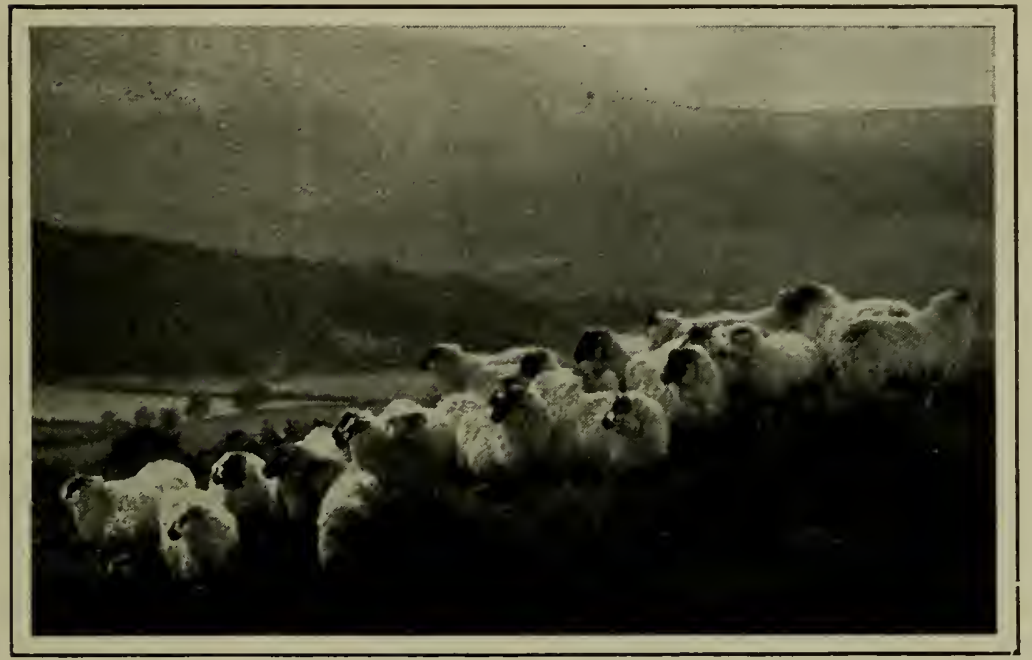

BLACK-FACED SHEEP IN THE HILLS.

the high mountain pastures, the snow is found to be gone and green grass abounds. Then there is long rest before distant journeying must begin again. The moves are of only a fer miles each and camps may remain for days and sometimes for weeks without being moved. The weather upon these green mountain pastures is stimulating and delicious; there are lovely groves of aspens and cool pine woods intersper- 
sed with flower-decked grassy glades. The lambs are born here and start into vigorous life and growth, far exceeding that of lambs born on lower altitudes on the plains of New Mexico.

From some of these mountain ranges come the best and fattest lambs that reach the markets of Omaha, Kansas City and Chicago, beginning in August and continuing until cold weather. Idaho especially and Utah are noted for their fine lambs.

\section{THE BLOOD OF THE HERDS.}

The basis of the flocks of this region is Merino but there has been added a great deal of mutton blood, where the ability of the range to produce fine lambs has been recognized. The Cotswold has worked great changes in Utah and some adjacent territory. Shropshires have been used in many places. Hampshires have been introduced also and upon good ranges and in the hands of generous men, able to give good care and liberal feeding, they have proved worthy.

THE DIVISION OF THE RANGES.

There is at present a general move upon the part of sheep owners in these mountain regions to get in some way possession of parts of their langes. They seek ownership of the summer range, or of parts of the fall and spring ranges, and are establishing farms where forage may be cut and stored for winter use. There is a large body of good citizens engaged in the sheep industry in these regions and also unfortunately some of the most selfish and degraded 
of men. A nomadic sheep herd under the management of an ignorant, lawless and irresponsible man is a curse to any land over which it travels. It sheds off scab germs to infect other herds so unfortunate as to follow in its trail, it pollutes streams, devastates young forests and destroys the range by over pasturing. It will indeed be a happy day for all this region when the land is divided up owned or leased by the cattle and sheep owners and the era of destruction of that beautiful region ends and reconstruction begins again. It is a short-sighted policy of our National Government that permits ranges to be devastated and refuses leases that would tend to preserve them and thus enrich all the community.

MONTANA, WYOMING AND THE DAKOTAS.

These regions possess a distinct character and have a type of sheep husbandry of their own. They are characterized by very wide, well grassed plateaus or plains, somewhat destitute of trees or brush and sometimes devoid of hills, canyons or natural shelter. The climate is much milder than it would be in a similar latitude in the Eastern states and while very low temperatures are often reached in winter, some times with occasional blizzards, ret there are seldom deep or long-lying snows and the abundance of grass renders it easy for the flocks to find subsistence. The grasses on these plains seem not so fattening as upon the mountains of Utah and Idaho, but are more abundant than those of regions to the southward and produce a 
fine class of sheep. In this region are found the larger types of Merinos, with often an infusion of Cotswold or Lincoln or Leicester blood, while mutton-bred rams of all types are used to produce market lambs. Sheep do not permanently injure the grasses of this region and indeed when grazed with judgment, not to overstock, the range is often benefited. In fact, some progressive ranchmen, make it a practice to pasture cattle and sheep together and find that both thrive.

\section{PARASITIC INFECTION OF THE RANGES.}

There is sometimes in this region, particularly in the Dakotas, sufficient humidity to make it possible for internal parasites to propagate and diffuse themselves through the flocks. Grievous losses from stomach worms are reported during bad seasons and tape worms have worked havoc over much of the region.

These losses, however, are far less serious than occur in the states east of the Missouri river.

\section{HAPPI FUTURE OF THE REGION.}

This whole region is destined to be, the author believes, one vast pastoral expanse, dotted with sheep herds, and given over very nearly, to the exclusion of other animals, to the sheep. It is the one part of the United States having abundant grass, admirable climate and soil capable of ornwing almost any breed of sheep in perfection and with little loss from parasitic infection. There is, too, the advantage of an intelligent 


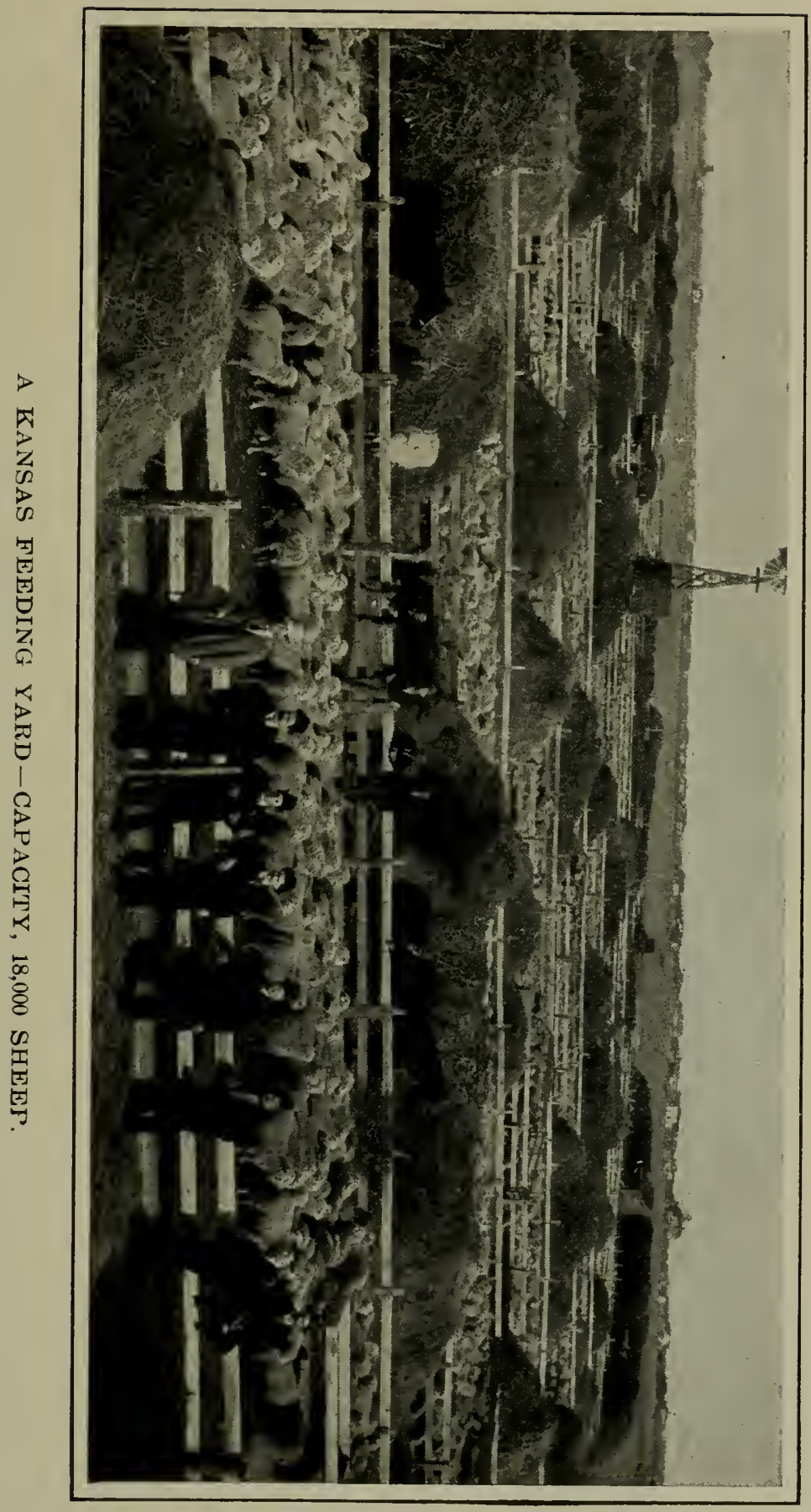



and progressive people embarked in the sheep industry and they have already shown by their work in suppressing scab over large parts of this region what they can and will accomplish.

These plains do not produce as early or as fat lambs as the mountains southwest of them but very superior feeding lambs come from their ranges.

There was once small preparation made for winter feeding in this region. There is today a great deal of hay being put up, both of native and alfalfa sorts. When snow is deep "snow plows" are used, which make bare strips along which the flocks feed. Sometimes corn is fed scattered on the ground. In some parts of this country the summer and winter ranges are distinct, the flocks climbing into the mountains during the heated season and relieving the range of their presence; in other parts the mountains are too remote and the sheep use near by parts of the range for both summer and winter grazing.

Except on farms in the East there is no other part of the United States where much increase in numbers of sheep kept can be made. Here double the numbers now kept, may be and some day doubtless will be kept when the cattle men turn sheep breeders.

MANAGEMENT OF THE RANGE RAMS.

The "buck herd" is a necessary institution upon the range, and often a troublesome proposition it is. There are usually kept about 30 rams to the thousand ewes, though some grow- 
er's use a larger number. Various methods are adopted to keep these rams between breeding seasons. They are sometimes pastured in a fenced pasture and corralled at night to keep them from coyotes. Sometimes they are herded where they are enough of them on a ranch to make a herd and he must indeed be an active and careful herder who will lose none of them, since as fall days come on their instinct leads them to roam in search of females.

Often several ranches will combine their forces and put all the rams together in one herd. And others will allow them to run with the ewes during winter and spring, separating them in summer when there might be danger of too early matings.

Sometimes it is possible to put the rams in a wether herd, though wether bands are not nearly so common as they once were and many ranchers keep none at all, selling off all wether lambs or at most keeping them only till yearlings past.

\section{WHERE THE RAMS COME FROM.}

The source of supply of range rams is principally from large growers of rams situated in various parts of the range country and in the valleys of California and Utah. Eastern Oregon produces thousands of magnificent rams mainly of Merino blood, approaching the Rambouillet type or purely of that blood. California sends many high-class Merino rams to the ranges. Utah and Idaho grow Merino and Cotswold rams by thousands with lesser num- 
bers of other mutton breeds. Wyoming grows Merinos, Cotswolds, Leicesters and Hampshires.

Range-bred rams are most serviceable on the range, having learned how to live there and being more muscular and hardy than Eastern farm-grown sheep. There is, however, a steady stream of the best bred sires from Eastern stud flocks going to reinforce the blood of the mountain stud flocks. The day seems past when large numbers of Eastern farm-grown rams will be used on common range herds since the Western rams are in fairly abundant supply and are more efficient.

\section{THE BREEDING SEASON.}

On the range rams are turned in usually to bring the lambs in late May or June. It is disastrous to lamb down before the herd is settled on good grass and where it may remain for some weeks with little driving. There is not the objection to late lambing on the range that there is on the farm, since the danger of parasitic infection is escaped in the range flock. This is principally from two causes; first, that the soil is usually too dry to permit the germs to develop upon it, and second that the sheep are moved often and seldom return to graze over the same ground before an interval of weeks, months or a year.

\section{VIGOR OF EWES AND LAMBS.}

It is astonishing to see how little difficulty range ewes have in passing through the perils 
of lambbirth. There seems seldom a case of wrong presentation and often not one ewe is lost from a thousand at lambing time.

Then the lambs seem endowed with remarkable vigor at birth and not one of a thousand but will get up and find its mother's maternal fount without aid from the shepherd. Indeed this is fortumate, seeing that he is generally remote from yards or fences, and to catch a range ewe is commonly a work of some difficulty.

It is a lesson to the Easter'n farmer to see the remarkable viability and vigor of these rangebor'n lambs, being an illustration of Nature's way of management to promote vigor and reproduction.

THE BUSY SHEPHERD AT LAMBING TIME.

A good shepherd will, however, be busy at lambing time, for there are many little things to occupy his attention then. One of the most essential is to observe the ewes with spoiled udders and those having imperfect udders, made so perhaps by careless shearer's who cut off the ends of the teats. These lose their lambs and should be caught, examined and marked so plainly that they can never escape the eyes of the master, when next the flock passes the assorting chute.

THE COYOTE.

Then there is the coyote pest. The coyote is a small wolf, not much larger than a big fox, but having a voracious appetite for lambs. To combat coyotes a number of methods are used, 
and all fail if persisted in, since the coyote is one of the most cumning beasts of prey in the world. Strychnine placed in carcasses found dead kill a good many, but some coyotes learn to avoid strychnine. The watchful shepherd gets a chance to shoot one now and then. Occasionally a coyote may be trapped. And greyhounds, or rather special hounds bred for the purpose, having the conformation of the

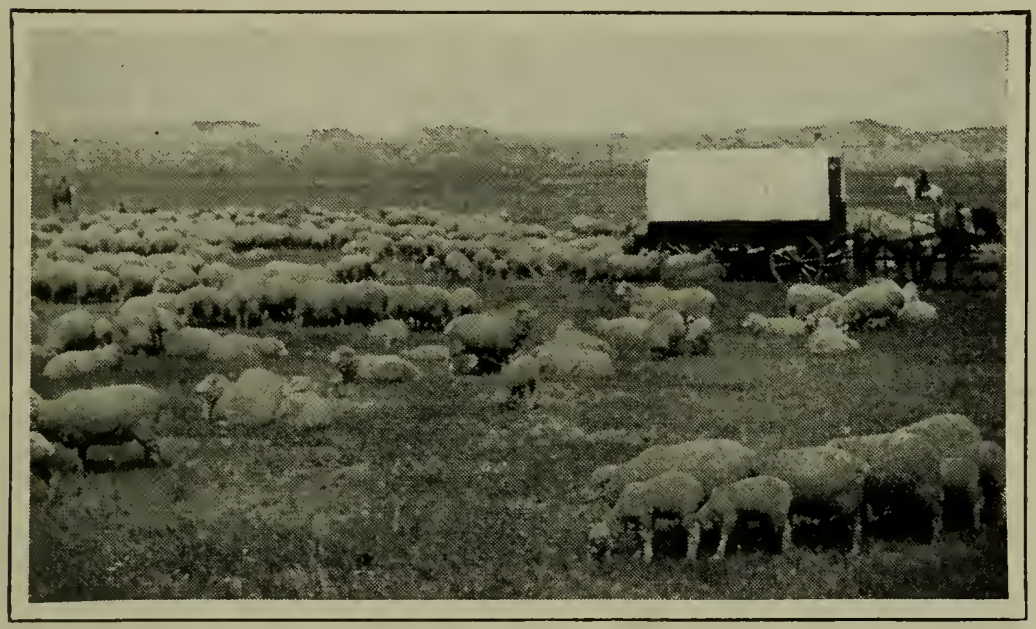

A SHEEP WAGON ON THE RANGE

greyhounds with more size and better fighters, catch some of them.

At lambing time, however, coyotes assemble, scenting a feast. Then the shepherd can not avoid letting his flock spread over quite an area of range since to crowd the ewes close would be sure to make many orphan lambs. It helps to build fires about at various points, as though there were numerous camp fires, and the wary 
beasts scenting danger, keep their distance. To hang out lanterns is a good practice, also. To patrol the flock almost ceaselessly with rifle in hand, firing it now and then is the method most effective, and this is usually adopted by careful shepherds. It is necessary at this time to have help, and two or three men may, if available, keep themselves usefully employed about the lambing flock.

\section{"TRIMMING" THE LAMBS.}

Lambing lasts usually only a week or two on the range, since the rams are not put in till late and the ewes soon come in heat and conceive.

After the lambs have become strong they are earmarked, docked (unless they are to go to market, in which case their tails are sometimes left long), and castrated.

They grow very rapidly if well born on good range. The shepherd has now some compensation for his pains and anxieties. His duties are comparatively light, he has time to keep a neat camp, to hunt a little for grouse or deer, and the flock itself is a source of great pleasure, if he is more than an indifferent hireling. In the evenings when the ewes have assembled, perhaps on the slope of some ravine, the lambs will disengage themselves from the flock and withdrawing a little way will race up and down in mobs, a fuzzy flood, undulating over the ground. Again some belligerents will square off and fight mock fights, butting by twos and threes until one decides that too rough a sport. Again there will be a game of leap frog, or "fol- 
low your leader,', and strings of lambs will race up over banks and rocks and jump stifflegged down the other side.

After a time some old ewe, feeling a pressure within her udder, will disengage herself from the rest and coming to the open will call anxiously for her lamb. As though a miracle some lamb will stop, listen, cease to play and an-

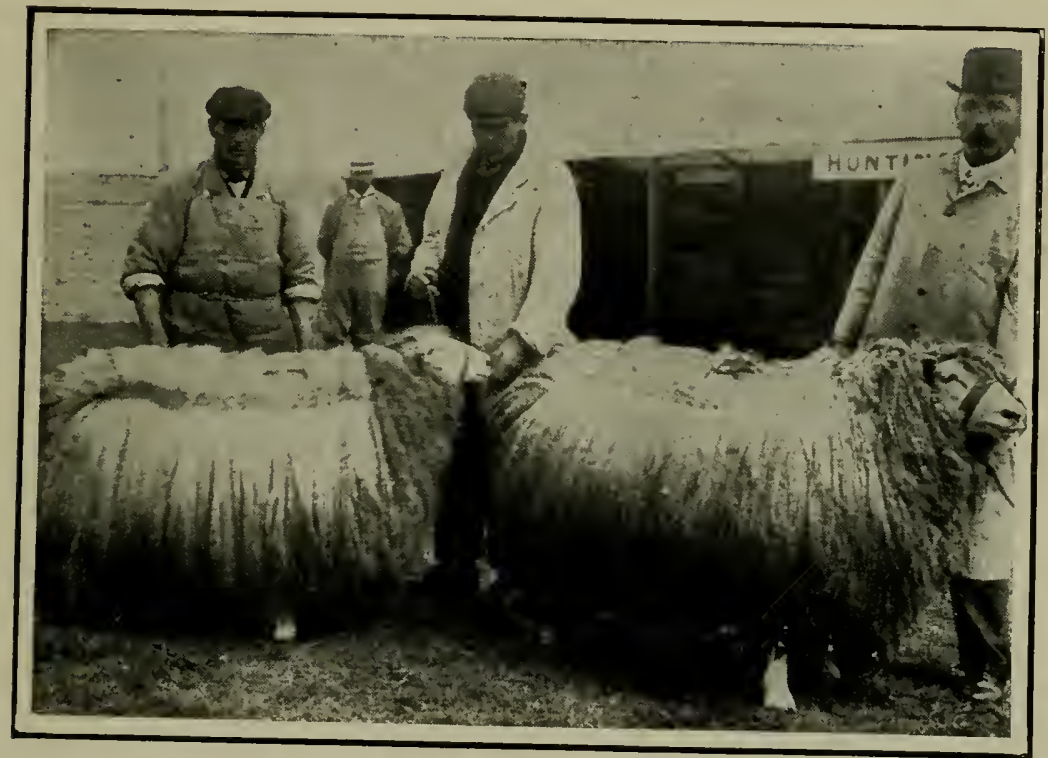

LINCOLN SHEARLINGS.

swering with a bleat, will come scampering across the ravine to her to get his evening meal.

Curiously enough the ewe, though she has seen him a thousand times, refuses to believe that he is her rightful offspring until she has applied her infallible test, her nose. Scent tells her it is her own darling child, and she tranquilly allows him to milk her dry. 
SHEARING ON THE RANGE.

Shearing on the ranges occurs at different seasons, according to the conditions and character of the country. Usually in southern ranges it is before lambing; at railway stations where the wool is readily shipped away. If on the other hand, the ewes are shorn upon their summer range, they may be shorn after lambing.

The shearers are roving groups of men, as needs must be, possessed of iron muscles and great deftness of hand. A good shearer will average 100) sheep a day, for which he gets from seven to twelve cents per head. Nor must Eastern shearers console themselves that these men do exceptionally rough or careless work; they shear on the average, quite as well as the common shearers of the Eastern states. Nor are their sheep as easily shorn as the general run of farm sheep in the East. Many a careful man has laid the foundation of his fortune by shearing sheep on Western ranges. An old friend of the writer, now known and honored throughout all that mountain region and one of the largest sheep owners, began ranch life as a shearer on California ranges. He now owns probably 50,000 sheep of his own. There are now a good many plants where machine shears are in operation and their number is increasing; nevertheless there are many situations where the old hand shear's will continue to be used.

DIPPING.

Dipping on the range should be a regular yearly or semi-amnual practice. When it can 
be done it should follow shearing. Another practice is to dip when the lambs are weaned in the fall. 'The dipping is done in a rapid manner by means of very long tanks or swimming vats, through which the sheep are crowded in rapid succession. A furnace adjacent, with boiler's, heats and cooks the dip used. Several thousand sheep are dipped in a day, according to the size of the plant. The dip most used is

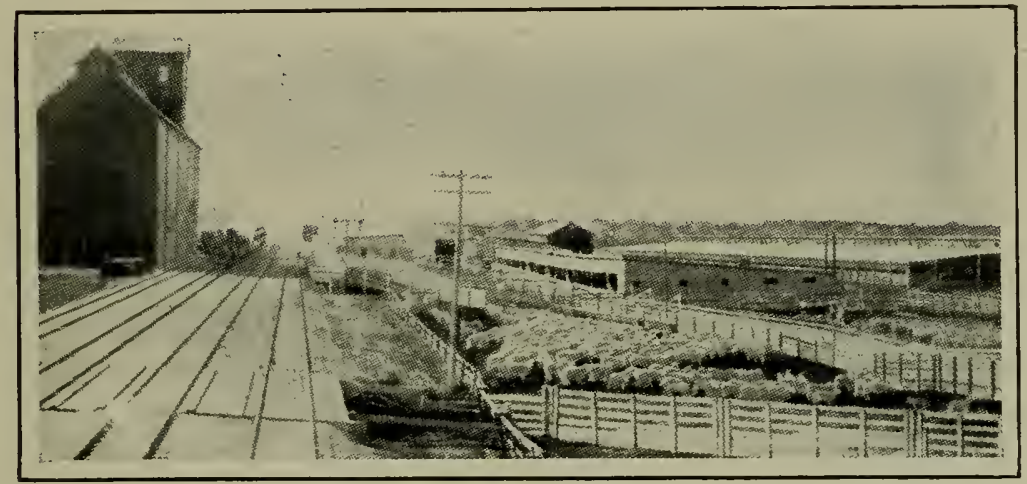

AN ILLINOIS FEEDING AND SHIPPING YARD.

lime and sulphur, which is certainly when rightly compounded an efficient scab destroyer.

The writer when engaged in sheep ranching on the hills and mesas of Utah did not use this dip, since it is injurious to the fleece and seemed not to eradicate the disease, but used instead one of the dips prepared from coal tar, using it strong and hot, and entirely eradicated scab from his range, so that it did not again reappear during his occupancy of it. There is no doubt that scab can be entirely banished from the ranges if men can be educated to it, and have 
instilled within them a living conscience that will lead them to do their plain duty toward themselves, their flocks and their neighbors. The obstacle to complete scab eradication is the ignorance and criminal indifference of the lower class of sheep owners and the abettors of these criminals are often the state inspectors, who very often make of inspection a farce and give to their friends, or to other's for a consideration, clean bills of health when scab is really widespread. To give them the benefit of a doubt, however, these inspector's very often would not be able to recognize a case of scab were they to see it except in the last stages. There is growing, however, a healthy sentiment, and sooner or later the neighboring ranchmen will themselves take it upon them to see that scab is eradicated from their district and compel the indifferent to clean their flocks in self-defense. That done a great and unnecessary expense will be saved, since it will not be necessary to dip so often, only ticks being to combat, and a heavy clond of apprehension will be removed from the sheep owner's mind and the shepherd's as well.

\section{TIIE MALIGNED " SHEEP HERDER."}

There is in the minds of the public a deepseated prejudice against the range shepherd, the "sheep herder," and he is often regarded as being an ignorant, lazy, and generally degraded individual. There is doubtless here and there a man of that sort engaged in herding sheep, but in the main the herders are men of 
character and intelligence. Their work developes within them quite different characteristics from those developed in the man who herds cattle, the "vaqueros" who do their work on horseback.

The shepherds acquire patience, thought and faithfulness. They develop endurance and stoicism. Lacking the dash of the cowboys, they have greater capacity for enduring discomfort and fatigue.

There are every year wonderful things done on the sheep ranges by these faithful herders. Storms come and blizzards blow and sometimes there is no shelter. 'Then the sheep can not be restrained but drift aimlessly before the blast. Then the herders forsaking their tents and the comfort and shelter to be found therein follow the sheep, striving to keep them together and if possible to lead them at last to a safe shelter, perhaps among pines or behind sheltering cliff's and hills.

Oftentimes these storms endure for several days and the shepherd may find no refuge nor help until at last he is overcome with weariness and cold and lies down in the snow for rest. Here he is found, sometimes yet alive and more often frozen to death. There is hardly a winter that there are not a number of herders lost in storms and there have been single storms that counted their dead by scores. The writer knows one old man, a fine herder he is, who has been found buried in a snow drift beside his flock, miles from the camp, so frozen that he lost all the fingers of both hands, only one 
thumb remaining. This old man, after the terrible experience, calmly resumed his occupation, and even managed to live alone and make camp in his crippled condition.

Men of foreign birth often make excellent herders for the range country. Germans excel, Portuguese are reputed good herders, Andalusians have a reputation in parts of California, a Chinaman has been known to become a skilled shepherd and Mexicans have their virtues, among them a dog-like fidelity, though they are not reputed so daring and resolute in time of stress as men of Northern climes. And now and then a lad of American stock excels. Scots are everywhere found among them, and everywhere in the lead, having a heritage of sheepkeeping ancestry and tradition.

\section{UPS AND DOWNS OF THE BUSINESS.}

It is to be regretted that the sheep industry has such remarkable ups and downs. There will be a series of years when flocks on the ranges make their owners very large profits. As, for instance, if a thousand ewes cost the owner $\$ 3,000$ and thirty rams will cost maybe $\$ 300$ more. The expense of keeping them will vary greatly, but may be as low as 60 to 75 cents per head, or, say, $\$ 772.50$. It has been known that the thousand ewes would drop and rear, a thousand lambs, but cutting this down to 850 , they sometimes sell for as much as $\$ 3$ each on the range, or $\$ 2,550$. Then the fleeces have sold recently for more than a dollar per head, or 
$\$ 1,030$ more, leaving a paper profit of $\$ 2,807.50$ on an investment of but $\$ 3,000$.

However, as there will needs be some ewes die and rams to be replenished, we can take off the $\$ 807.50$ to put with the herd and still leave a nice dividend.

On the other hand, when times are good and sheep prices high the wary operators are willing to sell, and men with moderate or small amounts of capital buy, giving mortgages on all they possess for security. Thereafter (and oft-times soon) things happen! Wool declines in price, lambs go begging, hard seasons come and the men find themselves often involved in absolute ruin. It is related during the last slump in sheep values, about 1894 , in Texas a rancher started to market with a train load of sheep. He got drunk in Kansas City and the sheep went on without him, sold, but not for enough to pay the freight. He therefore received a letter from his commission firm asking him to remit for the freight, and they in turn received a telegram from him saying, "I have no money ; am sending on more sheep.",

THE HOPEFUL OUTLOOK.

The writer believes, however, that the days of ruinous prices for sheep are over. The capacity of our country to consume sheep has grown very enormously. The mutton-eating habit, once formed, is retained. Mutton is indeed an economical meat to buy, since in chops one can buy small amounts more easily than in beef 
steaks; thus the high price does not so much count. And mutton, especially lamb mutton, is consumed by the well-to-do,- a steadily increasing class in our country. It is hard to believe that there will ever again be such a Waterloo at

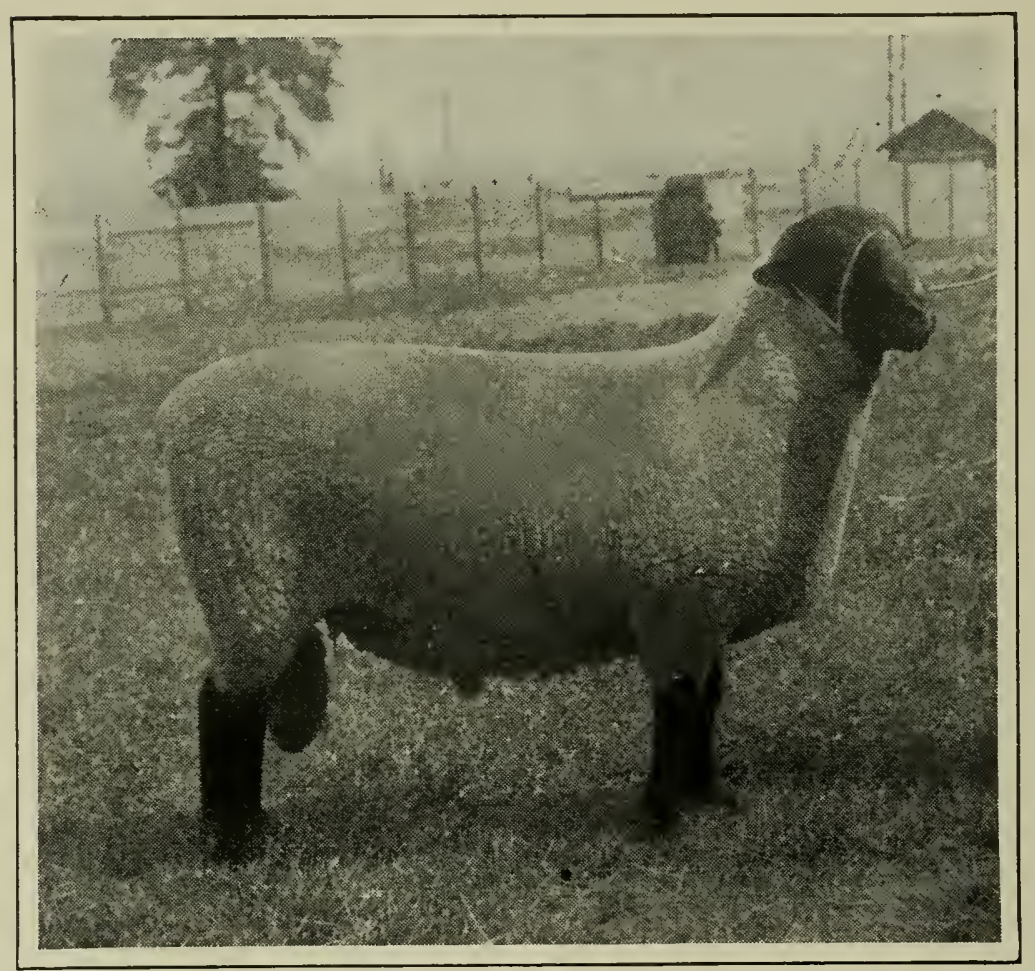

SUFFOLK RAM.

the last decade of the Nineteenth Century brought. And yet the writer wishes to prevent his friends from rushing heedlessly to buy when prices are the highest, and to caution them from following the example of the Texan and 
giving their flocks away merely because they are temporarily depressed.

\section{A WORK TO BE DONE.}

There is a great work remaining to be done on our ranges, - that is to build up the quality of the flocks till they approach in excellence the quality of the flocks of New Zealand and Argentina. The writer once in Deptford Market, where the live cattle and sheep sent to London from foreign ports are slaughtered, was shocked to see how much better were the strangers' sheep than those of his brethren. Needless to say that the good sheep brought much the better prices.

To thus upbuild our range flocks needs a steady inflow of the best rams, mainly of Rambouillet and the larger, smoother Delaine type, and the crossing of their produce with rams of Lincoln, Cotswold and Leicester blood.

Such cross-breeding needs, to be a success, great study and attention and of course with finer animals comes always need for better feed and care, for provision of forage for winter and cessation of long and fruitless journeyings. These things will come, the great plains and grassy mesas and green forested mountains will soon be covered with flocks of far better sheep than they hold today, and by some sort of peaceable division of the ranges each rancher will know where he may graze and where he may save grass with sure expectation of feeding it himself in time of need. 


\section{SHEEP ADVANCE-CATTLE RETREAT.}

It is the opinion of the writer that the cattle will steadily retreat before the peaceable advance of the sheep, since sheep are best fitted for this region and bring far more profit. There will always be room, however, for some cattle and they will be found to thrive alongside the sheep, when the day of intelligent grazing and range management has been reached.

WINTEK FEEDING OF SHEEP AND LAMBS.

The writer does not think it worth while to devote much space to describing the best methods of feeding native lambs in winter, for the reason that natives (those born on Eastern farms) ought to be fat and sold before winter has set in. If they are not fat it may verylikely be because they are infected with some depressing parasite, such as stomach worm or nodular disease, and in that case are hardly worth fattening at all. In his own practice he has abandoned feeding native lambs entirely since his own lambs, born upon the farms, are fat and sold before July and those he can buy give him almost certain trouble.

It may be said, however that if one is to feed native lambs he should select them if possible with an eye to getting the good ones, those in health. These are easily discovered. They show their health by the vigor of their action. the quickness of their movements, the brightness of their eyes and if examined closely the pinkness of their skins. Those that are droop- 


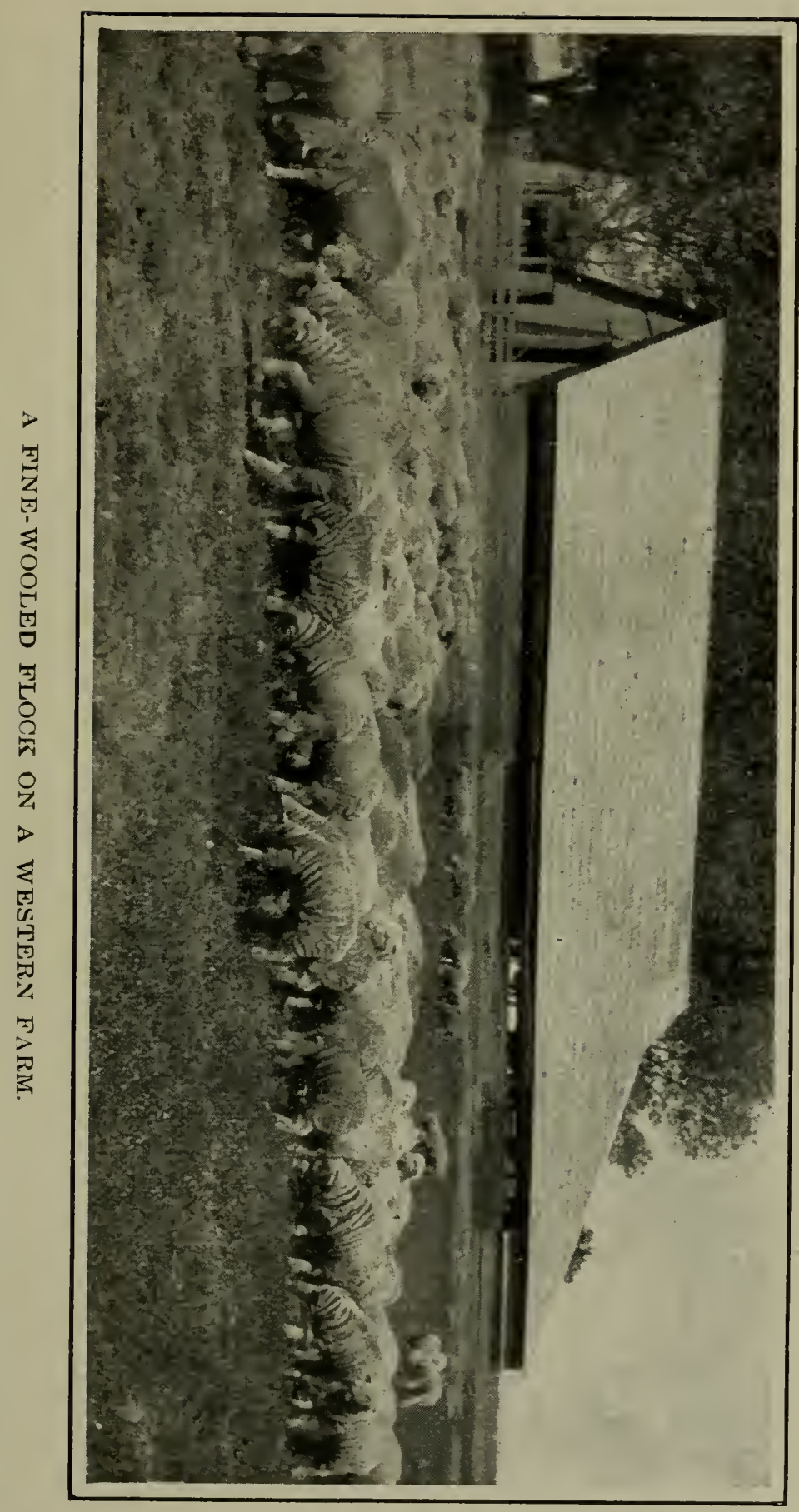



ing or that show white chalky skins, signs of diarrhoea and have dead-looking fleeces are surely infected with worms and if they can not be discarded they should be treated before being put on feed.

It is not well to turn feeding lambs out on pasture when they are brought home. They will gain little on pasture in the fall, unless it be some special sowed crop such as rape or vetches, and to turn the lambs on the grass pastures usually results in gnawing the grass to the ground without putting on any gain as compensation. It is therefore best to put them directly into the feed lot and to begin feeding them on dry hay, or other forage.

\section{NECESSITY FOR DIPPING.}

Earlier in this book directions are given for dipping and the reasons why. We will here repeat and emphasize the fact that all sheep that have been shipped on railway cars or penned in railway yards are very apt to be infected with germs of scab. If they have no scab germs they almost surely have ticks on them. Ticks will fatten in the same shed with sheep but the sheep will suffer. Ticks find slow sale in the market place. Scab, if it breaks out during the feeding season, is ruinous and will entail great loss unless promptly suppressed. The longer dipping is delayed the more costly it is because of the greater amount of material required, because of the greater degree of exposure when the weather is colder, and because the animal after being on feed suffers a greater shock and 
has a worse set-back than when dipped on its arrival at the feed yard.

I ambs that are sent out from the larger center's of distribution, such as Chicago, Omaha and Kansas City, are dipped under Federal supervision before they leave the yards. This dipping should preclude the necessity of further dipping at home unless in the case of very well advanced cases of scab. Such instances of diseased sheep are much less numerous than they once were, thanks to a rather determined scab campaign by flock-owners on the ranges. The dipping at the Chicago yards has for several years been so thorough that the writer has ceased to again dip the lambs received from that place. He feels, however, that he is running considerable risk by this neglect, since it is only a question of time when carelessness or "graft" will send out again strings of imperfectly dipped lambs from these very yards. This has, at least, been the history of the past. One winter some years ago the writer trusting to the dipping there received had the distressing experience of having to dip every sheep upon the farm in midwinter.

It is safer then not to rely upon the dipping at the yards, but to dip carefully upon arrival, or as soon thereafter as the lambs have rested and recovered their strength. Until that time if the weather be good it is wise to turn the sheep into pasture, where they may find water and grass and rest sufficient to recruit them. Then, as soon as rested, they should be dipped 
and put at once into their permanent quarters, if they are to be fed in yards or sheds.

\section{SELECTION OF FEEDERS.}

A visit to one of our great stock yards is a most interesting experience. There are seen there such a multitude of sheep of almost every sort and description. There are great bands of fat Western wethers, noble sheep, some of them of an astonishing uniformity in size and character. They are "strong almost as horses," used all their lievs to roaming over the plains and mountains. These may go for export, or to the killers. They are too fat to feed and would cost too much. And yet they are not so fat as the sheep that come in winter and spring from the feed lots. They are just right to give the most profit to the killers, with enough fat and little waste.

Beside them will be a band of thinner wethel:s, perhaps from a dried-up range, of fairly good quality. They, too, will go to the killers, though they are almost thin enough to sell at a farmer's price. The next pen may show some sdeal feeder's, big and strong and active, yet in thin flesh. Probably it did not rain on their range, or they traveled too far. The killers pass them by and the feeder gets them at a cent or more off.

In the next pen will be seen a different type altogether, a band of wild, scarred, thin, sharpbacked, weazened sheep, looking as though all the plagues of Egypt had struck them. They are the product of an ignorant and stingy own- 
er, a careless and unprofitable shepherd and a starved and overpastured range, together with a dearth of rain and snow. No one wants them and they sel! very low indeed. Sometimes they are great bargains and if carefully nursed for a few months will lay on flesh fairly well and being bought so cheaply will reward well their feeder. There is, however, the disadvantage of having your yards filled with stuff of which you are ashamed till near the last of the feeding season. They are more likely to make money for their feeder than the good feeder's because they are bought so cheaply and weigh so little.

However, if there is not at home plenty of good clover or alfalfa hay, or if the feeder is not willing to buy for them wheat bran and a trifle of oilmeal, if they must be fattened on corn and cornstalks mainly it is doubtful if they are of the class that he should buy. Emaciation calls for foods rich in portein. With plenty of earlycut alfalfa hay in the mow these thin sheep may bring profit. They are of no value for a short feed. They require time to first restore their strength and afterward to rebuild, or perhaps build their flesh and afterward to lay on fat.

Unless one can buy at a low price per pound it is unwise to buy the emaciated ones, seeing that his profit comes largely from a hoped-for advance on the purchase cost and it costs money to build flesh in the feed lot.

There is, however, another range of conditions to be considered when selecting our feeders. That is the breeding of the sheep. Here is a pen of very heavily fleeced wethers, or 


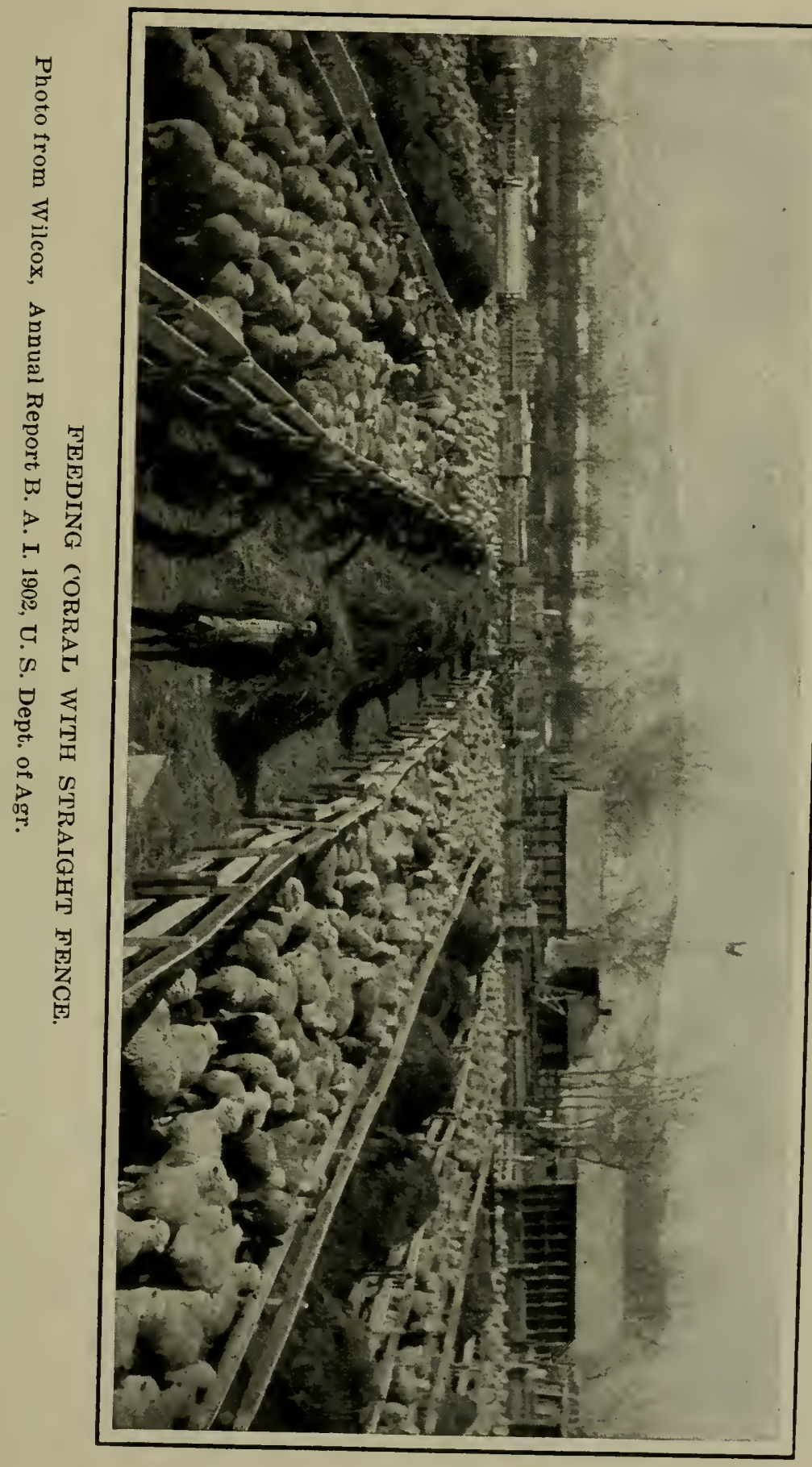



lambs. They will shear very heavy, but they are not of the best form. They have thin necks and drooping sharp shoulders and a look of meekness and depression. Shall we take them? In the next pen is a lot with evidence of mutton blood on the Merino. They are lighter fleeced, but stronger. As a rule the very heavily Heeced sheep are not the best money-makers. 'They will not eat so well nor make so good gains. Nature specializes; the food goes to flesh or it goes to fleece and oil in the wool. And after a time thrown together, probably into a load of good feeders. It is only the exceedingly heavy fleece that is to be avoided.

Now visit the lamb pens. The wethers have run very even and have required little assorting. The lambs are even also, but there is with them a few culls so that the buyer for the great packers usually reserves the right to discard 10 , 20,30 , or maybe more of each lot. These are after a time thrown together probably into a load of feeders. The lambs are in character about what the wethers were, though they have suffered more in transit and are not so strong. Again we see the killer's bidding high for the tops. Then goes up a sigh as you relinquish them, and you look on down the line. Ah! Here are the beauties! They are from Merino mothers, evidently, and their sires were Shropshires, or maybe Lincolns or Cotswolds and they are small and in rather thin flesh, so there is a chance. They have been born late and their tops have been selected and sold, these younger ones remaining. 
If we get them we have done well. They will grow and fatten admirably and be our pride and joy all through the feeding season. When fat they will command the top price. If we buy them we will take 350 (which fills a car) or maybe 700 or 1,050 , and we may need to buy some smaller lots to make the number come out even.

But hold! Those lambs were after all priced pretty high, and here are some lively little fellows, not so well bred, quite, but yet giving evidence of good blood. They are very late and small, pretty thin, too, weighing less than 50 pounds. What of them? It depends upon what is stored at home in the barn. If there is abundance of good alfalfa, if there are silage and and perhaps roots, and loving care and generous shelter and long time, take them! 'They are the best. But if the feeding season must be short, if there is little clover or alfalfa, take the other lot.

And here is yet another sort. They must have come from a terrible range where grief has been their constant portion. They are miserably thin and weak and were ill bred at the beginning. Their one redeeming feature is that they weigh little and will be sold for a very small price per pound. Shall we venture to buy them? That also depends upon the furnishings at home. Many of them may die before they gain enough strength to enable them to go on and gain. They will require a long feeding period. But when they are fat they will sell for nearly as much as the best bred lambs 
in the market. There is that peculiar side to the lamb trade: the light lambs of part Mexican type when rightly fed sell well. So if we have the feed, the kindness and comforts at home, we may venture to take even these weaklings. But let us beware of them if we propose to "rough them" or to try to hasten them along by a short period of heavy feeding.

Here is yet another opportunity. In these smaller pens are a lot of thin Natives, from some near-by state. They are big enough but their lack-luster eyes and sunken wool and general air of discouragement speak surely of an internal revenue department held under the rule of predatory parasite worms. If these lambs had been in health they would have been fat, in nine cases out of ten, and the killer's would have taken them in. Avoid them unless you understand treating them and eradicating the worms. Thin Western lambs do not often have these parasites because on their drier ranges the diseases do not lodge nor spread. And yet lambs from some of the more Eastern ranges, in the Dakotas, Nebraska and occasionally from Montana, come now and then infected. Before you buy these thin lambs look at their skins. If they are chalky pass them by.

Here are ewes. This band of old ewes, in thin flesh, shows evidences of fairly good breeding. They have a motherly look too. We find that we can buy them cheaply. What can we do with them?

Let us look first at their teeth. Ah, I thought so! A large number of them have lost their front 
teeth. This means two or three things. It accounts for their being sent from range to market. They have been culled out because they no longer could subsist well on the tough grasses and herbage of the range. It accounts mainly for their emaciation And it means to you, "Am I in position to take good care of these old ewes?", These ewes may not be too old to make a good recovery under favorable conditions; they may even drop a strong crop of lambs and nourish them well, but they must eat more costly food than ewes that have their teeth.

They ought to have bran, oats, shelled corn and early-cut, tender hay. But they are for sale, and at a low price. If it is early enough so that we can breed them to good rams we may do this ; take them home and at once mate them with the best rams of Shropshire, Southdown, Hampshire, Dorset or whatever we fancy that we can get and then carry them along well, not forcing too much till after the lambs are born, and after that with judgment and discretion pouring into them all the good nourishing stuff that we can get them to consume. It will astonish us how those lambs will grow, and the beauty of them coming from these skinny old ewes but they may be soon sent off fat to market and the mothers will have gained all the time in flesh and in about two months' more feeding will be ready to go after their lambs. This is good practice and only requires the right combination of careful handling, with skill in feeding, warm, well ventilated barns and an assortment 
of feeds with wise generosity in carrying it out to make the thing pay. In fact, this thing has been done. 100 ewes have been bought in Chicago for $\$ 175$. They have dropped and raised 90 lambs that sold at about 10 to 14 weeks' of age for over $\$ 5.00$ each. The ewes sheared, under this good care, above 7 pounds each and the wool sold for 25 c. Then the ewes finally fattened and weighed 112 lbs., selling for $5 \mathrm{c}$ per pound. Thus the erre that cost $\$ 1.75$ in Chicago sold, with her wool and lamb, for $\$ 11.85$ in late May. This was an exceptionally favorable result, however achieved by an assemblage of favoring conditions of low first cost, fairly good quality, good sires, wise and generous treatment and a booming spring market. Let the indifferent shepherd, or the one having ear corn and timothy hay, beware of these broken-mouthed ewes; they will undo him every time.

There is danger that these ewes may part of them be already with lamb to some inferior range ram. These lambs will not usually fatten off at an early age and may materially affect the result.

Let us digress here to consider for a moment a proposition having in it great possibilities of profit for the feeder and offering to the rancher a ready means of disposing of his aging ewe stuff without too much sacrifice. The rancher may cull out his aged ewes before they have reached too decrepit a condition, discarding any that have spoiled udders or defective teats, and putting them on the best and tenderest grass he can find. Put with them good blocky mutton 
rams as early as possible in summer. He ought to get a Down or Dorset ram for this purpose, since the long-wools do not get lambs fattening best at a very early age.

Then he can sell the ewes, bred, to men who make a business of fattening winter lambs, and get a great deal more for them than it has cost him to give them this treatment. The writer several years ago called the attention of sheep growers and feeders to the possibilities of this

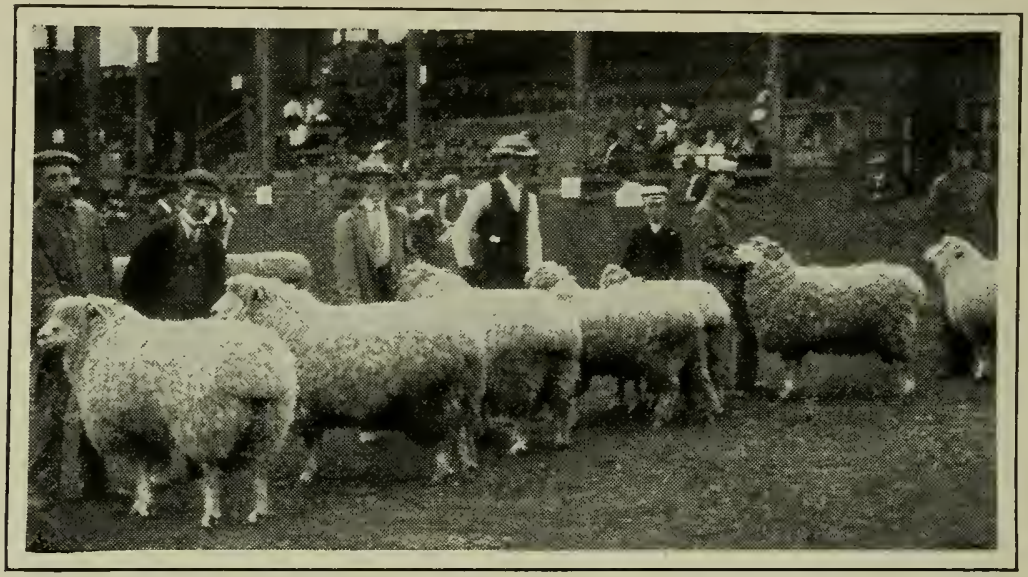

A SHOW OF COTSWOLDS.

practice and it has already been begun in a small way with the probability that the practice will become more common as the advantage becomes known, and especially as Western sheep ranching narrows down to a state of settled practice of good methods

The age when a ewe should be discarded. varies considerably with the breed and also with the district where she is kept and the manner 
of keeping. In England among the Dorset breeder's it is the custom to take three or four crops of lambs from a Dorset ram, then to breed them to a Down (Hampshire, Shropshire or Sussex), and sell them in lamb to go away to men who make it a practice to buy these ewes, grow from them one or two crops of lambs and send them fat to market. In America it can hardly be said that there is any established system anywhere, and the more usual method is simply to continue to use the ewe so long as her teeth are good, disposing of her then for what she will bring. There is something to be said for this practice, though undoubtedly when we have settled down to a good and regular system of management, when we have formed a habit of good management, we will turn off our ewes young enough so that they may be finished easily into prime mutton and will not have become "shelly." The number of lambs that can be taken from a ewe varies somewhat with the breed. Those that mature quickly the sooner lose their usefulness. Merinos taking long time to mature are sometimes productive for 16 years or more. Downs and Dorsets are usually past their usefulness at twelve years. In general it is good practice to discard ewes upon farms at about the age of six to eight vears. To return to our yards: there is a vastness about it and a bewilderment that appalls the man fresh from tranquil fields where a flock of 500 sheep seems large. On some single days there will be received at the big markets as many as 25,000, or even more, and in a single 
brief forenoon most of them will be sold and many of them dispersed, some to the killers and some to the dipping vat and on cars again to go out to country feeder's It is a confusing place to the countryman and he is wise to choose some skilled commission man to go with him and make his purchases, helping, too, in making selections.

It is not always wise for the feeder to go in person to the market, though he should make it a point to be there once or twice a year to study types and results of other men if possible

The advantage in leaving the purchase altogether to an lionest and capable commission man (there are such in most markets) is that the commission man may take advantage of heavy runs and depressed markets to secure for the feeder his supplies at the lowest price. Naturally when the man goes himself to the market place he desires to make his purchase and get away whether conditions seem to him just right or not. His impatience may therefore cost him dearly.

It is a good plan to set a price that you are willing to pay for the class of sheep that you decide to feed and carefully describing your wishes state the case to your commission man, leaving the order with him to be filled when he can. It may happen that you are too low and your bid may need to be raised, or the stuff may cost you less than you have expected to pay.

The feeder may if he desires go in person to the ranges and make his selections there, bringing his purchases directly home. Thus he will 
get the best and get them home fresher than did they lie around in stock yards awaiting purchasers. The practical disadvantage of this, however, is that on the range the buyer must pay the rancher's price; if the sheep go on to market he sets the price himself.

It is especially desirable in buying on the range that the purchaser should take care to weigh at least a portion of the stuff and make due allowance for shrinkage in shipment, else he may buy very dearly without being aware. In advising the feeder to beware of thin $\mathrm{Na}$ tive feeders the writer is aware that he is prejudicing his very subject and aim, the building up of flocks of Natives in all the regions east of the great ranges. It must be remembered, however, that in most of this region food is so abundant, both of grass and grain, that almost any sheep in health will be fat when it goes to the market, and therefore snapped up eagerly by the killers, except those that are parasitic and therefore difficult to make fat. He hopes and believes that the day will come when this condition will be overcome and sheep will be found as healthy on farms as on ranges, but even then they will go fat to market instead of going to swell the supply of feeders.

\section{FEEDING OF LAMBS.}

Let us now take up in detail the work of lamb feeding, having by this time purchased our supply of feeders, or having grown them ourselves. Methods of lamb feeding vary widely according to the district where they are fed. We will consider the several ways in detail. 


\section{CHAPTER IX.}

\section{WESTERN LAMB FEEDING.}

\section{PEA FEEDING IN COLORADO.}

In the San Luis valley of Colorado a very curious method of fattening lambs has within recent years grown to large proportions. This valley lays very high, so high indeed that alfalfa does not thrive as it does elsewhere in the irrigated valleys of the West. But Nature evens up things and here is found the natural home of the field, or Canadian, pea. The soil and climate seem admirably suited to the growth of peas. Indeed it is said that nowhere else in the world do peas thrive so well. The soil is somewhat alkaline, full too of mineral riches, and the abundant irrigation and cool mountain air assure a good growth and a very heavy fruiting. The methods of culture are easy and simple; after being drilled into the soil and irrigated (sometimes with cultivation and sometimes without) they soon cover the ground and need no more attention. The climate is so dry that the crop may stand sometimes without waste until it is consumed. The harvesting is simple in the extreme. Lambs are bought and turned 
in where they remain until the crop is harvested and the lambs are fat. 'There is no need of other' forage than the dried pea vines give, nor of other grain than the peas. Gains on this ration are very large and the quality of mutton produced unexcelled. The growth of this new industry has been very rapid indeed, since practically the first efforts were made in the winter of 1901-1902, when about 3,000 lambs were fed, and it is said that in the winter of 1904-1905 160,000 fat lambs left the San Luis and adjacent valleys of Colorado. It is probable, too, that this is the beginning of the industry, for there are doubtless other valleys in Colorado high enough, cool enough and dry enough to grow peas well, and so of Utah, Idaho and Wyoming.

CANADIAN PEAS FOR LAMB FEEDING.

The Canadian field pea is similar to the common garden pea. It has no relationship to the southern cow pea. The Canadian pea thrives during cool and moist weather, it grows a large vine and sets freely with peas. All animals relish peas which are not only delicious to the taste but very nutritious. Peas are very rich in protein, having in fact about the same composition as milk, minus the water. Peas are easily digested.

Not all regions are adapted to the growth of the field pea. In the corn belt they thrive if they can be sown early enough, but then they must be promptly fed as a soiling crop or else cured into hay. Oats and peas mixed make a first rate soiling crop and have been much used. 
Late sown peas in warm or dry regions have little value. The great pea regions are in Canada, in northern Michigan, Wisconsin and Minnesota. In New England and northern New York, and now, more recently, in the high valleys of the Rocky mountains.

\section{PEAS IN THE SAN LUIS VALLEY.}

The "Sunny San Luis" is a wide and fertile valley about 7,500 feet high in southern Colorado. It has a long, cold but dry and sunny winter, a spring lasting for most of the rest of the year. The nights are always cool in the San Luis. The valley is abundantly irrigated by a peculiar system. The soil is soaked by long continued furrow irrigation till the "sub", or underground water level rises nearly to the surface. Thus, even in a dry climate, there is moisture in abundance for the coolness and moisture loving peas.

The San Luis valley was primarily devoted to wheat growing. Peas were first planted to rebuild the depleted soils. This they did, and incidentally in order to consume some of them and get rid of them sheep were turned in. The sheep thrive astonishingly. When lambs were put on the peas, they grew fat with astonishingly little care or expense. Now lambs feeding on peas is a large business in the San Luis valley each year.

The usual method is to grow the peas by sowing broadcast and letting them mature, turning in the lambs in the fall, sometimes as early as October, sometimes earlier. The lambs 


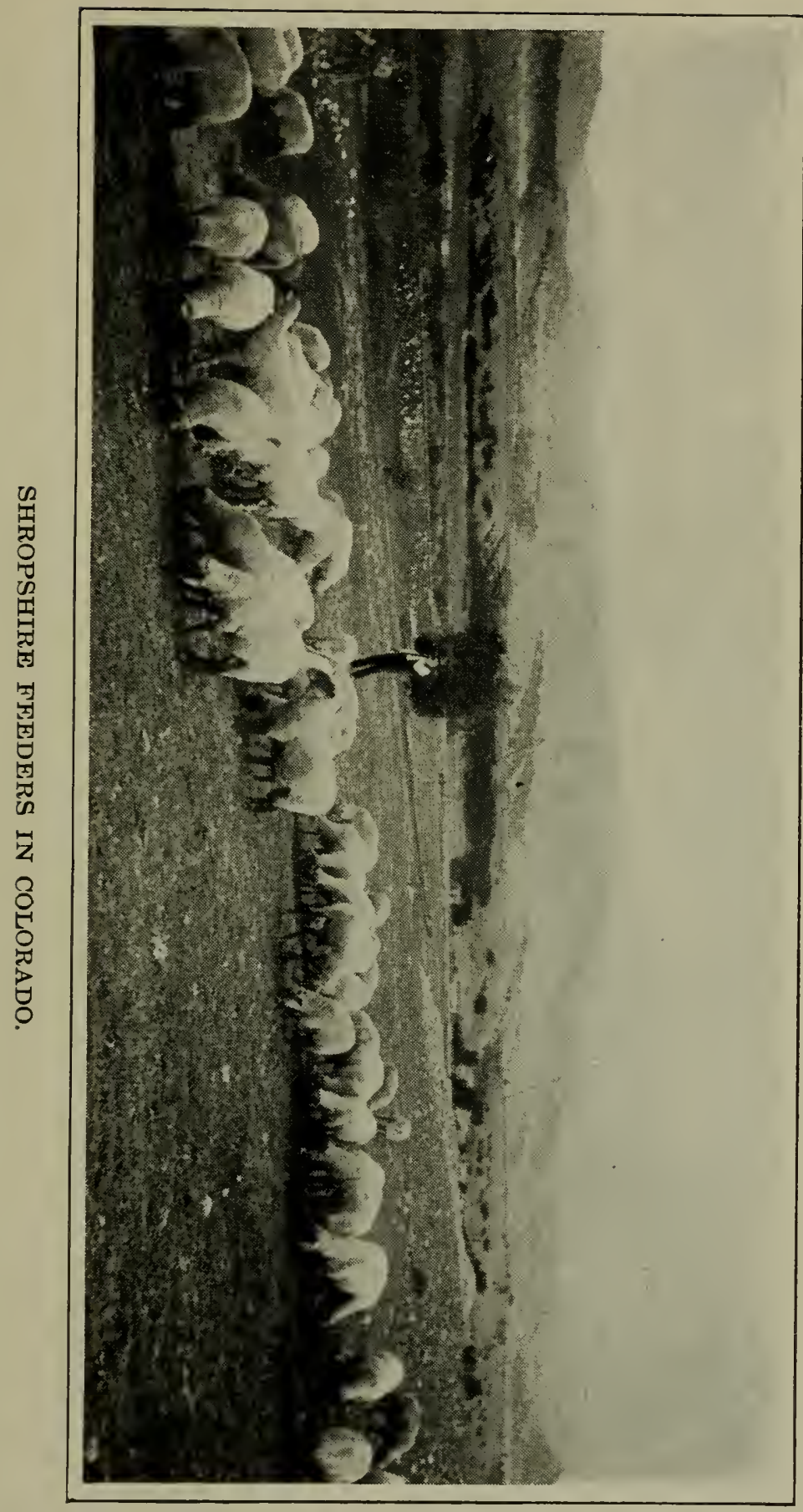



gather the peas from the vines and eat more or less of the forage. The fields are usually fenced and the lambs turned loose, from 500 to 2,000 in a lot. At night they are usually corralled to protect them from coyotes.

When the weather remains dry there is no great waste of peas by feeding in this manner. With snow, however, there is danger that the forage will become greatly damaged and more or less of the peas lost.

It is not an economical way to utilize peas at best because the lambs travel too much in gathering them and by their restlessness fail to put on flesh as ther would were they confined to a small feed-lot. The advantage of feeding the peas where they grow is, however, two-fold. There is saved ail the labor of harvesting them and the manure is scattered as it is made and thus the field is enriched. Where labor is scarce and dear as it often is in Colorado these are important considerations.

There is another way that makes a fair compromise between harvesting and feeding the peas in a yard and letting them lie where they grow, that is to cut them with a mower and cock them up in rather large cocks, then letting the lambs run to them. It would seem that this was a good scheme, especially if the lambs have a shepherd with a dog so that they may be kept from running over the whole field at one time. There would be practically no waste in feeding by this plan, especially as pigs would follow the lambs and pick up what they left uneaten. 
Undoubtedly the greatest number of pounds of mutton could be gotten from an acre of peas by harvesting them and stacking them as alfalfa is stacked, and feeding them in corrals as alfalfa fed lambs are fed. It would no doubt pay also to feed some supplementary grain in troughs, so as to let the lambs consume nearly all of the pea forage and still have grain enough to make the proportion of concentrates to roughness a just one. In this manner about twice as many lambs can be fattened from a field of peas as by the simple process of leaving the peas lie where they grow and the lambs to harvest them at will.

AMIOTN'I OF LAMB MUTTON FROM AN ACRE OF PEAS.

The pea feeding industry is yet in its infancy, and no one knows exactly what can be done with an acre of peas. Undoubtedly the greater number of pea feeders fail to make the most of their opportunities because of poor methods. They let the peas damage by lying in the snow, or they over-stick and have not enough peas to finish their lambs, or they let the lambs run off in travel and lose flesh that should remain on their ribs. Peas gathered and fed in quiet should give about these results.

An acre of peas may yield 30 bushels of shelled peas. Probably that is above the average yield, yet it is not unusual for San Luis peas to exceed that. A bushel of peas weighs $64 \mathrm{lbs}$.

An acre of peas in the San Luis valley may yield $1,800 \mathrm{lbs}$. of shelled peas. 'This is doubt- 
less above the average, but many surpass that rield. Peas are exceedingly digestible when fed whole to lambs so it is probable that 3 , or at most $31 \% \mathrm{lbs}$. of peas would make a pound of gain, if the forage was good and the conditions right. Thus an acre yielding 1,800 lbs. of peas should make from 500 to $600 \mathrm{lbs}$. of mutton.

While there is no doubt that some careful feeders, using some supplementary grain and feeding in corrals, will reach this high mark, yet at present under the easy method of turning the lambs directly upon the peas, not more than 100 to $175 \mathrm{lbs}$. of lamb are secured, and about 100 lbs. of pork from the pigs that follow the lambs. The death loss from feeding peas is said to be exceedingly light. The quality of the mutton so produced is very high. T'he peas also greatly enrich the ground on which they grow. The best method of feeding these peas would seem to include thought to put on them only good lambs and to put them on as early as the peas are nearly mature. There will always be a demand for good pea-fed lambs at a premium and the commoner sorts of lambs should be fed elsewhere. There are other regions where peas may be grown and fed with profit provided they are harvested and stacked. There are few places where the winter climate will permit feeding them on the ground where they grew as is done in the San Luis valley. But there are many high parks and mountain valleys in Colorado, Utah, Idaho, Wyoming, Montana, and other western states where peas thrive admirably and only the Winter's snowfall pre- 
vents their being fed as readily as in the San Luis valley. There is no better feed for old ewes, or for lambing ewes, than peas. The whole plant has a similar composition to milk, it rebuilds wasted tissue and creates new flesh.

\section{ALFALFA-FED COLORADO LAMBS.}

The front range of the Rockies sends forth a number of refreshing streams, creeks and rivers, from the Animas river at Trinidad up to the Arkansas in middle Colorado and the forks of the Platte at Fort Collins. Early in the settlement of Colorado it was learned that alfalfa grew wonderfully well on the plains, where, supplied with water by irrigation the difficulty seemed to be to use the alfalfa. Finally some man tried feeding it to sheep, then to lambs; grain was fed with it. A few car-loads of the lambs went to Eastern markets; the killers tried them and pronounced them extraordinarily good and the Colorado lamb industry was born.

Colorado lamb feeding has had its ups and downs. In the winter of 1898-1899 the feeders lost nearly all the hay they put into the lambs, getting back only the manure and pay for the corn bought in Nebraska. In other year's they have made very large profits. At intervals they have tried feeding other things - calves, wethers, ewes to lamb-in the feed lot. The wethers and calves are mostly eliminated now and lambs are fed on an ever-increasing scale. It is a settled industry, not without its risks yet as certain of profit as any feeding business can well be. 
Colorado lambs are the product of Colorado alfalfa and Kansas and Nebraska corn. There is sometimes a little locally-grown wheat or barley fed, when it is cheap enough, but shelled corn and alfalfa form probably 95 per cent of the foods used.

In early days the Colorado feeders depended almost altogether upon the lambs of New Mexico and southern Colorado for a supply of feeders. The reputation of Fort Collins' lambs was made first with these Mexicans. In more recent years lambs have come there from other regions, notably from Utah and Wyoming. The process of feeding lambs in Colorado is admirably simple. There are yards built of six-inch boards, with cracks between them wide enough to permit the lambs to thrust their heads in and eat between them. Hay is then piled along these fences right on the ground (which is usually dry in that sunny clime) and the lambs eat it standing with their necks through the fence. Two or three times a day men go along and throw the hay up afresh. The hay is drawn from great ricks standing in the alfalfa meadows. Little of it is ever put in barns, which hardly exist in the sense that they are used in the East.

Grain is fed in flat-bottomed troughs in the yards. There is often an arrangement of yards so that one may be used as a feeding yard for two or more pens. In that way the grain may be put in before the sheep are admitted. When the gates are opened they come in with a rush.

When first the lambs are received they are 
carefully dipped and then given, usually, a preparatory course of alfalfa feeding before having any grain. When they are introduced to corn it is fed in very small amounts, slowly and steadily increased until finally they are eating about all they desire. That amount will be be-

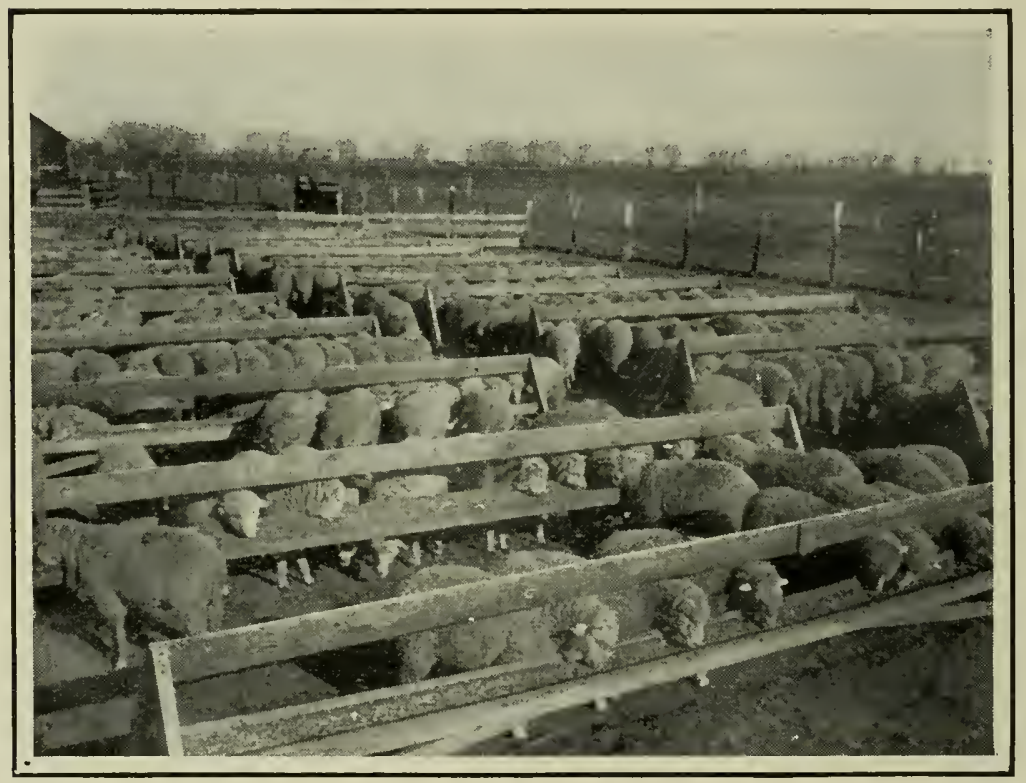

RACKS FOR FEEDING GRAIN.

Photo from Wilcox, 1902 Year Book, Bureau Animal Indus., U. S. Dept. Agr.

tween two and three bushels per day to the hundred head. It is found best to feed corn in regular rations two or three times a day rather than to use "self feeders," such as are used in the Northwest for feeding light screenings. These self feeders, by the way, are merely bins having troughs at the lower edges on each side, 
with narrow openings through which the screening's descend.

Very few of the Colorado feed yards have sheds attached to shelter the lambs. Little rain falls and the snow is light and dry. Windbreaks are found desirable. Water is pumped

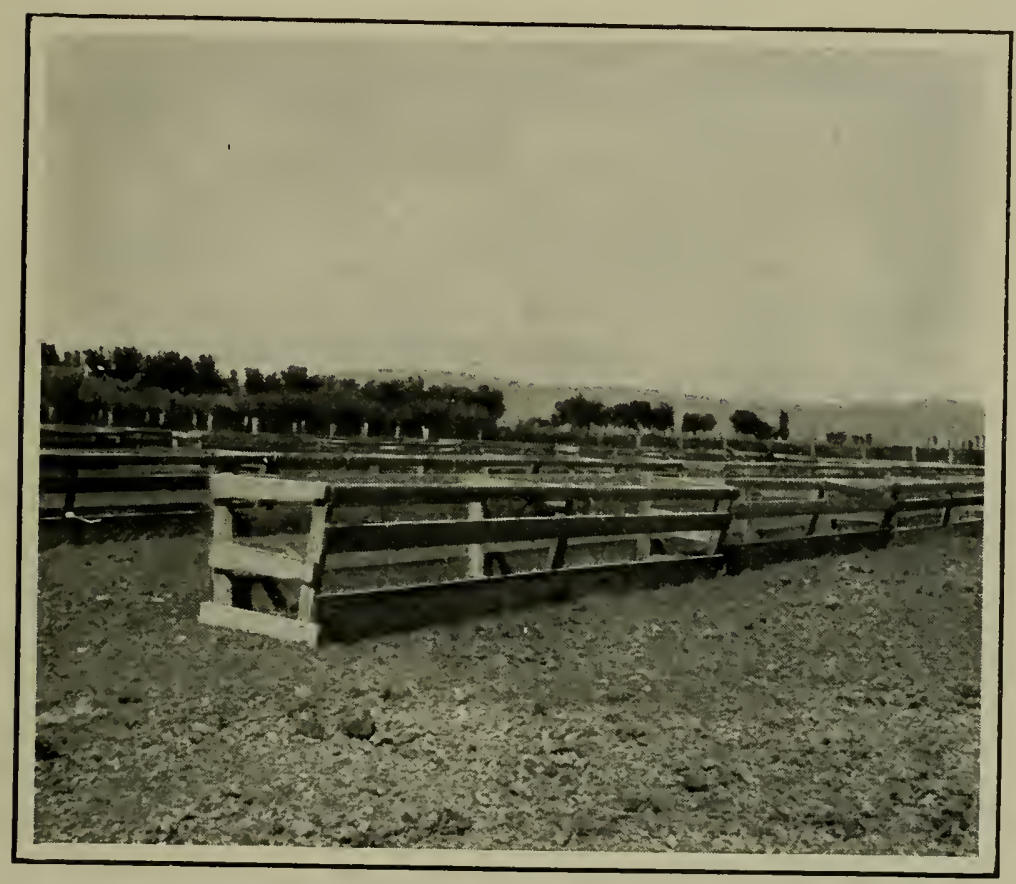

BOX RACK FOR FEEDING ALFALFA.

From Bulletin 31, Bureau Plant Industry, U. S. Department of Agriculture.

by wind power and supplied abundantly in troughs, which are kept clean.

Most of the Colorado lambs are sent to market with their fleeces on. The gains secured are excellent, lambs reighing 55 lbs. when put on feed often weighing $85 \mathrm{lbs}$. when ripe, and 
better gains are sometimes secured. They come to the markets of Kansas City, Omaha and Chicago in solid train loads, and owing to their good quality and even ripeness they sell at the top of the market.

There seems a distinct quality of goodness diffused through an alfalfa-fed lamb, and it is difficult to make as good on any other ration. The healthfulness of the diet is attested by the very great evenness of lots of alfalfa-fed lambs, though this is in part accounted for by the regularity and moderation of the feeding

There are other alfalfa feeding districts in Kansas and Nebraska where the business is carried on very much as in Colorado, having almost as good weather though not usually as good alfalfa. This is owing to the greater liability of rain falling on Nebraska and Kansas alfalfa and to the careless methods of haymakers caused in part by scarcity of labor. Corn is plentiful in these feeding yards and is sometimes fed with greater freedom than in Colorado, though without corresponding increase in gain. The truth is that a lamb can not be forced as a pig can by feeding an excess of grain; he must make a large part of his growth from coarse forage and over feeding with grain is a dangerous proposition.

Then there are regions where men attempt to fatten lambs with wild prairie hay or sorghum, with corn. Large, well-developed lambs will finish fairly well on such rations, though at considerably greater cost than when alfalfa is fed. 
Prof. E. A. Burnett of the Nebraska Experiment. Station has shown that, comparing alfalfa hay and prairie hay with corn, the alfalfa-fed lambs made 5: per cent greater gains than the prairie hay-fed lambs. The addition of 16 per cent of oilmeal to the grain ration of the prairie hay-fed lambs increased their gain 26 per cent.

The writer has often demonstrated in his own practice that lambs can not be fed with much profit without a large amount of protein in the ration, and alfalfa or clover is the best and cheapest carrier of available protein.

In Nebraska and elsewhere lambs are quite frequently turned directly into fields of standing corn and permitted to do their own harvesting. Sometimes rape is sown in the corn at time of last cultivation to add to their supply of forage. Two to four pounds per acre of rape seed are sufficient It is better to let this last cultivation be fairly early so as to give the rape a start. Should the season prove showery the rape will come on and add greatly to the value of the feed.

There are certain points to be observed in pasturing down corn with lambs. It is not a practice adapted to feeding very thin, light lambs, since they require too long a feeding season. It is not a good practice in a wet region, or on a soil readily tramped into mud and damaged thereby. Once the lambs are accustomed to the corn they should not be taken away from it else they will on return overeat and die in consequence. Salt should be before them at all times. 
The writer is of the opinion that the one valuable feature of this practice is the cheapness of its execution. There is certainly some waste, unless pigs follow the lambs, and in some instances at least there is a high death rate owing to the impossibility of limiting the amount of corn eaten. However, as a usual thing the lambs learn slowly to eat the corn, finding it hard to shell, and do not founder.

Mature sheep are sometimes turned into the cornfields to glean their own harvest. There is probably more danger of founder in old sheep than in lambs, since they the more readily begin to eat the ears. It may be said here that it is unsafe to turn Native sheep in the cornfields, as being accustomed to corn they will get too much of the grain, while their Western kindred will take more readily to the fodder.

In conclusion it may be said that the Western feeders have very great advantages in their cheap and abundint forage and grain and their mild, sunny climate They achieve success by close attention to details; the lambs are fed with very great regularity as to time and anount. One man will feed 2,500 or more, so the labor cost is light.

Their disadvantage is in their remoteness from market, entailing higher freights, and in the speculative character of the Western men which leads many of them to jump from one industry to another, feeding few lambs one year and very many the next, jumping often just at the right time to fail to alight on their feet. 
It is a curious fact that in Nebraska and Kansas few farmers feed their own grain and hay, preferring to sell it to great operators who feed in central plants many thousands of sheep and lambs. Thus is the manure lost to the farms that will some day need it, and mountains of richness are heaped up outside of feeding corrals to prove an embarrassment to the owner. This system is wrong and invites disaster. The man who produces the food should feed it at home. A man can afford to devote his time to 500 sheep or lambs in winter; thus he has left on the farm most of the fertility taken from it in crops and can readily return it to his fields. Feeding his own crops he rums small risk of loss in his operations

FEEDING MILL SCREFNINGS.

Minnesota is the great state at present for feeding screenings. These screenings come from the great mills along the upper Mississippi and elsewhere. They contain a little shrunken wheat, a good deal of weed seed, largely of pigeon grass, and bits of straw and trash. There are many thousands of tons of screenings available every year. Most of this material is used by the large sands of tons of screenings available every vear. Most of this material is used by the large operators, who feed from a few to many thousands. They generally use sheds provided with self-feeding bins holding many bushels of screenings. The management of one of their 
plants is admirably simple; the lambs are bought, usually of a fairly good size and quality, dipped and turned into the sheds, where they remain until fat. Usually no hay is fed or required, the bulky nature of the screenings rendering them all sufficient for distending the lamb properly.

At one time large profits ensued from feeding lambs on screenings. The millers, curiously enongh, became aware of this fact and began steadily to raise the price of screenings. As lamb prices advanced so did screenings, till at this writing the margin is not large and a bad year would wipe it out altogether.

\section{SHEEP FEEDING IN THE CORN BELT.}

In the corn belt proper the conditions for feeding are good generally so far as abundance of food is concerned. Corn is a staple and must find a market. Hay is readily grown, and late experience has shown that wherever there is limestone soil, or sweet and fertile soil, alfalfa may be grown. Red clover is usually easily grown. Thus there is a ready source of food for sheep.

The climate is another matter. Sheep want dry footing and dry coats. They can not endure muddy yards and wet dripping skies. Therefore before we attempt to feed lambs we must provide a somewhat artificial climate. This is done with shingles to turn off the wet. Mature sheep are very often fattened altogether in open yards and Western Merinos have 
fleeces that turn rain fairly well, but lambs in the exposure do not thrive and it is folly to attempt feeding them east of the Missouri river without some shelter from rain. North of Illinois, however, where rains are infrequent and

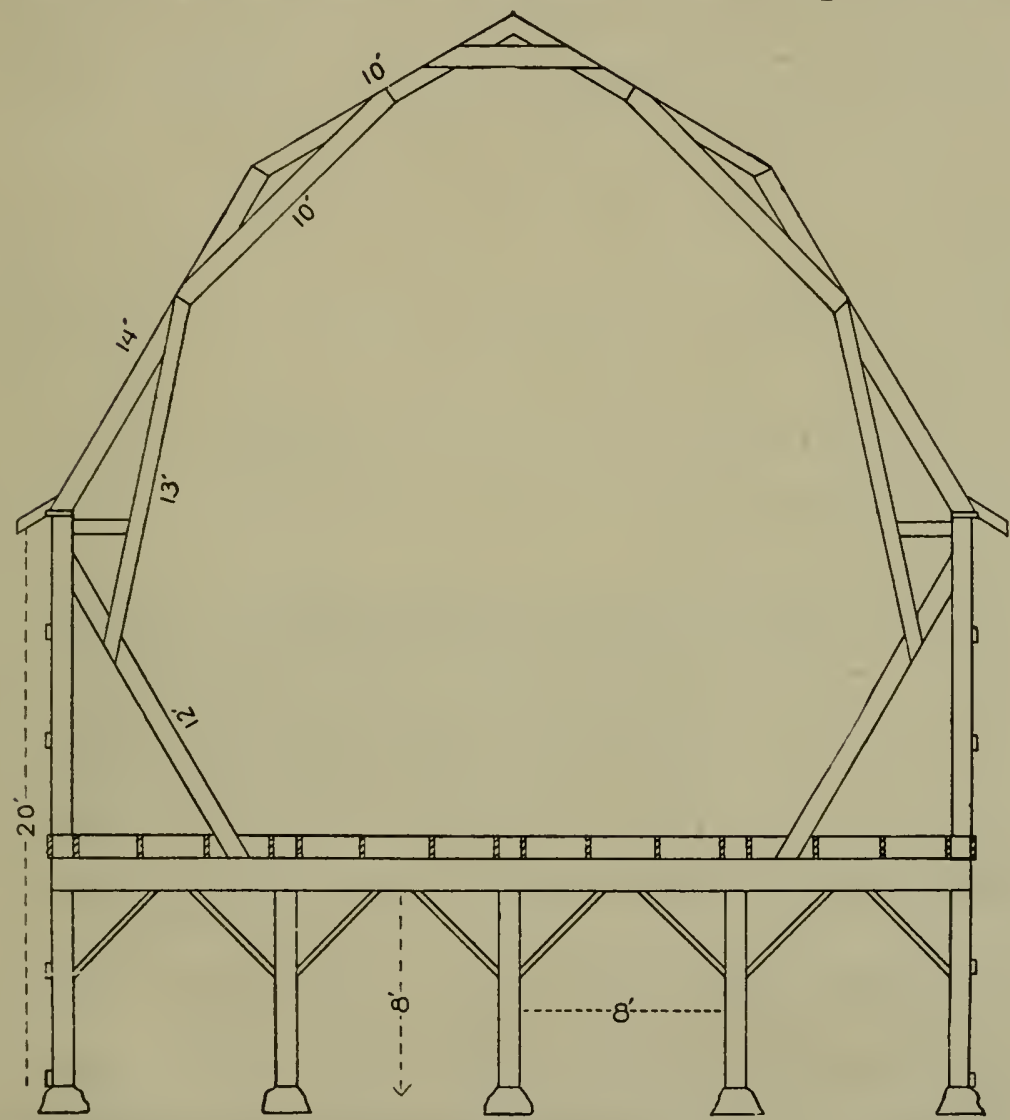

CROSS-SECTION OF MODEL SHEEP BARN, SHOWING FRAME.

snows light and dry, sheds are sometimes dispensed with, but that is really outside the corn belt.

The character of the barn or shed used is 
not essential. It may be a simple roof open on two or three sides, to which hay will be hauled on wagons from ricks. The writer has such a feeding plant and uses it to good advantage. It may better be a barn of two stories, the upper one stored with alfalfa or clover hay. On the lower or ground floor the lambs are fed. Their part should be eight feet high in the clear, all in

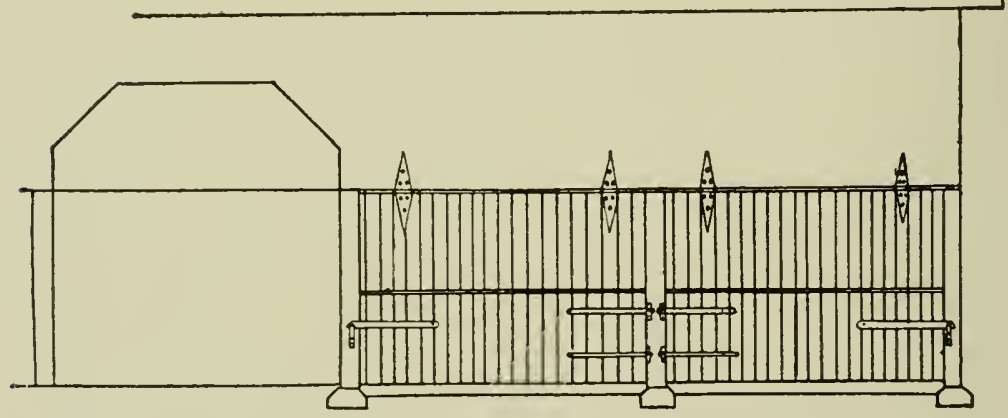

SIUE VIEW OF MODEL SHEEP BARN, SHOWING DOORS.

one large room, which may be divided as desired by use of racks or movable panels.

Through this room there should be opportunity to drive transversely through nearly or quite every bent or space between posts. To accomplish this doors must constitute the whole length, preferably on the north and south sides of the building, which may well stand east and west. 
Thus the two sides will be composed entirely of doors so far as the lower story is concerned. Doors cost little more than ordinary siding to construct. These doors should be divided transversely at a height of about four feet. The lower half will swing from the post just as a gate swings, while the upper half will be hinged at the upper side, and raise up outwardly. Thus the lower part of the door may remain closed to restrain the sheep, while the upper half is lifted to admit air and light. And air may be admitted and storms kept out, the outward swing of the upper door throwing drip of rain away.

These upper doors will in mild weather be raised high and left up. In time of storm or extreme cold they may be closed on one side or the other.

An abundance of fresh air is absolutely necessary to the lamb. He will not thrive or fatten well without it. He will thrive better in the open field than in a close foul-smelling, unventilated barn or shed.

Nor does it matter much after being once on feed whether the lamb barn is warm or cold. In truth the lambs often thrive better to have it moderately cold. It is not necessary or best to have it warm enough so that water will not freeze within. If the user is uncertain whether he will remember to open these upper doors he had better not hang them at all, but leave the space open instead. The cold and snow that will blow in will do less injury to the fattening lambs than the deprivation of air would do.

'The barn should have no floor save the nat- 
ural earth. Water troughs of concrete are best and they may be built so as to be half within and half outside of the barn, on the sunny side. These tanks may be of large size, thus obviating the necessity of storage tanks, say $10 \times 12$ feet and about 18 inches deep. It is of no use to make a lamb's drinking trough very deep, and in fact there is danger that they may drown in a deep tank, since they will sometimes jump into it.

The amount of room desirable in a feeding barn is about 5 square feet to a lamb aside from the racks. In practice one will need about 8 square feet gross, which will give him room for his racks. To feed, then, a carload or 350 lambs, he needs a barn about $36 \times 72$ feet. Some feeders crowd the lambs more than that but they will not thrive as they ought nor ripen evenly unless all have room so that they may eat at the same time.

The next thing is the feed rack. Various types are in use and all have some good qualities. After much experience with various types the writer finds this form best (see illustration). It is made of two $1 \times 6^{\prime \prime}$ boards spaced 24 inches apart, with ends and a bottom of matched pine flooring. This makes a shallow box or feed trough. At the corners are legs of $2 \times 2$ inch stuff, 40 inches high. The vertical slats are of $1 / 2$-inch stuff 3 inches wide and are spaced $61 \%$ inches apart. The top of the box should be about 12 inches high. In this rack may be fed any sort of grain or forage. The wide openings between the slats permit sheep to 
thrust their heads clear in and there they will stand quietly eating until they have consuined the ration with little waste, whereas if the vertical slats are placed close together the lambs will pull the hay out, dropping it beneath their feet. This is a cheap form of rack, durable, easily made and as effective as any. The length should be to fit well with the type of barn used, so that rows of these racks will, when required, make divisions or fit between the posts of the basement.

Now, with the feed racks in place, with water, and the mow above stored with clover or al-

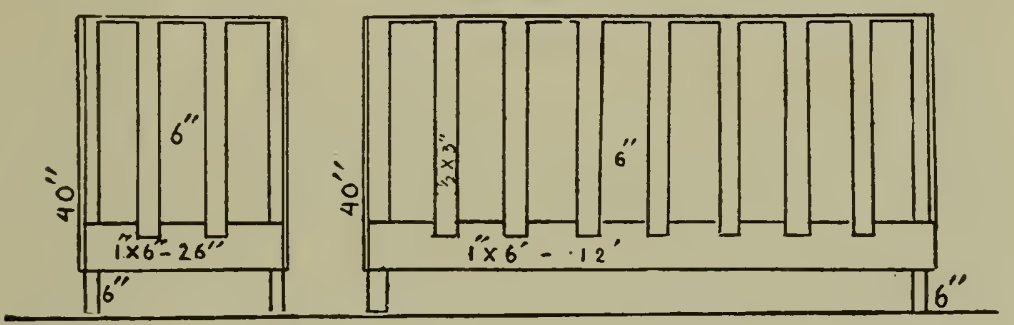

TWO VIEWS OF FEED-RACK.

falfa hay, which should have been early cut, we are ready for the lambs. First a word about the rard. It should have in it about one half greater capacity than the roof covers, not more, and if it can be sloping all the better. It should be well graveled with rather coarse gravel, spread smoothly. If it can be concreted all the better, since it will then be very easily kept clean.

The reason for having a small yard is so that it may the more readily be kept dry and clean, and because in a large yard there is too much 
waste of manure. Lambs in the fattening pen do not need much exercise and are the better not to have it.

A word, too, about hay. With timothy hay in the mow no attempt should be made to fatten lambs. Oat straw is as good, or as bad. Bright shredded corn stover is a little better, and when fed in connection with abundant wheat bran and a little oilmeal it will serve very well. Without this extra supply of protein shredded corn stover will not profitably fatten lambs.

Now let us bring the lambs home. They come from the cars half famished, though there are seldom any dead ones among them. What a sight it is to see them devouring the grass along the roadside as they go from the station to the farm! It is impossible to hurry them, nor should one attempt it; let them take their time. When they reach the farm we will turn them first into some grass pasture where there is water and there they may rest for two days, supposing it to be yet fair and dry weather. Then they must be dipped, unless we are willing to accept the dipping at the yards. And at once they go to their pens and are initiated into the mysteries of barn life. We will put about 500 in a pen or what the barn holds. The writer feeds 700 in one barn, which seems not to be too many for all to thrive. There must be racks enough so that all the lambs may find places to eat at the same time.

We fill the racks moderately full of alfalfa hay and watch the lambs eat it. At first they 
are timid about going into the barn, but soon they find their way about and learn where the food is. And then how they do eat! We will feed them twice a day, at the same time each day, and let them rest. The water we must watch, that it is kept pure enough for man to drink and always in supply. Salt we will give at first by dissolving it in water and sprinkling it over the hay; it may be put on the coarse stems that they leave. After doing this for a few days we will find their appetite for salt satisfied; then we will fill a box with salt in one corner of the barn and let them have access to it at their own will. But if we could take time and trouble to put brine on their hay all through tne feeding season that would be the better way, making them eat the coarser parts with relish and avoiding all danger from getting too much salt. There is, however, little danger of that if the lambs are first carefully introduced to it until their appetite is appeased, then given access to it at all times. On Woodland Farm it is the custom to roll salt barrels into the barn and saw out two or three staves, letting the sheep consume it as their appetite indicates they should. But when the writer fed his lambs in person he preferred the brining method.

We will feed no grain at all for the first two weeks, unless the lambs chance to be unusually vigorous and therefore able to take it sooner. It is wise to let the lambs get their strength before attempting to feed them grain, to which they are not accustomed.

In some cases the lambs will be so weak 
when they have found their journey's end that it will be wise to strengthen them by feeding a little wheat bran in connection with the clover or alfalfa hay. There is scarcely anything more readily digested and strengthening than wheat bran and it seems especially suited to the needs of the lamb. In truth, the one reason why the writer is not using it and advocating it, is its heavy cost, now that the dairymen have learned that they must have it.

In former years, before they had much alfalfa hay and when bran was far cheaper than now, the writer and his brothers fed many tons of it to lambs with very gratifying results. They made it profitable to feed it, though later when they had abandoned it for alfalfa hay produced on their own farm, the profits of lamb feeding were greatly increased.

The cost of growing lamb mutton in the days when timothy hay, oat straw and shredded corn stover were used in connection with wheat bran and oilmeal for the ration, with corn, was about $\$ 6.25$ per hundred pounds. Afterward, when the only feeds used were alfalfa hay and ear corn, the cost dropped to $\$ 3.50$ per hundred.

There are troubles that come to weak Western lambs upon their first introduction to the Eastern feed lot. Sometimes they develop sore mouths in a very contagious form. The remedy is to rub off the scabs with a corn cob and cover the sore places with a little undiluted coal tar sheep dip. This remedies the disorder in short order. It is wise to take it in hand early. 


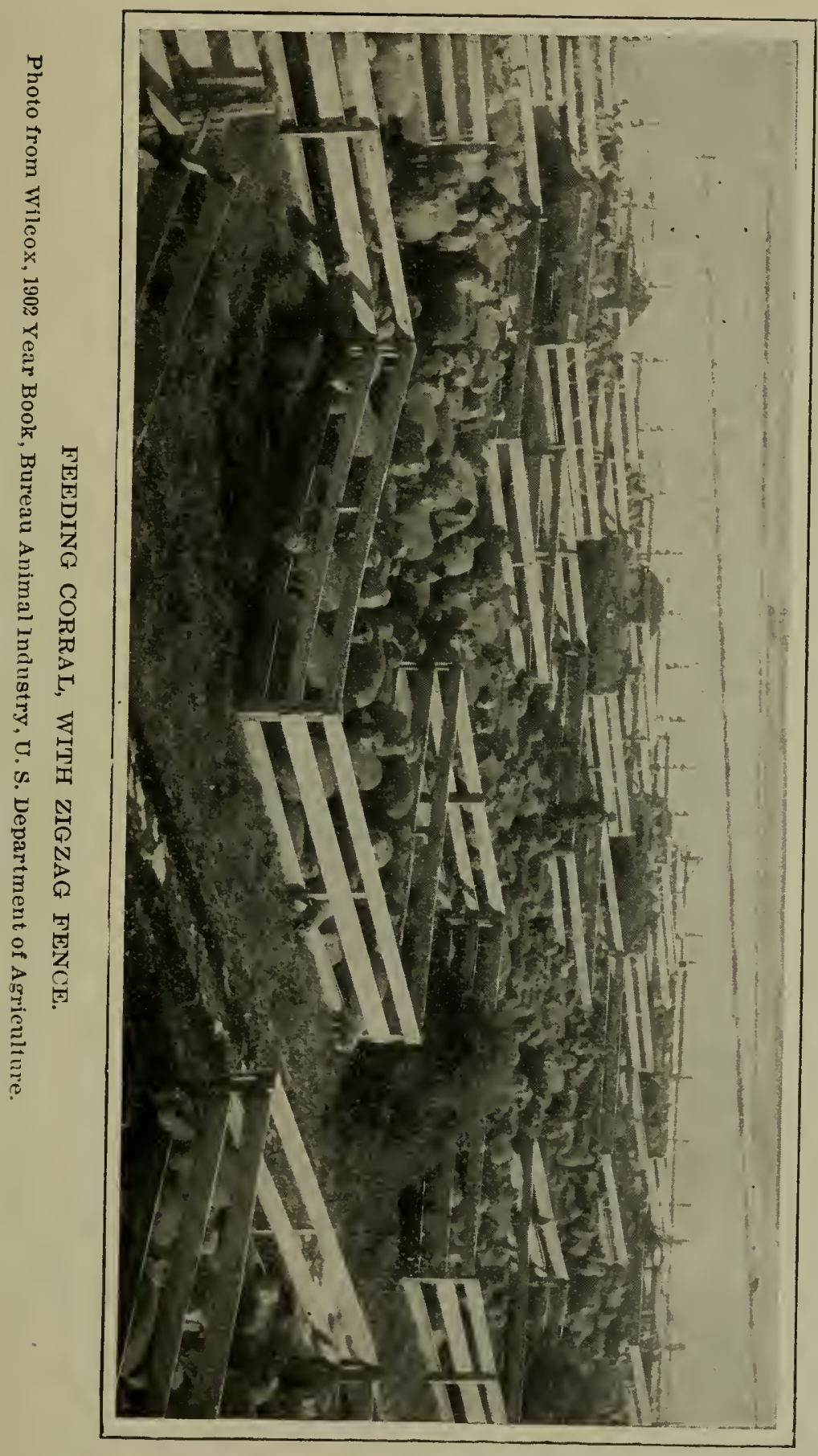



Sometimes, if the yards are a bit muddy, sore feet develop. These ought to be promptly treated, either with blue vitriol or butter of antimony and the yard made dry. Air-slaked, dry lime scattered where they will get it on their feet will help.

Now we have the lambs used to their new home and fed up on alfalfa until they are strong again; we are ready to introduce them to grain feeding. It is a good practice to turn them out of doors while we put in feed for them, leaving them out until the racks are all filled. If oats are plentiful and cheap enough we can give the first grain food of oats, mixed with bran. There is nothing better than this. Scatter the grain very thinly along the bottoms of the racks, having first cleaned them out well. A quart to a rack will be an abundance, less will be better.

Put the hay in after the grain, loosely. Be careful with nice bright early-cut clover and alfalfa not to feed too much; they will waste it. They may as well eat it up almost clean.

Let the lambs come in. Throw open several wide doors at one time so that they will not crowd. Little by little they will learn the taste of the grain. Do not increase the amount fed until you feel certain that most of them are seeking it. Then let your increase be very gradual.

Corn, in the cornbelt, must be the main part of the fattening ration. Now to introduce that. Take ear corn, if it is at hand, and chop the ears up with a hatchet into nubbins about an 
inch long. Strew a few of these nubbins in each rack. Next feeding time strew in a few more. Increase very, very slowly as they learn to eat the corn, till you are giving them several ear's to a rack. Cut the bits longer and longer, till at last you are merely making two pieces of an ear. Finally stop breaking ears at all, and feed them whole.

You should be about 45 days in getting them on to what is practically a full feed of corn. And then do not give them all they want, but give them nearly all. If when on full feed they are eating as much as they desire within a very few grains you have done well. Be sure they clean it all up at every feed and come eagerly for more at the next feeding time.

Now when they have gotten to eating corn well rou may as well drop the bran and oats, merely because of the expense of feeding them, since oats are usually dear. If they are cheap enough continue to feed them, and so of barley, in connection with corn; they form an admirable ration. If a portion of the hay must be prairie hay, oat hay or timothy, in fact any grass not a clover, you can not discard bran, since there is too little protein in the grasses to make the lambs grow. They need to make a lot of flesh and bone, too, besides the fat. If you have them to spare feed a small amount of soy beans in connection with corn. Soys are rich in protein, some varieties having above 35 per cent. And the soy straw, if it has not been wet, is relished though too coarse to be eaten clean. Oilmeal 
in connection with bran, where grasses or corn stover form the hay, works admirably.

There is more clean profit, however, in feeding the simple ration of alfalfa hay and ear corn and nothing else, unless corn silage. No feed will make better or more marketable lambs.

Once on full feed the programme should be an unvarying one. At some regular time in the morning, not too early, say half an hour after sumrise, the lambs should have their morning feed. 'The water should be looked after and the lambs allowed peacefully to consume their allowance. Shortly after noon they will lie down to rest and sleep. Do not ever disturb them; assimilation takes place best when they are asleep. Try to feed hay with judgment, so that they eat it nearly all and yet have enough.

At about four in the afternoon begin feeding again. Later will serve, so you observe the same time each day. Feed just as you did in the morning.

One hundred lambs will eat about $21 / 2$ bushels of corn daily when on full feed, unless they are very small lambs. A thousand lambs will eat more than a ton of hay daily. It will take about $21 \%$ bushels of corn to fatten a lamb and 12 to 20 tons of hay to the hundred lambs, depending on how long they are kept.

Soon the stems of hay will accumulate in the bar'n and make a good bed. The corn should be cut and the stalks fed in the open rard, which will thus be kept dry and clean. The blades of the corn will be pulled off and eaten and the hay thus helped out. 
Soon the manure spreader must be started taking out the accumulating manure from the shed. Every day a few loads may be hauled away and spread on the frozen ground; thus there is avoided the accumulation of a vast amount of manure to be cleared away at one

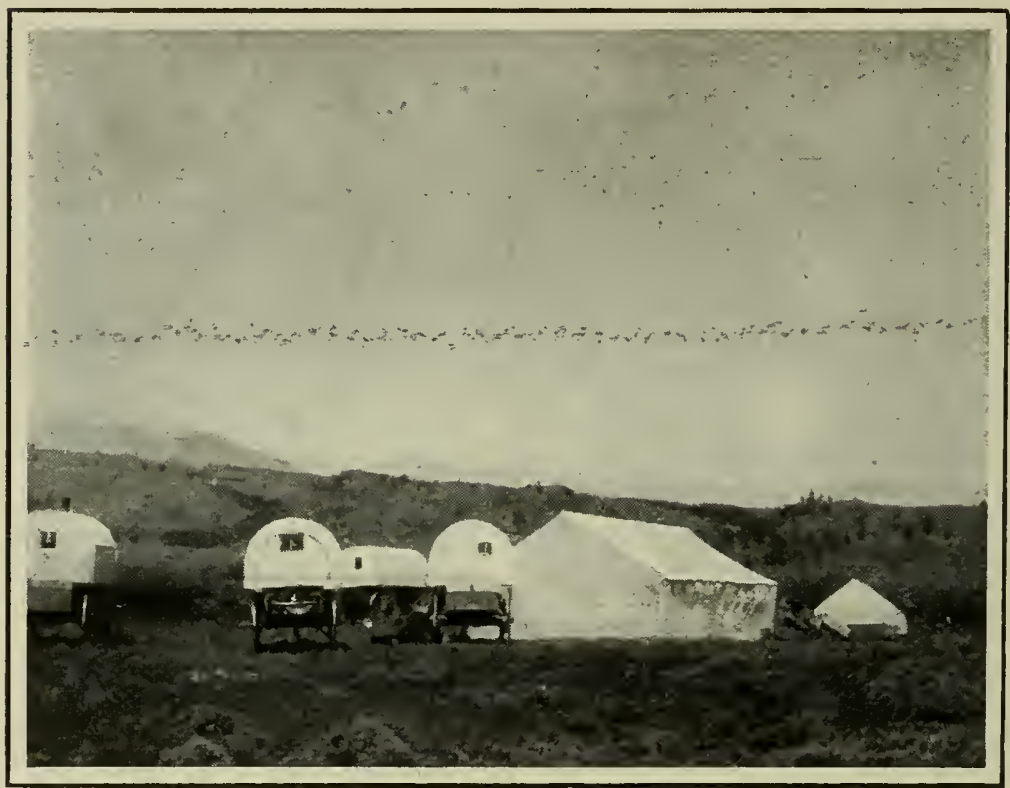

SHEEP WAGONS.

Photo from Wilcox, Annual Report B. A. I. 1902, U. S. Dept. of Agr.

time in spring when every sort of work is crowding.

Late in March the lambs may be shorn, if they have not already gone to market, and the feeding continued for a little time thereafter. When they are ripe they should go to market, otherwise losses are likely to follow, not from 
disease but from disorders favored by too plethoric a condition.

With small lambs it requires at least 120 days to ripen. With larger and more fleshy ones less time is required. With very small lambs in thin flesh 180 days are none too many to induce ripeness. The latter part of the feeding period gives the most profit, since gains are better than at the beginning when the lambs were unused to feed.

It is cheaper to ship the lambs to market clipped, since many more can ride in a car and the freight is no more.

When the lambs are uneven in size it is likely that some will ripen before the rest. In this case a carload may often be sent on and the rest allowed to ripen further.

The writer has sometimes made lambs fed in this manner gain nearly 100 per cent in weight. It is a pleasant business and in the long run profitable. Sometimes a year will come when the price of feeders is too high in proportion to the selling price of lambs and one must figure on the value of the manure to find his profit.

In recent years the writer has varied the treatment outlined by feeding corn silage in connection with ear corn and alfalfa hay. This silage is made from well matured corn, so that it makes a street silage, containing little acid and having in it no mould. Lambs eat this greedily and seem to grow much more rapidly than when it is withleld. About 21/. to 3 pounds of silage makes a ration for a day to a 
lamb. The writer believes this cheapens the ration materially and perhaps the mutton is better; he thinks it is and has had no difficulty in securing the top price for his alfalfa-silagecorn-fed lambs. When corn is made into silage after it is well matured there is of course a very large proportion of grain thereon and it is tender and succulent and much relished by the lambs. The small amount of acid in the silage is lactic acid, promotive of digestion.

Silage has been fed to breeding ewes with excellent results when it was of good quality and fed judiciously. When it has been acid, or when in immoderate amounts, disaster has followed its use.

In some instances that have come under the writer's observation great losses have come from attempting to feed silage exclusively to breeding ewes. They did well for a time, then went swiftly to ruin, much of it irretrievable. Loss has also come from feeding acid silage.

A silo should not be built with cemented, water-tight floor. On such a floor the silage becomes very acid and trouble follows when it is fed to sheep. The natural earth makes the best floor for a silo.

Never with sheep should sllage form more than half the ration. If this rule is observed and the silage is made from well matured corm. planted no thicker than for the regular crop, it is believed that none but good results will ever follow its use.

Iambs will not consume quite all the coarser parts of the silage. These must be thrown un- 
der foot or cleaned out and fed to cows. The writer has seen great loss from feeding the refused portions of silage to horses. In one instance where quite a heap of it had accumulated in the barnyard eleven horses and mules ate of it. Eleven of them died. There is evidently some principle developd in silage after it has been exposed to the air, perhaps, that is most unfavorable to horses. They die with symptoms resembling spinal meningitis. There will be death loss among feeding lambs no matter how carefully they are fed. Care will greatly reduce this loss, however. The writer has had as low as 2 per cent and as high as 8 per cent. If no more than 4 per cent of loss is sustained no one need shed tears.

Attention to regularity in feeding, care that no doors or gates are left open to admit lambs to feed bins, and always feeding well under the gauge of the appetite will usually keep the death loss very low. With Western lambs there is sometimes danger of their jumping into water tanks if they have access thereto. The feeder should be careful that no sudden fright causes them to stampede in the barn and pile up, which may smother a number.

There is seldom any good accomplished by treating with medicine sick lambs in the feed lot, unless for stomach worms. These should be cleaned out before the feeding begins. The writer has probably lost his full share of lambs and has tried various remedial treatments, but is not aware that he ever helped one. Death, in fact, usually comes from some inflammation 
of the intestinal tract, caused by engorgement of rich food, and medicine only aggravates the trouble.

There will occasionally be loss from gid, or turnsick, which is caused by a bladder worm parasite in the brain. There is no practical remedy for this, though the lamb when first observed will make good mutton.

With regular, rational treatment the lambs will keep in health and when occasionally one dies the owner must console himself by thinking of the 99 well ones, meantime taking off the pelt, salting it well and feeding the fresh carcass to his pigs or chickens.

The writer does not believe it necessary for lambs to be out in their yards during day or night, so the barn or shed is as thoroughly aired as he has directed. When they are confined their urine is saved and the value of the manure greatly increased. Rich green fields spring up as by magic about the lamb feeding plant and when off years come and little direct money profit is seen the feeder can console himself if he has husbanded wisely his stores of manure by seeing the corn reaching toward heaven and flaunting its banners of deepest, darkest green, while following the corn are fine meadows of alfalfa or clover.

When lambs are fed long, until after green grass comes in spring, it is a temptation to turn them out to graze for a time. This is a mistaken practice, sure to result in great loss. The lambs will not continue to gain on grass, even though fed their grain as usual, at least there 
will be a period of reaction when they will actually lose flesh, though if the practice be continued long enough they will gain it back again. It is more profitable to send them to market right from their dry lot.

Sometimes, however, lambs are bought in the spring with the expectation of feeding them off on grass, with corn. This may prove a satisfactory enterprise, if it is carefully managed. The troughs should be placed in a yard or temporary corral in the pasture and when grain is put in them the entire flock must be called or driven within and fastened there for a sufficient time for them to consume their ration. They may then be loosened and permitted to roam where they will until the next feeding time arrives.

The feeder must see to it that every lamb comes up every time. Otherwise he will have cases of indigestion and founder; many will get off their feed.

Sometimes self-feeders are used on pasture. They seldom result well, owing to the essentially short memory and weak original impulse of the lamb. He will not leave his fellows to go for feed when he is hungry, and when he does reach the feeder he is apt to gorge himself thereafter declining to eat at all.

USE OF SELF-FEEDERS.

The writer has used self-feeders in past years in his feeding barns and discarded them entirely. Varjous tests have shown that not only 
is the death loss much heavier where self-feeders are used for corn but the cost of gains is also much greater. If bran is fed it may be fed in a self-feeder, though of course this requires the use of considerable bran, and light screenings are well enough fed in that manner, but for corn, barley or wheat, troughs and regular rations are safer and better.

\section{FEEDING BEET PULP.}

Nearness to sugar factories gives opportunity to utilize the waste product called beet pulp. This pulp is an excellent food but contains 90 per cent of water. Therefore like silage, it is not well to feed it without dry grain being added to the ration, as well as dry forage. A ton of pulp contains about the same feeding value as $200 \mathrm{lbs}$. of corn. This would indicate what the farmer can afford to pay for pulp, a very small amount indeed when he must count the cost of hauling and feeding. It is doubtless a healthful addition to the ration but experiments show that pulp alone with alfalfa hay does not make as good lambs as corn and alfalfa.

There is Jittle bone material in beet pulp, therefore lambs fed on it are said to suffer that lack. It would seem, however, that alfalfa would make good this deficiency. The practical objection to feeding beet pulp in cold weather is its freezing, or its liability to make the yards damp

The quality of meat from these pulp-fed 


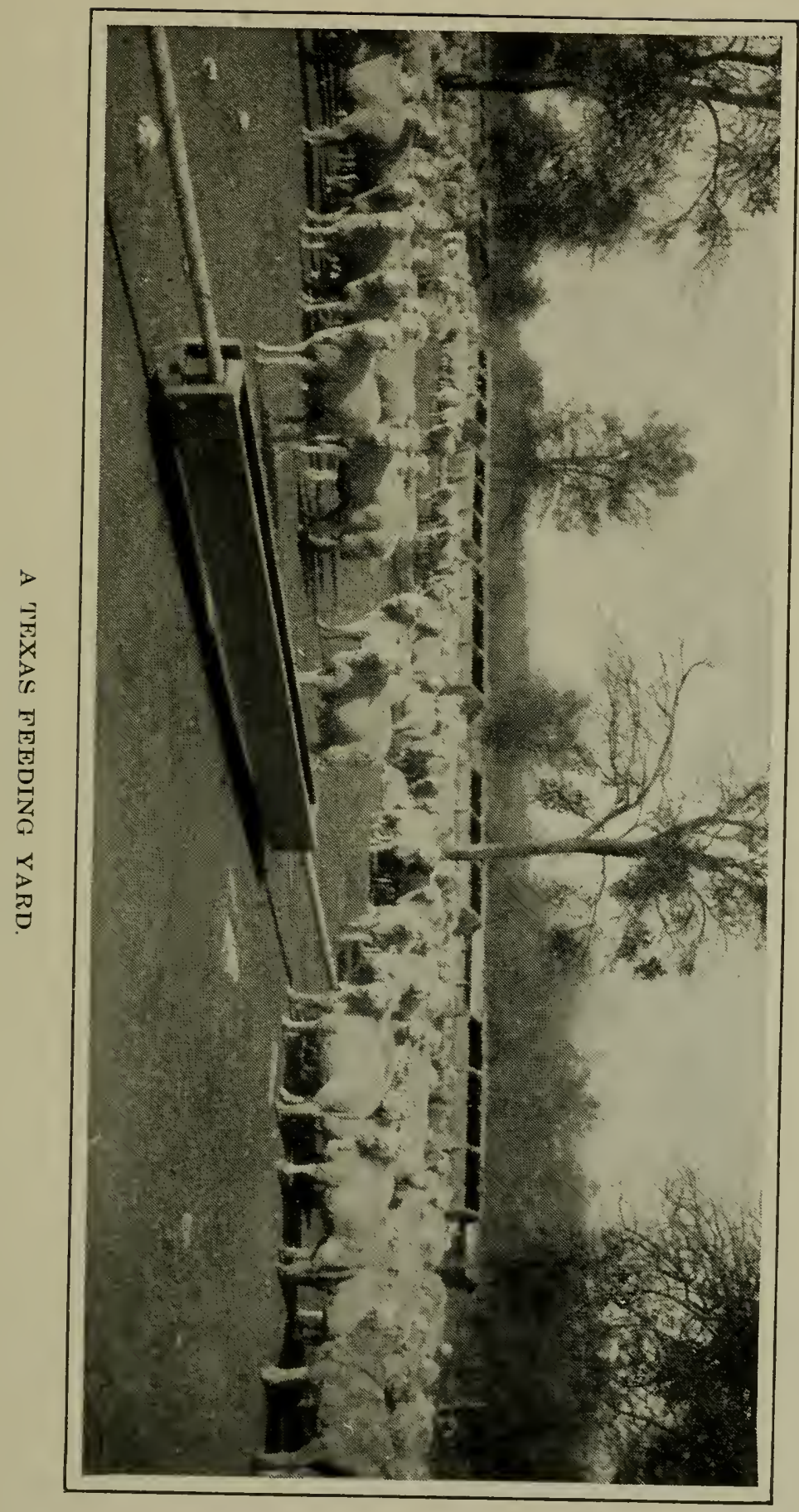



lambs is very good, though they do not stand shipment so well as the corn-fed lambs.

CAUSES OF DEATH IN THE FEED-LOT.

Lambs bor'n east of the Missouri river are often infested with stomach worms. In buying them in the fall to put on feed only the thin ones can be secured, and these are almost certainly infested. These lambs will die rapidly in the feed lot unless they are thoroughly treated to eradicate the worms.

Lambs free from parasites should not die. When they do it is because of some mistake in their management, or some accident.

'The heaviest losses that ever occurred to the writer came from feeding a large amount of oat hay, not well cured, and on which had been put too much salt in an effort to keep it from moulding. Very many lambs die from affections of the bladder causing retention of urine, or "water belly." There is some evidence that the too free use of oat hay will cause this.

Many lambs are lost from indigestion caused by feeding too much grain, or by introducing them too suddenly to grain. Seventy-five per cent of all the lambs dying in the feed lot die from indigestion caused by over-eating of grain.

In investigating the causes of death losses the writer has found these significant illustrations. One man fed his lambs in the sheds, feeding corn, clover hay and corn silage. He did not feed too much grain, but he did not turn the lambs out when he fed them. Thus some of the lambs began eating sooner than the others 
and naturally ate too much. Another man had heavy losses because his lambs had not enough good hay and too much mouldy ensilage. Had they had a sufficiency of hay it is doubtful if they would have eaten the mouldy portions of the silage. It is not well to feed mouldy silage to any animals. We have lost lambs through the carelessness of feeders in leaving the granary door open. We have lost lambs from an awkward arrangement of our sheds, having an $\mathrm{L}$ with a long and narrow extension. This prevented perfect distribution of the lambs. Something frightened the lambs from the $\mathrm{L}$, maybe a house cat, or a rat or barn fowl, and they fled to the main part of the shed soon after they were turned to their feed. A few ventured and ate too much corn. They died. The writer has had a death loss of less than 1 per cent, and as high as 6 per cent. No one need feel disheartened at a loss of three per cent between purchase and sale.

To absolutely prevent loss it is quite necessary to start with healthy lambs; to rest them and begin by feeding very moderately, using good clover or alfalfa hay as the basis of their ration and to introduce them to corn very slowly and gradually; to increase the ration so slowly that they will be unaware of the change - to feed always with perfect regularity and always a little less grain than they will consume and to give attention to very thoroughi ventilation and the supply of pure water. The salt supply should be always conveniently available. Nothing should ever frighten the lambs. 
Stampeding them will often cause death. When lambs are lying down they should never be disturbed. They fatten most while reclining and asleep.

\section{PEAS FOR LAMBS.}

In some regions where the Canada field peas thrive, or near the factories where split peas are prepared, peas or pea refuse is available for lamb feeding. There is nothing better. Lambs grow, thrive and fatten admirably on this food. With peas for the grain ration it is not so material that alfalfa be fed, since peas are exceedingly rich in protein.

\section{THE BUSINESS OF LAMB FEEDING.}

The writer thinks it unnecessary to ask pardon for thus devoting so many pages to the description of the lamb feeding industry, based on Western lambs, corn and alfalfa.

It is easy to see from the immensity of the ranges and the constant supply of lambs coming from them, together with the great and everincreasing demand for lamb mutton in the United States, that this industry is one not destined to soon diminish in importance. Old sheep are fed in relatively decreasing numbers and the demand for strictly "baby lambs" is absorbing a greater and greater proportion of the farm-grown lambs. Lamb feeding as a speculation may result disastrously, indeed is certain to do so at times when feeders are bought dear, feeds are high in price and lambs sell cheaply in spring: but the farmer who fits 
himself for the business and feeds with care and steadiness year by year will find his profits encouraging and his farm increasing steadily in productiveness. The work is such that farm labor finds employment the year 'round, thus good men are attracted to lamb-feeding farms.

FEEDING OF OLDER SHEEP.

After the lamb comes the yearling in point of merit as a feeder. Very often the yearling was a light lamb, too light the owner thought to put upon the market in the fall. In the feed lot yearlings thrive. They do not always have perfect front teeth and are therefore less able to eat ear corn. If bought light enough their gain is very good. They may be fed best in just the way described for feeding lambs and their treatment need vary in no particular save one. Should there be any ewes among these yearlings the feeder must be very careful that they do not get access in any way to the ram, or that there be no rams among the lot when bought.

Ewes in the feed lot will not very often drop living lambs. If they are sent to market before lambing, supposing they show strong signs of pregnancy, they are subject to dockage and may possibly be thrown out by the inspectors.

FEEDING MATURE IVETHERS.

There are advantages in feeding wethers that lambs do not possess. They are big and strong and hardy. They do not die so easily. They do not need shelter so much as the lambs need it. They will thrive quite well on corn and corn 
stover with little hay. They are adapted to a ruder, rougher style of sheep husbandry than the lambs.

'There are, howerer', some few essentials to successful wether feeding. First and most important is to buy the right class and to buy them cheap enough. With the lamb one can afford better to pay too much, since the gain in weight may be so great that the excess of cost may be offset by the good gain in pounds and profitable price for it. With mature sheep much smaller gains can be had and if there is not a material advance in selling price over cost loss is apt to follow.

In lamb feeding there is often more profit in buying small, immature lambs. With wethers, on the other hand, the bigger and better matured they are the better the chances presumably are for profits in feeding them-that is, if they have been bought low enough so that the selling price will be materially better. There is thus the advanced gain on the first cost besides the pay for what weight is put on. Opinions differ as to what advance in price the feeder of mature sheep must have in order to make a profit. Certainly it depends much upon the selling price; if that is high there is need of less margin than if it is low. In general there shou!d be a rise of a dollar per hundred to make feeding of mature sheep profitable. This also depends much upon the price of wool. When wool sells as high as 25 to 30 cents per pound the profit of feeding mature sheep is naturally much greater than when wool is low. Then also 
one can afford to feed the heavy shearing types, which do not naturally make so good gains in weight as do the more open wooled and light shearing sorts.

In feeding sheep there is need for much less protein in the ration than when lambs are fed.

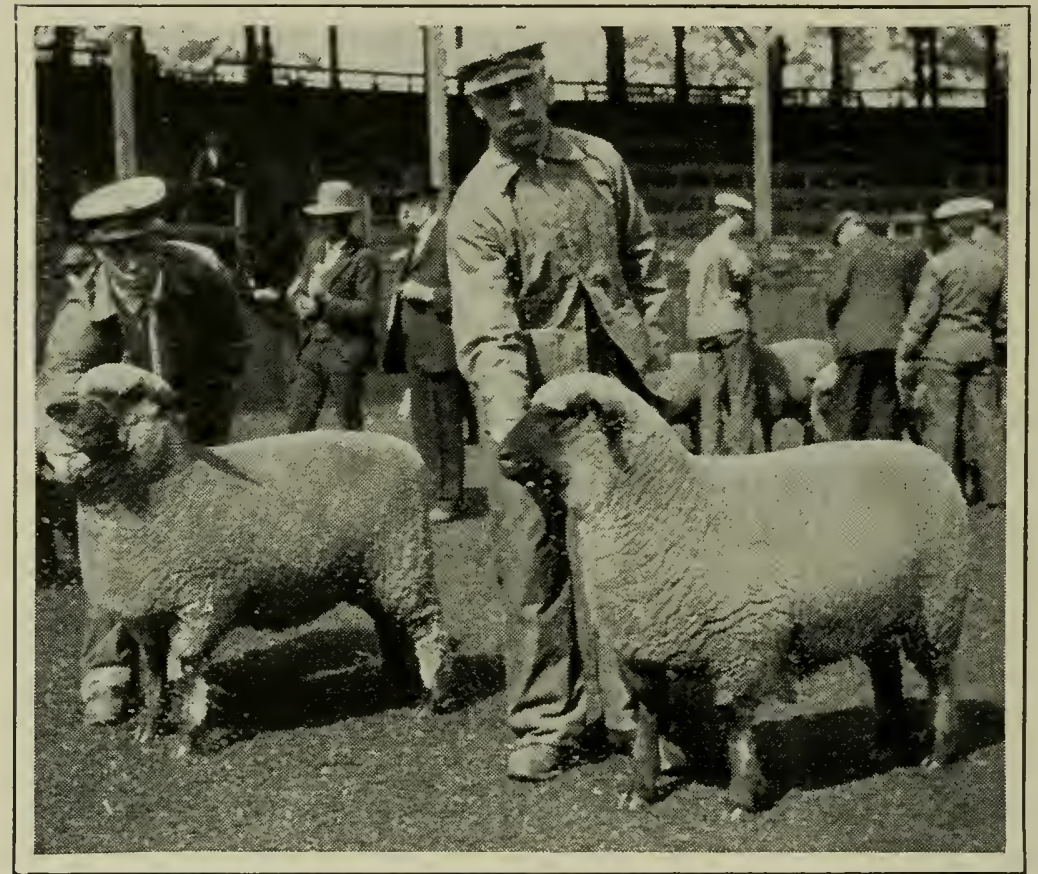

A PAIR OF HAMPSHIRE LAMBS.

The reason is plain: the mature sheep has its frame alleady built; has nearly as much muscular structure as it will ever have. It has been demonstrated that feeding does not materially add to the fiesh of the animal, unless perhaps in case of considerable emaciation, but puts on fat instead, either intruding it between 
the muscles, or, what is usual with the sheep, depositing it in masses partly upon the inside and partly distributed over the body.

The lamb, as has been noted, has its framework ret to build, therefore it needs and must have abundant protein, thence its thrift when

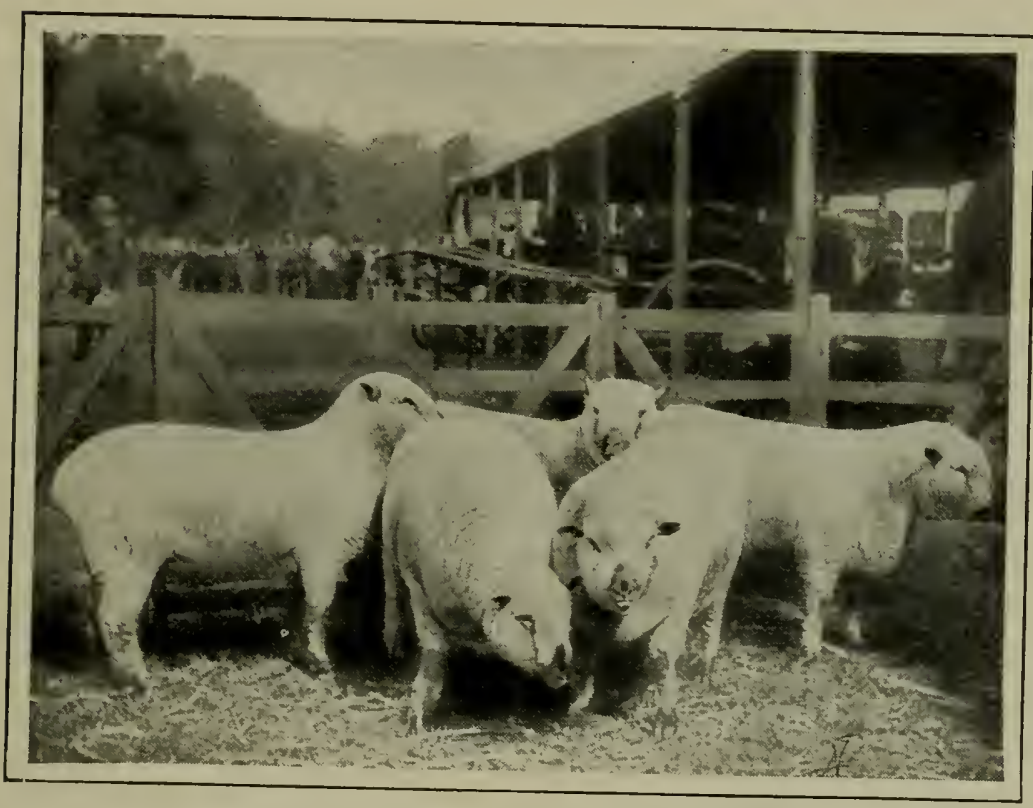

AT A ROYAL ENGLISH SHOW.

fed such protein-carrying foods as wheat bran, oilmeal, soy beans and alfalfa or clover hay.

Corn, (maize) is preeminently the best foodstuff for fattening sheep. It may be fed in very economical manner. In Ohio it is the practice to cut the corn when ripe, gathering it into large shocks containing from 144 to 256 hills. These shocks tightly bound about the tops keep out 
the weather and preserve the ears and blades very well. From the field the shocks are drawn direct to the feed yard, or to some large, dry feeding field, where the unhusked corn is strewn thinly over the ground. Here the sheep consume the ear's with little or no waste, trimming off the blades also. If this practice of feeding shock corn is now supplemented by supplying racks filled with clover or alfalfa hay the sheep are as well provided for as need be.

Sheep consume more food than steers, weight for weight of animals being compared and also make slightly greater gains for food consumed. In general sheep will consume about one-fourth more than steer's.

There would thus seem to be considerable advantage in feeding sheep over feeding cattle, when gains are considered and also fleeces secured, were it not that death losses are higher among sheep and also prices fluctuate considerably, sometimes feeders being relatively high in the fall and ripe sheep low in the spring.

The correct management of the sheep feeding yard is simple. There should be provided wind breaks. It is an old saying that "the pig an see the wind" and the sheep can certainly feel it through its thick coat. Sometimes these windbreaks are formed by long sheds, sometimes by high fences, made tight, and sometimes they are of natural timber and brush. Some of the best sheep the writer has ever seen fed were fed in the old fashioned way on shock corn, in a blue-grass pasture that had been allowed to grow up very high and thick, and where open 
glades mere interspersed with thickets of hazel, oak and hickory. In this primitive solitude the sheep found shelter and sustenance, feeding on shock corn strewn in the open places where the wind could not reach them.

Water must be abundant and good and very accessible. Sheep will not thrive if they must go far for their drink.

It is a good plan to provide wide, flat-bottomed troughs in which may be fed husked ear corn, since it will not all the season be practicable to feed shock corn. If the sheep have their teeth ther will shell the ear corn so readily that it is not worth while shelling it for them.

'The hay racks are best in shelter of sheds so that the hay cannot become wet with rains. And if there is room so that all can be sheltered from soaking storms all the better. Dry cold and snow will not hurt but wet is a serious setback.

Many sheep feeders rely upon self-feeders for shelled corn for the finishing of the sheep. These are usually large bins, holding 20 to 100 bushels each, with troughs on either side into which the corn descends slowly. There seems less objection to the use of the self-feeder for mature sheep than for lambs. The writer believes, however, that the greater profit comes from regular feeding in troughs of rations a little under the appetites of the sheep.

$A$ better and safer self-feeder is the self feeding corn crib. This is built with a capacity of hundreds or thousands of bushels, with a large trough at the side into which corn descends. 
Sheep shell this corn at their will and the cobs are thrown out as they gather.

Sheep ought to gain on feed from one to four pounds per week, depending on their condition and the stage of feeding. The gains are most rapid just before approaching ripeness.

Death losses in feeding mature sheep should be slightly less than in feeding lambs. Naturally gains are less since there is not opportunity for much growth along with fattening. The writer once made a gain of $45 \mathrm{lbs}$. with lambs in the barn while his wether's outside, very well fed, gained $20 \mathrm{lbs}$. The wethers consumed more corn than the lambs but had no wheat bran which the lambs received.

Sheep will consume better than lambs various coar'se fodders. Soy bean straw they relish, if it is not weather damaged, and bean and pea straw. When only a maintenance ration is fed it may consist largely of these fodders, with a trifle of grain to keep up the weight.

While in the regions west of the Missouri sheep feeding is carried on in this rather primitive fashion, in Michigan and Ohio it has progressed further toward a right solution of the problem. The writer has a neighbor who has fed sheep for many years. This neighbor, Chas. Bales of Madison Co., Ohio, formerly fed in open yards protected only by high fences. In these yards he fed with shock corn, using self feeders toward the latter part of the period. He was able to get a gain of about 30 pounds, using the best class of Montana feeders.

Later he built barns and sheds in which he 


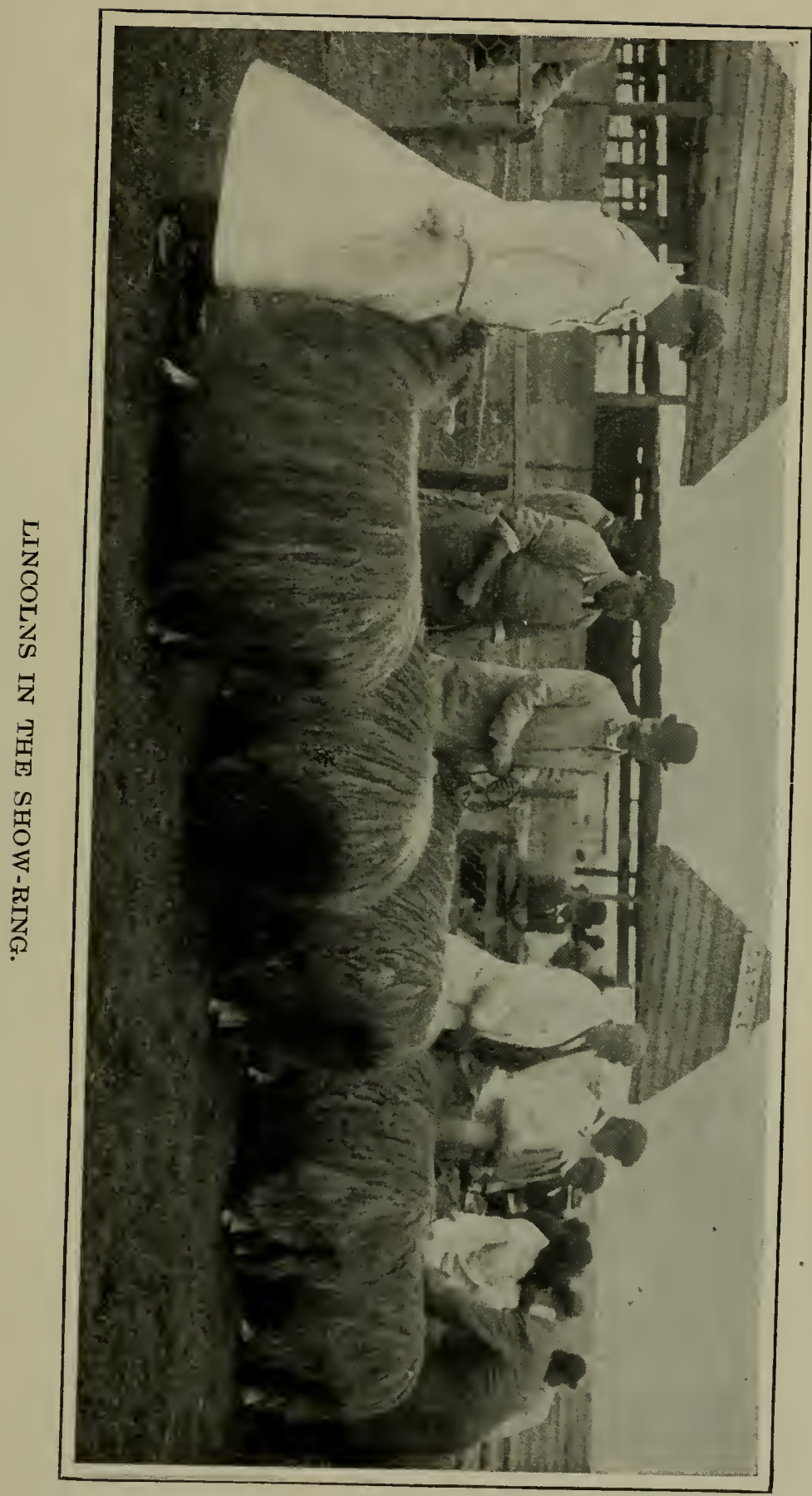



fed clover and alfalfa hay. Continuing his grain feeding in much the same manner he was able to increase his average gain so that 1,000 sheep weighing when they went into the yard $110 \mathrm{lbs}$. average increased to a weight of $156 \mathrm{lbs}$. besides shearing a fleece of 10 pounds. At the same time he cut down his death losses to 2 sheep from 1,200 one year and again to 6 from 1,200. He attributes the lighter losses to the fact of the sheep being more comfortable, thus eating with more regularity, and not injuring their digestions by sudden overloading with grain. He now believes that the self-feeders should be under cover and only the shock corn fed in yards.

This man makes a practice of saving the late summer growth of blue-grass on large pastures, on which the sheep are turned in October or November. On these pastures they remain until Christmas or sometimes till February if the season is suitable, having also racks filled with ciover or alfalfa hay. They then go to the yards for the final feeding, going to market, shorn, in May.

He believes that the secret of success in feeding wethers is to buy the best, using those with a Cotswold or Lincoln cross if obtainable, and to keep them stuffed at all times full of grass or clover or alfalfa hay. He finds that by this method they consume less corn and do not suffer from indigestion from the result of too much grain.

He does not turn the sheep to pasture until such time as danger from infection by intestinal parasites is past. 


\section{CHAPTER X.}

\section{THF IDISEASES OF SHFEP.}

AILMENTS IN GENERAL.

The writer is sure that sooner or later the reader will feel a sudden need of knowledge of sheep diseases and the remedies therefor. Thus at the risk of duplicating a good deal that has been said elsewhere, he devotes this chapter specifically to sheep diseases.

At the outset let me say that to the novice, and sometimes to the professional, it is very difficult oftentimes to say just what ails a sick sheep. Diseases may, however, be divided into three principal classes.

First, there may be some external parasite, as the tick, louse, scab or foot rot (which is in a sense an external disease.)

Second, there may be some form of internal parasitism. 'This may be worms in the stomach or intestines, in the throat or lungs, or encysted worms making a bladder in the brain. And one or another of these internal parasites is the cause of most of the sickness among sheep.

Last, there may be some derangement of the digestion due to improper feeding, no feeding 
at all, or gorging with grain. And in some regions, among the class of sheepmen who feed sleep in winter, nearly all diseases are of this origin.

Now as to chance of cure. For external parasites cure is easy and cheap. For scab, lice, and ticks there is the dipping bath, and this has been carefully explained in another place. Foot-rot is also of rather easy treatment.

These things are matters requiring timely and prompt treatment and are no cause for alarm whatever except as scab breaks out in the winter time in the middle of the feeding season, when it is costly to dip and the sheep have serious set-back therefrom. Indeed it is not just proper to class these external parasites as diseases, any more than fleas on a dog's back, though they produce disease if left unchecked.

The matter of internal parasites is much more serious. Nine-tenths of all the troubles of sheep east of the Missouri river are caused by some form or other of these plagues, or by a combination of them. We will presently give to them some attention in detail.

Derangements of the digestion, caused by too much or too little food, or by food of improper quality, are often hard to diagnose. For example, recently a neighbor of the writer came to him for advice. His wethers suffered from some brain disorder, they turned around and around in small circles, acting stupefied; they lingered a few days and died. These sheep had come from the same range in Montana. The writer promptly diagnosed the disease as gid 
or turn sickness caused by the encysted parasites called Taenia Coenurus. This worm is the fruit of a tape worm that infests dogs or wolves. The eggs pass from the dogs $\mathrm{Ol}^{\circ}$ wolves and are taken in by the sheep on the grass or in their drinking water. They hatch within the sheep and the young worms pierce the walls of the stomach, gaining the blood where they travel until they reach the brain, where they undergo a change, developing heads and making large bladders in which to live. It is necessary that the sheep should die after these cysts have reached a certain stage of development so that some dog, fox or wolf may feed upon the dead sheep's head and thus take into its own system the parasites which become established there as regular tape worms. Thus the round is continued. The tape worm within the $\operatorname{dog}^{\circ}$ or wolf reinfects the grass, the sheep become affected and die to infect more dogs (if there are any). Now the way this hydatid affects sheep is by pressing upon the brain substance and absorbing it until the nervous system is quite deranged, the sheep is stupid, it turns steadily round and round, always the same way, neglects food and dies.

The disease is somewhat prevalent in England and Scotland some years but is probably rare in America, at least in a rather long experience the writer is not sure that he has ever seen an instance of it, but from his book lore he advised his neighbor to dissect the next ailing sheep and look for the brain bladder worm or hydatid. 'The neighbor obeyed, but no brain 
disease was found. Another neighbor sent word to the afflicted one to cease feeding millet hay full of seed which he did and lost no more sheep, having lost some 30 before. Thus there was a clear case of deranged digestion deceiving one by the symptoms resembling those of brain parasitism.

The writer has seen other instances of deranged digestion that in the last stages gave symptoms very like the ones described.

Now a word about true "turn sickness." It is sometimes possible to cure the disease by locating the place in the brain where the bladder is formed and cutting through the skull and destroying the parasite by puncturing the sac that holds it. Recovery sometimes follows this operation, it is said. And in Scotland it is reported that some shepherds have such skill that they can push a sharp wire up the nostril till it locates and punctures the bladder in the brain. This is an interesting and astounding fact, if true. In practice, in America, where sheep are plenty and veterinarians of the finest skill in sheep diseases are costly to employ for such cases, it is best to kill the sheep for mutton (which is not hurt by the brain hydatid in the earlier stages), feed the head to the fire, and not to dogs and get some new sheep. It is a safe rule never to allow a dog or wolf to devour a sheep's head at any time. And dogs about the place may well be treated for tape worms. Dr. Rushworth thus prescribes for tape worms in dogs: "The dog to be treated should not be fed for at least twelve hours before re- 
ceiving the medicine but it can be allowed all the water it chooses. The evening before administering the worm medicine a dose of castor oil is advisable; for large dogs the dose is three tablespoonfuls. Then in the morning take of kamala 3 drachms, gruel 1 ounce, mix and give as a dose. With a medium sized dog two drachms of kamala will be sufficient. This is a very effective taeniacide."

As to the cure of disorders of sheep caused by overfeeding in the barn or feed lot. Cases will occur in the best regulated barns, not very many when things are carefully done, but always some. The writer and his brother's and neighbors have lost hundreds of sheep and lambs in this manner and tried many reputed remedies. He does not now believe he has ever benefited a sick sheep by medicine or treatment when the cause was due to serious derangement of digestion. Death is almost sure to follow no matter what you may do. If there is virtue in any thing it is in simply taking the sheep away from all grain whatever and letting it alone. If there is not too much internal disorder this will suffice but in ninety-nine cases out of a hundred when the sheep is sick enough to be very noticeable it will die no matter what you may do. So prevention, not remedy is the rule for disorder's of the digestion. These cases come from gorging with grain and there is probably some toxic poison formed, for in many instances where the writer has made post-mortem examinations of afflicted sheep immediately after death no morbid condition was apparent save a slight inflam- 
mation of some part of the intestinal tract, and sometimes even this was not in evidence.

Disorders of the bladder causing stoppage of the urine are caused by the deposit of limy substances in the bladder, which become washed into the urethra where they lodge, causing inflammation, stoppage of the urine, a period of suffering accompanied with great distension of the bladder, then death.

The reason for this disorder seems to be in some instances the eating of too many mangels rich in lime, the eating of too much salt, or the drinking of water too "hard" with lime. The worst instance that ever came under the writer's observation was in his own feeding barns where he had a great store of oat hay, put up so very moist that to save it, it was liberally sprinkled with salt. The salt was greatly in excess of the needs of the animals and made them consume much more water than they otherwise would. Very many of the wether lambs became afflicted with this distressing malady and many remedies were attempted to save them. Some few may have been benefited, though the writer doubts it. It is recommended to cut off the vermiform appendage in the end of the penis, and to slit the penis, opening the urethra, to free it from limy substances that obstruct. The writer advises prevention, and in his own experience with thousands of sheep and lambs under observation fed by his brothers for some years, good plain practice, using the same water supply, has resulted in not one instance of "water belly." 'The writer has 
been informed of other instances where oat hay had seemingly caused this disorder without the accompaniment of an overdose of salt.

The use of clover or alfalfa hay with corn silage in not too great quantity and corn, with oats or bran if desired, will not cause this disorder in one instance in thousands.

This is not a treatise on starvation, but it may be as well to drop here a hint that sheep that have been starved near to death for some time are not usually profitable animals to buy, since they take a long time to recover and many will die in the process unless great care is used in building them up again. The writer has known instances of famishing sheep being bought for a few cents each on some dried-up and overstocked range, shipped to other more fruitful ranges distant some ways and there turned out on good grass. They died rapidly, however, and continued to die for some time after being placed on the good feed.

IMPORTANCE OF POST-MORTEM DISSECTION.

The novice in sheep breeding and feeding, or the old hand for that matter, should take frequent opportunity of post-mortem examination of a sheep recently dead, seeking to see whether the cause of death is from disordered digestion or parasitic infection. It is useless to dissect a sheep that has been dead for some days and even after the lapse of a few hours there will often be misleading appearances, as of blood settling in one part or another, that will cause him to form very curious conclusions as to the 
cause of death and miss the real cause entirely. It would be amusing if it was not so annoying to read the letters from sheep owners attempting to describe the symptoms of their sick sheep and the results found after their making crude post-mortem examination.

Let us rest the case here; that only careful regular and judicious feeding will prevent death in the barn and feed lot and that medication for "water belly" or retention of urine and for serious indigestion has never yet proved of use. The fact is that the sheep suffering from slight indigestion is not readily detected among hundreds, and when its case is obvious it is too far gone generally to be helped by any known treatment whaterer.

\section{OTHER DISEASES OF SHEEP.}

Of a long list of diseases that sheep may sometimes be afflicted with, such as rheumatism, apoplexy, goitre, pining, humping, erysipelas, actinomycosis, tetanus, rabies, sheep pox, and a lot of other diseases usually catalogued, the writer has seldom seen an instance in his own flocks and if he had seen it would have felt powerless to help, with all the knowledge of specialists available. Sheep are said to suffer sometimes from black leg but it is rarely if ever reported in America, and in England, on the extremely fertile pastures of Kent, sheep suffer from anthrax. This disease is rare indeed in America among sheep.

Sheep do not suffer from tuberculosis, at 
least the disease is exceedingly rare among them in America or elsewhere.

In truth, of the long list of diseases usually catalogued as occurring in sheep the shepherd will not in his lifetime observe more than one or two, always excepting the diseases that come from internal or external parasites, from unwise feeding and from garget of the udder.

It is wise, therefore, to study carefully the question of the internal parasite and to learn ways of management that will avoid them. This learned all the long catalogue of diseases may repose serenely upon the library shelf, since the occurrence of an instance of one of them in the flock will be of the rarest.

\section{GARGET OR MAMMITIS.}

This is a disease that affects the udders of the very best and largest milking ewes, preferring those that are best bred and most coddled. The symptoms are a hard, distended udder, from which a changed sort of watery milk may be drawn, which often becomes streaked with blood and sometimes with pus. The flesh of the udder is often red or purple and upon pressure can be dented with the hand. The exe has fever and distress, milk secretion ceases, the udder mortifies and if the ewe lives long enough it sloughs off, leaving a sore slow to heal. In mild cases the symptoms are much less severe and the ewe soon recovers, losing perhaps the use of one quarter of her udder.

One of the causes that led the author to attempt this work was his despair of finding light 
on this and some other subjects in any existent book that had come to his notice. The causes usually assigned to the production of garget are lying on the cold ground, bunting by lambs or from having too much milk for the lamb to take clean. Doubtless all these things are evils, but the writer is convinced that the cause of garget is something quite apart from any one of them.

Probably there are two forms of garget, caused by different things and running different courses. Too much milk in the udder caused by the death or removal of a lamb, may cause caked bag and injure a portion of the udder, but that is a far different disease from the malignant garget that has often nearly broken the heart of the writer and of his younger brother, upon whose shoulders the mantle of shepherding on Woodland Farm has fallen. Indeed, excepting that the seat of the disease is in the udder, there are no symptoms in common with the two diseases. The writer has never seen a case of caked bag result fatally and but one or two of real garget recover; those after a long period of healing when the entire udder had sloughed off.

The writer believes that all the cases of malignant garget that have come under his observation have had a common cause, one not mentioned in the books, a sudden increase in the food of the erre, resulting in perhaps some morbid change in her blood that going to the udder, shortly after her lambing (the period has sometimes been as long perhaps as two weeks thereafter) and finding there some favorite germ has 
set up there the great and rapid destruction of live tissue that is seen. Doubtless the disease is caused by the multiplication of microbes coming from an introduced germ, equally doubtless the conditions must be right for the development of the germ. And the right conditions seem to be the derangement of the blood by too much food, especially by feeding with corn (maize).

A skilled veterinarian once related to the writer that he had never dissected the udder of a cow without finding therein, along with the milk ducts, germs of bacteria that he considered the agents that cause bovine garget. How the germ got there he could not tell. When conditions were right for the germ it multiplied and did its work of destruction. When conditions were right for the cow it remained, waiting. This is probably the explanation also in the case of the ewe.

Corn feeding of milking ewes has apparently induced most of the cases of malignant garget that have come under the writer's observation. Indeed he has seen a fine ewe, proud of her two beautiful lambs, with an udder like a Jersey cow, break into the lot of feeding lambs and gorge herself with corn; he has predicted at once that she would come down with garget, and has seen his sombre prediction verified; has had the sad task of trying to find mothers for the two worse than orphans and nursed the mother for weeks till at last, ghost of her former self, she went with the flock again, her udder com- 
pletely gone and only a partly healed surface to show where it had sloughed off.

The books prescribe for malignant garget hot water, camphor, applied externally, and epsom salts and iron and quinine taken internally. The writer after faithful efforts with hot water and all the rest of the remedies does not feel that he has ever in one instance even mitigated the horrors of this form of garget, so will not burden the reader with his recipes. Let the shepherd experiencing his first instance of trouble resolve that hereafter his ewes shall have the most gradual increase in feed after lambing; that they shall be given little corn and more bran, oats and early-cut clover or alfalfa hay, with roots or silage to make milk and that by this means he can prevent future inflictions of this nature.

For the simpler form of caked bag, however, hot water applications are doubtless good, with rubbings of camphor and belladonna, and some have recommended counter irritants like kerosene oil. This form will never occur either if the shepherd will keep the ewe milked out after lambing, and perhaps sometimes just before lambing if she is a wonderful milker, and will feed right taking care also at weaning time.

GRUBS IN THE HEAD.

Most of the old sheep books have chapters on this disease. It seems therefore the duty of the writer to speak of it also though he must confess that his practical experience with the pest 
has been very small. This may be because his flocks have almost always had shade of dark barn basements in which to lie during the heat of the day, conditions not conducive to the deposition of the eggs that hatching in the nostrils of the sheep crawl up into the sinuses of the nose and form the mature grubs. It may be, also, that well nourished sheep the more easily repel the grubs, or endure them with least inconvenience.

There is no cure for grubs, once they are established. They can not crawl into the brain of the sheep. They will come out of their own accord in due time. They change into a fly that in turn lays eggs for more grubs. You cannot do anything except to feed well the sheep. "Grub in the belly is a cure for grub in the head" is an old saying. Tar on the noses will let the sheep eat in comfort; once shepherds bored holes in logs and put salt in the bottom of the holes and pine tar around them. Sheep eating the salt got the tar. It needed replenishing daily, or oftener. Easier is the darkened shed for the sheep to lie in.

\section{LIVER FLUKE. - "THE ROT."}

This terrible disease has caused in the past great havoc in the old world. It is less prevalent there since the underdraining of their lands. It was a parasitic disease; the parasite passing one stage of its life in the liver of the sheep, the other in the body of a snail. If there is no water for the snail (a water species is 
chosen) the flukes cannot propagate. There is very little if any of the disease in America.

NODULAR DISEASE.

This is the disease commonly called by butchers "knotty guts." It is characterized by small tumors on the intestines, the tumors filled with a greenish cheesy substance. The disease is caused by a small worm, about an inch long, called oesophagostoma columbianum. The worm thrives in spite of its name. This worm seems a distinctly American species, inhabiting deer, goats and sheep, possibly rabbits. What it does to the sheep is to interfere with the digestion and assimilation of food. It works its way gradually into a flock and brings ruin to it. There is said to be no cure. Its progress is usually slow and it takes years to kill a sheep, as a rule. The way of spreading is by infecting the soil and grass through the excrements of the afflicted sheep. Therefore when sheep are so managed that lambs do not graze much behind their mothers they will not become affected. Presumably the contamination of the soil will not last longer than one year. This point we hope will be demonstrated by our national or state experiment stations before long. It is a vital necessity to know that of both the nodular disease and the stomach worm. Thus it is evident that a healthy flock can be produced by not intermixing the infection free young sheep with the infected older ones, and fattening and by marketing the older ones as fast as practicable. Little or nothing in the way of medica- 
tion can be done to cure the afflicted sheep. Prevention of the disease by right treatment of the young ones is the thing to be aimed at.

TAPE WORMS.

T'here are occasionally outbreaks of disease caused by tape worms. Montana and the Dakotas have suffered from these outbreaks, also various regions in the Eastern states. The writer has never observed a case of this kind upon the farm occupied by himself and his brothers and attributes this freedom from infection in part at least to the free feeding of pumpkins in the fall of almost every year. Pumpkin seeds are well known vermifuges of great value.

The tape worm of sheep, tænia expansa, varies in length from three to six yards. It is from one twenty-fifth of an inch in breadth at the head to one-half an inch at the tail. In appearance it is a dull white. It causes scouring, bloodlessness, white skin, emaciation, weakness and sometimes death.

Treatment should be given to each one of the affected flock. Prepare them for treatment by fasting for 12 hours. After being treated they should be confined for 24 hours so that the segments of tape worm expelled will not be scattered over the fields, to further infect them. The sheep should after treatment has been deemed satisfactory be put on clean fresh ground.

Dr. Rushworth always prescribes kamala for tape worms The dose is three drachms mixed 
well in three ounces of linseed gruel, this dose for adult sheep. Lambs will require from one to two drachms, according to their size.

Any medicine administered to a sheep should be given with the sheep standing in a natural position, with its head raised not too high, and given slowly, so that it may pass at once into the fourth stomach. If it passes into the paunch it will probably not do much good.

If the kamala does not prove effective Rushworth advises giving ethereal extract of male shield fern, one drachm castor oil, four ounces, mix and give as a dose to mature sheep. Lambs can have from one to three-fourths of this dose.

A tonic is then prescribed, consisting of salt, 2 pounds, epsom salts, 1 pound, sulphate of iron, one-half pound, powdered gentian, one half pound, nitrate of potash, 4 ounces. This is to be mixed together and fed to 100 sheep, in oats, bran or other feed. The writer believes good feed and change of pasture will make much tonic unnecessary.

HUSK, HOOSE OR PARASITIC BRONCHITIS.

There is a minute parasitic worm called Strongylus filaria that inhabits the bronchial tubes, causing the animals to cough and run at the nose, sometimes bringing death. In the opinion of the writer this is not a very prevalent disease in America, fortunately. The remedy is thought to be to fumigate with sulphur. The writer has tried the remedy and though the lambs treated did not have the disease for which he treated them they mostly sur- 
vived the operation What they had, and what most coughing, emaciated lambs have, is a related parasite, of far more import to us all, the dreaded stomach worm.

THE STOMACH WORM.

This little worm is but $3 / 4$ of an inch long and about as thick as a hair. It lives in the fourth stomach and especially afflicts lambs. It causes the diseases (or symptoms, rather) of "paper skin," "black scours," "lamb cholera" and so on. It attacks lambs at any age after they begin to nibble grass until cool weather comes in the fall. It is the smallest parasite yet mentioned in this list of diseases and has wrought a hundred times the havoc that these have all together It has devastated whole regions so that the sheep industry has been given up to them and men have taken to breeding swine. The stomach worm is responsible for gullied hillsides, abandoned farms, and boys leaving the farm. It is not a new pest but in olden time when sheep suffered from it men did not know the cause. Many years ago it swept over Ohio, decimating the Merino flocks, and over all the states of the corn belt. Then no remedy was known, nor was it understood whence came infection or how immunity could be had. Now we know all this and the stomach worm has lost its terrors to the intelligent and watchful shepherd.

This fourth stomach of the sheep is just where the intestines attach and where an important part of the digestion takes place. When it is 
filled with these tiny worms digestion is wonderfully disturbed and the lamb loses tone, the wool appears dead, the skin loses its pinkness, the appetite is deranged. The lamb may scour and may be constipated. It eats earth or rotten wood, in the latter stages of the disease. There may come a dropsical swelling beneath the under jaw. This is not a disease, only a symptom of the disease.

Depend upon it, if it is May, or from then till October, and your lambs are droopy, languid, their wool dead looking, their skins chalky, they have stomach worms. Just catch one and kill it, dissect it at once and examine the fourth stomach with care. You will surely see there the little writhing serpents that do the mischief.

These worms inhabit old sheep too, but do not do them so much harm. The life history is like this: the worms become mature in the body of the older sheep and pass out, laden with eggs about to hatch. The little worms do something, we do not know what, to get back into the sheep again. Probably they crawl up a little way on the grass. The lambs come along and nibbling close on tender grass where the ewes' excrements have been dropped take in the worms They mature in the lamb and raise havoc there as we have said.

Now cold weather either numbs or destroys these worms so that there is no danger of infection in winter, late fall or early spring.

Elsewhere, in management, the prevention of stomach worms is described. Here we will concern ourselves with the cure of afflicted lambs. 
The writer has dosed hundreds. For a number of years he has, on the same farm, had no cases to doctor. Moral : there is something in management. But there is something in cure also. Therefore the writer appends parts of bulletin of the U. S. Bureau of Animal Industry prepared by B. H. Ransom, March 1907. The writer has faith in the gasoline treatment and was the first man in America to administer it. His brother has had better success with carbolic acid than coal tar creosote using 12 drops for a mature sheep, given in milk. The bulletin follows:

The stomach worm of sheep, known to zoologists as Haemonchus contortus, is generally recognized as one of the most serious pests with which the sheep raiser has to contend. Sheep of all ages are subject to infection, and cattle and goats as well as various wild ruminants may also harbor the parasite. The most serious effects of stomach-worm infection are seen in lambs, while full-grown sheep, although heavily infested, may show no apparent symptoms of disease. It is from these, however, through the medium of the pasture, that the lambs become infected.

\section{SYMPTOMS AND DIAGNOSIS.}

Among the symptoms which have been described for stomach-worm disease probably the most frequent are anemia, loss of flesh, general weakness, dullness, capricious appetite, thirst, and diarrhea. The anemic condition is seen in the paleness of the skin and mucous membranes 
of the mouth and eye, and in the watery swellings which often develop under the lower jaw. A more certain diagnosis may be made by killing one of the flock and opening the fourth stomach. The contents of the fourth stomach are allowed to settle gently, and by carefully watching the liquid the parasites, if present in any considerable numbers, will be seen actively wriggling about like little snakes from one-half to $11 / 4$ inches long and about as thick as an ordinary pin.

\section{LIFE HISTORY OF THE STOMACH WORM.}

The worms in the stomach produce eggs of microscopic size, which pass out of the body in the droppings and are thus scattered broadcast over the pasture. If the temperature is above $40^{\circ}$ to $50^{\circ} \mathrm{F}$. the eggs hatch out, requiring from a few hours to two weeks, according as the temperature is high or low. When the temperature is below $40^{\circ} \mathrm{F}$. the eggs remain dormant, and in this condition may retain their vitality for two or three months, afterwards hatching out if the weather becomes warmer. Freezing or drying soon kills the unhatched eggs. The tiny worm which hatches from the egg feeds upon the organic matter in the manure, and grows until it is nearly one-thirtieth of an inch in length. Further development then ceases until the worm is swallowed by a sheep or other ruminant, after which it again begins to grow, and reaches maturity in the fourth stomach of its host in two to three weeks. The chances of the young worms being swallowed are greatly 
increased by the fact that they crawl up blades of grass whenever sufficient inoisture-such as dew, rain, or fog-is present, provided also that the temperature is above $40^{\circ} \mathrm{F}$. When the temperature is below $40^{\circ} \mathrm{F}$. the worms are inactive.

The young worms which have reached the stage when they are ready to be taken into the body are greatly resistant to cold and dryness; they will stand repeated freezing, and have been kept in a dried condition for thirty-five days, afterwards reviving when moisture was added. At a temperature of about $70^{\circ} \mathrm{F}$. young worms have been kept alive for as long as six months, and the infection in inclosures (near Washington, D. C.) which has been pastured by infested sheep did not die out in over seven months, including the winter, the inclosures having been left vacant from October 25 to June 16. It is uncertain whether infection in fields from which sheep have been removed will die out more rapidly during warm weather or during cold weather; experiments on this point are under way, but have not been sufficiently completed for definite statements to be made. It is, however, safe to say that a field which has had no sheep, cattle, or goats upon it for a rear will be practically free from infection, and fields which have had no sheep or other ruminants upon them following cultivation may also be safely used. The time required for a clean pasture to become infectious after infested sheep are placed upon it depends upon the temperature; that is, the field does not become infectious until the eggs of the parasites contained 
in the droppings of the sheep have hatched out and the young worms have developed to the final larval stage, and the rapidity of this development depends upon the temperature. It may be stated here that neither the eggs nor the newly hatched worms are infectious and only those worms which have reached the final larval stage are able to continue their development when swallowed. This final larval stage is reached in three to four days after the eggs have passed out of the body of the host if the temperature remains constantly at about $95^{\circ} \mathrm{F}$. At $70^{\circ} \mathrm{F}$., six to fourteen days are required, and at $46^{\circ}$ to $57^{\circ} \mathrm{F}$, aggregating about $50^{\circ} \mathrm{F}$., three to four weeks are ncessary for the eggs to hatch and the young worms to develop to the infectious stage. At temperatures below $40^{\circ} \mathrm{F}$., as already stated, the eggs remain dormant.

METHODS OF PREVENTING INFECTION.

It is evident from the foregoing statements that in the northern part of the United States, under usual climatic conditions, infested and non-infested sheep may be placed together in clean fields the last of October or first of November and kept there until March or even later, according to the weather, with little or no danger of the non-infested sheep becoming infected. If moved then to another clean field they may remain there nearly the entire month of April before there is danger of infection. From the 1st of May on through the summer the pastures become infectious much more quickly after infested sheep are placed upon them, and 
during May it would be necessary to move the sheep at the end of every two weeks, in June at the end of every ten days, and in July and August at the end of each week, in order to prevent the non-infested sheep from becoming infected from the worms present in the rest of the flock. After the 1st of September the period may again be lengthened. This method of preventing infection in lambs would require a considerable number of small pastures or subdivisions of large pastures, and in many instances could not be profitably employed, but in cases where it could be used it would undoubtedly prove very effective. By the time the next lamb crop appeared the pastures used the year before would have remained vacant long enough for the infection to have disappeared, and would consequently again be ready for use. By continuing this rotation from year to year, not only would each crop of lambs be protected from infection, but as reinfection of the infested ewe flock is prevented at the same time, the parasite would in a few years be entirely eradicated from the flock and pastures.

If such frequent rotation is not possible or practicable, a smaller number of pastures may be utilized, after the ewe flock has been treated with vermifuges. The treatment may be given either before or after the birth of the lambs. If before, the ewes should be treated before pregnancy is too far advanced, in order to avoid possible bad results from the handling necessary in treatment. Probably the best time for treatment is late in the fall or early in the winter. 
The treated sheep should be placed immediately on clean pasture in order to avoid reinfection. The object of treating the ewes is to get rid of the worms with which they are infested, and thus remove the source from which the pasture becomes contaminated. If it were possible by treatment to free the old sheep entirely from stomach worms, it is evident that the lambs would remain free from infection, provided, of course, that the flock were afterwards kept on clean pasture. Unfortunately, there is no vermifuge known which can always be depended upon to remove all of the worms, but it is possible to get rid of most of them and thus greatly reduce the amount of infection to which the lambs will be exposed.

Two other methods may be suggested by which lambs can be kept free from infection with stomach worms.

1. It is assumed that a large pasture is available which has had no sheep, goats, or cattle upon it for a year, if a permanent pasture, or since cultivation, if a seeded pasture. This pasture is subdivided into two by a double line of fence, and a drainage ditch is run along the alley between the two fences. At one end of the alley between the two subdivisions a small yard is constructed, communicating with each of the subdivisions by means of a gate. When the lambs are born they are placed in one of the subdivisions and the ewes are placed in the other. The small yard should be kept free of vegetation and must not drain into the lamb pasture. As often as necessary the lambs are 
allowed in the small yard with the ewes for suckling. The rest of the time the lambs and the ewes are kept separate in their respective pastures. By this arrangement the lambs are exposed to infection only while they are in the small yard, where they may become infected either by embryos of the stomach worm present on the manure-soiled skin of the infested ewe, or by embryos picked up from the ground which has been contaminated by the droppings of the ewes. The chances of infection from the skin of the ewe are so light that in practice this source of infection need not be considered. The danger of infection from the ground may be avoided by frequently removing the manure from the yard and keeping the surface sprinkled with lime and salt. The lambs and ewes will soon learn the way to their proper pastures, and after a few days little difficulty will be experienced in separating them each time after the lambs are through suckling.

2. Another plan which may be followed where the climatic conditions are suitable - that is, in regions where there is a cold winter season-is that of having the lambs born at a time of year when there will be no danger of their becoming infected during the suckling period, and weaning and separating them from the rest of the flock before the advent of warm weather. Under the usual climatic conditions of the State of Ohio, for instance, if the lambs are born in the latter part of October or the first of November they may remain with the ewes on fields which have not been previously occupied by 
sheep, goats or cattle within a year-or, if cultivated fields, since cultivation-until the following March without danger of becoming infected, since the eggs in the droppings of the infested ewes will not hatch out during this time of year because of the cold weather. The use of fields not previously occupied by sheep, goats, or cattle within a year, or since cultivation, is necessary, since otherwise the fields would be already infected with young worms which had hatched out and reached the infectious stage before the beginning of cold weather, and the lambs would consequently be liable to infection from picking up these young worms, which are not killed by cold weather after they have reached the final stage of larval development. When they are weaned the lambs must, of course, be placed on clean pasture, if they are to continue free from infection. With this method only two clean pastures are necessary, one in which the ewes and lambs are placed in the fall, and another for the lambs when they are weaned in March.

Unfortunately for this scheme, it is not always possible to have lambs born at the beginning of the winter season; but with additional clean pastures a modification of the foregoing method may be used in the case of lambs born toward the end of the winter or in the spring. In the northern United States lambs born the first of February for example, may be kept with their mothers in a clean field or pasture until the last of March, as in the case of those born at the beginning of winter, but un- 
like the latter they will not then be old enough to wean. Accordingly they are not separated from the rest of the flock, but the ewes and lambs are moved together to a second clean pasture April 1. May 1 they are moved to a third clean pasture, May 15 they are moved again, and finally the lambs are weaned June 1 at the age of four months, and moved by themselves to a clean pasture. In the case of lambs born the first of March and weaned the first of July three additional clean pastures would be required for use during the month of June, and with later lambs a still greater number of pastures would be necessary.

TREATMENT FOR STOMACH WORMS.

Among the remedies which may be used to remove stomach worms may be mentioned coaltar creosote, bluestone, and gasoline.

The animals to be treated should be deprived of feed for twelve to sixteen or even twentyfour hours before they are dosed, and in case bluestone is used should receive no water on the day they are dosed, either before or after dosing. In drenching, a long-necked bottle or a drenching tube may be used. In case a bottle is used the dose to be given may be first measured off, poured into the bottle, and the point marked on the outside of the bottle with a file, so that subsequent doses may be measured in the botthe itself. A simple form of drenching tube consists of a piece of rubber tubing about 3 feet long and one-half inch in diameter, with an ordinary tin funnel inserted in one end and a piece 
of brass or iron tubing 4 to 6 inches long and of suitable diameter inserted in the other end. In use the metal tube is placed in the animal's mouth between the back teeth, and the dose is poured into the funnel, which is either held by an assistant or fastened to a post. The flow of liquid through the tube is controlled by pinching the rubber tubing near the point of union with the metal tube. It is important not to raise the animal's head too high on account of the danger of the dose entering the lungs. The nose should not be raised higher than the level of the eyes. The animal may be dosed either standing on all fours or set upon its haunches. It has been found by experiment that if the dose is taken quietly most of it will pass directly to the fourth stomach when the animal is dosed in a standing position, and that when the animal is placed on its haunches only a part of the dose passes immediately to the fourth stomach. From this it is evident that the position on all fours is preferable, as more of the dose passes to the place where its action is required.

Great care should be used not only in dosing to avoid the entrance of the liquid into the lungs, but also in the preparation and administration of the remedy so that the solution may not be too strong or the dose too large.

\section{COAL-TAR CREOSOTE.}

Good results have been obtained from a single dose of a 1 per cent solution of coal-tar creosote. This solution is made by shaking together 1 ounce of coal-tar creosote and 99 ounces (6 
pints 3 ounces) of water. The doses of this 1 per cent mixture recommended by Stiles are as follows :

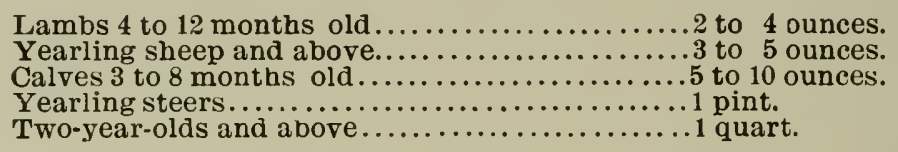

Serious objections to the use of coal-tar creosote have been found in that the substance known by this name varies considerably in composition and in that some trouble is often experienced in obtaining it in many parts of the country. Complaints have been made that the substance dispensed by some druggists as coaltar creosote has failed to give satisfactory results.

\section{BLUESTONE.}

Bluestone, or copper sulphate, has been extensively used in South Africa in the treatment of sheep for stomach worms and is recommended by the colonial veterinary surgeon of Cape Colony as the best and safest remedy. His directions are to take 1 pound avoirdupois of pure bluestone, powder it fine, and dissolve in nine and one-half United States gallons of warm water. It is better to first dissolve the bluestone in 2 to 4 quarts of boiling water, then add the remaining quantity in cold water, and mix thoroughly. This solution is given in the following-sized doses:

Lambs 3 months old........................... $3 / 4$ ounce.

Lambs 6 months old.............................11/2 ounces.

Sheep 12 months o1d................................21/2 ounces.

Sheep 18 months old................................ 3 ounces.

Sheep 24 months old................................ $3 \frac{11}{2}$ ounces.

In making up the solution only clear blue 
crystals of bluestone should be used. Bluestone with white patches or crusts should be rejected. It is especially important that the bluestone and water be accurately weighed and measured, and that the size of the dose be graduated according to the age of the sheep.

\section{GASOLINE.}

Gasoline is one of the most popular remedies for stomach worms which has been used in this country and has the particular advantage of being readily obtained. It is important to repeat the dose if the gasoline treatment is employed, and it is usual to administer the treatment on three successive days, as follows:

The evening before the first treatment is to be given the animals are shut up without feed or water and are dosed about 10 o'clock the next morning. Three hours later they are allowed feed and water, and at night they are again shut up without feed or water. The next morning the second dose is given, and the third morning the third dose, the treatment before and after dosing being the same in each case.

The sizes of the doses are as follows:

Lambs.

$1 / 4$ ounce.

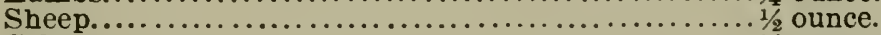

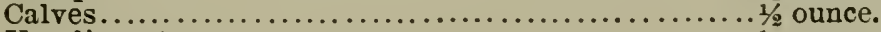

Yearling steers...................................

The dose for each animal is measured and mixed separately in linseed oil, milk, or flaxseed tea, and administered by means of a bottle or drenching tube. Gasoline should not be given in water.

OTHER REMEDIES.

Many other remedies in addition to those 
mentioned here have been used in the treatment of stomach worm disease with more or less success. Several of the coal tar dips on the market are recommended by the manufacturers for the treatment of worms, and the action of some of them is much the same as that of coal tar creosote.

The Department of Agriculture does not recommend the use of any particular proprietary remedy and as the action of some such agents is very uncertain it is suggested that, if it is desired to use them, they be used with caution and only in accordance with the printed directions on the package. Whatever remedy is used, it is wise to test it on two or three animals before the entire flock is dosed.

\section{START WITH A HEALTHY FLOCK.}

It may be that the reader has a flock of diseased sheep. He has had much trouble with stomach worms, or the nodular disease has invaded the flock, or he has bad losses from tapeworms. Shall he therefore go out of business?

That, indeed, may be his best course. To get rid of the diseased flock, first fattening the sheep as well as possible, and to let the land rest for two years will be quite sure to make the land clean, ready for a new flock. But there are certain objections to this course. First, he gets out of touch with the sheep industry, and that is bad. Then he begins to devote his land to other purposes and it is harder to again start with a flock. And there is the very real and practical difficulty that it is im- 
possible to be sure that the new flock is free from the enemies that led to the discarding of the old one.

The shepherd may take advantage of the fact that lambs are born healthy to start anew with a clean flock, even though his ewes were tainted. Infection will not come from the mother's milk, unless in rare instances from the fouling of her: udder. If she lias a clean bed there is small risk of that. If she is scouring she should not be put in the company of ewes devoted to this purpose.

These ewes should be bred as early as practicable, so that their lambs will come if possible in November, December or January. 'That is because in northern situations there is practically no danger of infection anywhere, indoors or out, in cold weather. Ewes and lambs should all be well fed to encourage a vigorous growth.

When warm weather begins to come in April the ewes should be confined rigidly to the barn and small yard. In that yard there should not be permitted to grow even a single weed or spear of grass. This rule must be absolute. The yard must be small and kept always perfectly clean. If it is not the lambs may nibble at some plant and from its lower lengths, or roots, imbibe the germs that we are seeking to avoid.

Nor should there be any feed thrown into the yard. Furthermore the hay racks should be kept clean and the water pure at all times.

As fast as ewes cease giving a good milk flow they should be removed to another pen and thus 
their contact removed, with a per cent of the danger.

When grass comes the lambs should be taken to a field where no sheep ran the previous year; where no sheep manure had been spread the previous year, and where no stream or pool could bring germs from some other flock. Once established there no other sheep should for an instant be permitted to mingle with them.

The ewes, if there is room on the farm, may be kept over for another crop of lambs, since it will take two crops to produce enough ewe lambs to make up their number. After that all that are not of this youthful blood and free from infection should be sold and the youngsters given possession.

At all times there should be this thought, "Has there been opportunity during the past year for any sheep to drop germs with their manure upon this land?' If the answer is yes, then do not permit the lambs and yearlings of the clean flock to graze upon that ground for an instant.

The extra cost of this method of producing a perfectly healthy ewe flock is almost nothing. A trifle of care, a constant thoughtfulness, a few hours labor and the result; a banishment of the torments that render 60 per cent of farm flocks in the corn belt diseased and comparatively un. profitable.

And having a healthy flock, absolutely without parasites, they will remain so if the germs are not brought in by something added to the flock. It is barely possible that rabbits may 
carry some of the same parasites that afflict sheep as also do goats and deer. Aside from them there are no other carriers of these germs so far as me know. Unfortunately we must purchase rams or else practice inbreeding. The writer is inclined to think that with strong, well bred, vigorous stock once secured it is wiser to inbreed for a time rather than to risk purchasing a new starter of germs with an uncertain ram. However, the ram himself may be put in quarantine on his arrival, permitted to associate with the flock only when he can be of use to it and at all other times have his own quarters, a grassy paddock with shed attached.

Thus, without giving a dose of medicine or applying to the soil any lime, salt, corrosive sublimate or iron sulphate, the farm secures clean pastures, stocked with clean sheep.

Following the thought of destroxing the parasites in the soil, as is frequently advised, by applications of lime, salt or chemicals, the writer would call to the attention of the reader the folly of the proposal. There is in an acre 43,560 square feet. Supposing that we desired to purify that soil to a depth of one foot, not an unreasonable depth, there is then to purify 43,560 cubic feet of soil. It mould take at least a pound of salt to destroy germ life in a cubic foot of soil; it is doubtful if that would suffice, so that about 21 tons of salt to the acre rould be required. Of lime probably two or three times as much would be needed, and when it comes to applying chemicals one had better halt, for he will have destroyed his land before he will have killed the 
germs; that much is sure. And why do this thing, when all these germs will perish (we believe) in one year unless they find their host, a sheep, deer or goat, in which to undergo part of their life cycle?

The writer is very glad to give credit to Dr. W. H. Dalrymple of Louisiana, for having performed by far the most useful series of experiments ever made in attempting to rid sheep of parasites in much the manner that he has described in the foregoing paragraphs. It is remarkable that a far Southern state should undertake a work fraught with so much import to men in the sheep growing regions further north, the explanation being of course that Dr. Dalrymple is a Scot. 


\section{CHAPTER XI.}

\section{THE ANGORA AND MILKING GOATS.}

It may not be out of place in this work to give a little information concerning the Angora goat, which is now becoming so well and favorably known.

Indeed the sudden arrival of the Angora into public appreciation and its very wide distribution will make inspiring chapters in the history of American live stock.

\section{THE ANGORA GOAT.}

While not meaning to wander far into the realms of goat lore yet a few words concerning this work. So late as 1897 the first large number of goats were sent from Texas to Iowa as an experiment in brush destruction, going to J. R. Standley. These goats "grubbed the land, brought in grass and boarded themselves, besides vielding a profit." Other shipments followed. They also were successful. Since that time goats have been introduced into every state and territory of the United States and into Alaska and the Hawaiian Islands. Usually they have accomplished their object; they have destroyed brush, and grass has followed 
in their footsteps. Now there is a demand for goats and inquiry concerning them. Several kinds of disappointments have followed the introduction of so-called "Angoras" into new neighborhoods. To answer some of the many questions arising in connection with this subject this chapter is written. Breeder's of Angora goats should have one of the following works, "New Industry, or Raising the Angora Goat and Mohair for profit," by Wm. L. Black of Texas; "Angora Goat Raising and Milch Goats," by George Fayette 'Thompson, or "The Angora Goat," by S. C. C. Schreiner (Longmans, Green \& Ċo.). Schreiner's work is a classic, a thing of beauty. Thompson is concise and practical, enthusiastic enough, and tells besides much about milking goats. Black is an earnest advocate and presents a great array of facts and examples of successful practice. I think he leaves out the failures and some of the difficulties.

Very extravagant things are claimed for Angora goats. It has been claimed that they will shear from six to eight pounds of mohair per year, worth-well, all sorts of prices from 75 cents to $\$ 8.00$. That was in the olden time. They have been claimed to be immune to all sickness, hardy as the common goat; that they will kill dogs and keep disease from among horses; that they would clear land of brush and make delicious mutton at the same time; that they were very prolific.

Now the simple truth is that the Angora goat is the most delicate, though the most beau- 


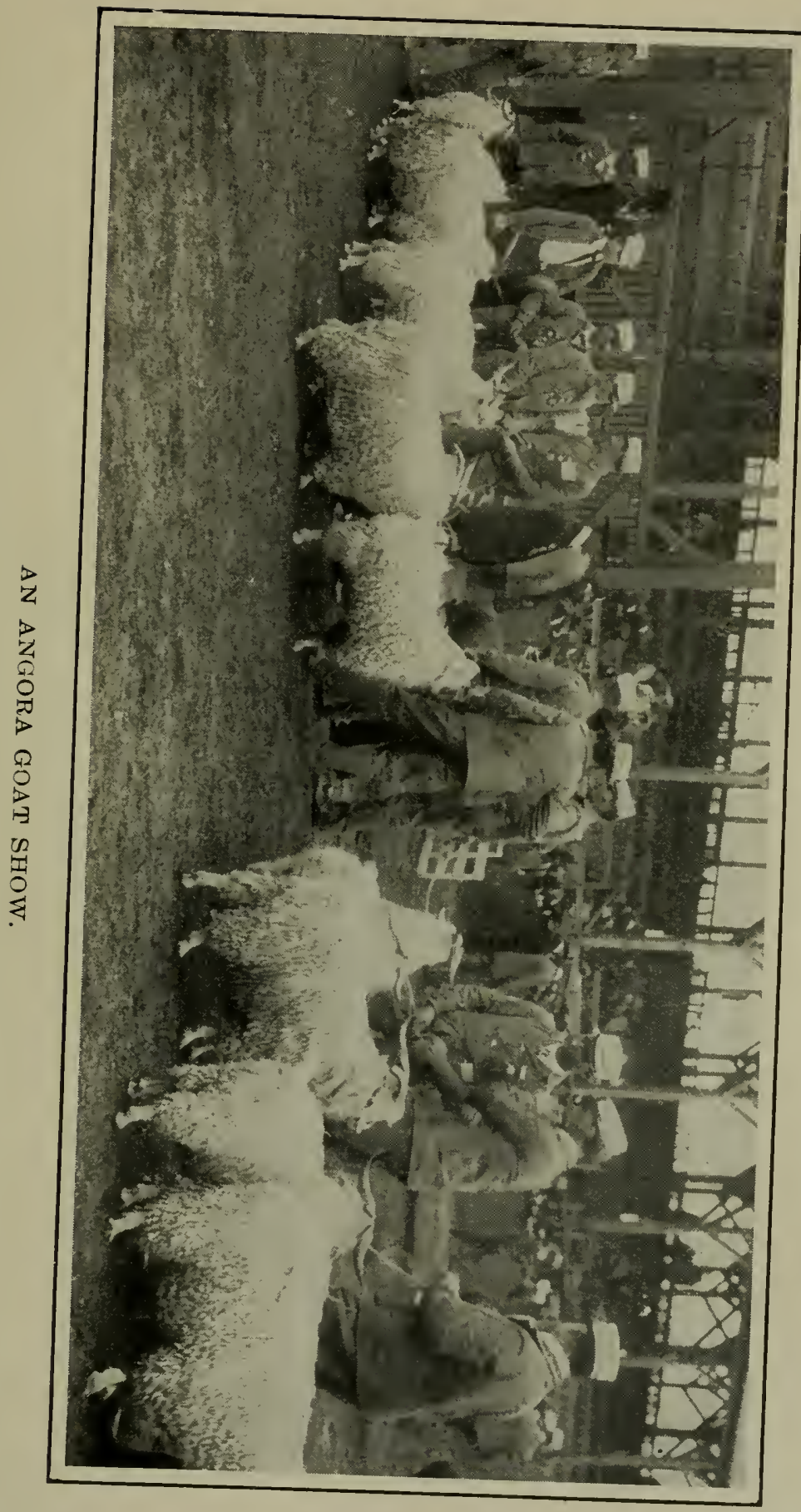



tiful goat known. It is troubled with all the diseases that afflict sheep, or most of them. It is not very prolific, nor are the kids very easily raised in a cold and wet climate. It is not dogproof, nor will it serve very well to keep dogs from sheep. It destroys brush effectually, if it can reach it, but should have some grass along with the brush to keep it in good order. And it shears a fleece of about 3 pounds that is worth from 7 to 40 cents per pound.

While the writer from his study of goats believes his characterizations true, yet he believes further that despite their delicacy Angoras can be profitably grown in every state in the Union, wherever there is rough, dry, brushy land, that they may readily be kept in health, and more readily than sheep, since they are in no danger from parasitic infection while browsing on trees, and that the quality of their fleeces may be so greatly increased by systematic breeding that the 7 -cent fleeces will become extinct and even the best fleeces will become more valuable.

Let us get at the history of the American Angora goat. The native home of the Angora is in Asiatic Turkey, on a high, dry and rather cold plateau. It may be that there is some peculiarity of the soil and climate of that region or some mental twist of the breeders there, since there are other animals found there that have the long silky hair that characterizes the true Angora. Cats from Angora have that quality, and dogs are said sometimes to possess it. The ancient history of the Angora is un- 
known. It has doubtless been the companion of man for countless ages and civilizations have existed upon the world far longer than we have been taught. This region of Angora was in the ancient days famed for the wonderful fabrics woven there, and the Angora goat furnished the fleece for these fabrics. Occasionally war or famine decimated the flocks, and at last the changes in industrial life hushed the looms of Angora and the industry of spinning the fabrics was transferred to England. Thereafter mohair became a regular export from Angora, and the quality of the product suffered at once. What was good enough to use at home became too good to sell abroad and the Angoras were crossed with a baser goat called the Kurd. It is thought that there is not now in the world a specimen of the true, ancient Angora. The loss has been in the fineness of the hair and the presence of more kemp, which is an under hair shorter and damaging to true mohair, because it will not take dye. It would seem from the studies of Mendel's law that it is most unlikely that the true and honorable blood of the old Angora is lost, for it is sure to reappear in its purity sooner or later, if it has not already, and can be fixed again, if it has not already been fixed, by proper matings.

In the beginning the Sultan of Turkey gave a few Angoras to Dr. Jas. B. Davis of South Carolina. Dr. Davis called them "Cashmeres," and for some years they were called by that name in America. though the Cashmere goat is quite distinct and of no great value in its pres- 
ent form and has never been bred pure in the United States, so far as the author knows. These goats throve fairly well, and following the custom of the times very great laudation was made of their virtues, among other things that they sheared from four to eight pounds, which sold from $\$ 6.00$ to $\$ 8.00$ per pound in Scotland. This, unfortunately, was an exaggeration of about $\$ 7.25$ per pound, but the goats meekly bore the obloquy as in the Israelitish days of old, meantime going merrily about their true mission, to subdue and replenish the earth!

When Dr. Davis had finished with his goats they were sold, and among the purchaseris was Col. Richard Peters, of Georgia. This man proved to be an Angora enthusiast and in turn sent specimens to Texas, California and other places.

It is significant that the Angora never became prominent anywhere except in Texas, California and Oregon until within comparatively recent years. There were several reasons for that. The warm, dry climates of the two states were peculiarly suited to the animals and land was cheap there and range limitless. Then there were found in Texas herds of common Mexican goats on which the Angoras could be crossed. This crossing was done on an extensive scale and in a short time there sprung into existence great flocks of grade Angora goats, larger and stronger than the pure-bred animals, but possessing a small amount of inferior hair. Further crossing greatly improved the hair, however, and it is not meant to suggest that this 
debasing blood has brought ruin or irretrievable loss. In truth, the added size and strength of the grades have been a help, and by the careful selection of bucks for a few generations wonders are worked in Angora grade fleeces.

This brings us (without mention of further interesting importations) down to the date of the recent exploitation of the Angora. Proved in 1897 to be unrivalled brush exterminator:s in Iowa, their fame spread, and Angoras have been sent in carload lots to most all the states and territories. When they have been good goats and given good care they have proved profitable. When they have been common goats, the result of indifferent grade sires on commion smooth Mexican goats, they have still proved excellent brush exterminators but have struck their owners with dismay when they had them sheared and tried to sell the fleeces.

Within very recent years, however, since the establishment of a record and flock book for the Angoras; with classes at fairs and new importations from Asia and Africa, there is a very great improvement coming over the Angora industry and it is only a question of time when good mohair will be abundant on the American market. When that time comes, curiously enough, it will be in greater demand than it is, now that it is rather scarce. Mohair is used in making plush for dress fabrics and yarns. It is the most durable of all fabrics, practically indestructible by wear. Most of the upholstery of railway cars in the United States is said to be made from mohair. 
What then could a breeder hope to reach in Angora goat breeding? By the use of right sires, for a series of years, by discarding from the fiock steadily the worst he ought in time to possess a flock shearing from 4 to 6 pounds of mohair, worth about 45 cents per pound at the present writing. That will pay well. A fleece of 2 to 3 pounds worth 20 cents per pound is discouraging.

It takes time, however, to breed out the common goat from the Angoras. To buy any large number of practically pure-bred goats is impossible in America. The breeder must have patience, persistence and the habit of extermination.

Now what of management? Newly arrived goats from the Southwest are tender and when turned on cold Eastern pastures may suffer considerably for a time. They need a dry shed, open to the south. To this they will come whenever it threatens rain. They may be fed there some dry forage, clover hay or whatever is available It is not usual to feed them grain, and much grain will cause the kids to be born with small vitality. The fence restraining them may be of woven wire and thus they are easily held in bounds. They must not be confined to too small a pasture else they will famish. Better let them take their time to the brush extermination and make a profit from them as you go along. They will feed upon the leaves of almost every species of tree and brush. if they can reach them. They will not do much in the way of girdling trees, though they will 
eat the bark from some varieties of trees. They do not much relish hickory. Green briars are dangerous because they sometimes catch and hold fast the little goats till they perish. These should be mown off with a brush scythe and then the goats will keep them down. They do not make a meal of any one article of diet but nibble a few leaves from one shrub, a few from another, then some weeds, some grass, more leaves and so on the day long. They will not thrive on brush alone. They will live well on grass alone but thrive better to have brush to mix with it. They require water. Laurel will poison them if they are given access to it when very hungry.

Angoras make good eating. Their flesh is called "venison", or "mutton," according to the state of their respective markets. The Angora does not have the overpowering odor of the common male goat. They are as dainty as deer in their habits. Offered for sale at our great market centers they sell for considerably less than sheep, 1 to 2 cents per pound less.

This condition may improve with time and the elimination of more of the common goat from their blood.

Angora goats are not heavy milkers and are not suitable for use as milking goats. Great excellence is seldom attained in two or three diverse lines of endeavor.

The beginner in goat raising in the East should fix in his mind a few facts. Angoras are not exceptions to the universal rule in the animal world that food is required for sustenance 
and growth. They are able, true, to eat foods that other animals neglect, but as a rule brushwood is not very nutritious and there ought to be some grass in connection. In winter time Angoras deprived of food suffer as sheep would. They can not subsist on coarse browse. They need bright straw, corn fodder, a very little grain. Then let them browse what they will. They absolutely must have abundant exercise to keep them in health. They love to take it by roaming about and browsing.

They must not be crowded. The shed should be roomy and airy and dry under foot. It is absolutely essential that they should have an abundance of fresh air. They are very dainty about what they eat and will not eat any forage that has been dropped underfoot. Their racks, therefore, should be so made as to hold the forage up. It is useless to lift hay or fodder from the floor or ground and put it again into the rack; they refuse it. They have the sensitive noses of rabbits.

Do not forget the dryness under foot. The yard must not be muddy, and if it becomes so, slightly raised walks of plank or rock should lead from the dry shed to the dry pasture outside. There should be abundant opportunity of entrance to the shed. It is best to leave the entire south side open, else some quarrelsome individuals will prevent the others from gaining ingress.

The period of gestation in the Angora is about 150 days. A buck will serve from 40 to 50 does. 
The buck should be managed as has been advised for sheep, though some breeders practice turning in about 5 bucks to the hundred does and leaving them, with the result that nearly all the kids come at one time. This may be a good practice if the breeder can manage them in that way.

The kids must not come before warm weather, After the leaves start in the spring is the proper time. The does should be sufficiently well nourished to be strong at kidding time, though one must not overdo this kindness, else the kids will come weak. Abundant exercise for the doe with sufficient food will make a successful kidding.

Angoras must have care and attention at kidding time, much more than ewes require. The little kids are delicate and can not endure cold or wet. They are not hardy and must not follow their mothers out to graze before they are six or eight weeks old. Should they attempt to follow they will become weary and lie down to rest and become lost. Therefore, they are kept in the corral and a board put up over which the mother must jump. When the kid can also jump out it may follow her.

A better scheme is the "bridge." This is an incline ending abruptly in the air, the high end at the corral side. The does jump up on this to go out and the weaklings run under where they can not get through Thus they are removed from danger of being stepped upon by their mothers or other does.

When the kid is born it should be placed with 
its mother in a small pen. Care should be taken not to handle it unnecessarily nor to rub it against other kids, else the mother may become confused by the odor, and she depends upon that entirely for her knowledge of her offspring. If it is inconvenient to have a pen for each doe, several may be confined to the one pen, placing their kids apart as far as possible. 'The kids are often "staked," that is tied by one leg with a strong cord in which is a swivel. The doe will always return to where she left the kid to seek for it. It is said that twice a day is often enough for the kids to suck. Should the doe disown her offspring she will own it again if confined with it and the kid assisted to suck for a few days.

The kids must not be exposed to cold or wet, as has been said. They are more delicate than lambs. Is not this a striking proof of the antiquity of the breed? For how many unnumbered centuries has it been under the fostering care of man! The common goat is the hardiest of domestic animals, and the most difficult to get profit from. The Angora, with its delicately beautiful fleece, has had this ruggedness sacrificed to the beauty and usefulness of its covering. As a rule the better bred the Angoras are, the nearer pure-bred, the more delicate they are. And yet, given right management, they are hardy enough. They endure tropic heats and semi-Arctic colds, but they must be dry, they must have air and exercise and food partly of browse and partly of grass.

We will not here go into the lange manage- 
ment of Angoras. Any one wishing to grow them in large numbers should make careful study in detail. He will find much information in the volumes previously mentioned in this chapter. Dry, hilly ranges are admirably adapted to Angora goat growing. They seem rather more expensive to manage than range sheep, especially at kidding time. It is not well to put more than 1,000 in a flock. An increase of 75 per cent is considered good. In small lots increases of 100 per cent are not unusual. The better bred Angoras are the fewer the pairs of twins born.

Angoras suffer sometimes from stomach worms, from foot rot and lice, from two sorts of scab (they are exempt from sheep scab), and probably from nodular disease. They have a disease of their own called "takosis," which makes them waste away giving them a tired feeling, accompanied with diarrhoea and cough. It was once believed that Angoras had no diseases; indeed like sheep in dry hilly regions they are practically exempt from disease, but when brought to damp countries with dense green grass their environment is so changed that they become infected in the same manner as sheep. The treatment for internal parasites is the same as for sheep. Good management in suitable locations will prevent disease in Angoras.

Where should Angoras be introduced? Not to arable farms. Sheep pay better there. But to hilly and brushy regions where it is not desired to encourage the growth of new timber, or 
where it is desired to clear away a part of the brush and replace it with grass. In Virginia, West Virginia, Pennsylvania, Kentucky and southern Ohio, in Tennessee and the hill regions south of there Angoras might exist by thousands with profit and advantage.

They should in all locations have provision made for feeding in winter, some dry corn fodder, oats and hay.

The difficulty in introducing Angoras to the region best for them is the character of many of the people living there. The careful reader will have realized ere this that Angora goat breeding is not adapted to a careless, lazy or indifferent man's habits. More than most animals, Angoras are dependent upon man for aid in infancy and help at intervals during life. Angoras are destroyed sometimes by dogs, though it is thought that with a number of wethers among them they are less subject to attack than sheep. The man who wishes to breed goats without care or attention from him had better take the common "Billie goat," which is as energetic a brush destroyer as he needs, and does not have to be shorn or need attention at kidding time, and can usually defend himself from dogs.

THE NIILKING GOAT.

Doubtless goats have been the companions of man for a longer time than cows and have befriended him for most of this time by sharing their milk with him. Therefore the milking' habit has been well fixed in certain types of goats. 
It is doubtless true that goats make better use of their food than cows, and turn more of it into milk. Therefore from the standpoint of economy goats make milk better and cheaper than cows. Furthermore, goats are almost never attacked with tuberculosis and their milk is said to have tonic properties of especial value to children. Then there is the fact that a goat is very much smaller than a cow, is easily sheltered, is tractable, requires but one-eighth as much food, and is in many ways better adapted to village or suburban life.

Taking these facts into consideration it is surprising that we have not had a larger development of the milch goat in America. There are two principal reasons: the incapacity of the average American for independence and self help, and his false pride that makes him fear ridicule if he adopts a practice that is followed by his poorer neighbors. Near many cities there are colonies of European emigrants who make more or less use of the goat as a milk-giving animal. Many a well-to-do suburbanite could follow this example with profit and gain, great comfort from the assurance of a supply of pure milk, produced under his own eye.

The writer has often seen cottagers in the old world employ goats for this purpose of milkgiving. Very often they would be tethered near the dwelling and children would bring them forage, clippings from the lawn, refuse from the table and surplus vegetables from the garden. Children would often do the milking, also, and the friendship between the gentle 
goat and the appreciative children was very real.

The amount of milk given by a well bred goat is extraordinary. From three to five quarts per day are not uncommon in Europe and the period of lactation is long. Some German authorities assert that the goat often yields ten times the weight of its body annually and that exceptional animals yield as much as eighteen times their weight.

It is a good goat of any breed that will yield two quarts per day for seven or eight months in the year.

The flavor of goats' milk is good, if the goats have good food. If they must subsist upon bitter and aromatic brush or upon onions, and refuse from the garden, there is danger of the flavors reacting on the milk. Milch goats when in use should be as carefully fed as dairy cows, given good wholesome sweet hay or clovers, alfalfa, or dried lawn clippings. They should have their ration of bran and oats, with a trifle of oilmeal if the best is sought. At times when they are not in milk they may be permitted to feast upon all sorts of brush and weeds that taste more palatable to them than to us.

As to the amount of feed required it is said that eight goats require about the same amount of food as one cow.

Milch goats need a comfortable, clean, dry house, well ventilated, for their winter's home. They need a good fence since they will climb and creep out whenever they have opportunity. They are quite often tied in stalls as cows are 
tied though it would seem better to give them clean, roomy pens. They should be milked regularly three times a day by the same person. They should be taken to a clean, odorless place to be milked. Previous to milking the udder and teats should be wiped quite clean. No tuberculous person should milk either goats or cows.

Milch goats are very prolific, having many pairs of twins and triplets. The Nubian goat, one of the best milking kinds, is said to have dropped eleven kids in one year. The period of gestation is about 155 days.

Just how to manage the kids when their mother's milk is needed for human consumption the writer does not see. Probably to wean them after the age of ten days, feeding them with the bottle a portion of their mother's milk and by substituting other foods, as bran with a litttle oilmeal in it, oats and good hay, or grass in summer would solve that problem.

It must be confessed that the interest in milch goats is mostly speculative at present in America, since there are so few here and the source of supply being Germany, Switzerland, France, and perhaps Malta or Italy, where animal diseases prevail. Besides, our regulations forbid the importation of goats or other cud-chewing animals. There is hope that some way may be opened to the importation of these animals and that an industry may spring up here. The best adapted to our climate would seem to be the goats of Switzerland and Germany, the 
THE ANGORA AND MILKING GOATS. 361

Toggenburger and Saanen breeds being especially desirable.

The Nubian goat is the greatest milker of them all, as well as the largest in size, but is not hardy in the colder parts of our country. Crosses of the Nubian on other goats are hardier and good milkers. It is remarkable that Africa should have given us this animal, the sole representative of its breeding that has come to us if we except the fat-tailed sheep of Tunis.

Doubtless these Nubian goats gave milk in the days of Joseph and Pharaoh. 



\section{INDEX.}

Age to discard ewes, 252, 253.

Alfalfa for pasture, 172 .

Alfalfa, how sheep may help start it, 171.

Alfalfa-fed lambs in Colorado, 264.

Alfalfa-fed lambs, quality of, 268 .

Alfalfa feeding in Kansas and Nebraska, 268.

American conditions described, 14.

Amount of feed needed to fatten lambs, 285.

Angora goats, 343.

origin of, 347 .

numbers of in Texas, 349 .

management, 351 .

"venison," 352.

as milkers, 35:.

period of gestation, 353 .

care at birth, 3 j4.

diseases of, 356 .

regions adapted to their growth, 357 .

Bales, Charles, successful feeder of sheep, 304.

Barn for ewes, 107.

for sheep feeding, 274 .

Beet pulp for feeding, 292.

Black-faced Highland sheep, 50.

Black-tops, Merinos, 25.

Bloat from alfalfa, 173 .

Bloating, prevention and treatment, 174, 175.

Bluestone for intestinal worms, 336 .

Breeding young ewes, 99.

Breeding on range, season of, 225 .

Brome grass, 172 .

Bronchitis, verminous, 323.

Buying stockers on the range, advantage of, 254 .

By-products of the feed-lot, 290 .

Cabbages as forage, 179.

Canadian field peas for lambs, 257

Castration, 148.

Cheviots, 49.

Colorado lamb feeding, 265.

Commissionmen, use of, 254 .

Corn for baby lambs, 13 .

for fattening sheep, 301 .

Cotswolds, 45.

Coyotes, troublesome on range, 226.

Creeps for lambs, 125 .

use of, 131.

Creosote for worms, 335 .

Crook, how to make and use, 109.

Cross-breeding, 63.

theory of, 65 .

on the range, 66 . 
Cross-breeding in Eastern pastures, 69. for market lambs, 67 . in the South. 70.

Dalrsmple Dr. W. H., of Louisiana, experiments of. $167,342$.

Delivery of lambs, signs of, 110 .

Dipping vat, 93.

for scab, 94.

in regular farm practice, 95 .

summary of practices, 97

on the range, 230.

feeding lambs, 241 .

at stock yards, 24\%.

es of sheep, 308

of feed-lot, 312 .

Dissection of dead sheep advisable. 314 .

Docking, 147.

Dorsets, 46.

where loated in United states, 49.

Dressing lambs for fancy market, $13 \overline{5}$.

England, large fiocks in. 13.

Ewes disown lambs, cause of, 105.

Ewes in stock yards, 249, 250.

Fall born lambs, 188 . how to get, 189

Fall feeding of ewes, 98 .

Fall treatment of ewe flock, 97 .

Fat ewes often barren, 178 .

Fattening sucking lambs, 128. sheep and lambs in winter. 238 weaned lambs in feed-lot, 255 .

Feeders, buying in stock yards, 243.

Feeding in the corn belt, $20 \%$

on grass, 141.

pure-bred stock lambs, 127.

stock lambs, 131.

the nursing ewe, 118

Feed racks, how made, 276 .

Feet, care of, 18\%.

Foot rot, foot scald, 183.

Fresh air for ewes necessary, 106.

Gains in feeding sheep, 304

Garget, induced by overfeeding, 12: treatment of, 316. instances of, 318.

Gasoline for worms, 337 .

Gestation, time of, 100.

Getting the flock home, 90.

Goats, profit from, $\mathbf{3 4 4}$.

milking, 357 .

milking, breeds of, 361 .

milking, care of. 359 .

use of in old world, 358 .

yield of in milk, 359 .

Grub in the head, 319 .

Hæmonchus contortus (stomach worm), 326.
Hampshires, 40 .

Harvesting peas in Colorado, 261

Hurdling in England, $1: 6$.

Inbreeding to fix type, 85 .

Incestuous breeding, 86 .

Indigestion, 309 . 
Infected pastures, treatment of, 341.

Invigoration of fresh blood, 86 .

Lambhood's troubles, 122.

Lambing tent, 186.

attention at, 113.

management to secure good, 104.

Lambs, late, management of, 138, 185.

feeding when very young, 124.

making ewe own, 116 .

reviving when chilled, 115 .

Leicesters, 42

born with too large frame, cause, 105.

Lincolns, 45.

Liver rot, $3: 0$.

Losses in feed lot, 289, 304.

Long wools, 42.

Management to insure healthy fiocks, 159.

Marking, 201.

Mating, 98.

Merinos, Delaine, American. Spanish, 25, 22.

Mexican lambs in feed lot, 214 .

Milking ewes, large, care of, 116.

Mutton breeds, 30 .

New England, freedom from parasitic enemies, 156.

New Mexican sheep, 206, 207.

New Mexico, management of flocks in, 209.

Nodular disease, $321,16 \%$.

Nomadic herds destroy forests and scatter scab, 219.

Northwestern plains country, 219.

Number of ewes for arable farms, 165.

Oats for grazing, 171 .

Origin of breeds, 21 .

Orphan lambs, making ewes own them, 118.

Outlook for sheep feeding, 297.

Oxfords, 41. hopeful, 235 .

Parasites, 152. on the ranges, 220 .

dangerous in shade of trees and fences, 145.

Pasturing fattening lambs, 290.

off corn and rape, 269.

system of to avoid worm infection, $16 t$.

Pea refuse for fattening, 297.

fed lambs, amount of gain per acre, $262,263$.

feeding in Colorado, 256 .

Pens for lambing ewes. 110 .

Persian-Merino ewes in California, 59.

Persian sheep, 55 .

Pregnant ewes, care of, 103

Profits in wether feeaing, 299.

Protein necessary in lamb feeding, 284

Pumpkins, 180.

Rambouillets, 26.

Ram, use of, 101.

management of, 100.

on the range, 223 .

for the range, where bred, 224 .

Ranching, protits of, 234 .

Range management, 210 .

diseases on, 213.

conditions, the trail herds, 215. 
Range management injured by nomadic herds, 216. herds in the mountains, 217. sheep, quality compared with Argentine sheep, 237.

Ransom, Dr. B. H., work on stomach worms, 326.

Rape, 178.

Ration for baby lambs, 13:. for mature sheep, 300 .

Recording pure-bred sheep, 205.

Regularity essential in feeding, 285 .

Restocking a farm, 72

Ripening feeding lambs, time required, 287.

Roots in the ration, 121.

Rye, vetches and clover, 168.

Salt on grass, 142

for fattening lambs, 279.

San Luis Valley (Colorado) methods, 258.

Scab, not necessary on the range, 231 .

Scotland, sheep on the Lammermoor hills, 5:.

Screenings, feeding, 271.

Self-feeders for screenings, 266 for old sheep, 303. use of on pasture and in barn, 291.

Self-feeding corn crib, 303.

Selecting a ram, 74 . ewes, 88 .

Shade in summer, 142. best if in barn, 144.

Shearing, early, 192.

art of, 193

fattening lambs, 286.

machines, 195.

on the range, 230.

twice a year, 198.

"Sheep Herders" a maligned lot, 23:. heroism of, 233 .

Shepherds' duties at lambing on range, 2:6.

Shipping dressed lambs, 137.

Shropshires, 37.

Silage for fattening lambs, 28; milling ewes, 120.

Sore eyes and mouths in lambs, 123.

Sore feet in Western lambs, 283.

Sore mouths in feeder lambs, 280 .

Southdowns, 35.

Southern mountain ewes, 71.

Soy beans for sheep, 133.

Spanish Merinos, 25.

Spring lambs, marketing, 146.

Starting the babies on feed, 131

lambs on corn, 283.

a healthful flock, 339 .

on feed, 278 .

Starvation, 314.

Stomach worms, treatment of, $155,3: 4,334$ preventing infection, $3: 9,331$.

Summer care and management, 151.

Tapeworms, 3:2.

Tattoo mark, 202.

Ticks and scab, 91.

Trough for young lambs, 131.

Tuberculosis, 315 .

Tunis breed, 55 . 
Turn sickness, 309, 310 .

Type, how evolved, 77,78 .

fixing, 82.

Ventilation of feeding barn, $\mathbf{2 7 5}$.

Vitality of prime importance, 87.

Vitality of range-burn lambs, $2: 25$.

Washing, 191, 192.

"Water belly," stoppage of urine, 313.

Water for baby lambs, 133.

in hurdling system, 166.

Watering troughs, how made, $2 i 6$.

Weaning, 149.

Wethers in feed-yard, 298.

Wheat bran for lambs, 280 .

Wind breaks for feed-yards, 302.

Wool, tying up. 195.

Worms, infection of, 160. 


\section{FARM BUILDINGS}

\section{THIS BOOK WILL BE FOUND VERY VALUABLE}

It does not take up the question of farm dwellings or residences, but in respect to general farm barns, horse barns, general cattle barns, dairy barns, sheep barns, hog pens, poultry houses, silos, feed racks, fencing, gates, efc., it is replete with interesting plans and descriptions.

\section{NOT THEORY, BUT ACTUAL CONSTRUCTION.}

\section{Every Plan Shown is in actual Use.}

A chapter on CEMENT CONSTRUCTION will be found of special value.

310 Pages. 513 Illustrations.

Price, \$2, Postpaid.

\section{Address SANDERS PUBLISHING CO.,} 358 Dearborn St., Chicago.

We always send books and mercbandise by prepaid express whenever it is possible for us to do so. If, therefore, books do not reach you through the mails, make inquiry of your express agent. 

WAY $23190 \%$ 

LIBRARY OF CONGRESS 